UNIVERSIDADE DE BRASÍLIA | UNB

FACULDADE DE ARQUITETURA E URBANISMO

Programa de Pós-graduação em Arquitetura e Urbanismo

OS LIMITES DA GENTRIFICAÇÃO

- NA VILA PLANALTO

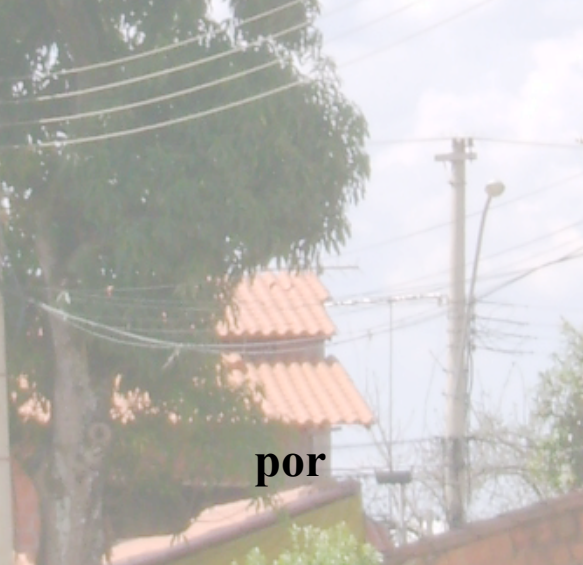

Matías Ocaranza Pacheco

Orientador: Prof. Dr. Frederico de Holanda

Co-orientador: Prof. Dr. Valério Medeiros

Dissertação de Mestrado | Projeto e Planejamento

\title{
Brasília
}

2015 


\section{OS LIMITES DA GENTRIFICAÇÃO NA VILA PLANALTO}

Dissertação apresentada ao Programa de Pós-graduação da Faculdade de Arquitetura e Urbanismo da Universidade de Brasília, como requisito parcial para a obtenção do título de Mestre em Arquitetura e Urbanismo.

Área de Concentração: Projeto e Planejamento Urbano e Regional.

Orientador: Prof. Dr. Frederico de Holanda Co-orientador: Prof. Dr. Valério Medeiros

Brasília 
Universidade de Brasília

Faculdade de Arquitetura e Urbanismo

Programa de Pós-graduação em Arquitetura e Urbanismo

Mestrando: Matías Enrique Ocaranza Pacheco

Dissertação: Os limites da gentrificação na Vila Planalto

Banca examinadora: Prof. Dr. Frederico Rosa Borges de Holanda, FAU-UnB (pdte.)

Profa. Dra. Christiane Machado Coêlho, SOL-UnB

Profa. Dra. Ana Elisabete de Almeida Medeiros, FAU-UnB

Prof. Dr. Benny Schavsberg, FAU-UnB (suplente)

Local e data da defesa: Brasília, 11 de setembro de 2015.

Ficha catalográfica elaborada pelo autor.

OCARANZA, Matías.

Os limites da gentrificação na Vila Planalto / Matías Enrique Ocaranza Pacheco. Brasília, 2015.

180 p., $297 \mathrm{~mm}$.

Orientador: Frederico Rosa Borges de Holanda.

Dissertação (mestrado) - Faculdade de Arquitetura e Urbanismo (FAU). Programa de Pós-graduação em Arquitetura e Urbanismo (PPG) Universidade de Brasília (UnB). Brasília.

1. Gentrificação. 2. Políticas públicas. 3. Limites. $4 . \quad$ Vila Planalto. 5. Brasília.

I. Universidade de Brasília. Faculdade de Arquitetura e Urbanismo. Programa de Pós-graduação em Arquitetura e Urbanismo.

II. Título. 
A Renata, companheira da minha vida e desta investigação. 


\section{AGRADECIMENTOS}

Agradeço ao Professor Doutor Frederico de Holanda por suas orientações críticas e exaustivas, fundamentais para o desenvolvimento da dissertação. Ademais, serei sempre grato por participar como estagiário docente em sua última disciplina ministrada na graduação da FAU-UnB, no curso Projeto Urbano I, durante o segundo semestre de 2013.

Agradeço ao Professor Doutor Valério Medeiros por suas certeiras contribuições, como co-orientador e durante as disciplinas do mestrado. Agradeço à Professora Doutora Ana Elisabete Medeiros que, de certa forma, também foi co-orientadora, fornecendo comentários nas bancas de qualificação e defesa da dissertação, como também na disciplina de Cidade Contemporânea.

À Professora Doutora Christiane Coêlho (SOL-UnB), agradeço sua presença na banca de defesa e suas valiosas observações. Agradeço à Professora Doutora Cristina Patriota (DANUnB) por suas contribuições nos aspectos do modo de vida, durante a realização da disciplina de Antropologia Urbana. Também, agradeço ao Professor Doutor Ernesto López (FAU-U. de Chile) pelo amplo aprendizado como seu ajudante no Chile e por me inspirar nos estudos sobre gentrificação.

Agradeço aos funcionários da secretaria do PPG-FAU, em especial a Junior e Diego pela ajuda sempre atenta. Expresso também meu agradecimento aos funcionários terceirizados que colaboram na segurança e limpeza na UnB.

Minha gratidão à CAPES (Coordenação de Aperfeiçoamento de Nível Superior) pela concessão de bolsa de estudo, ao DDS-UnB (Decanato de Desenvolvimento Social) pela bolsa de alimentação, e DPP-UnB (Decanato de Pesquisa e Pós-graduação) pelo apoio na participação em eventos científicos nacionais e internacionais. Agradeço também à Universidade de Brasília (UnB) e ao MEC (Ministério de Educação do Brasil) pela oportunidade de estudar no Brasil.

Agradeço a minha família e amigos pelo apoio constante, em especial a Renata minha esposa e a Lila e Nazário que nos receberam em sua casa aqui em Brasília.

Finalmente, agradeço a todas as pessoas que colaboraram neste trabalho, principalmente aos moradores da Vila Planalto que criam deste espaço um bairro. Especial reconhecimento aos vizinhos que abriram suas casas ou dedicaram um tempo na rua para conversar e responder minhas perguntas. 
SUMÁRIO

RESUMO

RESUMEN

8

ABSTRACT

9

INTRODUÇÃO

Caso de estudo

12

Perguntas 16

Hipóteses

17

Objetivos 18

Motivações

Teorias da Gentrificação, Sintaxe Espacial e Ecologia Humana.

Métodos de reconstrução do processo histórico, análise sintática do espaço e etnografia.

Técnicas de levantamento de dados, mapa axial e observação participante. 
$\begin{array}{ll}\text { História urbana } & 68\end{array}$

$\begin{array}{ll}\text { População e políticas urbanas } & 97\end{array}$

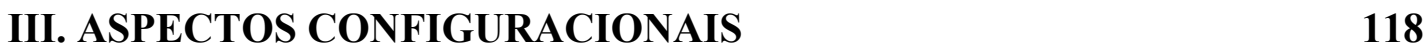

$\begin{array}{ll}\text { Transformações espaciais } & 118\end{array}$

$\begin{array}{ll}\text { Configuração espacial e dinâmica urbana } & 128\end{array}$

IV. ASPECTOS DO MODO DE VIDA 144

$\begin{array}{ll}\text { Cotidiano do bairro } & 144\end{array}$

Lugares e gentrificação simbólica $\quad 152$

$\begin{array}{lr}\text { CONCLUSÕES } & 160\end{array}$

$\begin{array}{ll}\text { Conclusões do caso de estudo } & 160\end{array}$

$\begin{array}{ll}\text { Conclusões gerais } & 167\end{array}$

$\begin{array}{ll}\text { Limitações e perspectivas futuras } & 171\end{array}$

$\begin{array}{lr}\text { BIBLIOGRAFIA } & 173\end{array}$

$\begin{array}{ll}\text { ANEXOS } & 181\end{array}$ 


\section{RESUMO}

A gentrificação na cidade contemporânea da América Latina é um processo de transformação urbana que provoca o deslocamento da população mais pobre. Diversos pesquisadores apontam a importância das políticas públicas na transformação dos bairros patrimoniais em lugares de consumo e especulação imobiliária, o que geraria segregação e a expulsão dos moradores de mais baixa renda. Para entender os fatores e as reações produzidas nesse processo, estuda-se o caso da Vila Planalto em Brasília. O bairro, tombado e fixado em 1988, está em constante transformação e valorização imobiliária. Propõe-se como hipótese que as políticas públicas implementadas no local são determinantes nas mudanças físicas e sociais, porém, as transformações introduzidas pelos próprios moradores têm criado limites ao processo de gentrificação. $\mathrm{O}$ caso de estudo é analisado sob três aspectos: Socioeconômicos, Configuracionais e Modo de vida; e com base em três teorias: Gentrificação, Sintaxe Espacial e Ecologia Humana. Observou-se que a aparente diversidade esconde uma polarizada estratificação social: barracos ao lado de mansões representam duas classes segregadas que, apesar da proximidade, não se relacionam. A popularização e a gentrificação são vizinhas e disputam o capital espacial da Vila Planalto. 


\section{RESUMEN}

La gentrificación en la ciudad contemporánea de América Latina es un proceso de transformación urbana que provoca el desplazamiento de la población más pobre. Diversos autores observan la importancia de las políticas públicas en la transformación de los barrios patrimoniales en lugares de consumo y especulación inmobiliaria, lo que generaría segregación y la expulsión de los habitantes de menor renta. Para entender los factores y las reacciones provocados en este proceso se estudia el caso de la Vila Planalto en Brasília. El barrio, declarado patrimonio en 1988, está en constante transformación y valorización inmobiliaria. Se propone como hipótesis que las políticas públicas implementadas en el lugar son determinantes en los cambios físicos y sociales, sin embargo, las transformaciones introducidas por los propios residentes han creado límites al proceso de gentrificación. El caso de estudio es analizado sobre tres aspectos: socioeconómicos, configuracionales y modo de vida; con base en tres teorías: gentrificación, sintaxis espacial y ecología humana. Se observó que la aparente diversidad esconde una polarizada estratificación social: casuchas al lado de mansiones representan dos clases segregadas que a pesar de la proximidad no se relacionan. La popularización y la gentrificación son vecinas y disputan el capital espacial de la Vila Planalto. 


\begin{abstract}
Gentrification in contemporary Latin American cities is a process of urban transformation that implies the displacement of people of lower incomes layers. Several authors note the importance of public policies for the transformations of heritage sites in places of consumption and real estate market, which would generate segregation and eviction of low-income inhabitants. To understand the factors and the reactions produced in the gentrifications process, the focus is on Vila Planalto, Brasília. The neighbourhood was declared a heritage site in 1988, and has gone through important changes since then. The hypothesis is: the public policies implemented in Vila Planalto are crucial to the physical and social changes involved; however, transformations introduced by residents have created limits to the process of gentrification. The case of study is carried out along three trends: socio-economic, configurational, and aspects related to modes of life. This is based on three theories: Gentrification, Space Syntax, and Human Ecology. It has been observed that the apparent diversity hides a polarized social stratification; shacks alongside mansions represent two segregated classes that despite the proximity are unrelated. A twin process of popularization and gentrification exists side by side and dispute the spatial capital in Vila Planalto.
\end{abstract}




\section{INTRODUÇÃO}

Em diversas cidades de América Latina e do mundo ocorrem processos de elitização do espaço urbano com expulsão dos habitantes e usuários de menor renda. Trata-se de um processo de transformação urbana em que a população original de bairros deteriorados ou empobrecidos é deslocada progressivamente para lugares mais afastados dos centros, sendo substituída por uma população de maior poder aquisitivo (LÓPEZ, 2008). Esse processo é definido como gentrificação, e inclui ciclos de desvalorização (abandono e deterioro) e de valorização (investimentos públicos e privados) como estratégia de apropriação do capital espacial.

O capital espacial é definido como o conjunto de recursos acumulados por um ator social que lhe permitem usar estrategicamente a dimensão espacial e tirar vantagens na sociedade. O capital espacial é um bem social acumulável e utilizável para produzir outros bens sociais. O conceito que parte da denominação de capital cultural de Bourdieu (1990) é reinterpretada por Lévy (2000) reconhecendo a natureza política do espaço e principalmente do espaço central das cidades. Para Lévy (2000), constitui um recurso fundamentado na capacidade de manipular a dimensão espacial de um bem seja material ou imaterial - e de valorizar-lhe em outro tipo de recurso (político, econômico, social ou simbólico) (HOFFMANN, 2002).

Este trabalho estuda a gentrificação compreendida como a transformação de um bairro pobre urbano ou de nível de renda baixo em um bairro de maior nível de renda, de classe média ou média alta residencial ou comercial. Essa mudança socioeconômica produz deslocamento, entendido como o fenômeno que ocorre quando um grupo economicamente mais frágil muda-se para locais menos valorizados e é substituído por outro mais forte em um determinado local ou território.

A gentrificação é muito mais que um processo de mudanças na estrutura social de um setor, ela também transforma diferentes aspectos da vida cotidiana, principalmente da população menos favorecida, que é expulsa (JANOSCHKA; SEQUERA, 2014). Com a gentrificação não só se transformam os espaços patrimoniais em lugares de consumo, também se reinterpretam os sentidos desses espaços enobrecidos (LEITE, 2007). Nesse aspecto, cada caso de estudo é um processo diferente que requer uma 
reaproximação crítica dos conceitos e de categorias analíticas flexíveis para sua aplicação.

Inzulza (2012) reivindica o estudo de casos no contexto latino-americano e propõe o conceito de latino-gentrification, ligando o processo a padrões mais locais dentro das estratégias globais de revitalização urbana. Na mesma direção, Janoschka e Sequera (2014) discutem a descentralização do debate do contexto europeu, incorporando as especificidades de cada local, e reconhecem três elementos-chave: 1) o papel da administração pública na criação e articulação de novos mercados imobiliários; 2) a dimensão simbólica por meio da reapropriação do patrimônio arquitetônico e cultural; e 3) a violência aplicada na formalização de cidades e economias principalmente informais e nas formas de deslocamento (JANOSCHKA; SEQUERA, 2014).

López (2015) ressalta que a gentrificação das cidades latino-americanas denega o direito dos pobres urbanos de ocupar espaços centrais e pericentrais. Com a revisão de diversos estudos, o autor identifica um consenso na definição de gentrificação como um processo de expulsão de um espaço urbano central de usuários de menor status socioeconômico ou cultural, promovido por investimentos econômicos e públicos que procuram a restruturação física e social do local.

A ênfase atual em políticas públicas com vistas ao crescimento de mercados imobiliários, com escassa regulação e sem cuidar as possíveis externalidades negativas, contribui para formar cidades com pouco sustento político real e situações de conflito socioambiental (LOPEZ, et al., 2012). Como resposta, os estudos sobre gentrificação experimentam um aumento nos últimos anos, mas a interpretação das causas e dos efeitos ainda provoca polêmica. A gentrificação enquanto teoria, principalmente na América Latina, é um tema em desenvolvimento e sua construção representa um desafio para os enfoques tradicionais, para as políticas urbanas e para os teóricos do urbanismo. Assim, a gentrificação se configura como um problema político, já que as mudanças forçadas de classe nas zonas centrais acentuam os problemas de polarização sociais já existentes nas cidades (LÓPEZ, 2015).

Os processos de gentrificação são uma estratégia global de produção do espaço urbano, principalmente no tocante às tentativas de revitalização das zonas centrais das cidades, como demonstram os trabalhos de Lees et al. (2008) e Smith (1987, 2006), entre outros. Por esse motivo, é um processo interessante de pesquisar e de abordar 
desde a perspectiva de um urbanismo crítico (BRENNER, 2009; MARCUSE, 2009). A teoria da gentrificação questiona o papel do Estado e do mercado nas transformações urbanas, ressaltando a importância de uma visão crítica da realidade. Nessa direção, Marcuse (2009) e Brenner (2009) convidam ao reestabelecimento acadêmico de um urbanismo abertamente crítico no âmbito político, e destacam quatro condições necessárias para sua formação: primeiro, a função da teoria na análise urbana é estratégica. Segundo, o urbanismo deve ser reflexivo, pois confronta as lógicas de desenvolvimento urbano capitalista com suas próprias contradições: desigualdade, exclusão e sobreacumulação do solo. Terceiro, o urbanismo deve desligar-se do pensamento tecnocrático instrumental e configurar suas próprias orientações práticas/políticas de desenvolvimento social urbano. Quarto, o urbanismo crítico não somente deve investigar as formas de dominação do modo de produção capitalista, mas também encontrar as possibilidades de emancipação que são produzidas e, ao mesmo tempo, subjugadas por esse sistema.

Dentro de um enfoque do urbanismo crítico, analisamos os fatores que influenciam as transformações urbanas geradoras de deslocamento social e os possíveis limites que a sociedade cria para resistir às pressões do mercado. Um fator relevante são as políticas oficiais que intervêm no patrimônio cultural das cidades. $\mathrm{O}$ principal problema que enfrentam alguns bairros patrimoniais são as políticas de revitalização urbana - também chamada de "renovação" ou "requalificação" (LEITE, 2007) — que acabam expulsando ou segregando os moradores e usuários de baixa renda para abrir espaço ao consumo através de atividades como o turismo e lazer.

\section{Caso de estudo}

Esta dissertação analisa o caso da Vila Planalto em Brasília, um exemplo paradigmático da relação entre arquitetura e segregação, e apresenta uma análise das transformações urbanas locais e sua relação com a gentrificação no contexto latinoamericano e global. A Vila foi um antigo acampamento de obras que, após seu tombamento, intensificou o processo de transformação urbana, perdendo muitas das suas características patrimoniais, e que atualmente enfrenta uma forte valorização imobiliária.

O bairro está localizado a $1.500 \mathrm{~m}$ da Praça dos Três Poderes (Figura 1). A Vila Planalto se origina em 1956 como um acampamento de obras provisório das construtoras dos principais edifícios de Brasília. Depois de um processo de resistência, 
em 1988, o bairro consegue sua permanência ao ser tombado como Patrimônio Histórico do Distrito Federal ${ }^{1}$, e os moradores receberam uma concessão de uso dos lotes. A partir desse momento as transformações físicas e sociais se intensificaram e o bairro perdeu as características que levaram ao seu tombamento, bem como alguns de seus moradores originais. Em 2014, um pequeno grupo de pioneiros recebeu os primeiros títulos de suas propriedades, o que poderia representar um mecanismo de regularização imobiliária para um mercado já existente.

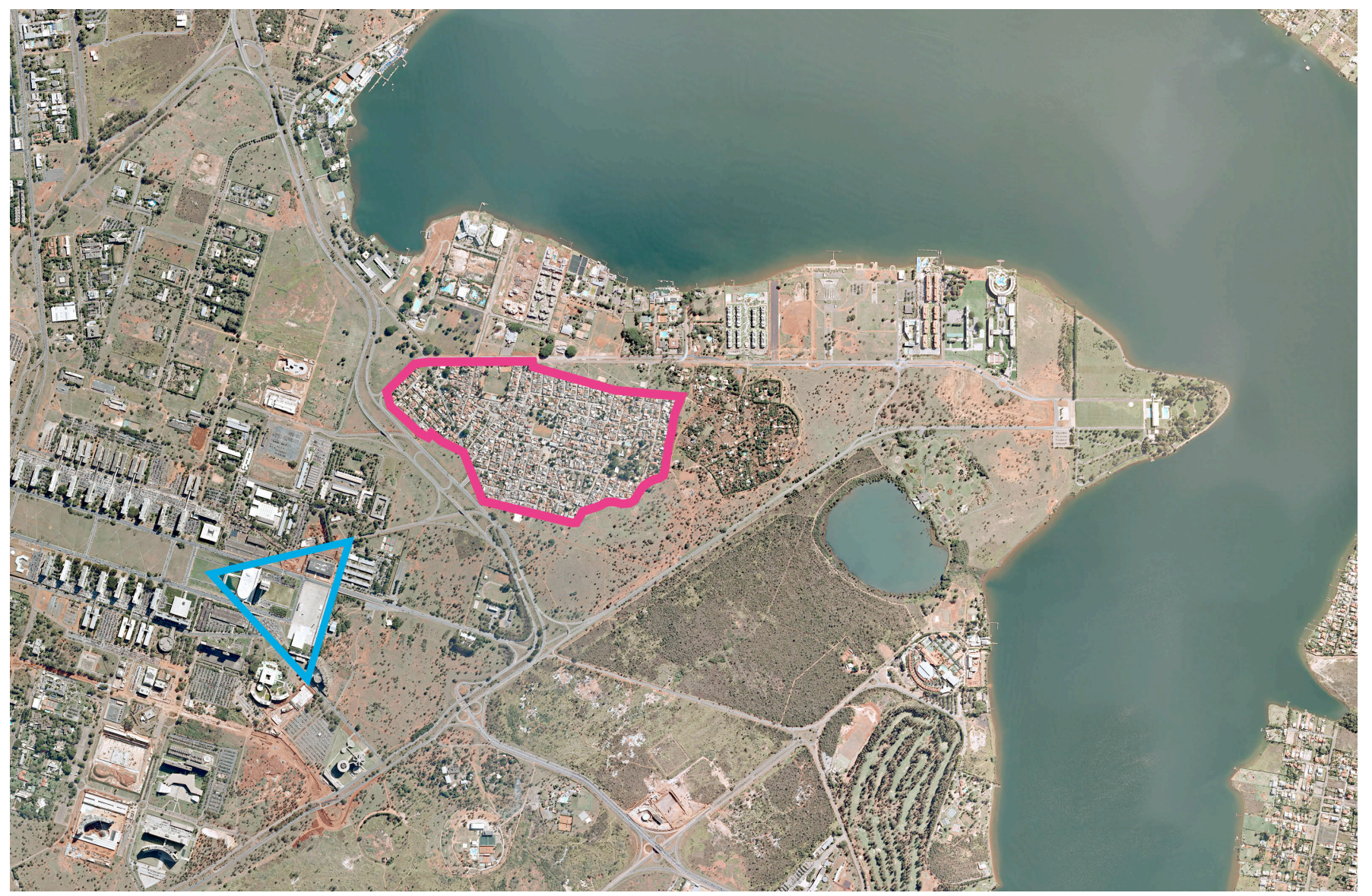

Figura 1: Polígono demarcando a Vila Planalto (magenta) e a Praça dos Três Poderes (cyan) em Brasília.

Fonte: Elaboração própria com base em levantamento empresa Topocart (Terracap, 2013).

No período em que foi acampamento de obras, a Vila Planalto abrigou operários, engenheiros, empresários da construção de Brasília e políticos que passaram esporadicamente pelo lugar até a inauguração da nova capital. Na atualidade, é um bairro que resulta da união de remanescentes de cinco acampamentos das antigas empreiteiras: 1) Tamboril, 2) DFL (Departamento de Força e Luz), 3) Pacheco

\footnotetext{
${ }^{1}$ No dia 21 de abril de 1988, a Vila Planalto foi tombada e fixada pelo Departamento do Patrimônio Histórico e Artístico do Distrito Federal - DePHA - e pelo Instituto Patrimônio Histórico e Artístico Nacional - IPHAN -, com os Decretos $\mathrm{N}^{\circ} 11.079 / 88$ e $\mathrm{N}^{\circ} 11.080 / 88$ (Figura 2).
} 
Fernandes, 4) Rabelo e 5) nove lotes do acampamento EBE (Empresa Brasileira de Engenharia) (Figura 2), que construíram obras como o Palácio da Alvorada, a Praça dos Três Poderes, o Palácio do Planalto e o Supremo Tribunal Federal.

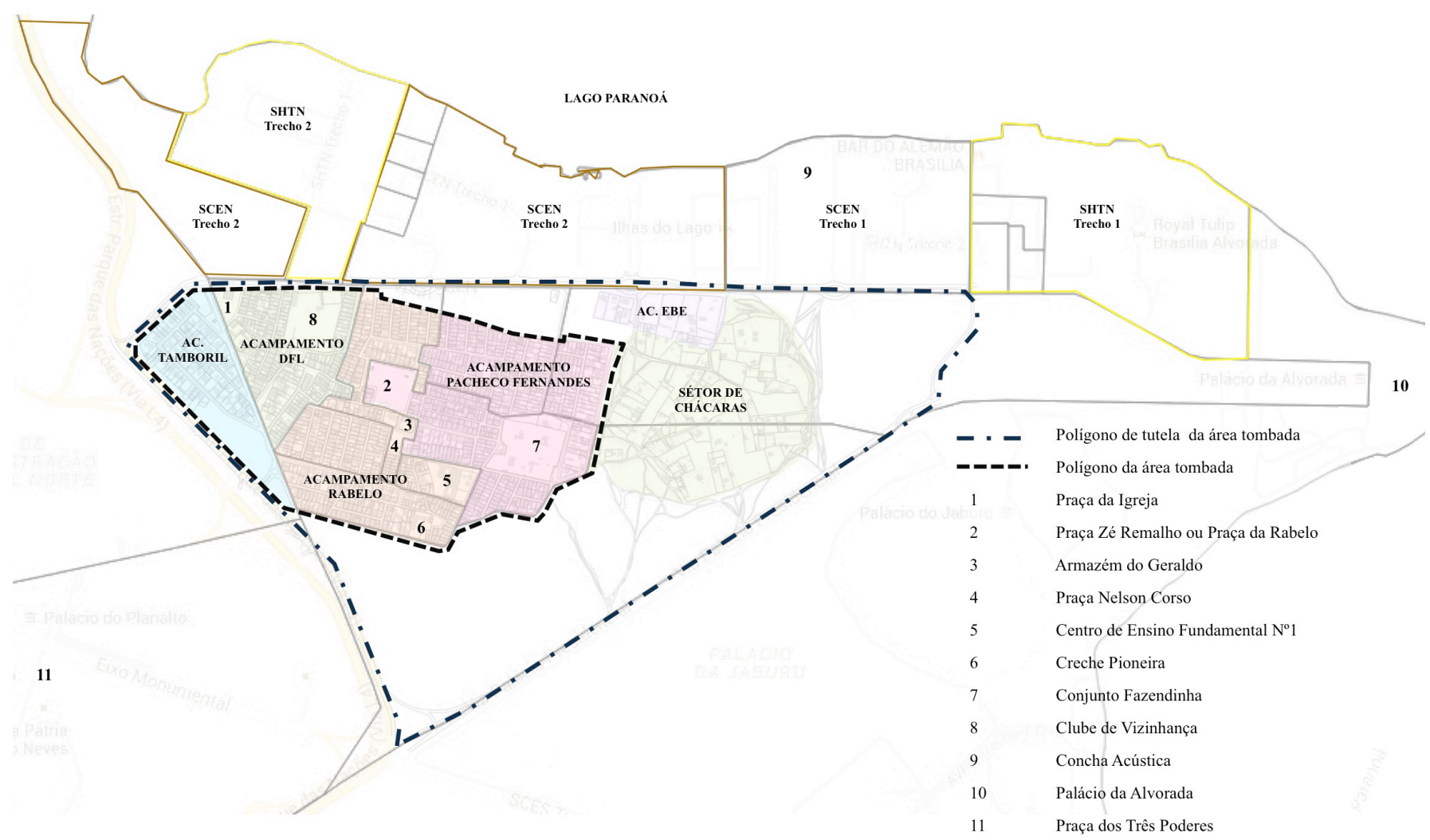

Figura 2: Mapa da Vila Planalto e entorno indicando os polígonos de tutela e da área tombada em 1988, cinco dos acampamentos remanescentes e pontos de interesse. Fonte: Elaboração própria.

Fatores como o tombamento (conjunto de leis que protege algumas características físicas), o estado da propriedade do solo (impossibilidade de venda formal), as restrições impostas pela "força da arquitetura" (HOLANDA, 2013), bem como certos mecanismos utilizados pelos habitantes para permanecer em seu espaço (ZARUR, 1991) representam, até certo ponto, um freio aos processos de substituição dos moradores de baixa renda e impõem potenciais limitações ao processo de elitização do bairro. Ainda assim, e apesar de coexistirem lado a lado barracos e mansões, esses fatores não impedem que a cada dia o bairro se torne um setor de classe média, devido 
às transformações edilícias e principalmente pela elitização dos usos e usuários em determinados setores. Isso poderia ser entendido como gentrificação.

O lugar tem grande diversidade urbana, com lotes, casas, quarteirões, ruas e espaços públicos que variam em dimensões, formas, características, usos e apropriações. Existem lotes maiores, que permitem a construção de garagens ou adaptações nas vivendas, respondendo às expectativas da classe média, mas esses lotes não são a maioria. Há, na atualidade, uma ampla oferta de aluguéis de casas, apartamentos e kitchenettes, além da venda de lotes e casas. Diversos restaurantes, bares, hotéis e albergues atraem novos usuários para o bairro todos os dias. Além disso, está em andamento a regularização dos lotes, que entregará as escrituras por: 1) doação (a pioneiros e filhos de pioneiros fixados em 1988 e 1996); 2) venda direta (para ocupantes não cadastrados) e licitação (para ocupantes ou abertas ao público para lotes vazios).

Ante este processo, visualiza-se uma nova fase de potenciais transformações na configuração espacial, na estrutura socioeconômica e no modo de vida dos habitantes. $\mathrm{O}$ fim da impossibilidade de venda formal dos lotes e a consequente abertura à comercialização poderiam produzir a troca definitiva da população mais pobre por outra de maior renda. Assim, a principal questão que a dissertação pretende responder é: existem limites no processo de gentrificação na Vila Planalto?

Segundo Holanda (2013), a grande diversidade espacial se relaciona com uma grande diversidade social, onde a configuração espacial é fortemente responsável pela estabilidade da população por mais de cinquenta anos. Assim, cinco décadas depois de inaugurada a cidade, forças de mercado não foram capazes de expulsar todos os moradores de baixo poder aquisitivo, pelo contrário: trabalhadores manuais continuam alugando residências e mudando-se para o local. No entanto, o caráter pitoresco e a localização próxima ao Plano Piloto elevam o preço de venda e aluguel das propriedades $^{2}$ e aumentam a presença de restaurantes e bares destinados a usuários externos. Com isso, muitos habitantes originais emigram, vendendo ou alugando suas casas, o que têm provocado a substituição de uma parte dos moradores mais antigos e a troca de comércios populares por negócios gourmet, gerando a exclusão dos moradores e usuários de menor renda.

2 http://www.correiobraziliense.com.br/app/noticia/cidades/2011/11/14/interna_cidadesdf,278319/vilaplanalto-esta-sendo-desfigurada-pela-especulacao-imobiliaria.shtml. Revisado em: 23.05.2015. 


\section{Perguntas de investigação}

Para entender o processo de gentrificação no caso de estudo, analisamos as transformações urbanas do bairro a partir de duas perguntas principais. A pergunta inicial da dissertação é se existem limites ao processo na Vila Planalto. A segunda pergunta é sobre a particularidade do bairro, considerado como uma exceção dentro do "espaço de exceção" 3 da capital brasileira. A pergunta é: em que medida a gentrificação e seus limites são produto das relações locais ou globais que afetam a cidade?

O principal foco da dissertação é o estudo das relações entre espaço $x$ sociedade $^{4}$, por este motivo o caso de estudo é analisado sob três aspectos: configuracionais (morfológicos), socioeconômicas (população e políticas públicas) e modo de vida (cotidiano). Esses aspectos derivam da proposta de Holanda (2002) para o desenvolvimento da análise sintática do espaço em três níveis: padrões espaciais (estrutura espacial), sistemas de encontros (práticas sociais) e categorias socioeconômicas a-espaciais (características culturais, econômicas e sociais) (RIBEIRO, 2013).

Três perguntas secundárias derivam desses aspectos: 1) Existe relação entre as políticas públicas e as mudanças socioeconômicas e físicas do espaço urbano?; 2) De que modo a configuração espacial pode expressar os processo da dinâmica urbana?; 3) Quais são as características do processo de gentrificação na Vila Planalto e como ela afeta a vida cotidiana do bairro (história, causas, consequências, resistências)?

\footnotetext{
3 (HOLANDA, 2002).

${ }^{4}$ (HOLANDA, 2010a, 2013)
} 


\section{Hipóteses}

Com base nas perguntas formuladas anteriormente, estabelecemos como primeira hipótese que existe, na Vila Planalto, um processo de gentrificação com características locais, porém, dentro de um contexto de políticas urbanas globais. Partimos da premissa de que o bairro experimenta um processo de elitização de seu espaço, mas com limites, que decorrem do conflito entre a legislação e as transformações introduzidas pelos próprios moradores.

Uma segunda hipótese da pesquisa é a seguinte: as políticas públicas que intervêm no patrimônio cultural transformam o espaço urbano em lugar de consumo e especulação imobiliária, segregando e expulsando os moradores de baixa renda. Desta forma, o processo de gentrificação é acompanhado por transformações na configuração urbana (relações forma-espaço), na estrutura socioeconômica do bairro (características culturais e sociais), e no modo de vida de seus habitantes (sistema de convivência e relações sociais).

Esses aspectos dividem a pesquisa em três hipóteses subjacentes à análise da Vila Planalto: 1) Entende-se a configuração como a relação entre a forma e o espaço, ou seja, como se organizam e interagem os cheios (edifícios e barreiras) e os vazios (espaços potencialmente públicos) no espaço urbano, em outras palavras, como um conjunto de elementos que se articulam entre si (MEDEIROS, 2006; HOLANDA, 2013). Entendemos que existe uma relação entre o processo de mudanças na estrutura social e as transformações na configuração do bairro.

2) As transformações socioeconômicas nos moradores e nos usuários do bairro incentivadas por políticas públicas que promovem o consumo cultural — produzem segregação e exclusão socioespacial, o que alguns autores identificam como gentrificação simbólica (INZULZA, 2012; JANOSCHKA; SEQUERA; SALINAS, 2013; JANOSCHKA; SEQUERA, 2014).

3) Finalmente, entendemos que esse processo de gentrificação é acompanhado por uma mudança no cotidiano dos habitantes do bairro, ou seja, o modo de vida dos moradores originais ou mais antigos está sendo substituído pelo cotidiano dos novos moradores ou sujeito gentrificador. Apesar do enobrecimento, os espaços urbanos não se esvaziariam de pessoas nem de sentidos e novos sujeitos se apropriam diariamente dos lugares, qualificando esses espaços como potencialmente públicos (LEITE, 2007). 


\section{Objetivos}

Esta dissertação tem por objetivo principal aventurar-se a conhecer e explicar o processo de transformação urbana na Vila Planalto, incorporando um caso de estudo para a análise da gentrificação na América Latina e para contribuir à discussão sobre os efeitos das transformações urbanas na cidade. Outro objetivo é observar as diferentes práticas sociais que acontecem nos espaços públicos da Vila Planalto para analisar as relações entre a forma física e a sociedade. Dentro do estudo da gentrificação, incorpora-se um enfoque configuracional e a aplicação de métodos da antropologia urbana para compreender os movimentos, as pressões e os conflitos existentes que poderiam gerar deslocamentos ou formas de expulsão.

Pretende-se contribuir para o entendimento da sociedade desde o prisma do espaço (HILLIER; NETTO, 2001) e também para a compreensão do espaço sob o prisma da sociedade. A dissertação tenta reposicionar as pessoas no centro dos estudos urbanos, enfatizando a relação dos habitantes com seu espaço. A possibilidade de morar na Vila Planalto durante o período final de pesquisa permitiu a observação participante e o convívio com residentes e visitantes, como também a possibilidade de percorrer o bairro diariamente e a pé. A tentativa de humanizar o urbanismo significa a realização de trabalho de campo com observação direta e preocupação com os problemas dos moradores. O que Carlos Nelson Ferreira dos Santos descreve como uma arquitetura "de pé no chão" 5 , ou um urbanismo à escala humana, que estuda na cidade os padrões espaciais, as inter-relações sociais e seus significados (SANTOS, 1980).

A partir das intenções gerais desdobram-se outros quatro objetivos: 1) analisar o processo de desenvolvimento urbano do bairro, sob a ótica das teorias da Gentrificação, da Sintaxe Espacial e da Ecologia Humana; 2) entender as mudanças urbanas da Vila Planalto desde o ponto de vista da relação entre estrutura espacial e a sociedade que a produz; 3) visualizar os tipos de pressões por deslocamentos ou formas de expulsão que podem acontecer no bairro, assim como as respostas da sociedade a essas pressões; 4) o último objetivo específico é a sistematização de informações qualitativas e quantitativas que articulem a dimensão social e espacial, especificamente, instrumentos de levantamento de dados, tais como: enquete domiciliar, entrevistas, cadastros in loco, e observação direta, que serão descritos com maior precisão nos aspectos metodológicos.

\footnotetext{
${ }^{5}$ (VELHO, 1980, p.42).
} 
Os objetivos específicos e de caráter operacional se descrevem na seguinte tabela segundo as perguntas de investigação:

Quadro 1: Perguntas de pesquisa e seus objetivos específicos.

\begin{tabular}{|c|c|}
\hline Pergunta de pesquisa & Objetivo específico \\
\hline $\begin{array}{l}\text { 1. Existem limites no processo de gentrificação } \\
\text { da Vila Planalto? }\end{array}$ & $\begin{array}{l}\text { Identificar e caracterizar o potencial impacto das } \\
\text { transformações urbanas e as respostas produzidas pelas } \\
\text { práticas sociais. }\end{array}$ \\
\hline $\begin{array}{l}\text { 2. Em que medida a gentrificação da Vila } \\
\text { Planalto é resultado das relações globais ou } \\
\text { locais que atuam na cidade? }\end{array}$ & $\begin{array}{l}\text { Identificar e caracterizar os mecanismos utilizados pelos } \\
\text { agentes públicos e privados no processo de transformação } \\
\text { urbana. }\end{array}$ \\
\hline $\begin{array}{l}\text { 3. Qual é a contribuição das políticas públicas } \\
\text { implementadas no bairro nas mudanças físicas e } \\
\text { socioeconômicas? }\end{array}$ & $\begin{array}{l}\text { Quantificar e analisar os efeitos das normativas e legislações } \\
\text { nas mudanças espaciais e sociais da Vila Planalto. } \\
\text { Sistematizar e avaliar as iniciativas históricas que o poder } \\
\text { público tem desenvolvido na cidade e sua correlação com } \\
\text { indicadores sociais e com as transformações na forma } \\
\text { construída. }\end{array}$ \\
\hline $\begin{array}{l}\text { 4. De que modo a configuração espacial } \\
\text { expressa os processos da dinâmica urbana? }\end{array}$ & $\begin{array}{l}\text { Quantificar e analisar os efeitos da configuração espacial na } \\
\text { distribuição dos usos de solo potenciais geradores de } \\
\text { dinâmica urbana. Utilizar ferramentas da Sintaxe Espacial } \\
\text { para medir as transformações na malha viária e sua } \\
\text { correlação com a dinâmica urbana do bairro. }\end{array}$ \\
\hline $\begin{array}{l}\text { 5. Quais são as características do processo de } \\
\text { gentrificação e como se transformam os } \\
\text { cotidianos do bairro? }\end{array}$ & $\begin{array}{l}\text { Identificar e caracterizar o processo de gentrificação do } \\
\text { bairro do ponto de vista das praticas sociais: modos de } \\
\text { resistências e apropriações do espaço. Utilizar ferramentas } \\
\text { da antropologia urbana para sistematizar e analisar as } \\
\text { relações sociais que acontecem no espaço público. }\end{array}$ \\
\hline
\end{tabular}




\section{Motivações}

Esta é uma dissertação sobre a gentrificação na Vila Planalto, bairro onde moro desde setembro de 2014, onde acontece minha vida cotidiana e onde faço a pesquisa. Em 2007, conheci a história da Vila Planalto. Durante minha primeira visita a Brasília, comprei o livro "Brasília: Moradia e Exclusão" (PAVIANI, 1996) com o artigo, "Vila Planalto: um caso de resistência popular" de Sandra Zarur. Só conheci o bairro, pessoalmente, em 2009, durante uma segunda visita a Brasília. Nesse ano a Vila Planalto foi motivo de estudo durante minha graduação na Universidad de Chile. A pesquisa focava a participação como mecanismo de resistência pelo direito à moradia. Nesse período as transformações urbanas provocadas pela pressão imobiliária já apontavam para uma elitização do bairro. Estava observando um caso de gentrificação sem antes ter ouvido essa palavra. Depois de conhecer mais sobre a teoria explicativa deste fenômeno urbano, quis estudar a Vila Planalto como um caso de gentrificação. Esta é a principal motivação para a escolha do tema de pesquisa.

Outra motivação é o estudo de bairros residenciais e suas transformações urbanas. Minha trajetória profissional coincide com o trabalho em bairros predominantemente residenciais como a Vila Planalto. No Chile, tive a possibilidade de trabalhar em programas de melhoramento urbano em bairros populares, no âmbito acadêmico e governamental. O trabalho direto com a população e organizações territoriais me levaram a pensar sobre a importância de um planejamento urbano participativo que promova a construção coletiva do espaço em prol do direito à cidade.

O direito à cidade definido por Lefebvre (1969) corresponde ao direito dos habitantes urbanos a viver em cidades onde suas necessidades e desejos sejam respondidos. Harvey (2012) agrega que não é só acesso, também é o direito de imaginar e transformar a cidade e a vida urbana. Com base nos dois autores, entendo o direito à cidade como o direito dos habitantes a pensar, decidir, construir e transformar a cidade e o ritmo de vida urbano de maneira coletiva. A gentrificação está dentro da discussão do direito à cidade, na medida em que esse direito significa a luta pelo espaço bem localizado para as populações mais pobres.

Esta pesquisa analisa o problema e seu caso de estudo sob três aspectos: 1) socioeconômicos, 2) configuracionais, e 3) modo de vida. Analisamos os aspectos com base em três vertentes teóricas correlatas, com as quais me identifico, disciplinas no 
campo da arquitetura e pertinentes no estudo das transformações urbanas. As teorias são: a) Gentrificação, b) Sintaxe Espacial, e c) Ecologia Humana.

Seguindo o problema e os aspectos analíticos propostos, a dissertação se divide em seis partes: 1) Introdução, descreve o problema da gentrificação e nosso caso de estudo, além dos objetivos e motivações de pesquisa. 2) Aspectos teóricos, metodológicos e técnicos: apresenta uma revisão bibliográfica das três correntes teóricas que fornecem os conceitos para a análise, e também explica a metodologia e as ferramentas técnicas derivadas de cada teoria. 3) Aspectos socioeconômicos, resultado da análise socioeconômica do bairro que contempla: a história das transformações sociais do bairro, uma abordagem sobre os potenciais espaços segregados ou gentrificados, e as políticas publicas implementadas na Vila Planalto. 4) Aspectos configuracionais, aborda a análise das relações entre a forma e o espaço do bairro; compreende as transformações espaciais sofridas ao longo da história, a configuração espacial atual e a dinâmica urbana do bairro. 5) Aspectos do modo de vida, aborda os resultados da análise etnográfica (metodologia da antropologia urbana), representando os atores envolvidos no processo de gentrificação, o cotidiano dos moradores e os potenciais lugares ou espaços públicos. 6) Conclusões, descreve as reflexões finais e possíveis respostas para as perguntas de pesquisa, e também revisa os objetivos e propõe perspectivas futuras. 


\section{ASPECTOS TÉORICOS, METODOLÓGICOS E TÉCNICOS}

Uma dissertação de mestrado, como trabalho acadêmico, deve produzir conhecimento científico, resultado de um processo racional onde os pressupostos são examinados de maneira crítica. Hillier e Hanson (1984) sugerem que existem dois tipos de conhecimento: o conhecimento social ou irreflexivo (cotidiano, regras dadas) e o conhecimento científico ou analítico, que procura estabelecer teorias reflexivas que expliquem os fenômenos que ocorrem no mundo. Desdobrando estas categorias, Holanda (2002) sugere que existem dois níveis de conhecimento para entender a realidade. Um primeiro nível inconsciente de conhecimento (representações da realidade), que é objetivo e usado cotidianamente; e um segundo nível de consciência discursiva (realidade objetiva), que busca explicar o mundo espaço-temporal em três níveis discursivos: 1) discurso especulativo, 2) discurso empírico, e 3) discurso científico.

Holanda (2013) define o discurso científico como aquele que "procura revelar a natureza profunda dos fenômenos" (HOLANDA, 2013, p. 274). Assim, a tarefa dos cientistas - dentro deles os arquitetos - seria interpretar as estruturas e leis subjacentes aos fenômenos estudados. Para Holanda (2010a), os estudos de arquitetura e urbanismo devem estar no nível do discurso científico. $\mathrm{O}$ autor afirma que entender a arquitetura como disciplina científica significa fortalecer a idéia de interdisciplinaridade, para assim responder a questões relacionadas aos lugares produzidos ou apropriados pelas pessoas. A arquitetura e o urbanismo - como disciplinas das ciências humanas - estudam as relações entre os lugares e as pessoas, e focam os lugares com olhar disciplinado, buscando entender suas propriedades (HOLANDA, 2013). Para investigar as expectativas sociais existentes por trás da produção do espaço arquitetônico, o autor sugere entender a realidade empírica do lugar, como um sistema de barreiras e permeabilidades que implicam encontros e esquivanças (HOLANDA, 2010a).

Para que o estudo da arquitetura esteja no nível do conhecimento analítico deve fundar-se no método científico, sendo necessário identificar as operações mentais e técnicas que possibilitem sua verificação. Gil (2008) define o método científico como o "conjunto de procedimento intelectual e técnicos adotados para se atingir o conhecimento" (GIL, 2008, p. 27). O autor considera o método como um caminho determinado para chegar à comprovação. Nesse sentido, Humberto Giannini (2013) 
acrescenta que, além de ser um caminho, o método pergunta pelos princípios que se acham nas profundidades, levando o investigador a trabalhar num nível análogo ao do arqueólogo. Giannini (2013) interpreta que a raiz etimológica da palavra método (metá: além de; hodós: caminho) estaria relacionada com a palavra arqué, que significa princípio ou fundamento, assim o método seria o caminho que pergunta pelos princípios do subsolo da realidade (GIANNINI, 2013).

Esta pesquisa utiliza principalmente o método hipotético dedutivo e procedimentos observacionais. Neste método, que vai do particular para o geral, as premissas são constatadas a partir da observação de casos concretos (GIL, 2008). A indução como mecanismo da pesquisa social permite inferir conclusões gerais de proposições particulares, como por exemplo, um caso de estudo empírico, com o qual é possível explicar e verificar os fenômenos analisados (TRUJILLO, 1982).

Para esta dissertação de mestrado, analiso empiricamente um caso de estudo específico e utilizo o método indutivo com o fim de descobrir as leis e as relações desse caso. O estudo de só um caso se justifica quando as questões básicas sobre a realidade são o como e o porquê, quando nenhum controle contextual é possível, e quando o objeto da investigação é um evento contemporâneo (LÓPEZ, 2009).

Esta parte da dissertação revisa os aspectos teóricos, metodológicos e técnicos. O trabalho, que faz parte do estudo das relações espaço $x$ sociedade (HOLANDA, 2002, 2010b, 2010c, 2013), analisa o processo de gentrificação da Vila Planalto, quanto a suas características sociais, espaciais e do modo de vida. Para entender o processo de transformação urbana utilizaremos a Gentrificação como o principal arcabouço teórico de análise, complementando-a com a Sintaxe Espacial e a Ecologia Humana. Com base na estrutura proposta por Holanda (2013) cada teoria é composta por: itens de conhecimento, formulações teóricas, campo de reflexão e axiomas. O método relativo a cada teoria também é subdividido em: conceitos, categorias, atributos e relações. Para finalizar as técnicas correspondentes são explicadas desde suas ferramentas, seus procedimentos, suas representações e informações. 


\section{Teoria da Gentrificação}

As pesquisas sobre processos de gentrificação são extensas, de diversos autores e dia a dia despertam mais interesse na América latina. Os autores mais referenciados têm um olhar global na tentativa de construir uma teoria que explique o fenômeno urbano (SMITH, 1979, 1995; CLARK, 2005; LEES; SLATER; WYLY, 2008; SLATER, 2011). Outras investigações abordam uma perspectiva histórica e social que focaliza os aspectos econômicos, principalmente, a perda da renda potencial do solo (SMITH, 1987, 2012a; LÓPEZ, 2008, 2010). Um grupo recente de publicações também se concentra nos efeitos simbólicos da elitização do espaço centrais (VIERIA, 2006; LEITE, 2007; RODRIGUES，2010; SCHLACK; MOSCIARO，2012; SEQUERA, 2013; JANOSCHKA; SEQUERA, 2014). Outro pequeno grupo de pesquisas utiliza informações sobre a configuração espacial e sua relação com processos de gentrificação (ZDRAHALOVA, 2000; DALTON, 2006; MATTHEWS; TURNBULL, 2007; CHIARADIA et al., 2009). Mas são quase inexistentes as investigações que incorporem olhares complementares à problemática da gentrificação, desde perspectivas diversas como o urbanismo crítico, configuração espacial e antropologia urbana. É sobre esse ponto que surgem as inquietações da dissertação, que busca complementar a teoria da gentrificação com outras aproximações ao fenômeno urbano.

O termo gentrificação foi usado pela primeira vez por Ruth Glass, em 1964, para descrever o processo social que acompanhava a requalificação de zonas habitacionais obreiras abandonadas ou subutilizadas em bairros londrinos e sua posterior transformação em bairros de classe média. A citação seguinte corresponde à clássica definição da socióloga.

Um por um, grande parte dos bairros da classe trabalhadora de Londres tem sido invadida pelas classes médias - altas e baixas. As degradadas e modestas ruas rodeadas por antigos estábulos, convertidos em moradias, e as casinhas - duas habitações para cima e duas embaixo - foram substituídas quando acabaram os contratos de aluguel por elegantes e custosas residências. Grandes casas da época vitoriana que estavam degradadas no período anterior ou mais recentemente - ao serem utilizadas como albergues ou ocupadas por varias famílias - tem aumentado novamente de categoria. Quando este processo de "gentrificação" começa em um bairro, avança rapidamente até que todos ou a maioria dos ocupantes iniciais, membros da classe trabalhadora, são deslocados, assim se modifica o caráter social do bairro. (GLASS, 1964, p. 18) 
Gentrificação (aburguesamento, elitização, enobrecimento ou nobilitação) diz respeito às distintas dimensões de uma transformação socioeconômica urbana que, além das mudanças físicas produzidas, pode gerar mudanças na estrutura social, no emprego, assim como mudanças na prestação de serviços nas áreas afetadas. Para Clark (2005), a gentrificação é uma mudança de usuários de um solo, em que uma classe socioeconômica superior substitui os usuários anteriores. Isto ocorre juntamente com transformações no ambiente construído.

Para os autores Lees et al. (LEES; SLATER; WYLY, 2008) a gentrificação está profundamente arraigada na dinâmica social e nas tendências econômicas. As características, os efeitos e as trajetórias são determinados por diversos motivos, como o contexto local, a configuração física, as características sociais dos bairros, as posições e os objetivos dos atores locais, as funções de dominação da cidade, a natureza da reestruturação econômica e a política do governo local, entre outras. Assim, a gentrificação se converteu em um tema importante, composto por uma variedade de fenômenos interessantes de ser examinados em uma cidade e principalmente no contexto de bairros.

Segundo explica Bidou-Zachariasen (2006), para vários autores o fenômeno da gentrificação é considerado como um processo natural e inevitável em cidades capitalistas. Outros autores, como Smith (2012), demonstram que o fenômeno não teria nada de natural e ocorreria principalmente pela influência do mercado imobiliário e do comportamento dos atores privados. Para Smith (2006), a gentrificação é um elemento fundamental na revitalização urbana, representando uma estratégia global nos diferentes centros urbanos. Isto se deve à aceitação do desenvolvimento imobiliário como o eixo central da expansão econômica da cidade, provocado pela vitória das políticas neoliberais. Dentro do discurso da revitalização urbana utilizado pelos negócios imobiliários encontram-se diversas motivações, como a requalificação de áreas degradadas, o repovoamento dessas áreas, e projetos que aproveitam terrenos públicos para investimentos privados.

Atualmente a gentrificação se desenvolve como uma forma de produção do espaço. Ela deixou de ser uma particularidade do mercado imobiliário para incorporar uma ampla renovação, econômica, social e política do espaço urbano nos lugares que intervém. Essa renovação está associada às transformações da paisagem física, da 
estrutura do emprego e do consumo, bem como das transformações nos modos de vidas, perspectivas que abordamos neste trabalho.

O principal item de conhecimento com que a teoria da gentrificação trabalha são os processos de transformação urbana em áreas centrais e pericentrais das cidades, e como essas transformações se relacionam com outros processos econômicos e políticos, tanto globais como locais. Uma das consequências do aburguesamento dos bairros é o deslocamento social da população mais pobre. Smith (2012) comenta que o termo gentrificação tem evoluído, passando de descrever aspectos de mudanças residenciais, para o estudo dos reinvestimentos de capital nos centros urbanos como mecanismo de produção de um espaço de classe. A gentrificação seria responsável, além dos novos projetos imobiliários, pela reconfiguração da cultura e dos padrões de consumo no espaço.

A literatura revisada sobre gentrificação organiza as formulações teóricas em duas tendências principais. Primeiro, pela oferta dos produtores privados do espaço, que tentam criar, nos centros, atrativos para as altas rendas e, em conjunto com estratégias do poder público, para dotar os centros urbanos de características competitivas em um mercado global. Essa tendência explica o processo como parte de um quadro estrutural, com grande importância dos aspectos econômicos da produção imobiliária e da renda diferencial do rent gap; destacam-se, neste grupo, os trabalhos de Neil Smith (1979, 1982, 1987, 2006, 2012). Segundo, pela demanda de classes médias por reconquistar territórios e voltar aos centros das cidades, depois de haver habitado conjuntos e loteamentos fechados nas periferias, principalmente em ondas estimuladas pelo setor imobiliário. O fenômeno é visto como uma estratégia de atores individuais que respondem a uma fascinação por modos de vida e de consumo dos centros das cidades (LEY, 1987; RODRIGUES, 1992; DÍAZ, 2004); destacam-se, neste grupo, os trabalho do geógrafo canadense David Ley. Nas pesquisas recentes a gentrificação é considerada mais globalmente, dentro do quadro do desenvolvimento do regime de acumulação de capital com os modelos de consumo das novas classes médias (HARVEY, 1991; SMITH, 1995, 2012b; LEES; SLATER; WYLY, 2008; LESS, 2008; SWYNGEDOUW, 2009; SLATER, 2011).

A primeira definição, denominada como enfoque da oferta, entende a gentrificação como produto da acumulação da renda urbana por um pequeno grupo de investidores em contexto de economias neoliberais. De acordo com a teoria do rent gap 
de Neil Smith, o elemento chave é a diferença entre uma venda futura ou potencial e a renda atual ou capitalizada existente nos imóveis das áreas gentrificadas. A valorização do solo geraria um grande potencial de lucro para os desenvolvedores imobiliários, os mesmos que gerariam a oferta. Assim, a expansão da renda diferencial define onde e quando se apresentam as melhores condições para a acumulação da renda urbana, que será apropriada por desenvolvedores e proprietários rentistas por meio de ações que desvalorizam os valores atuais para gerar a maior diferença potencial.

A segunda definição, com o enfoque na demanda, propõe que as principais causas da gentrificação estão nas mudanças culturais e na estrutura de ocupação da população. Ao contrário da visão da oferta, esta teoria, com base na demanda, dá maior importância às transformações nas orientações do consumo, trabalho e residência que acontecem nas classes acomodadas, as quais procuram se afastar de seus estilos de vida suburbanos. A tese desse enfoque é que existiria uma ideologia liberal da revitalização urbana, sustentada mais na qualidade de vida do que no crescimento econômico.

Perspectivas contemporâneas abandonaram a disputa sobre as causas do processo para se concentrar no estudo dos efeitos socioespaciais produzidos pelo fenômeno. Os estudos de casos no mundo anglo-saxão reconhecem recentes transformações na escala da gentrificação e propõem três fases do processo: 1) Nos anos 1960, uma etapa de produção espontânea ou "gentrificação esporádica" (LAURIANO, 2013), na escala de bairro, desenvolvida por pioneiros (artistas, empreendedores ou profissionais liberais) em busca de um modo de vida diferente atraídos pela centralidade (infraestrutura) e baixos preços, na maioria dos casos, promovida por políticas públicas orientadas a superar o deterioro urbano gerando as condições para o investimento imobiliário. 2) Nos anos 1980 até metade dos 1990, etapa de estratégias maiores de desenvolvimento econômico ou de consolidação da gentrificação, a gentrificação passa a formar parte do movimento de capitais financeiros globais através de parcerias entre o poder público e promotores imobiliários.

Os gentrificadores são as classes emergentes com capacidade de endividamento, executivos de empresas privadas ou yuppies. 3) No final dos anos 1990, chamada de gentrificação generalizada (SMITH, 2006), aparecem instrumentos econômicos mais flexíveis para a acumulação de capital (HARVEY, 2005), começando um aumento na escala e na internacionalização do capital financeiro com a ativa participação de 
governos centrais e locais, impulsionada por mudanças na legislação urbana para aumentar a renda dos investidores e produzir uma segunda onda de investimentos.

As pesquisas recentes mencionam que os países do Norte estão experimentando uma quarta fase da gentrificação, onde o processo implica a massificação sobre novos territórios, geografia e formas, incorporando frentes de água, pericentro, periferias urbanas e área rurais, revitalização e destruição criativa, vivenda, turismo, centros de negócios, residências de luxo, polos gastronômicos etc. (LEES; SLATER; WYLY, 2008).

Na atualidade, a gentrificação é um amplo campo de reflexão para as ciências humanas, particularmente a arquitetura e o urbanismo. Lees, Slater e Wyly (2008) mencionam cinco razões: 1) é um fenômeno urbano relativamente novo, de interesse para investigadores das cidades, aspecto importante nas reestruturações dos espaços metropolitanos; 2) é um desafio para as teorias clássicas sobre localização residencial e estrutura social; 3) é um tema político que analisa as consequências das políticas públicas de revitalização urbana na expulsão da população mais pobre; 4) constitui um desafio teórico e ideológico para a análise das reestruturações metropolitanas contemporâneas e sua relação com o direito à cidade; e 5) é um fenômeno mundial em desenvolvimento e se relaciona com o processo de globalização da economia, representando uma das chaves teóricas na geografia urbana.

A gentrificação na cidade contemporânea é uma estratégia urbana global entendida dentro da globalização neoliberal, onde os governos atuam mais como um agente pró-empresarial (LÓPEZ; GASIC; MEZA, 2012), e promovem a acumulação de capital como ente regular do mercado e protetor dos residentes desfavorecidos (LEES; SLATER; WYLY, 2008).

Os principais axiomas da gentrificação explicam como esses processos se relacionam com mercados imobiliários, constituindo um retorno aos centros urbanos, mas um retorno de capitais e não necessariamente de pessoas (SMITH, 2012b). As investigações de López (2015) na América Latina reconhecem três aspectos diferenciados nas causas da gentrificação. Primeiro, políticas públicas de macrotransformação da cidade para o reposicionamento da economia metropolitana no mercado global de serviços (city marketing). Segundo, investimentos públicos em acessibilidade e mobilidade, através de transformações de macro escala, e geração artificial de "capital espacial" internalizado por classes altas. Terceiro, microeconomias 
no mercado do solo, onde os agentes privados de maior status reestruturam e capitalizam as rendas assegurando uma certa continuidade para a localização de moradias populares, propiciando ou acelerando o processo de expulsão.

Janoschka, Sequera e Salinas (2013) estudam os discursos contemporâneos das políticas de gentrificação implementadas nas cidades latino-americanas e descrevem quatro dimensões características. A primeira dimensão é a "gentrificação simbólica", que explica como atuam os aspectos simbólicos nas estratégias de deslocamento. Segundo, dimensão dos novos mercados imobiliários, como a articulação entre gentrificação, abandono e deslocamento e atravessada pela criação de novos mercados imobiliários. A terceira dimensão é o papel do Estado no desenvolvimento de políticas neoliberais como elemento chave dos processos de gentrificação. Finalmente, a quarta dimensão a considerar seria a resistência à gentrificação.

$\mathrm{Na}$ gentrificação das cidades latino-americanas é fundamental a ação dos governos locais e nacionais. Não é suficiente a vontade de algumas classes socioeconomicamente altas. A elitização dessas cidades é também resultado de complexas políticas de estados pró-empresariais que restabelecem o máximo valor econômico do solo urbano para a captura dos agentes de mercado. Do ponto de vista do discurso oficial, a gentrificação é vista como um ativador das economias metropolitanas que beneficiaria um grande número de novos usuários, incorporando novos sistemas de transporte e infraestrutura nos bairros, mas os efeitos acabam segregando segundo a capacidade econômica ou cultural para aceder aos meios da mobilidade. O resultado da gentrificação na América Latina são os mercados fundiários e habitacionais que aumentam o acesso aos espaços reestruturados para as classes altas, enquanto restringem a oferta de moradia para segmentos de menor renda, que acabam deslocados, expulsos ou excluídos do lugar.

A gentrificação é uma teoria política, que incorpora deslocamento das classes baixas e a ação das políticas públicas. As tentativas de explicar o fenômeno sob a perspectiva do consumo foram superadas, e atualmente a gentrificação deve ser entendida com um fenômeno amplo de oferta e demanda, de produção e consumo espacial, econômico e cultural. As perspectivas e metodologias estão vinculadas às diferentes escalas de aproximação, com ênfases na escala micro e individual, enquanto outros analisam a dimensão urbana e econômica como fenômeno local e global. Uma orientação crítica destaca a resistência à gentrificação por parte dos movimentos sociais 
urbanos, como contestação a quem argumenta possíveis benefícios das políticas de "requalificação" dos centros pelas classes médias.

\section{Teoria da Sintaxe Espacial}

Entre as várias teorias sobre o espaço urbano, a Teoria da Sintaxe Espacial (TSE) (HANSON; HILLIER, 1984) apresenta um valioso instrumento de análise pelas relações que estabelece entre aspectos sociais e espaciais da configuração urbana. Nesta pesquisa, a TSE é utilizada como arcabouço teórico, campo metodológico e ferramenta de análise, pois estabelece um método de estudo dos padrões espaciais.

Os conceitos da TSE foram originalmente formulados nos anos 1970 por pesquisadores da Bartlett Faculty of Built Environment da University College of London, mas foi em 1984, com o livro The Social Logic of Space, de Bill Hillier e Julienne Hanson, que foram desenvolvidos o corpo teórico e os procedimentos metodológicos e instrumentais. As bases da teoria provêm de um pensamento sistêmico e estruturalista, que deriva da preocupação dos autores com as anteriores teorias normativas e pouco analíticas em arquitetura.

Os autores criticam aqueles que preferem discutir a arquitetura em termos de estilos visuais; convidam a sair do nível das aparências e imergir no nível do espaço (HANSON; HILLIER, 1984). A teoria propõe que certos aspectos das relações sociais no espaço e sua apropriação são condicionados por arranjos morfológicos, ou seja, pela forma como se dispõem e se relacionam os elementos arquitetônicos que abrigam as atividades humanas (BRANDÃO, 2003).

\footnotetext{
A ordem espacial é um dos meios mais marcantes pelo qual reconhecemos a existência das diferenças culturais entre uma formação social e outra, ou seja, as diferenças nas formas em que membros dessas sociedades vivem e reproduzem sua existência social. (HANSON; HILLIER, 1984, p. 27)
}

Existiria, assim, uma relação entre a configuração e o funcionamento do espaço. A análise sintática se baseia na relação entre os atributos físicos do espaço urbano e os potenciais padrões sociais, considerando representações, quantificações e medições dessas potencialidades (MEDEIROS, 2006). 
Uma abordagem sintática incorpora técnicas de representação do espaço, fornecendo informações ao pesquisador para avaliar as articulações urbanas, e descrevendo as potenciais interações e os contatos de fluxos de diferentes agentes. As categorias analíticas da sintaxe são relacionadas às barreiras e às permeabilidades ao movimento e também às transparências e opacidades à visão. Elas são ferramentas de compreensão da dimensão sintática da cidade, que é constituída pelo modo de agrupação ou arranjo espacial. Esse arranjo espacial é o modo como os espaços da cidade se estruturam e articulam entre si, construindo a forma espacial urbana (AGUIAR, 2012).

A TSE, mediante um método e técnicas, estabelece relações entre as categorias ou atributos de dois âmbitos: o espaço (público ou privado) organizado para fins humanos e a estrutura social, ou seja, os modos de interação de indivíduos e grupos, camadas sociais e suas estruturas de poder (HOLANDA, 2001; MEDEIROS, 2006).

O principal item de conhecimento da TSE são as relações entre o espaço e a sociedade (HOLANDA, 2002). Em outras palavras, a TSE entende a configuração como um complexo de relações de interdependência entre a forma-espaço (cidade física) e a sociedade (cidade humana). Essa teoria evidencia as relações entre a estrutura espacial da cidade e seus edifícios, a dimensão espacial de estruturas sociais, e as variáveis sociais, como uma tentativa de revelar a lógica do espaço arquitetônico e a lógica das sociedades (HOLANDA, 2002).

Hillier (1989) afirma que para compreender a cidade e a arquitetura dentro de sua complexidade sociocultural, é necessário entender as leis implícitas que relacionam o objeto construído com a sociedade. Essas leis, para o autor, são três: 1) as leis do objeto propriamente dito, modelos em que as construções se desdobram no espaço volumétrico; 2) as leis da sociedade para a forma urbana; como a sociedade usa e modifica as leis do objeto, dando forma aos tipos e padrões de relações sociais; 3) as leis da forma urbana para a sociedade; como a forma urbana afeta a sociedade. Holanda (2002, 2010, 2013) sugere uma quarta lei, 4) as leis da sociedade propriamente dita, ou da sociedade em si, as próprias relações sociais como sistemas de arranjos espaciais (MEDEIROS, 2006).

Dessas leis descritas deriva a configuração do espaço produzido pela sociedade que o habita. Portanto, a TSE estuda a relação entre a configuração, entendida como a forma-espaço ou estrutura espacial da cidade, e como a sociedade utiliza e se 
movimenta dentro dessa configuração. Para a TSE, pela análise do espaço podemos descobrir algumas lógicas da sociedade. Como os arranjos espaciais estão impregnados da cultura da sociedade, cada organização espacial produz desempenhos diferentes. Para reconhecer esses desempenhos, as ferramentas de análise permitem simular a realidade procurando similaridades e diferenças, padrões e hierarquias.

O campo de reflexão da sintaxe espacial são as relações arquitetura $x$ comportamentos. A teoria estuda os potenciais movimentos de pessoas e a vida espacial, entendida como um sistema de encontros e esquivanças, para determinar padrões de encontros sociais no espaço. A TSE se posiciona como uma "ponte" (MEDEIROS, 2006) entre a vida social, compreendida como um conjunto de atributos socioeconômicos que se relacionam com os padrões espaciais; e a vida espacial, entendida como um sistema de encontros e esquivanças (HOLANDA, 2002), para assim, revelar a lógica desta última.

Para Hillier e Hanson (1984) o espaço é construído em função das formas de solidariedade social, as quais, ao mesmo tempo, são produto da estrutura da sociedade. Para os autores as diferentes formas espaciais seriam reflexos de cada sociedade, pois assim como a sociedade teria uma lógica espacial, o espaço também teria certa lógica social. Desta forma, na medida em que uma sociedade é um fenômeno global e local, ou espaço também responde a uma estrutura global (HANSON; HILLIER, 1984).

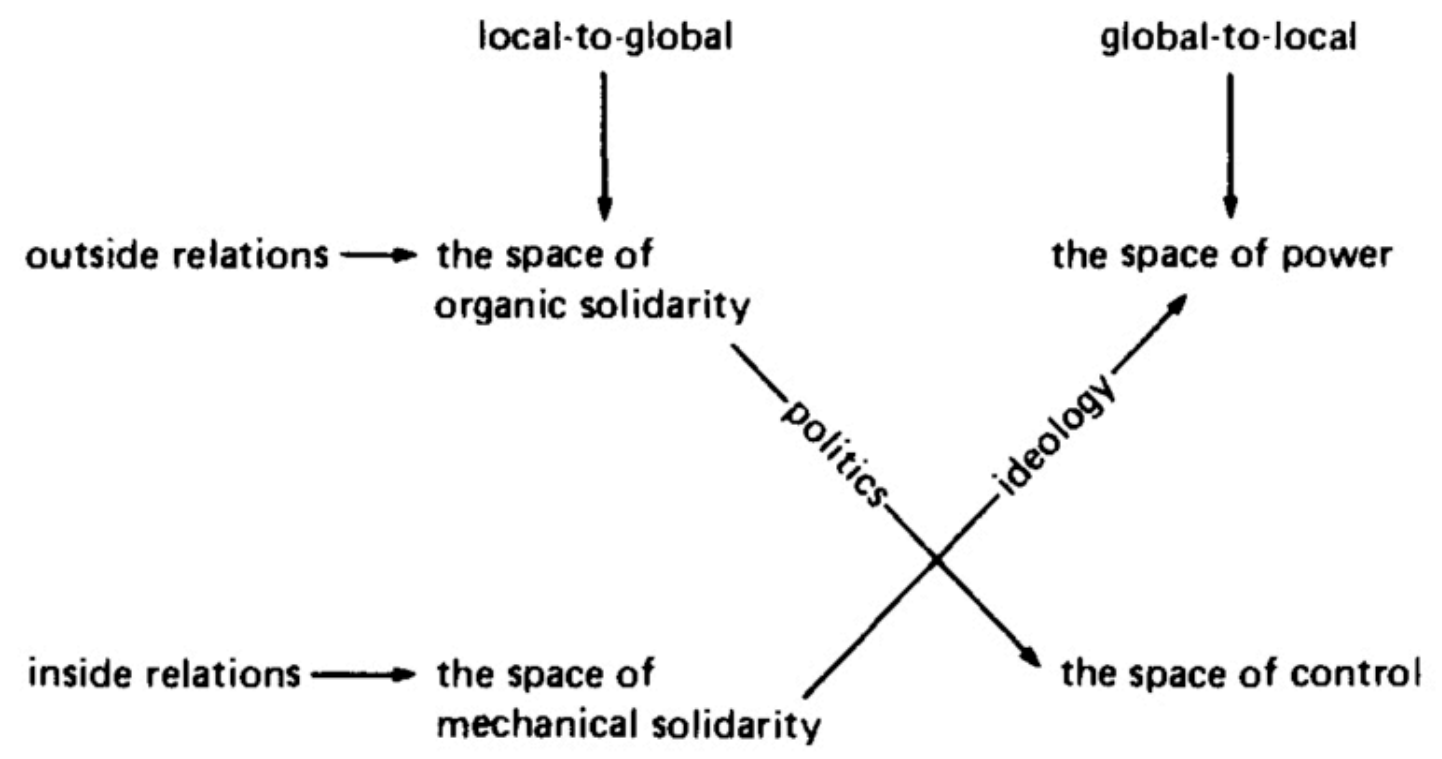

Figura 3: Esquema da relação entre dinâmicas sociais e espaciais nos níveis globais e locais.

Fonte: (HANSON; HILLIER, 1984, p. 22). 
Na figura 3, os autores apresentam um diagrama que resume como as dinâmicas sociais são articuladas pelo potencial social do espaço; e mostram a influência das políticas no controle do espaço e das ideologias na formação dos espaços de poder numa escala local e global.

Segundo Holanda (2013), "o axioma central da Teoria da Sintaxe Espacial é: o espaço socialmente organizado pelos humanos é função de formas de solidariedade social" (HOLANDA, 2013, p. 264). Para Holanda (2013) o axioma deriva de duas ideias: 1) o mundo material, de objetos, e o mundo imaterial, de sujeitos, não são separáveis, eles se produzem um ao outro, por isso, 2) “o espaço produzido já nasce social” (HOLANDA, 2013, p. 265).

Medeiros (2006) destaca que a TSE relaciona dois tipos de atributos: 1) a formaespaço organizada por e para fins humanos, correspondendo às escalas da cidade e seus edifícios; e 2) a estrutura social, modos de relações entre sujeitos, grupos, classes e estruturas de poder (MEDEIROS, 2006).

Para Hillier (2007) os principais atributos que favorecem ou restringem os encontros entre pessoas em determinados espaços não são as características dos indivíduos, mas sim os padrões e as configurações do espaço e dos grupos de pessoas. O autor expressa que no desenho de edifícios ou espaços abertos não é possível configurar as pessoas, por tanto, de existir relações entre essas pessoas e o espaço, estas se encontrariam no nível da configuração espacial. Assim, a relação entre o espaço e a existência social não estaria presente nas atividades individuais e sim, nas relações entre as configurações de pessoas e as configurações do espaço. 


\section{Teoria da Ecologia Humana}

As transformações que afetavam a população das grandes cidades no início do século XX motivaram os sociólogos da Escola de Chicago, que realizaram inumeráveis investigações e se converteram na principal herança da antropologia urbana. Robert E. Park e Louis Wirth representam dois dos principais expoentes da teoria oriunda daquela universidade: a Ecologia Humana, que estuda a estrutura sociológica da cidade.

O passo da sociedade rural para a urbana provocou intensas mudanças sob todos os aspectos da vida social, o que levou os pesquisadores a considerar as grandes cidades como o laboratório do comportamento coletivo. A Cidade de Chicago, em especial, teve uma posição estratégica dentro dos Estados Unidos. Próxima de Mississipi, ela concentrou muitos migrantes negros. Os problemas do racismo e da segregação racial foram o tema principal das pesquisas iniciais. Justamente, um dos primeiros livros sobre o chamado "problema negro" nas cidades industriais foi Philadelphia Negro: a Social Study, de W. E. B. Dubois, publicado em 1899. Dubois foi um dos fundadores do panamericanismo negro; ele foi criado por uma família branca e foi o primeiro aluno negro em Harvard. O livro é uma extensa pesquisa sobre o racismo na cidade. A figura 4 mostra um exemplo dos levantamentos realizados por dezenas de estudantes.

Chicago nessa época era descrita como uma cidade de contrastes. Depois de um incêndio em 1870, a zona central da cidade foi reconstruída, surgiram os primeiros arranha-céus e multiplicaram-se as áreas urbanas elitizadas. Mas a altura dos edifícios contrastava com a miséria da maioria dos imigrantes. Irlandeses, alemães, polacos, húngaros, chineses, entre outros, chegaram à cidade fugindo da fome na Europa e atraídos pelo desenvolvimento da indústria. Segundo a nacionalidade, os imigrantes se localizavam em áreas bem delimitadas da cidade e conservavam muitos de seus costumes.

Essa situação chamou a atenção de Robert E. Park e outros investigadores do Departamento de Sociologia da Escola de Chicago que decidiram estudar a cidade, seus bairros e seus habitantes. Park percebeu um fenômeno similar ao que acontece nas espécies vegetais e animais em relação ao território que habitam, comparando-o como uma verdadeira ecologia humana. 

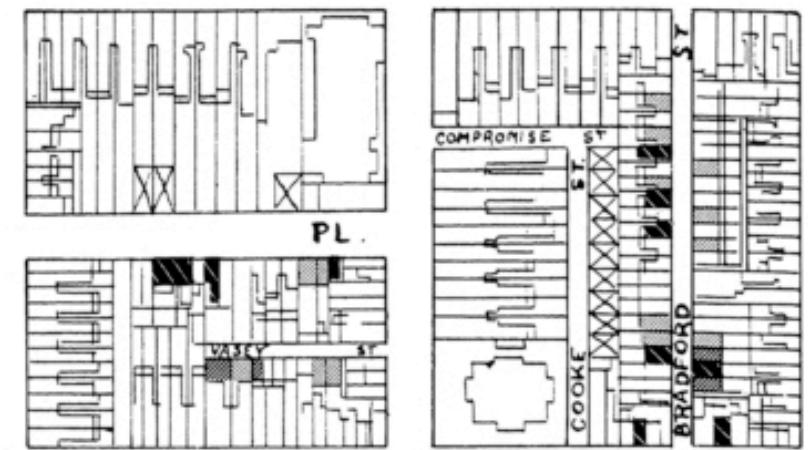

PINE
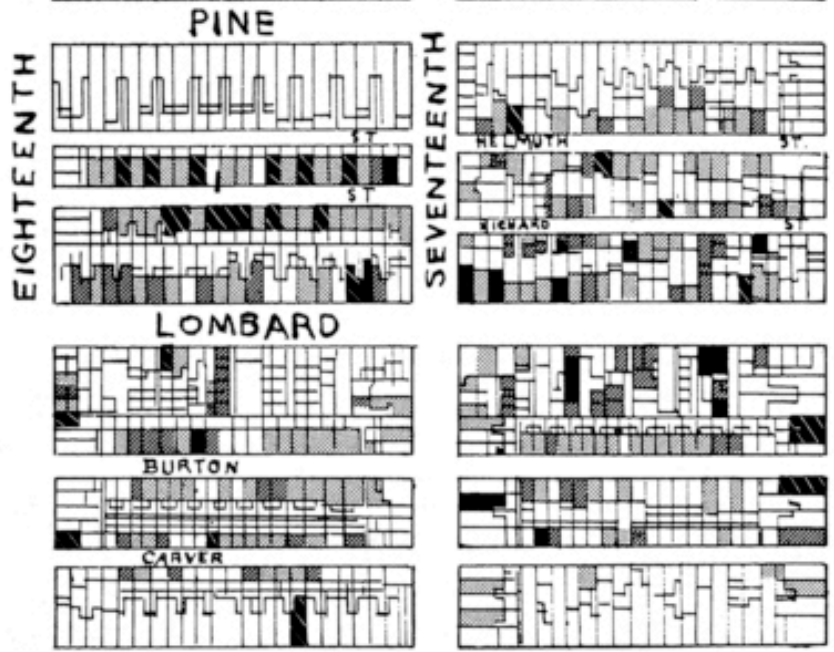

Grade 4: Vicious and Criminal Classes.

Wrade 3: The Poor.

Grode 2: The Working People - Fair to Comfortable.
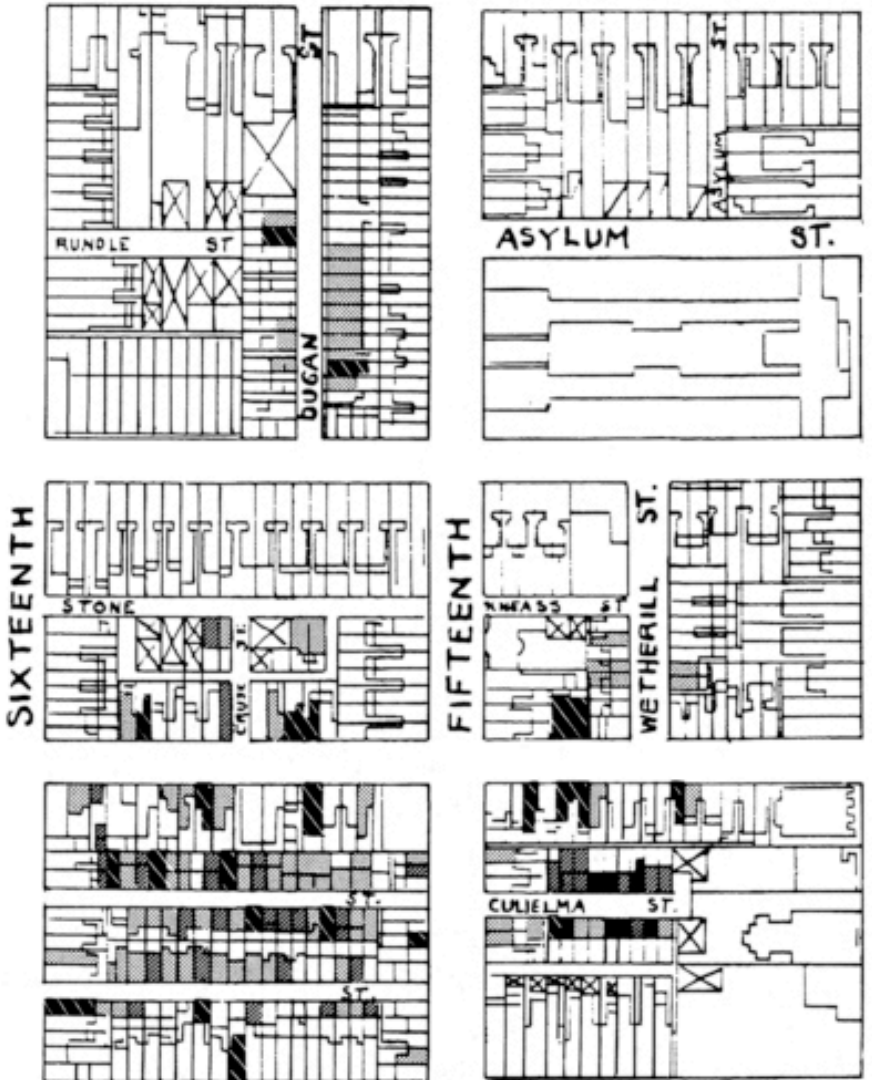

MIIV Grade 1: The "Middle Closses" and those above.

Residences of Whites, Stores, Public Buildings, etc.

Figura 4: Distribuição da população negra e sua condição social em um distrito de Philadelphia.

Fonte: (DUBOIS, 1899, p.65-65).

Robert Park, formado em filosofia, trabalhou como jornalista e teve contato com Booker T. Washington, escritor e educador norte-americano que tinha ideias diferentes das de Dubois em relação à solução para a exclusão dos afro-americanos. A experiência como jornalista e a influência de Georg Simmel fizeram Park desenvolver uma abordagem etnográfica a respeito da vida urbana.

Park, em seu texto A cidade: sugestões para a investigação do comportamento humano no meio urbano (1915), considera o urbanismo em uma grande escala, mas também observa os detalhes que ocorrem na cidade, principalmente nos bairros. Em uma escala maior, a cidade pode ser definida, primeiro, como uma organização material, com sua forma física, sua geometria, ou sob uma perspectiva espacial, como as relações entre os cheios e vazios; e, segundo, como uma organização moral, expressão da natureza humana e de uma cultura particular, possuidora de costumes e tradições. 
A cidade é sobretudo um estado de ânimo, um conjunto de costumes e tradições, de atitudes organizadas e de sentimentos inerentes a esses costumes, que se transmitem mediante dita tradição. Em outras palavras, a cidade, não é simplesmente um mecanismo físico e uma construção artificial: está implicada nos processos vitais das pessoas que a formam; é um produto da natureza e, em particular, da natureza humana. (PARK, 1999, p.49)

Em uma escala menor, dentro das cidades identificam-se partes diferentes, como as vizinhanças ou os bairros, que têm sentimentos particulares de seus habitantes. Essas áreas constituem unidades sociais que organizam a vida urbana de acordo com as relações de proximidade e contato espontâneo entre os vizinhos. Também dentro dessa escala menor existem guetos, que representam áreas de segregação ou isolamento de raças ou classes sociais onde se produzem relações de intimidade e solidariedade.

Park, depois de interpretar a cidade como um mosaico de mundos que se tocam, mas que não se interpenetram, e como um laboratório social, define a Ecologia Humana como a ciência que estuda a ordem e as características do agrupamento humano (PARK, 1999). Em outras palavras, a ciência que estuda a organização ecológica da cidade, que pode se servir do método antropológico para investigações urbanas.

Wirth, por sua parte, em O urbanismo como modo de vida (1938), formula uma definição científica de cidade. Ele se concentra em identificar as características do urbanismo como forma diferenciada de vida com foco nos habitantes (HANNERZ, 1986). Para o autor, as cidades amoldam o caráter da vida social a uma forma especificamente urbana, dominando e influenciando um espaço (hinterland) às vezes maior do que a própria área da cidade. As cidades se caracterizam por: 1) o tamanho da população, 2) a densidade, e 3) sua função. Com base nessas características o autor propõe uma definição sociológica da cidade "como um estabelecimento relativamente grande, denso e permanente de individuos socialmente heterogêneos" (WIRTH, 2005, p.4). Ele define três pontos de vista sobre o urbanismo: 1) a estrutura física da população, 2) como sistema de organização social e 3) como um conjunto de atividades e ideias.

Os autores concordam que a cidade moderna, entendida como lugar de comércio, mercado e negócios, gera relações espaciais e sociais de competitividade e a especialização das funções de seus habitantes e da própria cidade. Essas condições transformam a cidade num espaço em constante conflito, tensão social e crise, que afeta 
o modo de vida de seus habitantes ao mesmo tempo em que esse modo de vida afeta a cidade. Em outras palavras, assim como o homem constrói a cidade, a cidade constrói o homem e seu modo de vida (WIRTH, 2005).

Um dos textos mais importantes desenvolvidos na Escola de Chicago é: Black Metropolis. A study of Negro life in a Northern city (1945), de St. Clair Drake e Horace R. Cayton. O livro é resultado de uma pesquisa histórica e sociológica da vida urbana da população negra que chegou a Chicago para trabalhar nas indústrias. Black Metropolis foi o nome com que se conhecia o bairro de Bronzeville no inicio do século XX, por concentrar a grande parte da população afro-americana. Os autores descrevem duas formas básicas de crescimento espacial das cidades do centro-oeste norte-americano: primeiro, uma tendência dos brancos nativos de mudar regularmente desde o centro para áreas mais prósperas na periferia, abandonando o centro que começou a se deteriorar. Segundo, uma tendência dos imigrantes a se estabelecer em colônias próximas do centro e dos postos de trabalho; os assentamentos da população negra formaram um cinturão negro ou black belt (DRAKE; CAYTON, 1993). As últimas áreas foram identificadas pelos autores como guetos por causa da pobreza, da homogeneidade e das péssimas condições de moradia da população.

O principal item de conhecimento da Ecologia Humana é a cidade, entendida como produto da natureza humana e como laboratório social. Outro item de conhecimento e foco da maioria das investigações são os bairros da cidade. Wirth (2005) argumenta que, não sendo possível conhecer a cidade com um todo, o estudo de seus bairros ajudaria a entender as características da vida urbana. Em Park (1999) existia uma preocupação pela ordem moral da cidade, relacionando a localização com certos valores dos indivíduos em seu comportamento. Essa diferenciação é estabelecida por processos de segregação, que convertem a cidade em um mosaico de mundos diferentes.

A Ecologia Humana era pensada como uma sociologia do espaço que reconhecia a competição com o principal mecanismo de regulação na luta pela existência na cidade. Partindo dessa ideia, Park e Burgess elaboram um modelo espacial para a cidade de Chicago (figura 5a), dividindo a cidade em círculos concêntricos, identificando zonas da cidade segundo as funções e seus ocupantes. O modelo mostra como a especialização comercial e a segregação residencial gira em torno do centro da cidade, mas com uma particularidade. As regiões mais pobres cercavam o centro comercial, enquanto as zonas 
mais privilegiadas estavam na periferia exterior. A figura $5 \mathrm{~b}$ apresenta o modelo desenvolvido por Drake e Cayton como uma adaptação do modelo de Park e Burgess. A representação é menos abstrata que o modelo anterior, indicando o localização do lago e as zonas de crescimento.

Uma das principais formulações teóricas do urbanismo como modo de vida é reconhecer três pontos de vista para observar a cidade, como: 1) estrutura física (ordem ecológica); 2) sistema de organização social (estrutura, instituições e relações sociais); 3) conjunto de atitudes e ideias (diferentes pessoalidades que resultam em uma conduta coletiva sujeita a mecanismos de controle social).
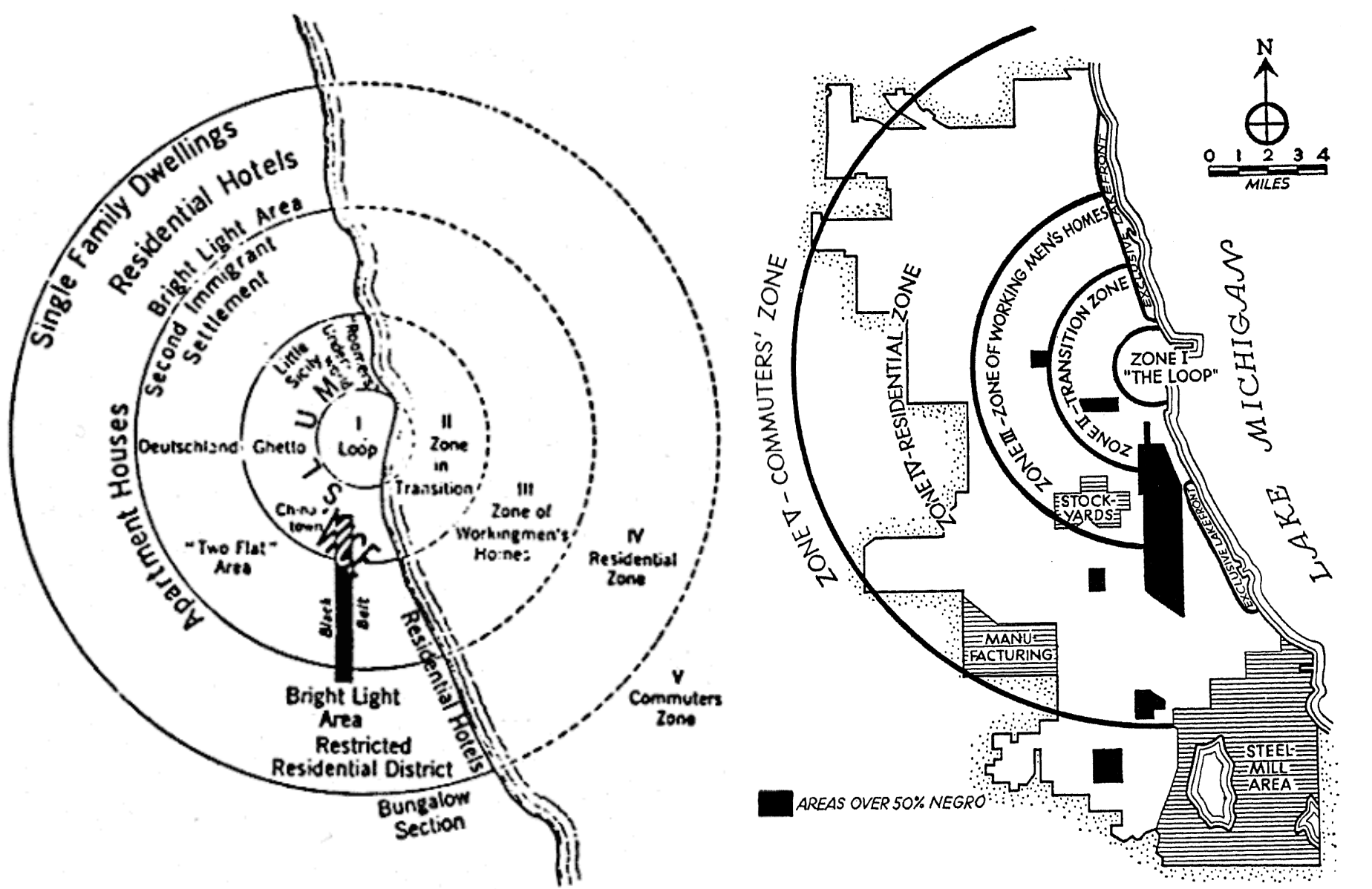

Figura 5a: Modelo original de Park e Burgess.

Fonte:[http://web.uchile.cl/vignette/revistaurbanismo/n3/leidenberger/leidenberger.html].

Figura 5b: Modelo de Drake e Cayton. Fonte: (DRAKE; CAYTON, 1993, p. 16).

O campo de reflexão da Ecologia Humana é a relação entre meio urbano e comportamento humano. Para seu estudo, propõe-se uma ciência multidisciplinar com uma concepção "espacializada" do social e socializada do espaço. A Ecologia Humana define seu principal axioma como: as grandes cidades representam laboratórios do comportamento coletivo e estão em constante tensão, devido aos conflitos pelo espaço. 
Esses conflitos criam fronteiras, demarcadas dentro da cidade, que delimitam áreas naturais dos grupos e seus padrões.

O enfoque inicial da Escola de Chicago foi a noção de cultura urbana, em formação na cidade, colocando em prática as pesquisas etnográficas para analisar temas como: marginalidade, segregação, criminalidade, prostituição, etc. Os trabalhos desenvolvidos sobre cultura urbana estabeleceram um novo campo de reflexão e pesquisa, influenciando a antropologia urbana no Brasil, principalmente em São Paulo nos anos 1940 e 1950, e no Rio de Janeiro, nos anos 1970 e 1980.

Gilberto Velho foi pioneiro e desenvolvedor da antropologia urbana como disciplina no Brasil. Como resultado de suas primeiras investigações, publica $O$ Barata Ribeiro 200 (1970), A Utopia Urbana (1973) e Desvio e Divergência (1974), trabalhos que introduzem uma nova temática - o estudo dos setores médios - nas investigações sobre o meio urbano sob uma perspectiva antropológica. Seus trabalhos incorporam metodologias flexíveis e novos enfoques ao estudo da sociedade urbana, ressaltando a importância do trabalho de campo, da observação participante e das entrevistas, com o objetivo de identificar os códigos que se escondem atrás das aparências dos investigados.

Em O Barata Ribeiro 200, o autor realiza uma etnografia do cotidiano dos habitantes do Edifício Richard em Copacabana. O edifício, localizado em uma das zonas de maior movimento do bairro, foi inaugurado em 1957 e era habitado por uma população heterogênea de classe média e média baixa de aproximadamente duas mil pessoas que moravam em pequenos apartamentos de $25 \mathrm{~m}^{2}$ a $40 \mathrm{~m}^{2}$. Apesar do status e prestígio que a localização dava a seus residentes - na Zona Sul de Rio de Janeiro - o edifício sofria de forte estigma por parte de outros moradores do bairro. Velho se pergunta pela ideologia de seus ocupantes que os leva a deixar suas residências de origem, muitas vezes com melhores condições de habitabilidade, para cumprir o desejo de aceder a bens de consumo que o bairro oferece, ainda que em condições precárias (VELHO; MAGGIE, 2012).

A Utopia Urbana se pergunta por que os habitantes do "Edifício Estrela" foram viver em Copacabana. O bairro, que passou por um período de crescimento desordenado e que sofria problemas como: densificação, conflitos sociais, dificuldades de mobilidade e higiene, continuava atraindo pessoas a viver em apartamentos conjugados de $27 \mathrm{~m}^{2}$. 
Neste livro o autor trabalha com uma categoria social específica - os white-collar procurando entender, sob o ponto de vista deles, como o bairro representa um campo de possibilidades socioculturais . Igual ao Edifício Richard, o "Estrela" era considerado de "baixo padrão moral" e com sérios problemas de habitabilidade, o que provocava conflitos e tensões entre os vizinhos. A hipótese do livro propõe que a decisão de chegar ao bairro se deve a símbolos como o prestígio e o status, que expressam uma distribuição de poder dentro da sociedade. O prestígio está na problemática da mobilidade social através de categorias (que o autor chama de unidades mínimas ideológicas). Ele reconhece uma hierarquia entre os distintos bairros da cidade e as pessoas se definem segundo o lugar onde vivem, ou seja, existiria uma correlação entre o prestígio social e o lugar de residência.

No artigo Estigma e comportamento desviante em Copacabana (do livro Desvio e divergência), Gilberto Velho tem como objetivo relacionar situações de estigmatizacão encontradas em suas investigações anteriores, com acusações de comportamento desviante no bairro. Nos chamados edifícios "balança" o estigma gera uma desvalorização dos apartamentos que se manifesta de duas maneiras: primeiro, devido a uma crença dos vizinhos de que seus habitantes são de uma posição social inferior, e segundo, porque se identifica o lugar como pouco recomendável para famílias. Neste texto, o autor indaga sobre a ambiguidade provocada na identidade dos habitantes, quem, por um lado, tem o status do bairro e, por outro, sofrem pelo estigma do edifício, o que o autor chama de "discrepância de identidades". Os problemas registrados nos edifícios eram principalmente de convivência, atribuídos a supostos indivíduos desviados, como prostitutas e homossexuais, categoria que é outorgada pela relação social com o não desviado.

Gilberto Velho responde com investigações empíricas à sua pergunta sobre como a antropologia social pode ser útil para a investigação do meio urbano. Em seus estudos dos estratos médios urbanos se reconhecem aspectos da vida nas grandes cidades como: a heterogeneidade, o individualismo, o anonimato, o desvio e a estratificação social, entre outros, conceitos com os quais ampliou o campo de conhecimento, para a antropologia urbana e para outras disciplinas das ciências sociais que se interessam pela cidade. 


\section{Método de reconstrução do processo histórico}

A dissertação foi desenvolvida em cinco etapas: 1) Planejamento, onde se define o problema e o caso de estudo, se formulam as perguntas, se desenvolve a discussão teórica e se determinam a hipótese e as variáveis. 2) Trabalho de campo: considera a definição das técnicas de coleta de informação e as técnicas de análise, além da seleção da amostra a considerar e, posteriormente, se realiza o levantamento de dados. 3) Análise de dados, sistematização das informações e discussão dos resultados do levantamos in loco. 4) Operações intelectuais, interpretações dos resultados e revisão dos conceitos teóricos. 5) Relatório de pesquisa, conclusões e apresentação do informe final.

Nas pesquisas sobre gentrificação não existe uma metodologia definida, os caminhos de investigação são diversos e respondem a cada caso. Independentemente da vertente teórica, seja cultural ou econômica, numerosos casos de estudo se concentraram em medir o processo de gentrificação dos bairros. Um debate emergente pergunta pelo papel dos atores estatais nos avanços da elitização nas cidades, argumentando que a intervenção do poder público é fundamental para a aparição do fenômeno.

Para pesquisar o processo de gentrificação e seus múltiplos aspectos utiliza-se como metodologia o estudo de caso com desenho misto, considerado adequado para investigações que relacionam o fenômeno estudado e o contexto social em que acontece. O desenho misto é uma complementação de técnicas quantitativas e qualitativas no levantamento de dados que controlem um número reduzido de variáveis (enquetes, questionários, entrevistas, observação direta etc.), também chamado de amostra intensiva. Essa metodologia permite uma interpretação exaustiva das situações, decisões e comportamentos nos processo sociais (GASIC, 2013).

Nesta pesquisa, que considera a Vila Planalto como caso de gentrificação, o fator mais importante é investigar a aplicação do marco teórico no processo local. A vantagem do estudo de caso é o aporte para a construção de conceitos teóricos a partir de uma situação social concreta e multifatorial. Para o desenvolvimento da análise é necessária a reconstrução histórica a partir dos fatos do bairro, para posteriormente reinterpretar os conceitos utilizados pelas teorias e sua potencial aplicação no caso de estudo. A continuação explicamos alguns dos mais importantes conceitos definidos pela teoria da gentrificação e que são referências para a investigação. 
1. Direito à cidade: O "direito à cidade" é um direito à vida urbana, a construir um ritmo de vida cotidiana, definido pelos desejos das pessoas; é o direito a definir o ritmo de vida na cidade. O conceito foi incorporado em 1968 por Henri Lefebvre, propondo uma visão política e prática diante dos efeitos provocados pela mercantilização do espaço urbano na qualidade vida das cidades modernas. O direito à cidade baseia-se na ideia da cidade como obra (valor de uso), como produto cultural e coletivo, construção da sociedade em determinado momento histórico (LEFEBVRE, 1969). A cidade como espaço público e político deveria ser um lugar onde as necessidades e os desejos de seus habitantes sejam respondidos, concebida como um espaço para a solidariedade, mas, devido às forças que operam nela, encontra-se em constante conflito social e de classe.

Lefebvre (1969) descreve como o capital industrial tomou o controle das cidades e dos núcleos urbanos, dominando a dimensão econômica e a vida social. O processo de industrialização e posterior neoliberalização do modo de produção promoveu a exclusão da população de baixa renda apartada nas periferias, em centros deteriorados, guetos ou deslocada de seus bairros por processos como o enobrecimento.

David Harvey (2012) reinterpreta as ideias desenvolvidas por Lefebvre, ampliando o conceito do direito à cidade, não como o simples direito ao acesso, mas, também como o direito a imaginar, reconstruir e transformar a cidade e a vida urbana em algo diferente ao existente. Assim, a cidade deve responder aos desejos de quem a habita e (re) produz (HARVEY, 2012). Para o autor, a urbanização cumpre um papel fundamental no modelo capitalista, absorvendo o excedente necessário para a geração de plusvalía. Por isso, diversos projetos de reconfiguração urbana nas cidades globais transformam a forma física (infraestrutura) e também as formas de vida e o tipo de habitante (sociedade), fortalecendo o papel das cidades como centros de consumo, turismo e lazer.

Harvey (2012) admite que a reconfiguração da geografia urbana se produz também a escala planetária, expressada na ampliação da urbanização como necessidade de expansão do capital. Esse tipo de intervenção transforma a qualidade de vida urbana em mercadoria (valor de troca) disponível apenas para quem pode pagar. Desta forma, a requalificação, além de gerar deslocamento e perda da renda do solo, cria fissuras (HARVEY, 2012). 
O direito à cidade, em geral, é visto sob uma perspectiva filosófica ou política, poucas vezes se dá atenção à natureza legal e suas implicações. Neste sentido, o caso do Brasil merece especial atenção porque regulamentou o direito à cidade com a criação do Estatuto da Cidade.

Com a aprovação do Estatuto da Cidade em 2001 a legislação brasileira converteu-se em exemplo mundial no reconhecimento do direito e criou um marco regulador do desenvolvimento e da gestão urbana (FERNANDES, 2007). O Estatuto da Cidade é a lei federal $\mathrm{N}^{\mathrm{o}} 10.257$ de 2001, que regulamenta os artigos 182 e 183 da Constituição de 1988, sobre política urbana.

Depois de longo período de lutas de diversos movimentos sociais, com destaque do Movimento Nacional de Reforma Urbana, foi criado o Fórum pela Reforma Urbana que apresenta suas demandas à Assembleia Constituinte através de uma Emenda Constitucional de Iniciativa Popular. $O$ resultado foi a inclusão dos artigos na Constituição Federal que determinam que a responsabilidade de implementar a política urbana é dos municípios, bem como a de garantir as funções sociais da cidade e o bemestar dos habitantes. O Plano Diretor Municipal é o instrumento para definir o uso e a ocupação da terra urbana, devendo ser aprovado pelas Câmaras Municipais. Os artigos reconhecem a função social da propriedade urbana, função desempenhada quando se obedece a ordenação disposta no plano diretor, e se reconhece o direito de ocupar de maneira pacífica áreas urbanas privadas.

Passaram 13 anos para esses artigos serem regulamentados, quando em 2001 foi aprovado o Estatuto da Cidade. A lei, considerada outra conquista social, estabelece normas para que o uso do solo urbano assegure o bem coletivo e o equilíbrio ambiental. A lei tenta dar um enfoque holístico ao desenvolvimento urbano, centrado na gestão democrática das cidades (CARVALHO; ROSSBACH, 2010). Para Fernandes (2007), o estatuto se fundamenta em quatro dimensões 1) conceitual, com definições para interpretar a função social da propriedade urbana; 2) regulamentação dos novos instrumentos legais, urbanísticos e financeiros dos municípios; 3) processos de participação para a gestão democrática; e 4) identificação de instrumentos legais para a regularização de assentamentos informais.

O texto do estatuto, apesar de completo e bem desenvolvido, não resolve problemas estruturais de uma sociedade desigual nem consegue assegurar o direito à cidade ou à moradia legal. A concretização de políticas e programas reais por parte dos 
municípios é lenta, e passados quase 15 anos desde a aprovação do estatuto poucos municípios implementaram os planos diretores. A nível federal, em 2003, foi criado o Ministério das Cidades que, em 2004, implementa o Conselho Nacional das Cidades para discutir e decidir sobre as políticas habitacionais e urbanas.

2. Deslocamento: operação que restringe as alternativas dos setores mais vulneráveis da sociedade para conseguir um local adequado para viver. Ocorre quando grupos sociais com maior acesso ao capital econômico, social e cultural chegam a um bairro. O deslocamento acontece quando a vida no lugar é impossibilitada e transformada em algo economicamente inacessível, assim os residentes se veem na obrigação de abandonar sua moradia e o bairro (CASGRAIN; JANOSCHKA, 2013).

Marcuse (2000) descreve quatro dimensões do deslocamento: 1) o deslocamento do último residente, que considera só o número de moradias afetadas; 2) deslocamento em cadeia: inclui todos os lares que no processo de gentrificação/abandono podem ter sido sucessivamente deslocados; 3 ) deslocamento exclusivo, quando os residentes não podem mais aceder à moradia devido à elitização; e 4) a pressão por deslocamento, que ocorre quando os setores mais desfavorecidos da população são despejados para outros lugares durante a transformação de um bairro (MARCUSE; VAN KEMPEN, 2000; MARCUSE, 2009).

3. Reabilitação: As cidades estão em constante transformação e, dependendo da ação do Estado e do mercado sobre a produção do espaço, em determinadas áreas urbanas ocorre maior desenvolvimento de atividades econômicas em detrimento de outras áreas, que decaem. Como resposta a esse processo, os agentes públicos desenvolvem políticas urbanas de intervenção para as áreas consideradas por eles como "degradadas" ou "abandonadas" seguindo duas tendências: a primeira, de reabilitação, com projetos de melhorias das condições existentes; e a segunda, de revitalização, erradicando e renovando o ambiente construído.

Essas intervenções se desenvolvem desde tempos remotos, porém, é desde os anos 1970 que estudos urbanísticos trabalham o conceito de reabilitação do ambiente construído. Em cidades europeias, como Amsterdã, Bolonha e Madri, grupos comunitários se articulam para melhorar seus bairros. Nos Estados Unidos, o governo federal laça o programa das "Cidades Modelo", que auxiliou cidades e grupos comunitários para reabilitar áreas ocupadas por moradores de baixa renda (NOBRE, 2009). 
Autores como Bourdin (2001) definem a reabilitação como uma forma de intervenção urbana que privilegia o social e respeita dimensão local. Algumas dessas intervenções seguem o "Modelo de Bolonha", cujo objetivo foi recuperar a função social do patrimônio habitacional como um patrimônio integrado ao tecido social urbano que devia preservar os usos habitacionais. O caso de Bolonha foi emblemático, cuja prefeitura - dirigida pelo comunista Guido Fanti - elabora um programa de proteção da parte antiga da cidade com a manutenção da população pobre, com projetos de habitação de interesse social em edifícios históricos (NOBRE, 2009).

4. Revitalização: Em contraposição ao conceito anterior, a revitalização (palavra recorrente no discurso dos projetos de renovação urbana) representa uma estratégia global de incorporação dos negócios imobiliários na requalificação de áreas degradadas para lograr o repovoamento e a revalorização do espaço. Para Leite (2007), os projetos de "revitalização" segmentam certas áreas centrais das cidades históricas, levando para o aspecto cultural a exclusão social. Essas políticas se manifestaram nos anos 1980, quando com a crise do capitalismo e o surgimento do neoliberalismo provocou uma revisão da política urbana. As principais cidades do mundo começaram a competir pela captação de capitais e investimentos, para entregar as condições aos investidores de altos lucros, as prefeituras flexibilizam sua legislação, ou adotam formas como o planejamento estratégico ou o marketing urbano, constituindo o "empreendedorismo" urbano (HARVEY, 2007). Nesse período, as políticas urbanas para áreas centrais passam a ter um viés elitista, muitas vezes renovando todo o tecido urbano e social, provocando a expulsão da população de menor renda. Exemplos disto são os grandes projetos urbanos de construção de novos centros administrativos, de negócios, ou turismo como aconteceu em Barcelona, Londres e Nova York, entre outros (NOBRE, 2009).

5. Consumo cultural: O conceito de consumo cultural está relacionado com a ideia de sociedade de consumo no contexto de economias de mercado, e com padrões de consumo massificados. A cultura do consumo está ligada a valores, práticas e instituições fundamentais que definem a modernidade ocidental (SLATER, 2011). Em geral, é associado a três aspectos: 1) como produtos de consumo, ou ato de mercado de determinados bens; 2) como os destinatários dos produtos, os consumidores; e 3) como uma pratica de apropriação simbólica, de ressignificação e construção de identidades. 
Bourdieu (1990) define o consumo cultural como a relação entre padrões de participação e preferências culturais e ao pertencimento de classe. Para o autor o consumo cultural é uma das formas com que os grupos sociais se distinguem. Leite (2007), com base em Baudrillard e Canclini, define o consumo cultural como o conjunto de processos de apropriação e usos de produtos nos quais o valor simbólico prevalece sobre os valores de uso e de troca. O consumo cultural também implica intercambiar significados.

A dimensão de consumo é inserida no discurso político que justifica a maioria das intervenções do patrimônio que produzem elitização. Considerar o patrimônio cultural como mercadoria ressalta seu valor de troca por sobre seu valor de uso (LEITE, 2007). Leite (2007) menciona a necessidade de definir o patrimônio em função dos significados que possui para as pessoas, sendo que o principal elemento de um bem cultural é o uso dado pela sociedade. Para o autor, o valor de uso pode ser entendido em duas modalidades: primeiro como valor afetivo, relações subjetivas dos indivíduos com espaços, estruturas objetos; e segundo como valor pragmático, valores de uso percebido como qualidade.

6. Gentrificação simbólica: Gentrificação simbólica explica a maneira como os diferentes aspectos simbólicos de um espaço se agrupam política, econômica e socialmente como uma estratégia de deslocamento. Esses processos se relacionam diretamente com a reapropriação do patrimônio cultural por novos residentes e usuários atraídos pelas políticas de incentivo ao consumo (JANOSCHKA; SEQUERA; SALINAS, 2013).

Sequera (2013) relaciona a gentrificação simbólica com a produção cultural institucionalizada. Ele discute as consequências de longo prazo das requalificações, revitalizações e renovações urbanas sob uma perspectiva que interpreta essas intervenções como expressões de uma prática política neoliberal que procura implementar um modelo de conduta. Estudando o caso de Lavapiés no centro histórico de Madri, Sequera (2013) descobre como se impõem novos estilos de vida, agora fundamentados em praticas distintivas de consumo com a implementação de infraestrutura cultural e espaços comerciais.

No debate sobre gentrificação na América Latina, a gentrificação simbólica foi estudada em cidades como Buenos Aires, Cidade do México, Quito, Salvador da Bahia, 
Recife, Fortaleza, entre outros, e foi relacionada pelos investigadores a questões raciais e étnicas, ao aumento do turismo em lugares patrimoniais e a mecanismos de controle social em zonas revitalizadas (JANOSCHKA; SEQUERA; SALINAS, 2013). Para Casgrain e Janoschka (2013) as diferentes formas de gentrificação simbólica nos casos latino-americanos conectam-se com políticas neoliberais, que restauram o patrimônio arquitetônico nos centros urbanos para serem usufruídos por turistas, elites e as novas classes médias. Alguns autores denominam esses processos de "turismo gentrificação" ou "gentrificação comercial". Na maioria dos casos as políticas são desenvolvidas com a cooperação da UNESCO (Organização das Nações Unidas para a Educação, Ciência e Cultura) através de declarações de patrimônio mundial e implementando novos modelos de governança.

\footnotetext{
Uma das principais consequências destes processos se refere à expulsão de camelôs, e assim preparar as paisagens urbanas centrais para sua posterior gentrificação. Este deslocamento dos comerciantes - muitos deles de uma composição racial e étnica diferentes das classes medias e altas - apresenta uma série de poderosos símbolos que são o cenário da gentrificação, tendo em consideração que são as classes baixas, os comerciantes, quem são deslocados das ruas do centro da cidade em favor de um setor turístico em crescimento (CASGRAIN; JANOSCHKA, 2013, p.27).
}

Como descreve a citação, a revalorização do patrimônio arquitetônico nos centros das cidades muitas vezes serve para preparar a expulsão e a exclusão dos mais pobres que se haviam apropriado dessas áreas enquanto eram "desvalorizadas". A gentrificação simbólica acontece principalmente no espaço público com a institucionalização da produção cultural e comercial. Este aspecto é fundamental para entender a relação entre o público e o privado como expressão da natureza especulativa do capital na cidade contemporânea. A gentrificação simbólica seria oposta ao espaço público como parte de uma dominação maior da esfera pública pelos atores privados (JANOSCHKA; SEQUERA; SALINAS, 2013).

Para esta dissertação, a reconstrução da história urbana da Vila Planalto é feita por recortes temporais determinados pelas informações disponíveis como: pesquisas anteriores, registros documentais, relatos, dados censitários, e levantamentos de informações próprios. Essa reconstrução é feita para analisar as forças que atuam no processo de gentrificação e seus mecanismos de pressão, que poderiam provocar a troca da população original por outra de maior renda. 
As variáveis de análise, que derivam da teoria da gentrificação, são agrupadas nos aspectos socioeconômicos e o principal objetivo é avaliar a aplicação dos conceitos estudados. Algumas das principais variáveis e suas categorias são: usos de solo (percentual de usos comerciais e multifamiliares), valores do solo (incrementos nos preços de venda e aluguel), emprego e renda (percentual de trabalhadores qualificados, percentual de moradores com altas rendas), demográfica (incremento na população jovem), condição da propriedade (percentual de propriedades alugadas), tempo de residência (diminuição de moradores antigos), entre outras.

Os atributos destas categorias de análise são calculados em valores de moeda, números percentuais, ou índices próprios, que permitem comparações no tempo e com outras variáveis. Dados georreferenciados em Sistemas de Informação Geográficos (SIG) podem ser relacionados com categorias das outras teorias a serem utilizadas nesta dissertação. 


\section{Método de análise sintática do espaço}

A análise sintática do espaço é o método da TSE para prever e testar as possíveis relações entre o espaço e as pessoas. O método permite entender as respostas potenciais que a forma urbana poderia dar à sociedade. A metodologia estabelece conceitos e categoria de análise, bem como possíveis correlações, oferecendo ferramentas para entender e representar a forma do espaço urbano (MEDEIROS, 2006).

As aplicações da TSE são diversas, sendo útil no estudo e desenho de cidades, projetos urbanos, malhas viárias, sistemas de transporte, edifícios públicos, habitações, etc., podendo ajudar a predizer as relações entre os layouts espaciais e seus possíveis efeitos sociais, como a incidência no crime, fluxo de pedestres, tráfego de veículos, entre outros. Na análise sintática do espaço aspectos da configuração espacial são mensurados matematicamente e representados visualmente valorizados, permitindo quantificar e descrever a forma espacial e seus potenciais movimentos de pessoas.

Medeiros (2006) explica que as pesquisas com base na TSE sugerem três conceitos principais: 1) as medidas de caráter topológico se correlacionam com padrões do movimento de carros e pessoas, em aproximadamente $70 \% ; 2$ ) as propriedades das isovistas $^{6}$ são um modo de considerar como espaços abertos se relacionam com o comportamento social; e 3) representações dos layouts (seja como mapa axial, espaço convexo ou grafo de visibilidade) e análises topológicas (angulares) têm relação com a maneira como percebemos o espaço.

Com base nessas ideais gerais, entende-se que os espaços podem ser divididos em componentes e analisados por partes para compreender o sistema como um todo. As três técnicas de decompor analiticamente o espaço são: 1) isovista ou mapa de visibilidade é o campo de visão desde qualquer ponto específico para todos os pontos; 2) espaço axial ou mapa axial, representação linear do espaço, representa a malha viária a partir de possíveis caminhos retos; 3) espaço convexo, espaço vazio representado em um polígono onde todos os seus pontos são visíveis por todos os outros pontos do mesmo polígono.

\footnotetext{
${ }^{6}$ A isovista é um polígono representando em duas dimensões o campo de visão desde um determinado ponto no espaço. A partir das propostas de outros autores, Holanda (2012) entrega duas possíveis definições de isovista: 1) conjunto de pontos visíveis a partir de um ponto; e 2) polígono visual que descreve o campo visual de um observador.
} 
Nos aspectos configuracionais se desenvolverá a análise da forma espacial do caso de estudo. Nesta análise, serão utilizadas as teorias, os métodos e as ferramentas da Sintaxe Espacial para estudar as mudanças históricas na configuração urbana do local e a condição atual do espaço. Algumas categorias analíticas a utilizar correspondem ao conceito de mapa axial e de visibilidade.

As variáveis de análise derivadas do mapa axial são: Conectividade, Integração Global, Integração Local, Comprimento de linha, Inteligibilidade, e aspectos de visibilidade tais como: Conectividade visual, Controle visual e Integração visual. A continuação, definimos as categorias mais usadas da TSE que serão utilizadas nesta pesquisa.

1) Conectividade: expressa a quantidade de conexões existente em um eixo. A TSE explica como há uma associação entre a articulação da trama viária e os potenciais de acessibilidade para cada eixo do mapa.

2) Integração: é um dos conceitos mais utilizados em estudos de Sintaxe Espacial. A medida de integração ou Integração Global (Rn ou $\mathrm{HH}$ ) descreve o potencial de acessibilidade topológica de cada eixo para todo o sistema, onde "R" é o raio, "n" é o número de conexões e "HH" refere-se a Hillier e Hanson, fundadores da teoria. Os eixos mais integrados, representados com cores mais quentes, são aqueles que representam vias potencialmente mais permeáveis, mais acessíveis no espaço urbano e que possuem uma posição de controle. Holanda indica que, na literatura, termos como "raso" ou "simétrico" se utilizam como sinônimo de integrado, enquanto "profundo" ou "assimétrico" seriam sinônimos de "segregado" ou pouco "integrado". A medida de integração varia de 0 a $\infty$, quanto maior o número maior a integração.

3) Núcleo de integração: corresponde ao conjunto dos eixos mais integrados (vermelhos) do mapa axial. Medeiros (2006) aponta autores que definem o conceito nos textos sobre Sintaxe Espacial: Karimi dá o exemplo das cidades históricas inglesas, define o núcleo de integração como o grupo de linhas localizadas a um ou dois passos da linha mais integrada. De acordo com o autor, Hillier prefere seguir um padrão cromático, considerando como núcleo a principal agrupação de linhas vermelhas, laranjas e amarelas.

4) Inteligibilidade: na TSE, a medida de Inteligibilidade do mapa axial representa a correlação entre a conectividade e o valor de integração global dos eixos. A medida se 
expressa como coeficiente de determinação $\left(\mathrm{R}^{2}\right)$, ou coeficiente de Pearson (r), que indica a associatividade das variáveis entre si. A Inteligibilidade é interpretada como o potencial de se entender o sistema como um todo, ou como a facilidade para se orientar e localizar em uma malha viária. $\mathrm{O}$ conceito de inteligibilidade faz a relação entre uma medida global, a integração, e uma local, a conectividade (HOLANDA, 2002). Um sistema com poucas linhas globais (que atravessem o sistema completo) pode relacionar-se com uma baixa inteligibilidade. Ao contrário, um sistema de ruas globais intensamente cruzadas por outras tem alta inteligibilidade. A medida vai de 0 a 1 , quanto mais próximo de 1 maior a inteligibilidade.

5) Controle: indica uma posição de dominância de um eixo sobre outros. A medida de controle sugere os eixos topologicamente dominantes de um sistema. Um eixo com valor de controle alto possui grande quantidade de conexões com linhas de baixa conectividade. A variável mede quanto um eixo controla o acesso aos eixos que cruzam com ele. Os eixos com maior controle são representados com cores quentes (linhas vermelhas) e os eixos com menor potencial de controle em cores frias (linhas azuis).

6) Escolha: medida que representa quantas vezes um eixo é atravessado pelos potenciais percursos em relação aos caminhos topológicos mais curtos. Publicações demonstram que a medida revela a hierarquia do sistema viário dentro de uma estrutura urbana, por ressaltar as prováveis rotas.

A TSE permite a interpretação qualitativa e quantitativa do espaço. A análise configuracional mensura fatores da forma urbana e os traduz em mapas visuais (apreciação visual, qualitativa) e medidas numéricas (apreciação estatística, quantitativa) (MEDEIROS, 2006). Nesta pesquisa, os atributos que caracterizam as categorias da Sintaxe Espacial são classificados em função de porcentagens ou medidas numéricas.

As bases de dados obtidas de informações oficiais ou levantamentos em terreno, foram inseridas no aplicativo ArcMap (SIG), permitindo o cruzamento da informação entre os valores dos mapas axiais com a localização georreferenciada de informações cadastrais. Os valores são sistematizados em tabelas de Excel, gerando as relações entre variáveis dependentes e independentes de cada grupo, o que permite obter, por meio de gráficos de dispersão, o grau de correlação ou dependência entre variáveis. 
O objetivo é estabelecer relações entre aspectos configuracionais e da dinâmica urbana do bairro, possibilitando a quantificação das correlações entre acessibilidade espacial e usos do solo, e também da correlação entre controle do espaço e altura das edificações.

Para quantificar essas relações, com base em MEDEIROS (2006), adotamos o valor de "r", coeficiente de correlação de Pearson, que mostra uma medida da relação linear entre duas variáveis quantitativas aleatórias. O índice varia entre 1 e -1 . Quando $\mathrm{r}=1$ existe uma correlação positiva perfeita, ou total dependência das variáveis, denominada relação direta, quando uma aumenta a outra também aumenta. Ao contrário, quando $\mathrm{r}=-1$ existe uma correlação negativa perfeita, indica dependência total em uma relação inversa, quando uma delas aumenta a outra diminui. Se $r=0$ não existe correlação, portanto quanto mais próximo de 0 menor será a relação.

$\mathrm{O}$ coeficiente de determinação ou índice $\mathrm{R}^{2}$ corresponde ao quadrado do coeficiente de Pearson e mede a proporção da correlação total entre uma variável dependente em relação à variável independente. Se a proporção é igual a 0 , a variável não tem relação, se o valor é igual a 1 a relação é total. Quanto mais próximo de 1 mais forte será a relação entre as variáveis.

Tabela 1: Avaliação dos valores dos Coeficientes de determinação, $\mathrm{R}^{2}$, e coeficiente de Pearson, $\mathrm{r}$.

\section{CLASSIFICAÇÃO}

\begin{tabular}{|l|c|c|}
\hline Inexistente & 0,0 a 0,09 & 0,0 a 0,008 \\
\hline Pequena & 0,1 a 0,29 & 0,01 a 0,08 \\
\hline Moderada & 0,3 a 0,49 & 0,09 a 0,24 \\
\hline Grande & 0,5 a 0,69 & 0,25 a 0,48 \\
\hline Muito Grande & 0,7 a 0,89 & 0,49 a 0,80 \\
\hline Quase Perfeita & 0,9 a 0,99 & 0,81 a 0,99 \\
\hline Perfeita & 1 & 1 \\
\hline
\end{tabular}

Fonte: (COHEN, 1988 apud MEDEIROS, 2013).

A Tabela 1 apresenta a Escala de Cohen, que explica a intensidade da correspondência dos valores " $r$ " e " $\mathrm{R}^{2}$ " (MEDEIROS, 2006). Esta classificação será adotada para avaliar, de inexistente a perfeita, os coeficientes de determinação. 


\section{Método etnográfico}

A pesquisa etnográfica é um método de investigação em que se apreende o modo de vida de uma unidade social específica, por meio da observação direta e da realização de entrevistas. A etnografia, que foi desenvolvida por antropólogos e sociólogos, destacando-se os trabalhos de Bronislaw Malinowski e Ervin Goffman, é um processo sistemático de aproximação a uma situação social, estudada em seu próprio contexto, que se interessa pelo que as pessoas fazem, como se comportam e interagem, para entender seus valores, motivações e intenções (MURILLO, 2011).

A etnografia como método de investigação social trabalha com várias fontes de informação. $\mathrm{O}$ investigador participa, abertamente ou encoberto, da vida cotidiana de pessoas durante um tempo relativamente extenso, observando o que acontece, colhendo dados acessíveis para dar resposta aos temas que se estuda. Tanto o trabalho de campo como a observação participante e as entrevistas são fundamentais para identificar os códigos que se escondem por trás das aparências dos investigados.

A antropologia urbana é uma ciência própria da cidade, do espaço urbano, que dialoga com outras disciplinas como: geografia, sociologia, arquitetura e urbanismo, pois trabalha com temas como o direito à cidade e a ocupação do espaço público. Como disciplina, a antropologia urbana utiliza a etnografia como principal método de pesquisa, estudando as especificidades das relações humanas que dialogam com o espaço da cidade, suas apropriações e significados. O foco da etnografia são as relações sociais, a cidade como variável independente, em outras palavras, estuda o impacto da cidade nas pessoas.

À continuação descrevemos alguns conceitos utilizados em pesquisas etnográficas que são pertinentes nesta dissertação.

1) Cotidiano: em palavras simples, o cotidiano é aquilo que acontece todos os dias. Quando não acontece nada diferente do comum (GIANNINI, 2013). Poderíamos defini-lo como as ações diárias que constituem uma rotina. Para Giannini, o cotidiano é uma categoria, "um modo de ser de um ser que, vivendo, se repete silenciosamente e cada dia se aprofunda em si mesmo" (GIANNINI, 2013, p.29).

O círculo da vida cotidiana começa no domicílio, lugar da habitação, segue pela rua para o trabalho, lugar dos afazeres, para voltar pela rua ao domicílio novamente. $\mathrm{O}$ domicílio, a casa, representa o espaço privado que nos separa do mundo público, 
transformando-se em um regresso a si, como um símbolo da singularidade, ao contrário da rua, que é símbolo da universalidade. Fora do domicílio começa o espaço público, a vizinhança, o bairro, até perder-se no anonimato da cidade.

Humberto Giannini resgata as relações espaciais entre os lugares topográficos do tempo circular civil que constroem a experiência comum, ressaltando a importância do domicílio, do trabalho, da rua, da praça e do bar, como os lugares de manutenção e transgressão da rotina cotidiana. Michel de Certeau (1996; 2008), por sua parte, identifica o bairro como o espaço social que reúne esses elementos do cotidiano. $\mathrm{O}$ bairro agrupa também o espaço e o tempo civil, destacando-se como o lugar da experiência comum, de comunicação e de comunidade.

O cotidiano é aquilo que nos é dado cada dia, nos pressiona dia após dia, nos oprime, pois existe uma opressão do presente. (...) O cotidiano é aquilo que nos prende intimamente, a partir do interior. É uma história a meio-caminho de nós mesmos, quase em retirada, às vezes velada. (CERTEAU; GIARD; MAYOL, 2008, p.31)

De Certeau (2008) organiza a vida cotidiana na articulação de dois aspectos. Por um lado, os comportamentos ou condutas, visíveis no espaço social da rua através de códigos e ritmos próprios dos habitantes desse espaço, o que valoriza ou não aquele espaço público. Por outra parte, os benefícios simbólicos que se espera obter segundo a forma de comportamento no bairro. Esses significados simbólicos são interpretados pelo pesquisador por meio do sentido do discurso, no qual o usuário relata as iniciativas e intenções de suas ações.

2) Bairro: Michel de Certeau, em seu livro $A$ invenção do cotidiano, estuda os modos de vida na cidade, especificamente no bairro da Croix-Rousse em Lyon, com o objetivo de descobrir as práticas culturais dos usuários da cidade no espaço de seu bairro. Para isso, ele analisa duas problemáticas, primeiro, a sociologia urbana do bairro, e segundo, a análise socioetnográfica da vida cotidiana. Essas duas perspectivas se inserem no ambiente urbano do bairro, para evidenciar as práticas diárias dos moradores e investigar como se relacionam com o espaço público em que se desenvolvem. $\mathrm{O}$ autor estuda as relações entre objetos, especificamente "o vínculo que une o espaço privado ao espaço público” (CERTEAU et al., 2008, p. 38). Para ele, essas relações entre objetos constituem uma das condições para a vida cotidiana no espaço urbano, conformando de maneira crucial a noção de bairro: em um bairro não existe o público sem o privado, são interdependentes. 
Segundo De Certeau (2008), o bairro é o lugar de manifestação do "engajamento" social, ou seja, a arte de conviver com os outros ligados pela proximidade topográfica e pela repetição de condutas. Esses dois elementos, proximidade e repetição, são regulados pelo contrato implícito da conveniência, que representa um compromisso pelo qual cada habitante contribui à vida coletiva, com o fim de manter seus benefícios simbólicos e manter a coexistência do bairro.

Essas relações de conveniência explicam o conceito de "prática cultural", definido pela combinação de elementos cotidianos concretos ou ideológicos, que derivam de uma tradição social e que são exercidos dia a dia. A prática cultural representa um sistema de valores estruturantes que organiza a vida cotidiana, sendo decisiva para a identidade dos indivíduos e do grupo, na medida em que essa identidade permite a cada um assumir seu lugar dentro das relações sociais que acontecem em um ambiente determinado (CERTEAU; GIARD; MAYOL, 2008).

O bairro compõe uma parcela do espaço urbano onde acontecem as práticas culturais; é o ambiente onde acontecem os fenômenos sociais que permitem aos indivíduos reconhecer-se. Portanto, é possível apreender o bairro como uma porção do espaço público e privado dentro da cidade, cenário de convivências e usos cotidianos. No espaço do bairro se organizam coletivamente trajetórias individuais e fica à disposição de seus usuários lugares que atendam às necessidades cotidianas. (CERTEAU; GIARD; MAYOL, 2008, p.46)

Para De Certeau (2008), entre as dimensões que definem um bairro estão suas características históricas, estéticas, topográficas, socioprofissionais, entre outras. O autor se apoia na definição de Henri Lefebvre: "o bairro é uma porta de entrada e de saída entre espaços qualificados e o espaço quantificado" (CERTEAU; GIARD; MAYOL, 2008, p. 41). O domínio do bairro remete à noção do tempo e do espaço por onde os usuários podem se deslocar a pé, em consequência, corresponde a uma parte da cidade com limites definidos pelos vínculos significativos entre as residências e o espaço público onde se localizam.

O bairro é uma noção dinâmica, que necessita de uma progressiva aprendizagem, que vai progredindo mediante a repetição do engajamento do corpo do usuário no espaço público até exercer aí uma apropriação. (CERTEAU; GIARD; MAYOL, 2008, p. 42) 
O espaço do bairro representa uma continuidade entre a intimidade da residência e o anonimato da cidade, manifestando-se como uma prolongação da habitação. Podemos inferir das palavras do autor que o bairro é o resultado das relações entre os cheios (espaço privado) e vazios (espaço público) e seus habitantes, que outorgam significados e valores para aquela configuração a partir de suas trajetórias e práticas cotidianas no meio urbano. Aí se reúnem as condições que favorecem a convivência dos indivíduos e seu espaço: lugares, trajetos, relações de vizinhança, comércio etc., o que produz e organiza a sociedade tornando o espaço urbano um objeto não só de conhecimento, mas também um lugar de reconhecimento (CERTEAU; GIARD; MAYOL, 2008).

Para Castells (2006) é evidente a existência de uma diferenciação fracionária do espaço urbano atrelada à divisão social do trabalho, porém não é nítida a existência de unidades residenciais ecologicamente delimitadas que constituam especificidade. $\mathrm{O}$ autor faz menção aos postulados da Ecologia Humana sobre as "áreas naturais" definidas como: unidades espaciais limitadas por fronteiras naturais, habitados por uma população homogênea de valores específicos; e como, unidades espaciais habitadas por uma população que possui uma estrutura de relações simbólicas internas. $\mathrm{O}$ autor relembra da diferencia entre aldeia, unidade de vizinhança, vila e bairro. De nosso interesse, uma vila é definida como um agrupamento de habitações associadas a uma atividade que constituem uma comunidade; também se define como uma extensão espacial concreta a escala de pedestre, com equipamentos coletivos. O bairro além dos equipamentos coletivos acessíveis ao pedestre constitui uma subcultura dentro da estrutura social podendo chegar a institucionalizar certa autonomia local.

3) Lugar: Leite (2007) em seu livro Contra-usos da cidade define os lugares como "demarcações físicas e simbólicas no espaço, cujos usos os qualificam e lhes atribuem sentidos de pertencimento, orientando ações sociais e sendo por estas delimitadas reflexivamente" (LEITE, 2007, p. 35). O lugar representa um espaço para onde convergem experiências compartilhadas. Um lugar é um espaço de representação construído por práticas sociais e usos cotidianos. Os lugares urbanos têm fronteiras, que são construídas socialmente e negociadas cotidianamente em um processo de interações públicas, onde emergem conflitos.

Para Leite $(2002,2007)$ esses lugares, ou "territórios de subjetivação", não sempre acabam em arranjos espaciais restritivos da vida pública, ou seja, nos espaços das paisagens urbanas elitizadas criam-se lugares e apesar das barreiras e restrições existe 
vida pública. “(...) Os lugares contribuem para a construção prática do espaço público, tornando-o inteligível.” (LEITE, 2007, p. 289). A construção de lugares é o início do processo de construção de potenciais espaços públicos.

4) Usos | Contra-usos: segundo o autor, os usos correspondem aos sentidos da política urbana oficial, em contraste com os contra-usos, que seriam os contrassentidos, reflexos de ações informais. O uso envolve duas dimensões: 1) Valor afetivo: relações subjetivas da sociedade com os espaços, estruturas, objetos que geram processos identitários ou da memória social. 2) Valor pragmático: valores de uso percebidos como qualidades. Como transgressões a essas dimensões, os contra-usos representam ruídos visuais, subversões do enobrecimento, que se manifestam de maneira silenciosa e aleatória, provocando desconforto nas requintadas paisagens.

Os contra-usos desses espaços, que imprimem ruídos visuais à paisagem enobrecida, muitas vezes impõem formas de negociação, acompanhadas pelas demandas de pertencimento e reivindicações relativos a diferentes lugares. (LEITE, 2007, p.250)

Alguns exemplos mencionados por Leite são os moradores de rua e vendedores informais do Bairro do Recife. Assim, diversos personagens são parte dos contra-usos, ruídos que contra enobrecem a paisagem urbana da gentrificação, que volta os espaços centrais das cidades para o turismo e consumo do patrimônio.

Os usos e contra-usos sociais de um espaço subvertem cenários monumentais enobrecidos. Leite (2007) explica como o Largo do Marco Zero passou a ser alvo de manifestações sociais e políticas da cidade, tornando-se um espaço central e de visibilidade pública. Os atos públicos entregavam carga simbólica ao espaço, revelandose a subversão de seus usos, chegando além do consumo e lazer e alcançando uma dimensão política.

5) Espaço público: para Leite (2007) é uma categoria sociológica constituída pelas práticas que dão sentidos diferenciados e estruturam lugares. Em seu livro, define-se a noção de espaço público da seguinte forma:

(...) entende-se que uma noção de espaço público requer, para qualificar como públicos determinados espaços urbanos da vida contemporânea, uma inserção conceitual de mão dupla entre espaço e sociabilidade pública. Implica, portanto, relacionar dois processos interdependentes, que concorrem simultaneamente para uma única direção: a construção social do espaço, 
enquanto produto e produtor de práticas sociais; e a construção espacial da sociabilidade pública, enquanto produto e produtor das espacializações da vida social. (LEITE, 2007, p.196)

O espaço público está conformado pelo espaço e pelas ações que nele acontecem, em uma convergência entre uma sociabilidade pública e os espaços que se constroem. Os lugares do espaço público são demarcações socioespaciais da diferença ou "singularidades que demarcam contextos de ação e espaços simbolicamente convergentes" (LEITE, 2007, p.24). Algumas características de um espaço potencialmente público seriam: 1) espaço urbano, aberto e de propriedade púbica; 2) espaço de significados, espaço semiótico das relações entre representação e poder; 3 ) esfera pública, cidadãos engajados politicamente, manifestações de certas formas de solidariedade social.

6) Classe social: Park, em 1915, mencionava que na cidade as ocupações (profissões e ofícios) pareciam se reagrupar em classes. Holanda (2013) diferencia classe social como categoria da divisão social do trabalho, de classes de renda ou faixas de renda, e de classes profissionais, que corresponderia às ocupações. $\mathrm{O}$ autor propõe como hipótese um sistema dividido em quatro classes: 1) grande burguesia (grandes empregadores); 2) pequena burguesia (pequenos empregadores); 3) classe média (dirigentes do setor público, prestadores de serviço especializados); e 4) trabalhadores manuais ou classe trabalhadora (prestadores de serviço não especializado).

As categorias analíticas em antropologia urbana devem ser flexíveis e considerar os aspectos locais e os elementos que os próprios habitantes possam entregar.

1) Vizinhança: Para Park (1999), é uma parte distintiva da cidade com sentimentos particulares de sua população. Corresponde a uma localidade com sua própria sensibilidade, tradições e história. No local, existiria uma continuidade dos processos históricos e a vida teria um ritmo próprio. A vizinhança é uma unidade social de organização da vida urbana por proximidade e contato (PARK, 1999).

2) Guetos: área de segregação e isolamento racial, colônias que preservam e acentuam a intimidade e solidariedade dos grupos locais e vizinhais. Misturam-se afetos com um sentimento de classe e raça na organização social (PARK, 1999).

3) Região moral: áreas onde um código moral prevalece entre os indivíduos. Nem sempre é um lugar de residência, pode ser um ponto de encontro ou reunião (PARK, 
1999).

4) White-collar: Wirth denomina esta categoria da seguinte forma: "A classe dos 'White-collar', que compreende os empregados do comércio, intelectuais e profissionais" (WIRTH, 2005, p. 13), também podem ser funcionários públicos, foram chamados assim pelos colarinhos das camisas que vestiam. Esse grupo pertencente tradicionalmente às classes médias pode ser resumido como "trabalhadores simbólicos" nos termos de Giddens (HOLANDA, 2013).

5) Contra-gentrificação: Para Holanda (2013) apesar da ordem que domina a cidade, existem fissuras urbanas, que podem ser físicas ou podem ser ações das pessoas nos espaços. A esses "ruídos visuais" Leite (2007) chama de contra-usos ou conflitos sobre a ordem que se tenta impor sobre o território.

As categorias descritas acima representam variáveis qualitativas de pesquisa, ou seja, seus atributos não são mensuráveis numericamente e se definem por suas qualidades, permitindo sua classificação e estratificação. De modo geral, podemos identificar as variáveis por sua presença ou ausência no local, e em caso de presença, reconhecer suas características. É interessante estabelecer algumas possíveis relações entre categorias de diferentes teorias, como por exemplo: presença/ausência de contrausos $x$ controle; ou, presença/ausência de white-collar x usos do solo.

\section{Técnica de levantamento de dados}

As técnicas e as categorias de análise devem ser flexíveis e mudaram durante o desenvolvimento do trabalho de campo, que é um caminho que se faz a pé (SEQUERA, 2013), ou seja, pode mudar de direção e se traça andando pelo bairro. O mais importante da gentrificação são as consequências do processo (LEES; SLATER; WYLY, 2008), portanto, para estudar as consequências é necessário localizar o fenômeno no espaço e no tempo. A gentrificação gera deslocamento, o que afeta as pessoas em situações mais

precárias, por isso a pesquisa deu espacial atenção ao trabalho em terreno, com a intenção de situar as pessoas no centro do fenômeno espacial.

As técnicas específicas de recopilação de informações são: entrevistas a atores sociais, revisão documental e de expedientes, e enquetes nos domicílios. Técnicas de pesquisa estão relacionadas com os objetivos, e são entendidas como estratégias ou 
táticas para estudar e aplicar os métodos. Para o levantamento de dados foram utilizadas ferramentas como desenhos, mapas e questionários, além de gravadora de voz e fotografias, e para a sistematização dos dados se utilizaram softwares computacionais como: Autocad, ArcMap (SIG), Excel etc.

\section{Técnica do mapa axial}

As técnicas utilizadas nesta análise são: a representação linear do espaço ou mapa axial e o geoprocessamento (informações cadastrais referenciadas geograficamente). $\mathrm{O}$ mapa axial é a forma de representação configuracional que revela a acessibilidade da malha viária. Na representação linear, a construção dos eixos é obtida traçando-se sobre a malha viária a menor quantidade de linhas retas que representam as potenciais possibilidades de movimento de veículos e pedestres.

Para a análise das transformações urbanas, a construção dos mapas axiais da Vila Planalto foi realizada sobre as fotografias áreas disponibilizada pela TERRACAP ${ }^{7}$ desde o ano 1965 até 2012, atualizadas com informações de Google Earth. Na Figura 6 aparecem os recortes que foram selecionados $(1965,1975,1980,1986,1991,1997$, 2003 e 2012) por apresentarem subsídios suficientes para a construção dos mapas axiais, e também por serem períodos bem distribuídos no tempo. Não foi possível obter informações suficientes para elaborar os mapas dos acampamentos originais.

Os mapas foram desenhados no software Autocad, em formato DXF, tendo como base as fotografias aéreas em escala (Figura 6). O desenho foi elaborado partindo da imagem mais nova (2012) para a mais antiga (1965). A representação linear dos sucessivos mapas é obtida apagando-se e modificando-se os eixos do mapa anterior. Em razão das mudanças na composição da Vila Planalto, foram interpretados todos os caminhos identificados nas fotografias, e consideramos os eixos dentro e fora do polígono de tutela, abarcando a borda da Vila.

\footnotetext{
7 Durante a construção de Brasília a Terracap foi um departamento imobiliário da Companhia Urbanização da Nova Capital (Novacap). Em 1972 é criada como uma empresa pública com o nome de Companhia Imobiliária de Brasília. Desde 1997 é transformada em Agência de Desenvolvimento do Distrito Federal.
} 


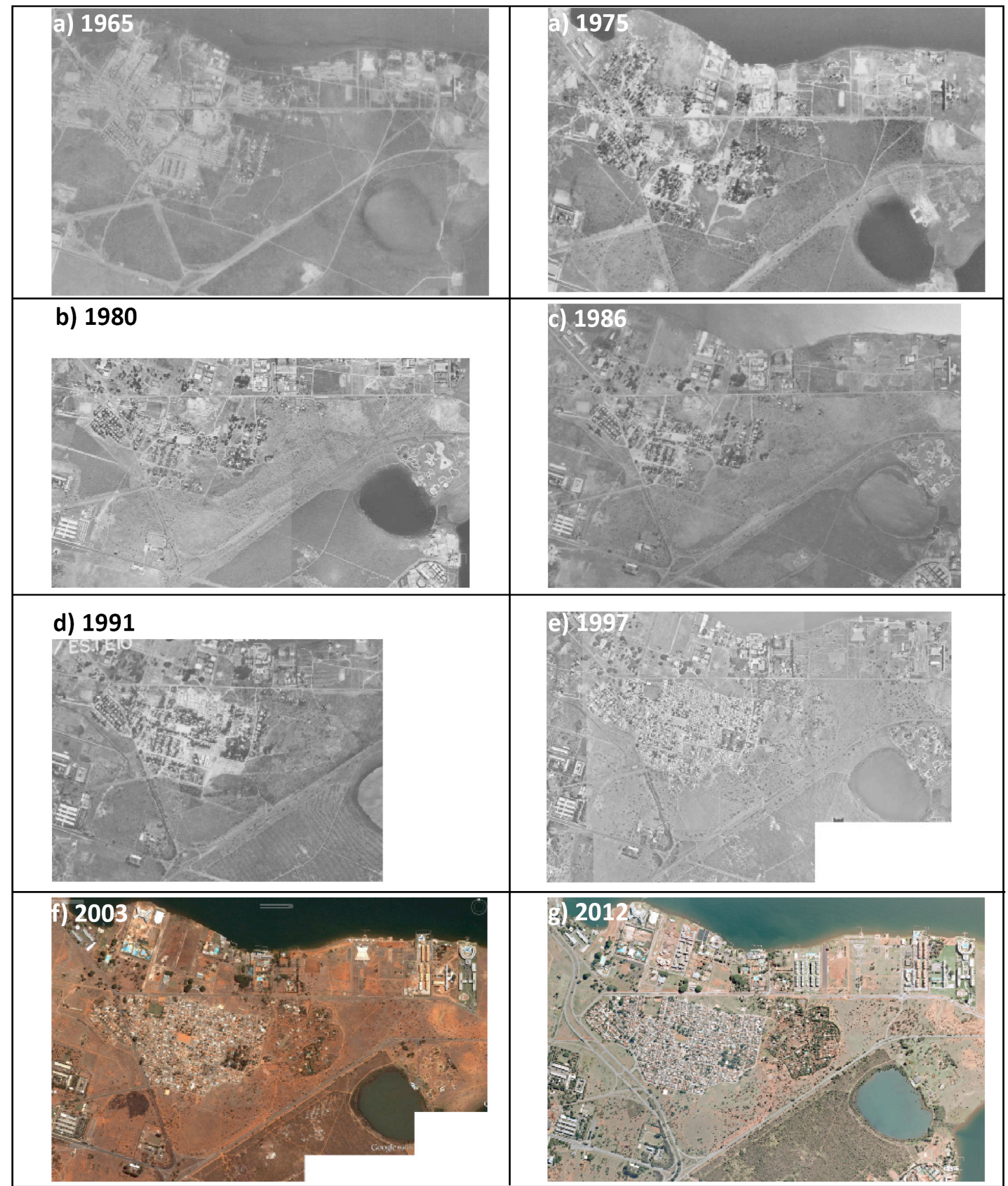

Figura 6: Seleção das fotografias aéreas da Vila Planalto (1965-2012).

Fonte: Google Earth e TERRACAP. 
Esses oito mapas gerados foram processados no software Depthmap. Com os resultados obtidos, procuramos avaliar o processo de transformação urbana na Vila Planalto, utilizando os valores e os mapas axiais na elaboração de tabelas e posteriormente gráficos que expliquem as tendências da configuração urbana.

Para a análise configuracional da atual Vila Planalto, a representação linear foi construída com base no levantamento aerofotogramétrico feito pela empresa Topocart, a pedido da TERRACAP no ano 2013. Esse levantamento, disponível em formato Autocad, foi utilizado para, primeiro, demarcar as ilhas espaciais ou barreiras ao movimento (representadas em cor cinza na Figura 7) e, segundo, para traçar os eixos da malha viária interna do bairro (líneas vermelhas na Figura 7).

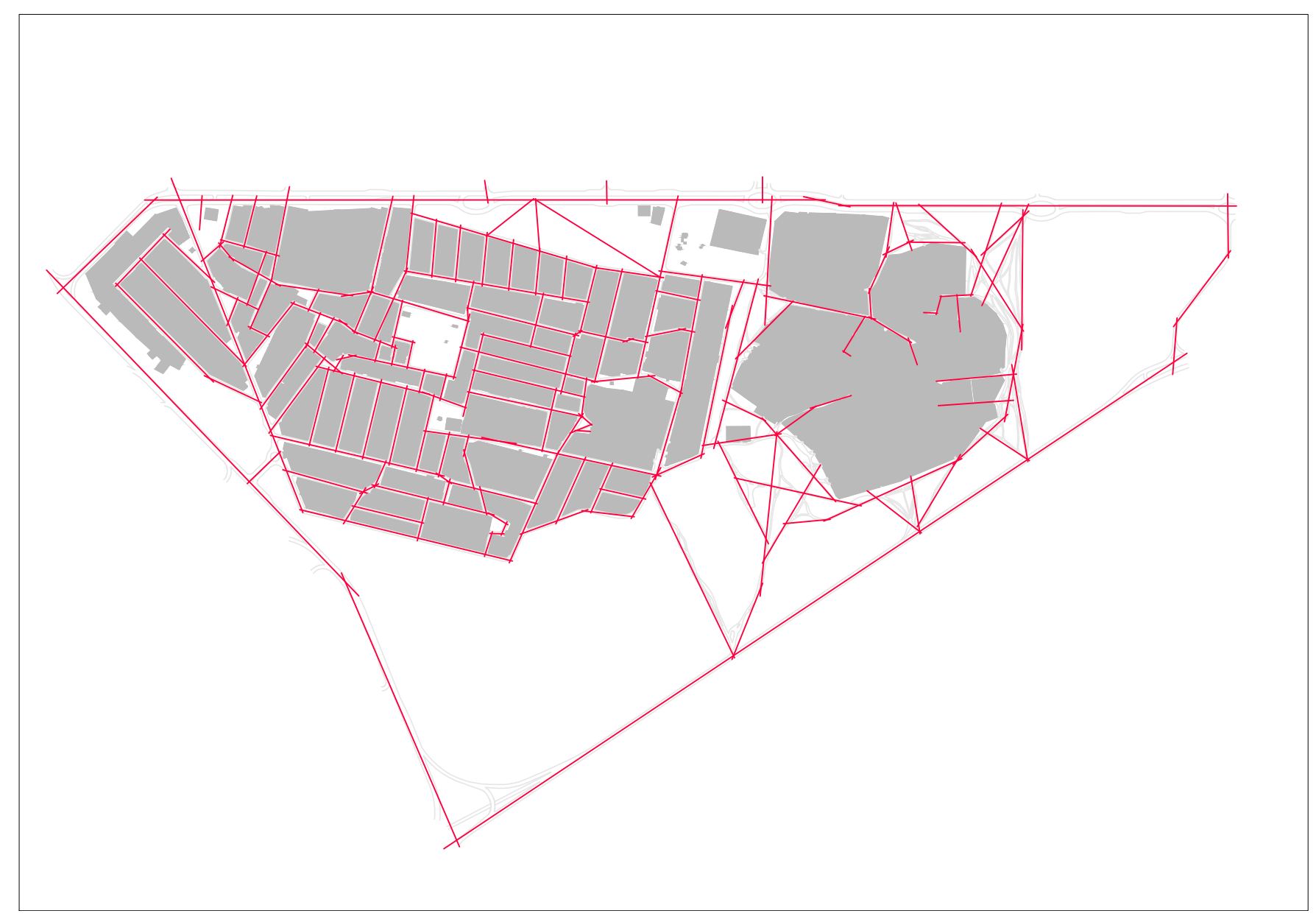

Figura 7: Mapa axial da Vila Planalto em 2013. Em vermelho o traçado dos eixos e cinza as barreiras ou ilhas espaciais. Fonte: Elaboração própria. 
Em consideração ao tipo de análise a desenvolver, não comparativo e focado no espaço interno do bairro, optamos por traçar as linhas retas de forma mais simples que nos mapas históricos. Elimina-se a borda e representa-se apenas os eixos dentro da área de tutela, como se observa na figura 5 .

Segundo Medeiros (2006), as etapas metodológicas podem ser classificadas da seguinte forma: primeira etapa, representação gráfica do espaço a estudar; segundo, análise por meio dos aplicativos específicos; e finalmente, os dados obtidos são correlacionados com outras variáveis de análise. Como se observa na figura 8 , o mapa axial processado no software Depthmap indica, com uma escala cromática, os potenciais de integração, acessibilidade ou permeabilidade. Os eixos mais integrados (Figura 8), permeáveis e accessíveis no sistema são representados com as cores quentes (vermelho) até os eixos menos acessíveis, representados com as cores mais frias (azul) (BARROS; MEDEIROS; MORAIS, 2009).

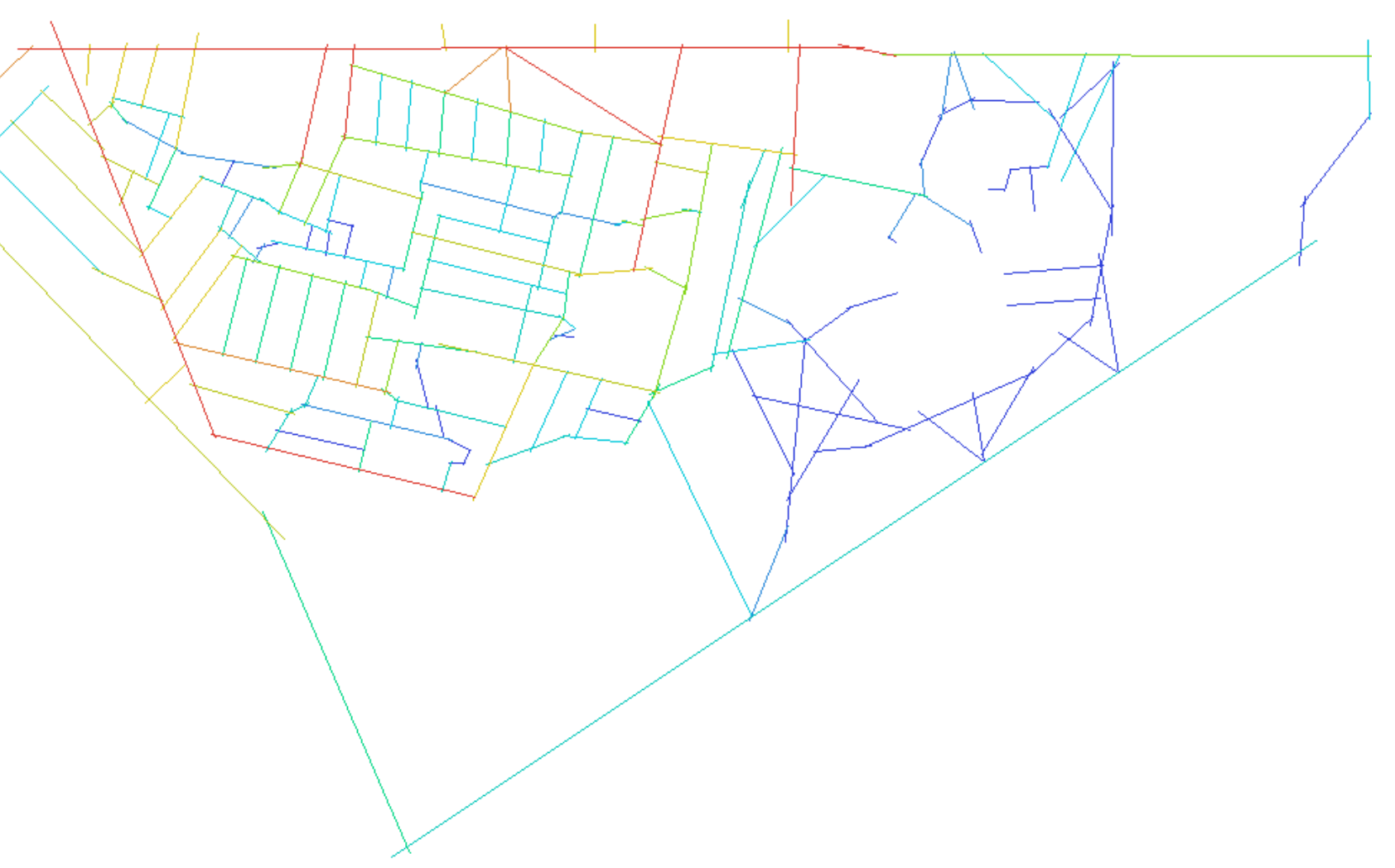

Figura 8: Mapa axial de Integração Global - Rn (HH) na Vila Planalto, 2013.

Fonte: Elaboração própria. 
Os principais instrumentos utilizados para este trabalho derivam das categorias de análise proposta. São três instrumentos ou grupos de variáveis: 1) Variáveis de análise resultantes do Mapa Axial - Conectividade, Comprimento médio de linha, Quantidade de linhas por $\mathrm{km}^{2}$, Integração (Raios n, 3, 6 e 9), Inteligibilidade, e Controle; 2) Variáveis provenientes do Mapa de Segmento - Integração e Escolha (Raios 100, 200, 400, 800, 1600, 3200m); 3) Variáveis resultantes de informações cadastrais - Área da Mancha Urbana e Área do Lote.

\section{Técnica de observação participante}

$\mathrm{Na}$ disciplina arquitetura e urbanismo a utilização de técnicas nativas da antropologia urbana impõe desafios. Carlos Nelson Ferreira dos Santos, arquiteto e antropólogo, escreveu sobre a relação entre essas disciplinas num artigo chamado "Como e quando pode um arquiteto virar um antropólogo". O autor expressa que não é possível falar da realidade sem ir lá onde ela está e vivê-la (SANTOS, 1980). A partir de sua experiência trabalhando em favelas descreve como começou a perceber ordens e códigos presentes do ambiente através do trabalho de campo.

De observador de padrões e arranjos dos espaços públicos e privados, fui me transformando em observador das inter-relações sociais e das redes de significados. (SANTOS, 1980, p. 42)

Santos comenta que estava se transformando em um "antropoteto" ou "arquipólogo" e descreve o aporte da antropologia para o planejamento urbano. O autor diz que procura o lugar do urbano na cultura capitalista, que essa seria a verdadeira “questão urbana" do antropólogo.

Algumas das ferramentas mais comuns utilizadas pelo método etnográfico são: a) observação: consiste em registrar o que acontece e descrever com detalhes; b) observação participante: quando se faz parte da comunidade que se observa; c) conversações formais e informais, entrevistas abertas, questionários etc.; d) histórias de vida: quando se quer dar uma visão mais íntima de personagens especiais, faz-se um seguimento de seu cotidiano ou da trajetória de vida; e) estudos de casos: descrições de uma unidade de amostra, podendo ser uma pessoa, um grupo ou uma organização. Para o desenvolvimento da análise do modo de vida utilizamos a observação participante, conversas e entrevistas. 
O procedimento da pesquisa etnográfica foi dividido em quatro etapas. Uma primeira etapa de preparação, desenho e planejamento da etnografia, onde foi necessária a recopilação de informações e a seleção de casos ou determinação do tamanho da amostra. A segunda etapa corresponde a trabalho de campo, recopilação dos dados, realização da observação participante e seu registro, por meio de gravações de áudio ou audiovisuais, fotografias, desenhos, descrições escritas etc. A terceira etapa é analítica, transcrição e processamento da informação e a sistematização dos dados. A última etapa é a informativa, elaboração do texto com as interpretações e achados.

É importante ser consciente que na prática o trabalho de campo não é fácil, devido às relações de poder entre os membros de grupos sociais. Cada resposta é o resultado de uma interação social específica e a maioria das respostas está determinada pela posição e a filiação do pesquisador e das pessoas entrevistadas.

As formas de representação possíveis são diversas, mas para esta pesquisa nos concentraremos na representação mediante fotografias, mapas, plantas, além de descrições escritas derivadas de gravações de áudio.

As informações se relacionam com a teoria e o problema. Como queremos identificar o bairro como um modo de vida, a etnografia deve objetivar conhecer a organização social do bairro e seus cotidianos. Nesta pesquisa, priorizamos a observação participante do cotidiano no bairro e realizamos entrevistas a residentes e usuários do espaço público. 
Quadro 2: Resumo dos aspectos teóricos.

\begin{tabular}{|c|c|c|c|}
\hline TEORIAS & Gentrificação & Sintaxe Espacial & Ecologia Humana \\
\hline Itens de conhecimento & $\begin{array}{l}\text { Transformações urbanas em } \\
\text { bairros centrais com } \\
\text { elitização e expulsão de } \\
\text { moradores mais pobres. }\end{array}$ & $\begin{array}{lr}\text { Relação } & \text { entre } \\
\text { propriedades } & \\
\text { configuracionais } & \text { do } \\
\text { espaço e } & \text { seu } \\
\text { funcionamento. } & \end{array}$ & $\begin{array}{l}\text { A cidade como produto da } \\
\text { natureza humana e como } \\
\text { laboratório social. }\end{array}$ \\
\hline Formulações teóricas & $\begin{array}{l}\text { Fenômeno influenciado pelo } \\
\text { modelo } \\
\text { desenvolvimento. } \\
\text { enfoques: 1) na demanda: } \\
\text { foco no consumo e } \\
\text { mudanças culturais; 2) na } \\
\text { oferta (rent gap): foco na } \\
\text { acumulação de renda } \\
\text { urbana. }\end{array}$ & $\begin{array}{l}\text { Leis que relacionam o } \\
\text { objeto construído e a } \\
\text { sociedade: 1) leis do } \\
\text { objeto, 2) leis da } \\
\text { sociedade para forma } \\
\text { urbana, 3) leis da forma } \\
\text { urbana para a sociedade, } \\
\text { 4) leis da sociedade em si. }\end{array}$ & $\begin{array}{lcr}\text { Sociologia } & \text { do espaço: } \\
\text { modelos } & \text { espaciais para } \\
\text { explicar o crescimento das } & \\
\text { cidades. } & \text { Cidade: } & 1 \text { ) } \\
\text { estrutura } & \text { física, } & 2 \text { ) } \\
\text { organização } & \text { social, } & 3 \text { ) } \\
\text { conjunto de atitudes } & \text { e } \\
\text { ideias. } & & \end{array}$ \\
\hline Campo de reflexão & $\begin{array}{ll}\text { Estratégias } & \text { de } \\
\text { reestruturação urbana } & \text { na } \\
\text { cidade contemporânea. } & \end{array}$ & $\begin{array}{l}\text { Relações entre arquitetura } \\
\text { e comportamentos. } \\
\text { Reflexão sobre os padrões } \\
\text { de encontro social no } \\
\text { espaço. }\end{array}$ & $\begin{array}{l}\text { Relações entre o meio } \\
\text { urbano e o comportamento } \\
\text { humano. }\end{array}$ \\
\hline Axiomas & $\begin{array}{l}\text { A gentrificação, processo } \\
\text { relacionado aos mercados } \\
\text { imobiliários, constitui um } \\
\text { retorno do capital financeiro } \\
\text { aos centros urbanos. }\end{array}$ & $\begin{array}{l}\text { O espaço socialmente } \\
\text { organizado é função das } \\
\text { formas de solidariedade } \\
\text { social. }\end{array}$ & $\begin{array}{l}\text { As grandes cidades são um } \\
\text { laboratório } \\
\text { comportamentos coletivo } \\
\text { que estão em constante } \\
\text { conflito social. }\end{array}$ \\
\hline
\end{tabular}


Quadro 3: Resumo da proposta metodológica e técnica.

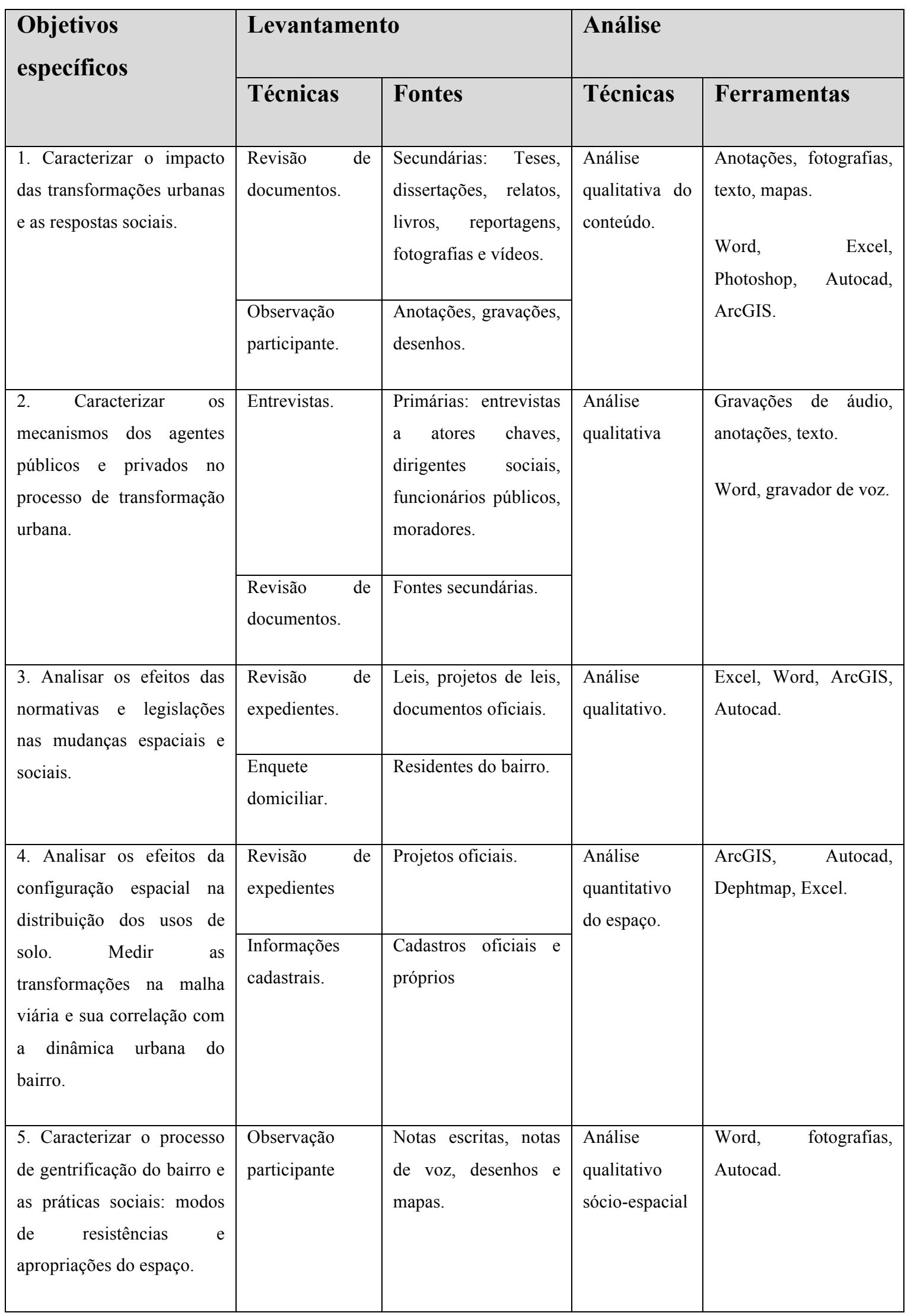




\section{ASPECTOS SOCIOECONÔMICOS}

\section{História urbana}

A seguir, relata-se a história da Vila Planalto em relação às transformações urbanas. Divide-se a história do bairro em quatro períodos: 1) Provisório necessário (COÊLHO, 2007), auge e desmantelamento dos acampamentos, desde sua origem em 1956 até a saída das empresas construtoras em 1964; 2) Abandono, estigmatização e fixação, desde 1964 com o início da ditadura e a diminuição da população, até 1988 quando se declara o tombamento e a fixação da Vila; 3) Tombamento, colonização e transformações, desde 1988, após a fixação, até 2010; e 4) Vila Planalto gourmet, o consumo do patrimônio cultural, valorização imobiliária e expulsão, desde 2010 com o início do primeiro projeto de intervenção no patrimônio cultural voltado para o turismo, até hoje, momento de borbulhante oferta imobiliária.

1) 1956 - 1964: Provisório necessário, auge e desmantelamento dos acampamentos.

A Vila Planalto tem sua origem em Agosto de 1956 com o início da construção da Residência Presidencial (Palácio Alvorada) no lugar que seria a nova capital do país. Com a lei de transferência da capital, promulgada em setembro, começa a instalação dos acampamentos com a chegada das primeiras empresas construtoras, Rabello S.A. ${ }^{8}$ e Pacheco Fernandes Dantas, localizadas nas proximidades das obras que concretizavam: o Palácio da Alvorada e o Brasília Palace Hotel, respectivamente. Depois do concurso que escolheu o Plano Piloto de Brasília (PPB) de Lucio Costa, mais construtoras se instalaram na área, principalmente pela facilidade do acesso a obras como: Palácio do Planalto, Congresso Nacional e Supremo Tribunal Federal (STF) na Praça dos Três Poderes, e blocos ministeriais, Teatro Nacional e Rodoviária na Esplanada dos Ministérios.

O maior número de acampamentos e de habitantes na Vila Planalto se registra entre os anos 1959 e 1961, com 22 acampamentos e 19.000 habitantes numa área de 310 hectares (ZARUR, 1991). Entre as empresas que ali tiveram seus acampamentos estão:

\footnotetext{
${ }^{8}$ A empresa construtora Rabello S.A. havia construído os edifícios de Niemeyer em Pampulha (Minas Gerais) quando Juscelino Kutbischek era prefeito de Belo Horizonte.
} 
ADIL, ATLAS, COSISPA, CVB, DFL, DTUI, EBE, ECISA, EMULPRESS, ESOL, ECIL, MINEIROS, NACIONAL, PACHECO FERNANDES, PEDERNEIRAS, PLANALTO, RABELO, TELEBRAS, TAMBORIL Y WSK (ZARUR, 1991). Na época foi a mais importante aglomeração em termos de habitantes, nos acampamentos moravam milhares de trabalhadores da construção civil.

Em 1958 a questão da habitação nos canteiros de obras chega a um momento crítico e começam a surgir as primeiras "cidades satélites" como Taguatinga, ou vilas operárias "livres", como a Vila Amauri e a Vila Palha (RIBEIRO, 2008). Nestas últimas, consideradas as primeiras invasões de Brasília, moravam 6.196 habitantes, localizados junto à Vila Planalto numa área que posteriormente seria alagada pelo Lago Paranoá. Os assentamentos se estendiam desde as imediações do Palácio da Alvorada, ocupando o Setor de Clubes e Embaixadas Nortes (SCEN) até a Av. das Nações ou L4.

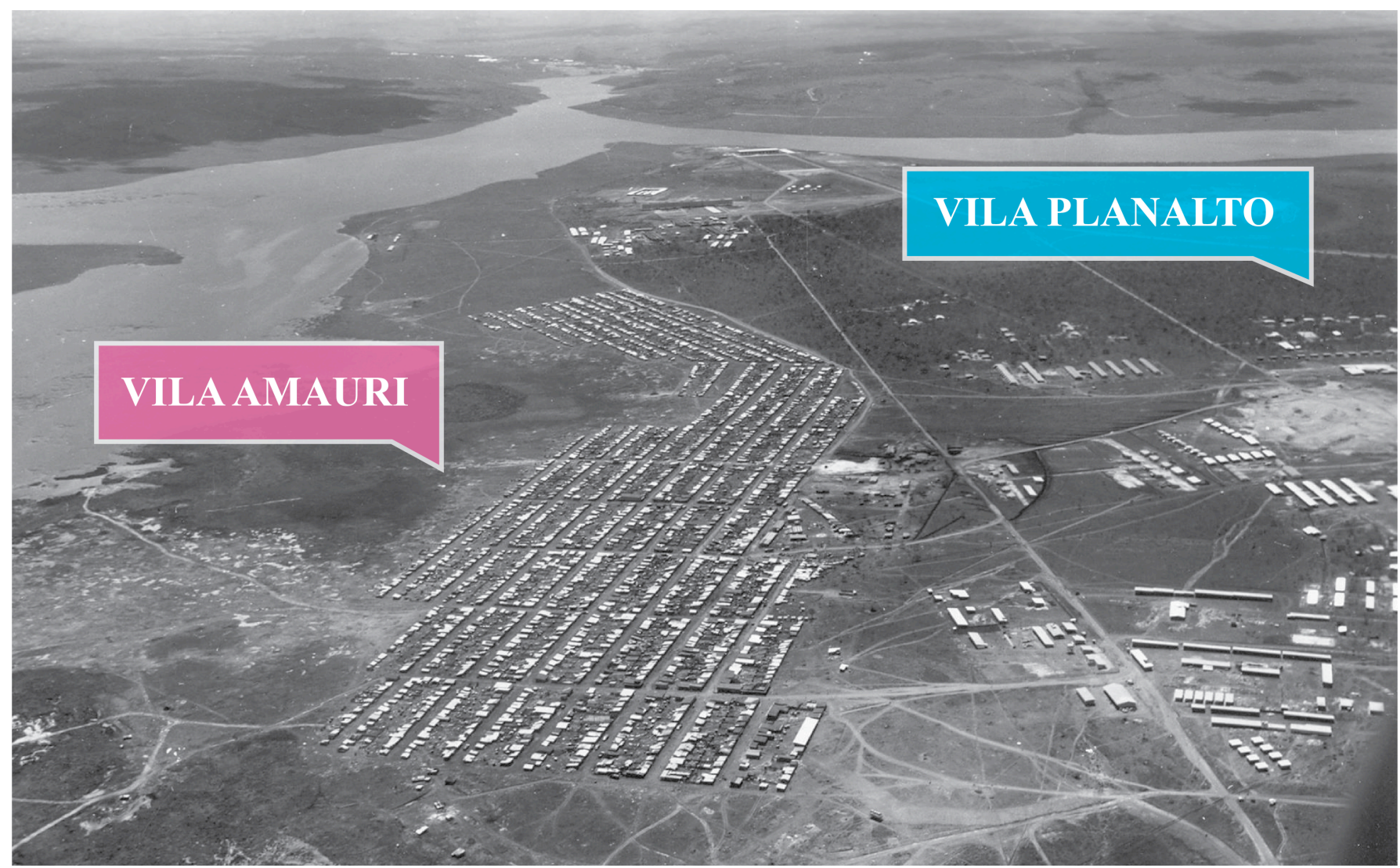

Figura 9: Fotografia da época da construção. No centro a Vila Amauri, à direita os acampamentos da Vila Planalto e no fundo o Palácio da Alvorada. Fonte: Arquivo Público do Distrito Federal, s.d. 
A organização espacial inicial da Vila se modifica constantemente ao longo do período da construção de Brasília, e novos padrões de assentamento foram criados para atender às necessidades produtivas e gerar as condições para a finalização das obras. As diferenças internas se traduziam em características concretas no território do projeto, como a segregação entre trabalhadores casados e solteiros, ou entre a mão de obra qualificada e a não qualificada, estabelecendo rígidas restrições sociais.

Os acampamentos eram unidades cercadas, hierarquizadas internamente, autônomas e independentes entre si, sobre as quais as respectivas empresas tinham domínio absoluto. Havia grades, controle de entrada e saída, subordinação dos operários ao monopólio territorial, vigilância constante e dominação da vida cotidiana. A disposição espacial das casas da Vila respondia à hierarquia das funções na obra. As localizações das residências nos acampamentos impuseram a segregação espacial ao traçado dos acampamentos. Por exemplo, o presidente da empresa tinha a melhor casa no melhor lugar, enquanto os peões permaneciam nos alojamentos coletivos e tinham as piores instalações na área mais sujeita a restrições disciplinares.

As características de padrão do assentamento planejado apresentam claramente como a estratificação interna do projeto implantado à realidade espacial e como as áreas residenciais e sistemas de serviços foram determinados para atender às necessidades internas de cada acampamento (RIBEIRO, 2008). Na Vila Planalto, a malha urbana regular com ruas ortogonais era expressão do Movimento de Arquitetura Moderna (KOHLSDORF, 2010a) e facilitava a fiscalização; as casas geminadas em fileira, ou isoladas, progrediam segundo o nível de controle do espaço.

$\mathrm{O}$ acesso aos equipamentos e serviços era diferenciado segundo a hierarquia da empresa. O espaço público era determinado pela lógica da atividade produtiva, ao ser projetado como parte de um esquema de produção planejada e totalitária, mas também pela superposição das relações de trabalho como a vida diária. Dentro das atividades recreativas destacavam-se os campeonatos de futebol, que aconteciam entre os times oficiais de cada empresa. Os clubes dos acampamentos eram frequentados pelos engenheiros e funcionários graduados e suas famílias. Os operários solteiros compartilhavam banheiros e tanques coletivos para lavar roupa, em lugares próximos aos alojamentos. 
O poder das administrações centrais incrementa as semelhanças dos acampamentos de obras com as "instituições totais" 9. A imobilização da força de trabalho ${ }^{10}$ por moradia se caracteriza por especificidades nas relações entre trabalho e capital, o domínio da produção invade outros âmbitos da vida doméstica dos trabalhadores. Os alojamentos passam a ser entendidos como uma maneira de conter um grande número de trabalhadores em um pequeno espaço. O incremento do controle imposto a trechos do acampamento expressa a polaridade entre solteiros e casados com suas respectivas restrições territoriais. Enquanto os casados desfrutavam dos privilégios de refugiar-se em suas casas, os peões de obras eram submetidos a passar noites completas trabalhando em péssimas condições laborais.

Entre os acampamentos existentes na época, o TAMBORIL, construído para funcionários de uma empresa norte-americana que foi a primeira a deixar a cidade, é o que possuía os maiores lotes e as casas em melhores condições. As casas, quando desocupadas, foram entregues a funcionários graduados e engenheiros da NOVACAP ${ }^{11}$.

A construtora RABELO, uma das mais importantes durante a construção de Brasília, tinha o maior acampamento e melhor equipado, chegando a abrigar até três mil pessoas. Nas instalações existia uma marcada diferenciação social estratificada segundo a função dos trabalhadores. A distribuição espacial das casas e o traçado da malha urbana se correlacionam diretamente como a estratificação funcional da empresa. Por exemplo, nas avenidas Belém, Brasília e JK localizavam-se as casas pertencentes a altos funcionários administrativos e engenheiros, logo substituídos por mestres de obras, chefes e encarregados. Nas ruas 1, 2, 3 e 4 e na Av. Israel Pinheiro se instalaram os funcionários e operários casados (ZARUR, 1991; COÊLHO, 2007). A figura 10 mostra um esboço com a distribuição espacial do acampamento original durante a época da construção de Brasília.

\footnotetext{
${ }^{9}$ Lugar de residência e trabalho, onde um grande número de indivíduos com situação semelhante, separados da sociedade mais ampla por um período de tempo considerável, tem uma vida fechada e formalmente controlada (RIBEIRO, 2010).

${ }^{10}$ Este conceito refere-se a uma estrutura de relações sociais que envolvem o monopólio do poder sobre o território, a produção, a moradia e demais aspectos da vida dos operários, estabelecendo um padrão de dominação que influencia as instâncias administrativas, legais, e na caracterização urbana dos locais sujeitos a este tipo de controle (ZARUR, 1991).

${ }^{11}$ Companhia Urbanizadora da Nova Capital.
} 
Como se observa na figura 10, no espaço aberto, onde atualmente está a Praça Nelson Corso, localizavam-se a igreja, o cinema, a drogaria, a enfermaria e o consultório médico e dental, um posto telefônico e de gasolina, todos demolidos, apenas sobreviveu o armazém (atual mercado Armazém do Geraldo). Os clubes funcionaram até 1964, quando foram demolidos. Perto desse lugar estavam os alojamentos dos solteiros, separados por uma grade; também separados por muros de madeira estavam os alojamentos de 120 serventes em galpões, conhecido como a "Fazendinha da Rabello".

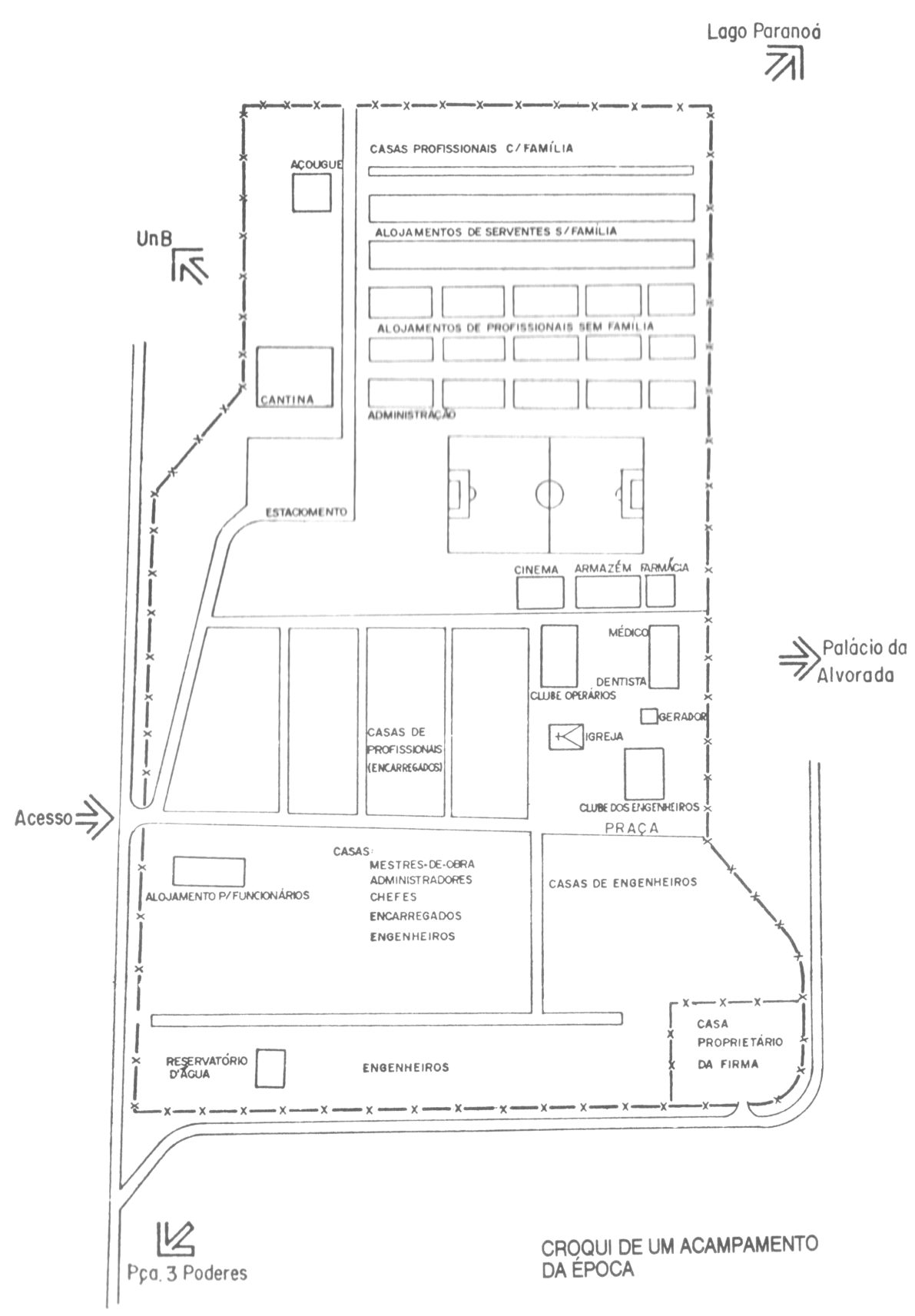

Figura 10: Croqui esquemático do acampamento RABELO na Vila Planalto.

Fonte: (RIBEIRO, 2010, p.39). 
Ribeiro (2010) reconhece uma segmentação dual do acampamento, definido por dois lados. De um lado, os trabalhadores sem família (serventes e profissionais), com alojamentos coletivos de condições precárias ocupando um espaço menor; e outro lado, onde residem os controladores da produção e suas famílias em casas individuais dispostas num espaço maior.

[...], o acampamento, sua construção, configuração e utilização, é universo privilegiado para perceber a estruturação do espaço de acordo com as diferenças de classe e, concomitantemente, as diferenças internas a um determinado ramo da produção. Dos miseráveis, sujos e apertados alojamentos coletivos dos serventes até a luxuosa e espaçosa casa do proprietário da companhia, a divisão deste espaço é claramente orientada pela lógica da esfera da produção, [...]. (RIBEIRO, 2010, p.42-43).

A manutenção da ordem era garantida por uma força policial das empresas e por um grupo subordinado à NOVACAP denominado GEB (Guarda Especial de Brasília). A falsa ideia de liberdade de escolha para dispor da sua força de trabalho no mercado ocultava as condições dos trabalhadores nos alojamentos coletivos. Os trabalhadores estavam sujeitos ao sistema de dominação por meio da entrega de casas (ZARUR, 1991).

No dia 8 de Fevereiro de 1959 ocorreu um episódio sangrento na história de Brasília. No acampamento da empresa Pacheco Fernandes Dantas, que construía o Palácio do Planalto, a GEB reprimiu violentamente uma revolta dos operários que reclamavam das péssimas condições de vida. Os fatos nunca foram esclarecidos. A história oficial reconhece apenas um morto e quatro feridos, porém os relatos de trabalhadores contabilizam centenas de colegas assassinados, no que foi chamado de "Massacre da Pacheco Fernandes". O episódio afetou os trabalhadores e muitos fugiram assustados. Na figura 11 se mostra uma fotografia do memorial instalado no local pelos próprios moradores. 


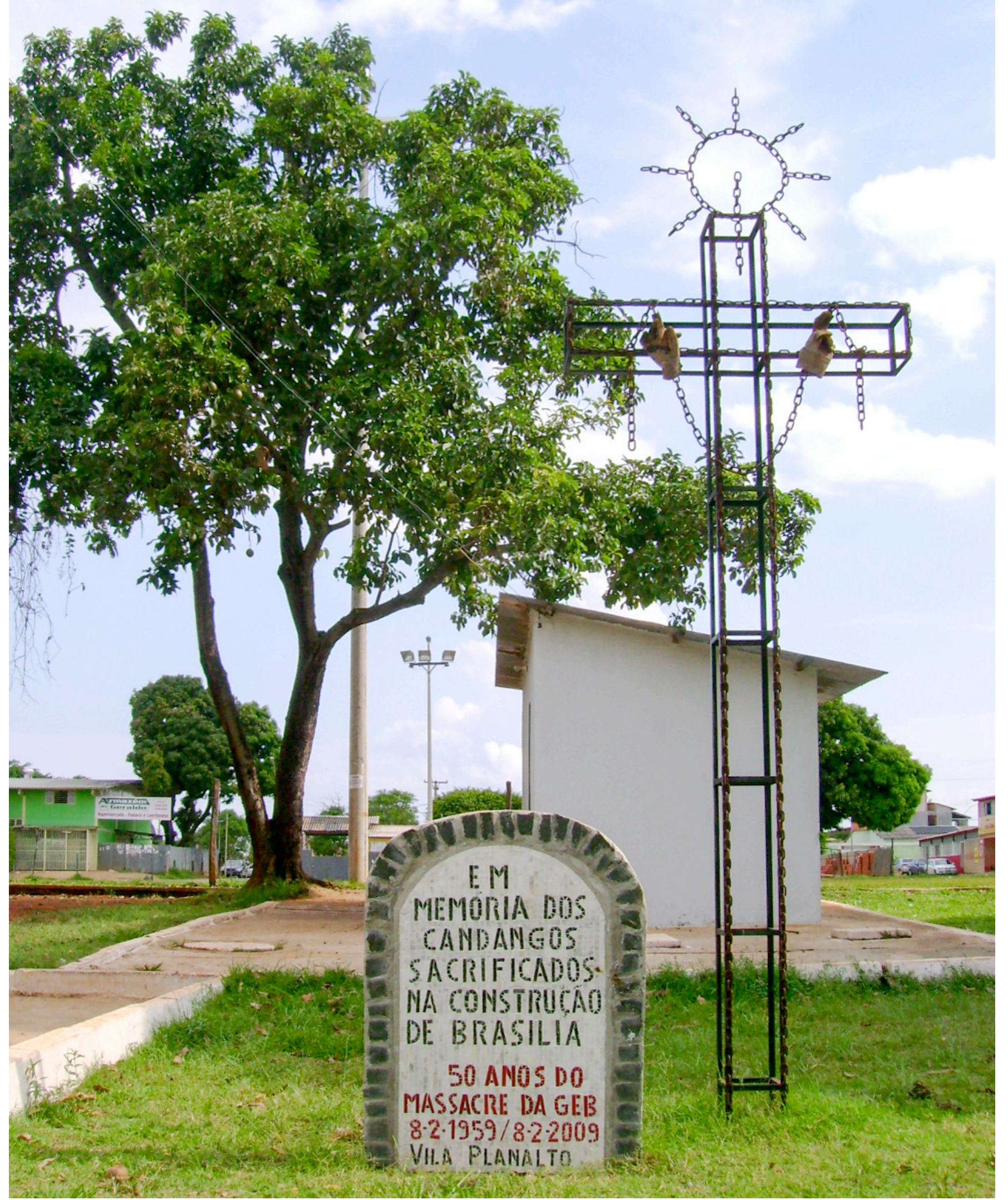

Figura 11: Memorial do Massacre da Pacheco Fernandes na Praça Zé Ramalho.

Fonte: Arquivo pessoal, (21.09.2009). 
Em 21 de abril de 1960, com a inauguração da capital, começa uma gradual desmobilização da forma de produção característica dos grandes projetos. Nos acampamentos da Vila, muitos dos serviços e das instalações das empresas encarregadas pelos acampamentos foram eliminados começando um processo de diminuição da área ocupada e da população. Dos 19.000 habitantes em 1959 na Vila Planalto, em 1964 só se contabilizaram 6.500. O interesse inicial pela oferta de emprego gerou uma atração permanente que foi se dissipando após a inauguração. A propriedade dos lotes e das construções passou das construtoras para a NOVACAP, e daí para a TERRACAP, o que provocou a redução dos benefícios aos moradores e da fiscalização do local. Houve mudanças e diversas situações irregulares na ocupação do espaço.

Em 1960 as águas do Lago Paranoá atingiram parte importante de alguns acampamentos e principalmente das invasões próximas, como a Vila Amauri e a Vila da Palha, que foram completamente inundadas. Alguns moradores conseguiram se refugiar na Vila Planalto, onde o controle havia diminuído, mas a maioria foi transferida para Sobradinho e Gama, a 22 km e 40 km do Plano Piloto, respectivamente.

Algumas casas foram transferidas para engenheiros da NOVACAP. As casas de madeiras foram ocupadas como residências funcionais, as maiores e melhor equipadas eram destinadas a altos funcionários do governo do Distrito Federal. Nos alojamentos coletivos permaneciam os operários mais pobres, agora acompanhados de suas famílias, produzindo-se condições de confinamento.

A acumulação de migrantes fora do controle do Estado provocou a ocupação e invasão de áreas improvisadas, e a consequência foi a criação antecipada das cidades satélites e a luta pela fixação de acampamentos como a Vila Planalto. Desde a inauguração de Brasília até o golpe militar de 1964, a política urbana e territorial do Distrito Federal se concentrou em remover a maioria das favelas e "invasões" que surgiram durante a construção (PAVIANI, 1991).

2) 1964 - 1988: Abandono, estigmatização e fixação.

Com o fim da construção dos edifícios principais para o funcionamento da nova capital gradualmente se desativaram as obras e os acampamentos. Surgiu uma nova legalidade institucional que substitui a "ambiguidade jurídica" em que se encontrava a cidade e em que a NOVACAP possuía diversos poderes para administrar as empreiteiras (ZARUR, 1991). Isso provocou a diminuição da vigilância e do controle 
imposto durante a construção. Nos acampamentos, os trabalhadores menos qualificados tiveram menos poder de negociar sua permanência na área urbana dos antigos acampamentos, comparados com os altos funcionários das empresas públicas e privadas.

Paviani (1991) define que uma das premissas básicas da política urbana e territorial do Distrito Federal durante o regime militar (1964-1985) continuou sendo a de controlar e expulsar a população sem habitação ou em situação informal. $\mathrm{O}$ autor menciona que a única exceção ocorreu durante o governo de José Ornellas (militar) (1980-1985) com a criação do Grupo Executivo para Assentamento de Favelas e Invasões (GEPAFI).

Depois do golpe militar a repressão aos movimentos contra erradicações passou a ser intensa, repetindo a violência exercida pela GEB (ZARUR, 1991). O medo pela erradicação estendeu-se a todos os conjuntos de casas de madeira, ainda que estivessem em boas condições. A precariedade no interior da Vila aumentou, mas a estratificação interna persistiu ao longo do período militar.

As condições de intimidação depois do Golpe de Estado de 1964 aumentaram as tensões entre os diferentes segmentos sociais na Vila. O reflexo das distinções sociais percebe-se na reorganização espacial dos acampamentos entre si, como também nas condições materiais e de conservação das casas. As melhores casas, ocupadas por famílias de maior renda, tornaram-se mais visíveis, oferecendo uma imagem pitoresca e arborizada para o exterior. As casas mais populares ficavam ocultas e os alojamentos coletivos foram sistematicamente destruídos, apesar de terem alojado os construtores da cidade.

Embora a concepção dos acampamentos diferisse daquela subjacente às favelas, a má conservação de seus prédios levou-os a compartilhar o estigma associado às construções provisórias. O baixo status ao qual a Vila Planalto esteve relegada até ser regularizada tornou-a quase tão malvista quanto os demais assentamentos irregulares. Os antigos alojamentos de solteiros, construções de má qualidade já na época da edificação, agravaram esse traço à medida que passaram a abrigar famílias de operários humildes nos seus cubículos. (PAVIANI, 1996, p.88)

A diferenciação interna da Vila, existente desde o início do assentamento para privilegiar os altos funcionários, adaptou-se às novas condições impostas pela ausência 
do monopólio de vivenda exercido pelas construtoras. $\mathrm{O}$ enfraquecimento da indústria da construção civil e do controle do espaço refletiu-se na distribuição hierárquica das casas nos acampamentos da Vila, mas também na qualidade e no tamanho das edificações, à medida que elas eram destinadas a operários ou a pessoas com altos cargos. A introdução do funcionalismo e a racionalização nesse espaço já hierarquizado abriram novas possibilidades de reivindicar a moradia definitiva, recebida gradualmente pelos moradores originais. Os moradores da Vila adaptaram-se a momentos políticos distintos, resistindo a erradicações e depois na luta por serviços básicos.

A permanência da Vila Planalto deve-se em parte à camuflagem causada pela densa vegetação ao redor do perímetro, ocultando as condições internas (ZARUR, 1996; KOHLSDORF, 2010a). As melhores casas se apresentavam visualmente aos visitantes, ao passo que as edificações mais precárias eram mantidas ocultas da visibilidade, para não evidenciar a pobreza de seu interior. A fachada da Vila não era correspondente com a verdadeira situação. A diversidade interna, tanto econômica, edilícia e social, foi essencial para sua preservação. Os elementos "negativos" dos acampamentos, como a precariedade dos alojamentos coletivos, contrapõem-se aos atributos "favoráveis", como as residências funcionais e o apoio político à população (ZARUR, 1991).

Outro motivo para sua permanência foi o fato de que as melhores casas eram habitadas por altos funcionários do governo da União e do Distrito Federal, fator que transformou a visão da continuidade da Vila e de invasões próximas ao centro como algo positivo para empresários da construção civil. Por uma parte, a localização privilegiada da Vila entre os principais edifícios públicos criou reações violentas contra a sua continuidade, mas por outra, gerou simpatia em setores influentes da administração.

Alguns funcionários da Rabello S.A. receberam lotes em Taguatinga, Gama e Sobradinho, e a NOVACAP cedeu as casas para serem levadas aos novos lotes. Apesar disso, a pressão por obter uma vivenda para as famílias sempre esteve presente. Em 1972, como a criação da TERRACAP, isso não foi mais possível. Os fiscalizadores da área residiam na mesma Vila, criando laços de amizade que favoreceram a permanência de alguns habitantes mais pobres, e apesar de que sempre estiveram proibidas as reformas e ampliações das casas, estas ocorreram ainda assim.

Desde 1964 até 1988, muitas casas foram demolidas, quando não eram objeto de interesse de pessoas influentes, e diversas famílias foram despejadas. Os fechamentos 
(grades e muros) que dividiam os acampamentos foram retirados, e erradicaram-se acampamentos completos ou partes deles, ocorrendo uma drástica diminuição da área total e de sua população. Contudo, algumas famílias resistiram e lograram permanecer no local. Zarur (1991) explica como neste período existiu uma gradual deterioração e adaptabilidade das edificações da Vila, principalmente na área central de alta densidade construtiva e populacional e pior situação socioeconômica. A autora propõe quatro causas possíveis para o deterioro físico: 1) progressivo encolhimento da Vila, 2) crescimento demográfico, 3) proibição de construir novas habitações, e 4) empobrecimento progressivo da população.

Com o fim da ditadura militar, o presidente José Sarney designa o novo governador, José Aparecido. Em matéria de habitação, o mandato de Aparecido se caracterizou pelas erradicações de "invasões" e pela fiscalização mais rígida e direta da TERRACAP nos barracos existentes em Brasília. Com a saída dos militares não terminaram as ações repressivas e a política de expulsão da população do Plano Piloto; essa política era implementada, agora, pela ausência de oferta de lotes e pela proibição de ampliação das cidades satélites (PAVIANI, 1991). A Vila Planalto se transformou em alternativa para quem não conseguia comprar ou alugar um imóvel, surgindo um comércio informal da cessão de direitos de aquisição de imóveis. No processo de especulação imobiliária dessa época, moradores mais humildes recebiam em dinheiro pela cessão de direitos, sendo enganados em diversas ocasiões (ZARUR, 1991).

No local houve um processo gradual de mobilização dos habitantes frente a problemas pontuais. O conceito de pioneiro é fundamental para entender tanto a ideologia da época de construção quanto a identidade contemporânea de candangos e brasilienses. Os habitantes da Vila Planalto souberam utilizar para seu benefício essa identidade, que traspassou os diferentes estratos sociais e as diferentes fases do assentamento (ZARUR, 1991).

Os antigos operários começaram a fazer alianças com os novos moradores, para driblar o controle implacável da TERRACAP, que objetivava evitar o crescimento do numero de casa e, principalmente, o aumento da população pobre. A distinção entre "Fazendinha pobre" e "Fazendinha rica", "Tamboril de baixo" e "Tamboril de cima" evidencia a heterogeneidade social da Vila Planalto. Heterogeneidade que diversificou as estratégias de luta por moradia e pela continuidade dos acampamentos. (PAVIANI, 1996, p.89) 
No final da década de 1980, com os preparativos para uma nova Constituição, as organizações da sociedade civil se fortalecem, provocando a intensificação da mobilização popular pela permanência da Vila Planalto. Formaram-se associações voluntárias de acordo com interesses comuns, como associações de mães, centro social etc. Uma organização relevante que permanece ativa até hoje é a Associação de Moradores da Vila Planalto (AMVP), que surgiu em 1982. Os moradores passaram a reivindicar, como atores da história da cidade, não somente a preservação da Vila em si, também o direito de permanecer em suas casas. A AMPV, especificamente, reivindicava a entrega dos lotes como forma de fixação, levantando como consigna a frase: "não queremos tombamento, queremos loteamento".

Nos anos 1980, a gestão de Aloísio Magalhães na Secretaria do Patrimônio Histórico e Artístico Nacional e Fundação Nacional Pró-Memória (SPHAN/Prómemória) propõe nova política de preservação de Brasília, fundamentada em uma visão de bem cultural que procura a manutenção do caráter dinâmico e vivo do patrimônio. A partir de reuniões entre o Ministério da Cultura (MinC), o Governo do Distrito Federal (GDF) e a Universidade de Brasília (UnB), em 1981, é criado o GT-Brasília (Grupo de Trabalho).

A fixação da Vila Planalto resultou de um trabalho conjunto entre órgãos locais, federais e a população organizada, permitindo garantir a preservação da memória do núcleo urbano e a permanência de duas mil famílias em uma área bem localizada (RIBEIRO, 2005). Esse processo, liderado pelo GT-Brasília, pode ser considerado como uma estratégia de reabilitação urbana, devido ao enfoque dado à proteção e fixação da Vila, onde a população teve um papel relevante na solução dos problemas de moradia. Assim, a Vila Planalto teve uma importância singular na implementação de políticas culturais participativas. O GT-Brasília começou a trabalhar em 1984 com uma equipe multidisciplinar, composta de técnicos, professores e estagiários, instalados num escritório na própria Vila.

Em 1985, Lucio Costa visita Brasília e revisa a condição do Plano Piloto, passados 25 anos da inauguração. No documento "Brasília Revisitada", Costa faz observações sobre a situação da Vila Planalto e propõe para o local a implantação das "Superquadras Planalto". Preocupado com a descaracterização do percurso entre a cidade e o Palácio da Alvorada que poderia acontecer com a expansão do loteamento, o 
urbanista entrega diretrizes para a fixação do núcleo residencial antigo e a construção de novas moradias seguindo o padrão das superquadras.

Para Costa (1985), a fixação da Vila estaria condicionada à liberação de uma faixa de $250 \mathrm{~m}$ de largura por $2 \mathrm{~km}$ de comprimento paralela à EHTN (Estada de Hotéis e Turismo Norte), onde seriam implantadas sete Superquadras de residências multifamiliares em blocos de quatro pavimentos sobre pilotis. Apesar de considerar inevitável a fixação, o projeto procura invisibilizar a presença das habitações unifamiliares por ferir a monumentalidade. São quatro as diretrizes propostas pelo urbanista: 1) manutenção do loteamento existente, preservação das construções de madeira e arborização dos espaços vazios; 2) não permitir o surgimento de pequenas ruas, ao contrário, devem ser construídas alamedas sinuosas de parque; 3) casas de um pavimento, podendo ser elevadas em até $2,20 \mathrm{~m}$, e segundo pavimento até $1 / 4$ da projeção da casa; 4) garantir apenas o direito de uso do solo e não alienar os lotes.

Em face das dificuldades, como a opinião de Lucio Costa e as pressões imobiliárias e políticas para erradicar a Vila Planalto, Zarur (1991) e Ribeiro (2005) destacam a importância da atuação do GT-Brasília para conseguir a fixação. As autoras ressaltam o trabalho de conscientização da população sobre a questão da identidade e do patrimônio cultural, conseguindo dissuadir as autoridades da ideia de erradicação. A estratégia adotada pelo grupo privilegiou uma troca de saberes entre técnicos e moradores, o enfoque antropológico adotado no trabalho permitiu reconhecer a história da Vila e os relatos de seus habitantes, evidenciando o referencial simbólico dos espaços públicos e privados. A figura 12 apresenta um cartaz com desenhos elaborados pela equipe do GT como informativo para os moradores.

O resultado dos trabalhos foi o "Projeto de fixação da Vila Planalto", desenvolvido com a população, que reconhecia a deterioração das casas e a precariedade da infraestrutura e destacava os bens simbólicos e a resistência dos moradores a erradicações. O projeto tinha como objetivo a preservação do conjunto, resguardando a identidade local e as relações de vizinhança. 


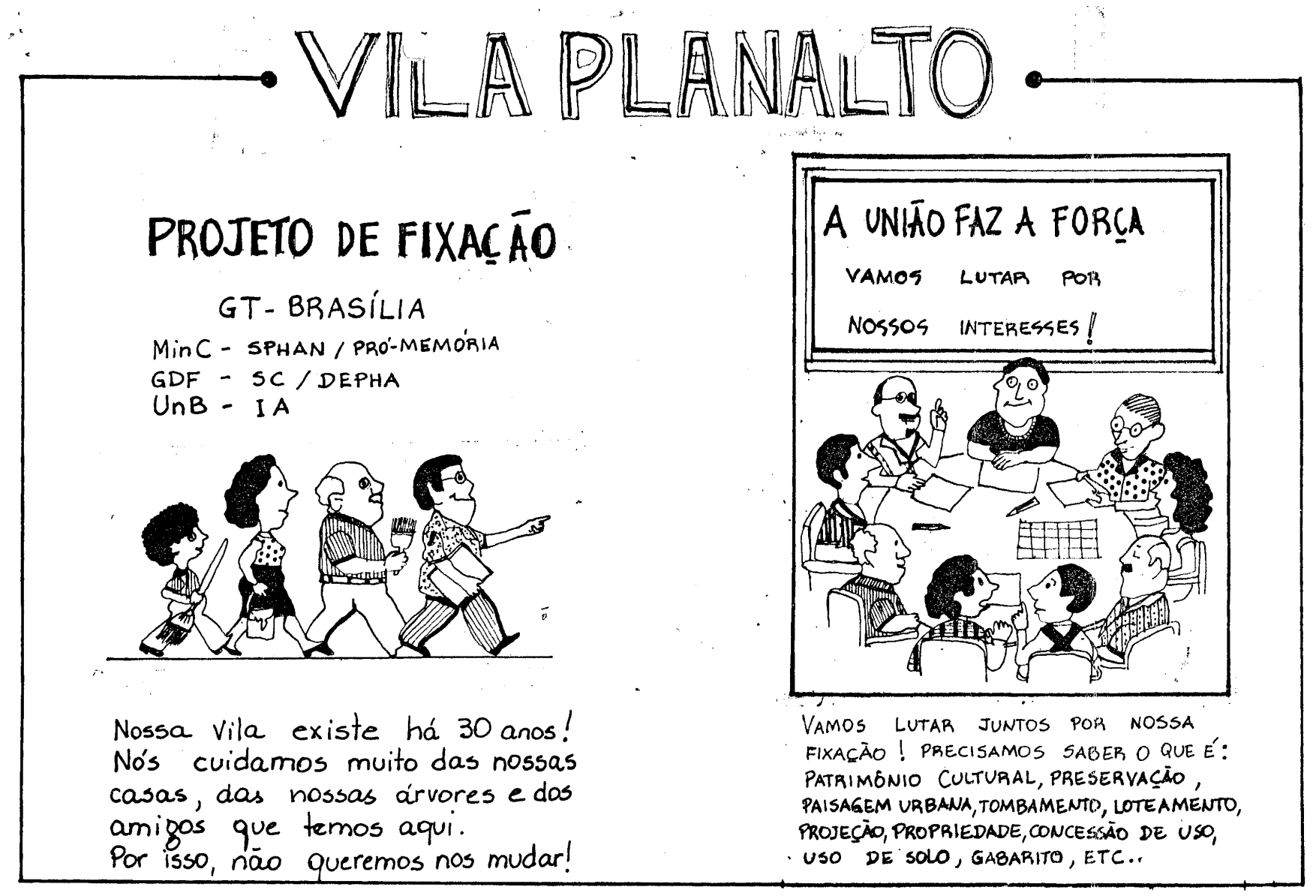

Figura 12: Cartaz de conscientização do projeto de fixação elaborado pelo GT-Brasília.

Fonte: Arquivo Superintendência IPHAN-DF, s.d.

Outros relatos históricos sobre o processo de fixação da Vila Planalto ressaltam a atuação de um grupo de mulheres conhecido como "Grupo das dez" que, orientadas por assistentes sociais do Centro de Bem-Estar do Menor (CEBEM), organizaram a comunidade. Documentos mencionam um acontecimento relevante no processo. No dia 17 de julho de 1986, Leiliane Rebouças, de 10 anos de idade, consegue entregar uma carta para o Presidente Sarney, pedindo a fixação da Vila. Sarney teria encaminhado para o governador Aparecido, que, em 28 de agosto, recebeu o Grupo das dez com a menina e anunciou os planos do tombamento da cidade.

Depois de longo período de clandestinidade e como resultado concreto da ação do GT-Brasília, dos moradores organizados e de alguns governantes, no dia 21 de abril de 1988 a Vila Planalto foi tombada e fixada pelo Departamento do Patrimônio Histórico e Artístico do DF (DePHA) e pelo IPHAN como patrimônio histórico do Distrito Federal, e isso aconteceu um ano depois do reconhecimento de Brasília como patrimônio da humanidade pela UNESCO ${ }^{12}$.

\footnotetext{
${ }^{12}$ Organização das Nações Unidas para a Educação, Ciência e Cultua.
} 


\section{3) 1988 - 2010: Tombamento, colonização e transformações.}

O Decreto $\mathrm{N}^{\circ} 11.079$ dispôs sobre o tombamento da Vila Planalto, classificando o conjunto como patrimônio histórico. $\mathrm{O}$ documento destaca o caráter simbólico e o ambiente bucólico dos acampamentos. Ele considera como características a serem preservadas: 1) a mimetização com a paisagem, 2) a desocupação total da área de tutela considerada non aedificandi, 3) o traçado urbano original, 4) a identidade, 5) a linguagem arquitetônica, e 6) os espaços de valor simbólico. O decreto tipifica como crime a destruição, mutilação ou alterações das características mencionadas. Por sua parte, o Decreto $\mathrm{N}^{\circ} 11.080$ especifica os critérios de fixação da Vila Planalto, com o objetivo de assegurar sua preservação física e social. São três os critérios a serem cumpridos pelos moradores para a fixação: 1) habitar há pelo menos 5 anos no local, 2) estar cadastrado no levantamento socioeconômico de 1986/87 realizado pela Secretaria de Habitação de Interesse Social (SHIS), e 3) não ser proprietário, cessionário ou proeminente comprador de outra residência no DF. O decreto também determina a criação do Grupo Executivo para o Assentamento da Vila Planalto (GEAP) e termina com o trabalho do GT-Brasília na gestão do bairro.

\footnotetext{
A interrupção da gestão participativa naquele bairro, somada à crescente elitização do Plano Piloto e à força da especulação imobiliária, além da concepção restrita de planejamento, contribuíram para o cenário de descaracterização dos espaços urbanos da Vila e a não permanência de grande parte dos moradores originais. (RIBEIRO, 2005, p. 120)
}

Ribeiro (2005) comenta que os decretos não foram suficientes para garantir a preservação das características essenciais da Vila Planalto. A luta pela fixação mobilizou a população pelo direito à moradia, o que derivou numa luta pela preservação como estratégia política. Depois da fixação, sem um objetivo comum, reaparecem os conflitos entre os grupos sociais. Os interesses imobiliários e da classe média se manifestariam com mais força. A falta de condições econômica e cultural da população mais pobre contribuiu para o desfavorecimento de muitos pioneiros, que não resistiram à elitização do Plano Piloto e transferiram seus direitos por meio de contratos de compra e venda.

O tombamento transformou a Vila Planalto em um lugar desejável para morar por dois motivos: primeiro, pela centralidade e proximidade com o eixo monumental; e segundo, pelo reconhecimento de suas características físicas e sociais como um valor histórico, eliminando o estigma de "invasão". 
A fixação foi regulamentada em março de 1990 pelo Decreto $\mathrm{N}^{\mathrm{o}} 12.247$ - a ferramenta para que diversas famílias recebam lotes. Para isso estabeleceu seis regras: 1) morador cadastrado na SHIS (1986-87); 2) residência mínima de cinco anos comprovada pela TERRACAP, CEB ou CAESB; 3) a GEAP aprova os documentos; 4) concessão de uso de 25 anos prorrogável; 5) taxa de ocupação com desconto para menores rendas; e 6) cumprimento das normas de gabarito e uso do solo (NGB).

O poder entregado à GEAP no processo de radicação dos moradores possibilitou o favorecimento a grupos de pessoas, que sem ser pioneiros da construção de Brasília chegaram ao final dos anos 1980 e inícios de 1990 por meio da compra dos direitos, subdivisões de lotes, invadindo áreas públicas ou lotes vazios. A composição dos integrantes da GEAP foi mudada em varias ocasiões, mas começou composta por: 5 representantes do GDF, 3 do Conselho Comunitário da Vila Planalto, 1 da TERRACAP, 1 do DePHA, 1 da SHIS, e 1 da CAESB. Assim, os mesmos órgãos que entregavam os comprovantes de tempo de residência eram os responsáveis pela decisão final de entrega das concessões de direito de uso.

A maioria dos novos residentes do bairro pertencia à classe média. Esse grupo de pessoas, que poderíamos classificar como colonizadores, chega em um momento de deterioração e incerteza jurídica. São famílias de funcionários públicos, acadêmicos, artistas ou profissionais liberais que se arriscaram para morar em lugar diferente, considerando, por exemplo, que a Vila ainda não tinha esgoto e a principal infraestrutura tinha sido demolida. Zarur (1991) descreve que quanto mais cedo chegavam os funcionários públicos a morar, maior era sua identificação como pioneiro.

A entrega das concessões concretizou-se em 29 de maio de 1992, com a promulgação da Lei $\mathrm{N}^{0}$ 271, que autorizou o Poder Executivo a fixar os moradores, e incorporou 248 famílias de filhos de pioneiros que também reivindicavam lotes não cadastrados no levantamento de 1986/87 da SHIS. As figuras 13 e 14 apresentam as diferenças entre a proposta de fixação e o plano aprovado. Com os anos, outras leis e decretos permitiram a obtenção de concessões de lotes por mais famílias, inclusive flexibilizando as regras para sua obtenção. Desde a fixação da Vila em 1988 até o ano 2008 foram elaborados 23 projetos de lei e promulgados 38 leis ou decretos relacionados diretamente com o bairro e seus moradores. Isso nos faz inferir que o processo de fixação foi utilizado como moeda eleitoral por parte dos políticos em busca de votos, estabelecendo uma relação clientelista entre legisladores e moradores. 


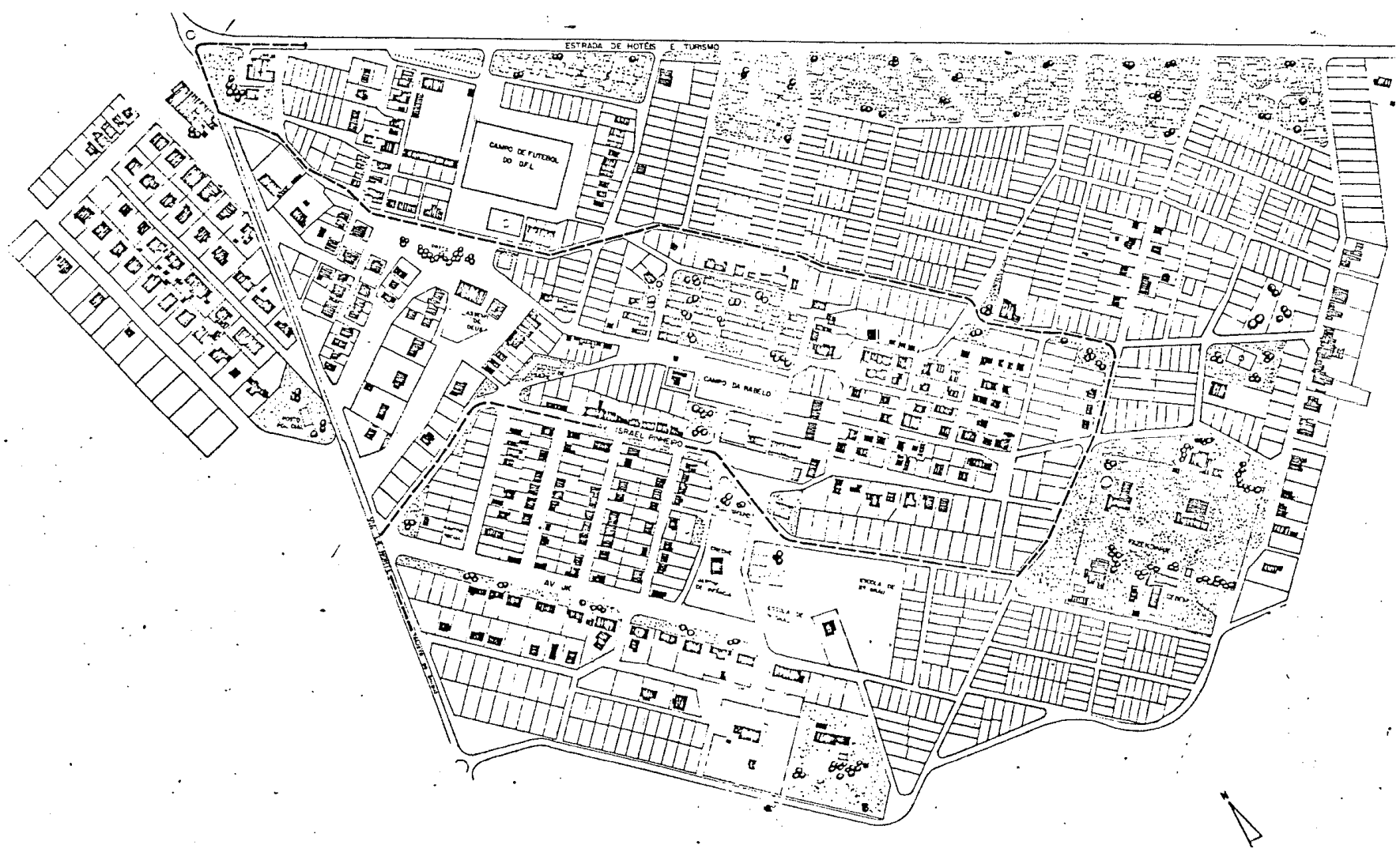

Figura 13: Estudo preliminar de fixação da Vila Planalto elaborado pelo GT-Brasília.

Fonte: Arquivo Superintendência IPHAN-DF, 1987.

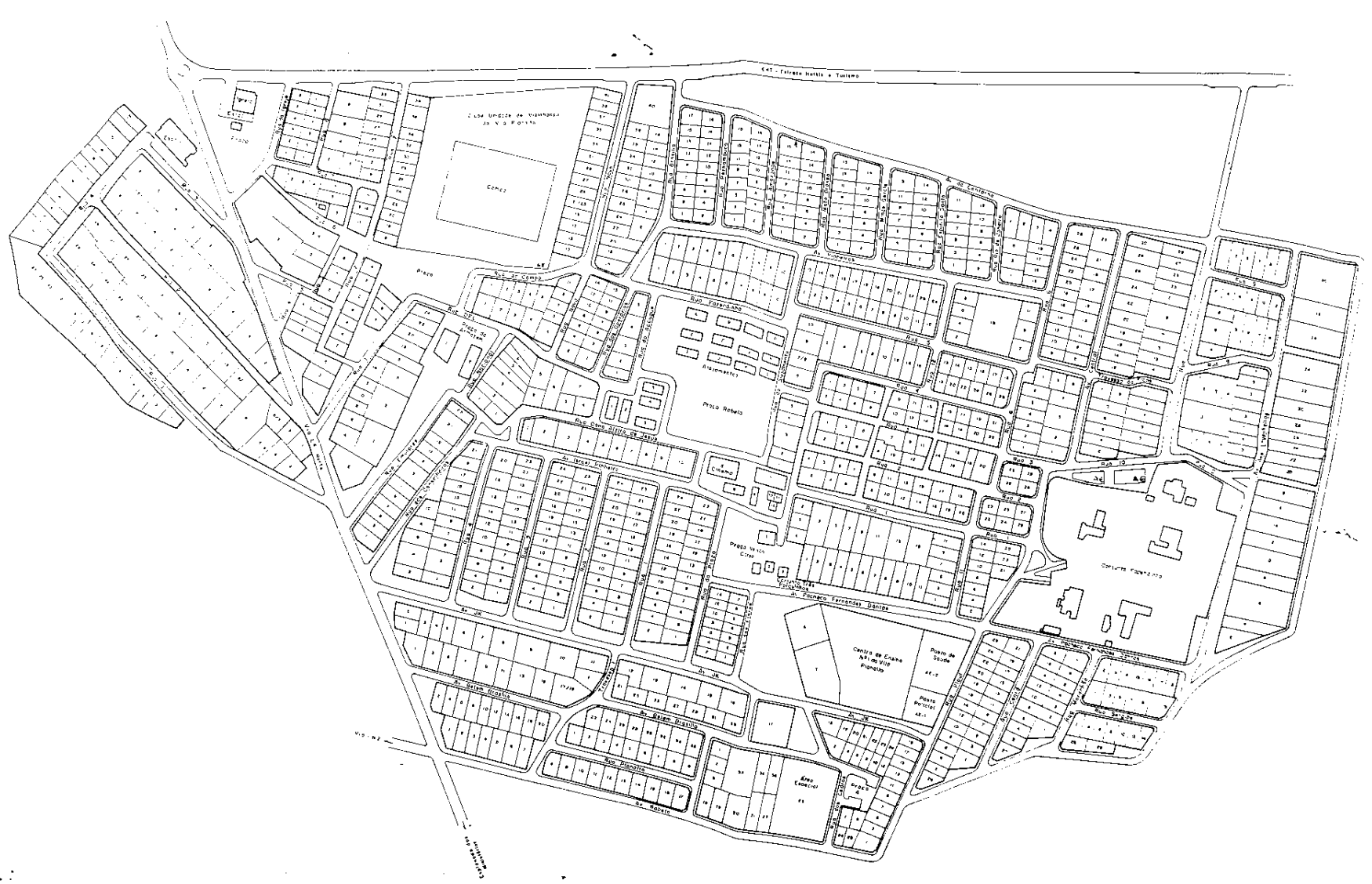

Figura 14: Plano de loteamento aprovado (URB 90/90) da Vila Planalto elaborado pela CODEPLAN.

Fonte: Arquivo Superintendência IPHAN-DF, 1994. 
Quando o governo assume a fiscalização da Vila Planalto, o controle diminui, deixando de existir os aspectos disciplinares sobre o espaço e a vida que existiam com as construtoras. A omissão dos órgãos públicos com as modificações ou novas construções da classe média não foi a mesma com as moradias mais pobres e habitações em mau estado de conservação, que foram sistematicamente demolidas, como os antigos alojamentos coletivos, onde moravam numerosas famílias.

O tombamento não garantiu a preservação das características originais, nem a permanência de sua população. Os atos governamentais não foram suficientes para a preservação do bairro histórico, ao contrário, apesar de existir critérios de ocupação definidos em 1990, continuamente ocorrem transformações espaciais e sociais, em razão das pressões imobiliárias e políticas impulsionadas pela proximidade com o Plano Piloto. A falta de vinculação entre o tombamento e o controle sobre o espaço provocou a perda das características responsáveis pela própria declaração como patrimônio. Desde o tombamento até hoje existe uma lacuna na fiscalização para o cumprimento das normas, caracterizando o período como de laissez-faire, onde o Estado simplesmente se omite e deixa fazer.

Durante a década de 1990 começa um processo intenso de transformações físicas e sociais que descaracterizam fortemente o local. Por um lado, se registra uma "colonização" ou chegada de um grupo limitado de funcionários públicos, acadêmicos e artistas, que compraram informalmente os lotes a pioneiros ou invadem terrenos. Por outro, trabalhadores de setores mais populares chegam à vila para morar com familiares ou apropriando-se de áreas não ocupadas.

Sandra Zarur (1996) explica que a diversidade social foi fundamental para obter a permanência porque permitiu ampliar o grau de influência sobre os atores políticos e eliminar o estigma de favela. A autora percebe, nas partes remanescentes dos acampamentos, uma distribuição espacial concêntrica dos níveis de renda. No acampamento Tamboril, na rua da EBE e na rua dos Engenheiros, localizadas nas bordas do bairro, estavam as maiores e melhores casas. Na parte intermediária estavam as casas geminadas de meio porte com ocupantes de renda média, e no centro, alojamentos coletivos e habitações mais pobres.

A descaracterização foi advertida por acadêmicos, órgãos de proteção do patrimônio e por moradores. Ainda assim, em 2001, legisladores apresentaram projetos para "regularizar" a situação, em uma tentativa de alterar as normas de ocupação e 
aumentar a altura do gabarito. No mesmo ano, uma missão da UNESCO em Brasília visitou a Vila Planalto e constatou a necessidade de um controle rígido das atividades de construção e das ocupações irregulares em área non aedificandi. Em 2002, aumentam as ocupações na área de tutela, formando o que é conhecido como Setor de Chácaras.

Um exemplo da falta de preservação do patrimônio histórico foi a destruição da Igreja Nossa Senha de Rosário da Pompéia, incendiada em fevereiro de 2000 (COÊLHO, 2008) pela suposta ação de criminosos. A igreja já tinha sofrido um ataque incendiário anteriormente controlado por bombeiros. $\mathrm{O}$ caso gerou polêmica e alguns textos culpam ao próprio padre, que antes havia solicitado o destombamento para poder demolir a igreja, em razão das precárias condições de conservação. A igreja foi reconstruída sete anos depois simulando a imagem da anterior.

Na década de 2000, ao mesmo tempo em que jornais publicavam notícias sobre o abandono e as construções irregulares da Vila Planalto, a TERRACAP solicitava a reintegração de posse de alguns lotes ocupados por moradores. Entre 2000 e 2008 se contabilizam 11 processos judiciais desde tipo, e na maioria dos casos a justiça favoreceu as famílias, ratificando o direito à ocupação do imóvel. Em 2006 o Tribunal de Justiça do Distrito Federal e Territórios (TJDFT) julgou inconstitucional uma lei de 1996 que permitia a transferência dos lotes aos moradores.

A mais importante transformação da malha urbana foi a duplicação da via L4, que passava pelo interior da Vila Planalto entre os acampamento Tamboril e DFL. No ano 2005, durante o governo de Joaquim Roriz (PMDB/PRTB), e como continuação das mudanças geradas pela construção da Ponte JK, foram entregue as obras que mudavam a configuração da via, que agora passa por fora da Vila e se conecta através de balões e retornos como se observa na figura 15 .

Em 2008, o governador José Arruda (PFL/DEM) promulgou um decreto criando um novo Grupo de Trabalho (GT) com o objetivo de elaborar um plano de ação na Vila Planalto. O GT é composto por três integrantes da SEDUMA-DF ${ }^{13}$, e por representantes da Secretária de Governo do DF, da Secretária de Cultura do DF, da AGEFIS, da Administração Regional de Brasília (RA-I), da TERRACAP, da CEB e da

\footnotetext{
${ }^{13}$ Secretária de Desenvolvimento Urbano e Meio Ambiente do Distrito Federal.
} 
BRASILIATUR $^{14}$. O plano resultaria em uma estratégia orientada ao turismo principalmente como polo gastronômico.

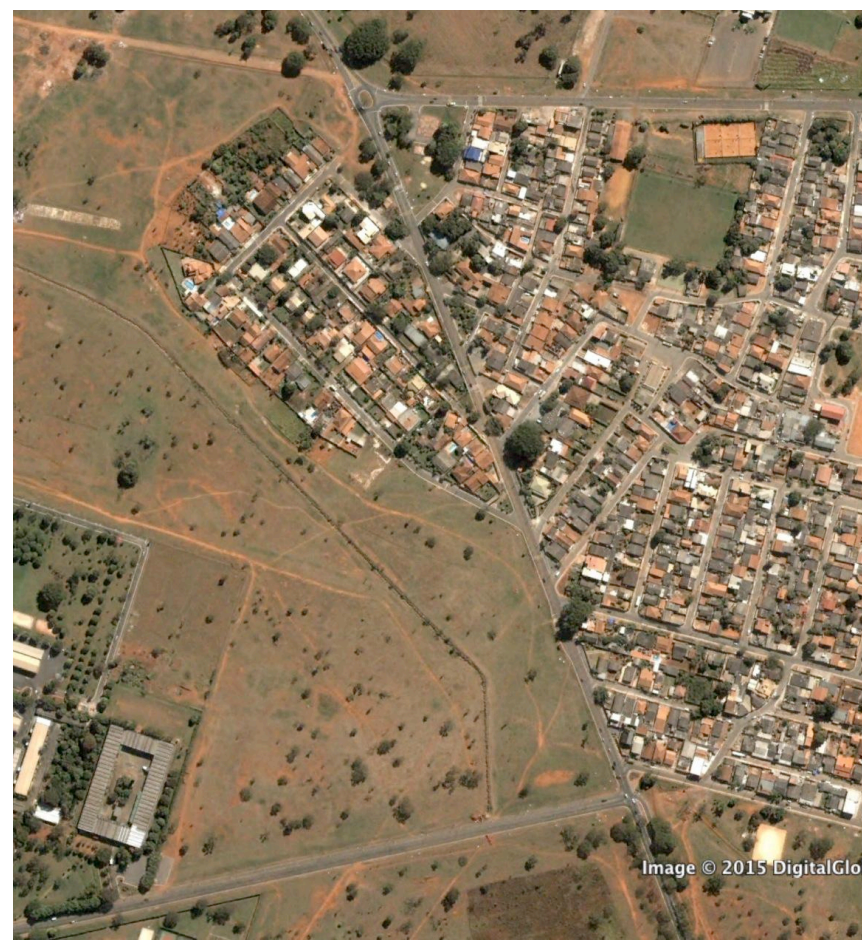

Figura 15a: Foto aérea de 17 de julho de 2004.

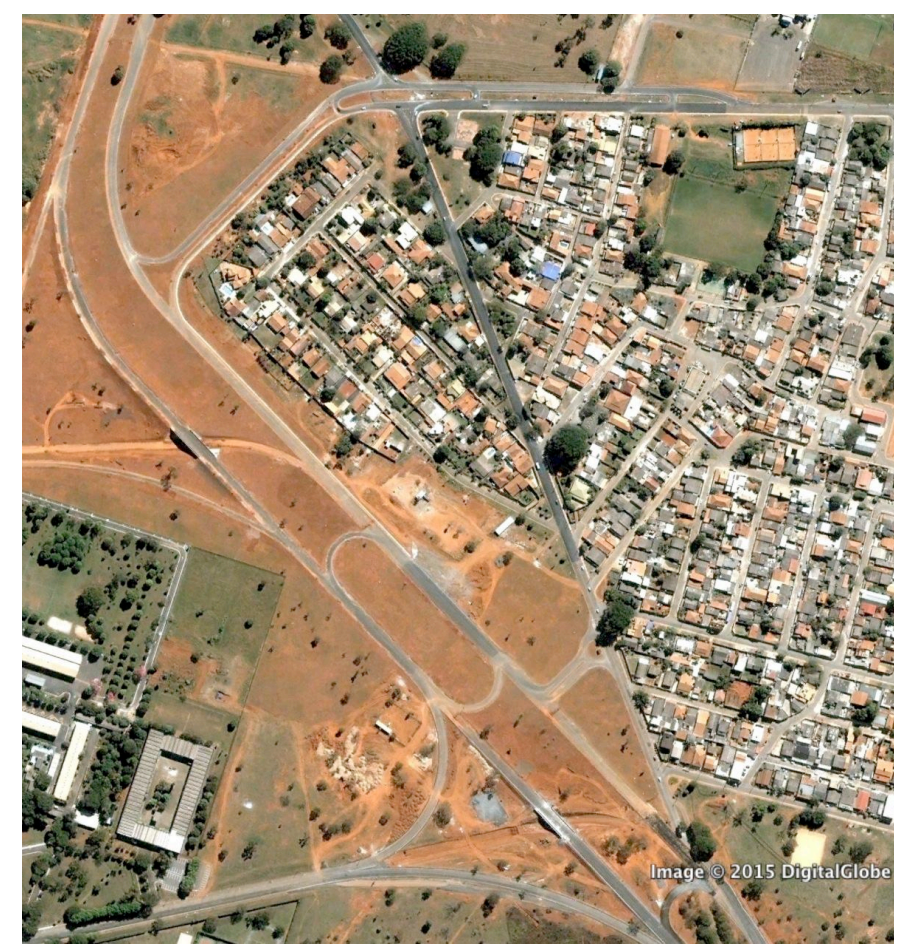

Figura 15b: Foto aérea de 25 de julho de 2005.

Fonte: Google Earth.

O Plano de Ação para a Vila Planalto, divulgado com o decreto $\mathrm{N}^{\mathrm{o}} 29.652$, de outubro de 2008, é um documento que contém o diagnóstico da situação do bairro nesse momento e um conjunto de propostas para o melhoramento urbano e a continuação do processo de regularização. Ele sugere como as ações mais importantes: a participação do Conselho Comunitário da Vila, os projetos de melhoramento dos espaços públicos, a revitalização do patrimônio histórico, a implantação de programas voltados ao turismo, a interrupção das obras irregulares, a criação de novo GEAP para implantação da regularização, a rearborização, a adequação da legislação do tombamento, a adequação das normas de parcelamento, usos do solo e gabaritos, e a entrega das escrituras dos lotes, entre outras.

\footnotetext{
${ }^{14}$ BRASILIATUR é uma empresa pública de sociedade limitada, sujeita ao regime jurídico das empresas privadas, foi criada com a Lei $N^{o} 3.982$ de 2007. A lei determina que sua função social é garantir o fomento da indústria do turismo no território do DF e que sua finalidade é explorar a prestação de serviços gerais na área do turismo.
} 
No ano seguinte, em 2009, é criado um Grupo Executivo (GE) responsável pela implantação do Plano de Ação que propõe a regularização dos lotes. O grupo foi composto pelos mesmos representantes do GT, incorporando-se um membro do DePHA. É importante observar que nem o Grupo de Trabalho (GT) nem o Grupo Executivo (GE) tiveram participação oficial de algum representante da comunidade.

\section{4) 2010 - 2015: A Vila Planalto gourmet.}

Este período começa aproximadamente em 2010, com os primeiros resultados concretos do GT e GE e do plano de ação da Vila Planalto. Apesar das diversas propostas sobre preservação do patrimônio propostas no plano, poucas se transformaram em projetos reais. Uma proposta que se transformou em ação foi o "Projeto Vila Planalto: gastronomia e cultura", da Secretaria de Turismo do GDF com apoio do governo federal. Esse projeto pretendeu fomentar a área como um reduto gastronômico, aproveitando a proximidade com a Esplanada dos Ministérios. Exalta-se o caráter autêntico e pitoresco da vila, assim como a existência de diversos grupos culturais. O objetivo do projeto era apoiar a produção associada ao turismo, consolidando a Vila Planalto como um "Polo Gastronômico e Cultural" (SECRETARIA DE TURISMO DO DISTRITO FEDERAL, 2010).

O projeto concentrou-se no fortalecimento da comercialização e no marketing dos 27 empreendimentos participantes, a maioria localizada na via L4 e próxima à Igreja Nossa Senhora do Rosário. Os empreendimentos, em geral pequenos locais, receberam capacitação e uma assessoria técnica e de identidade visual para melhorar o ambiente e a aparência dos negócios, principalmente restaurantes.
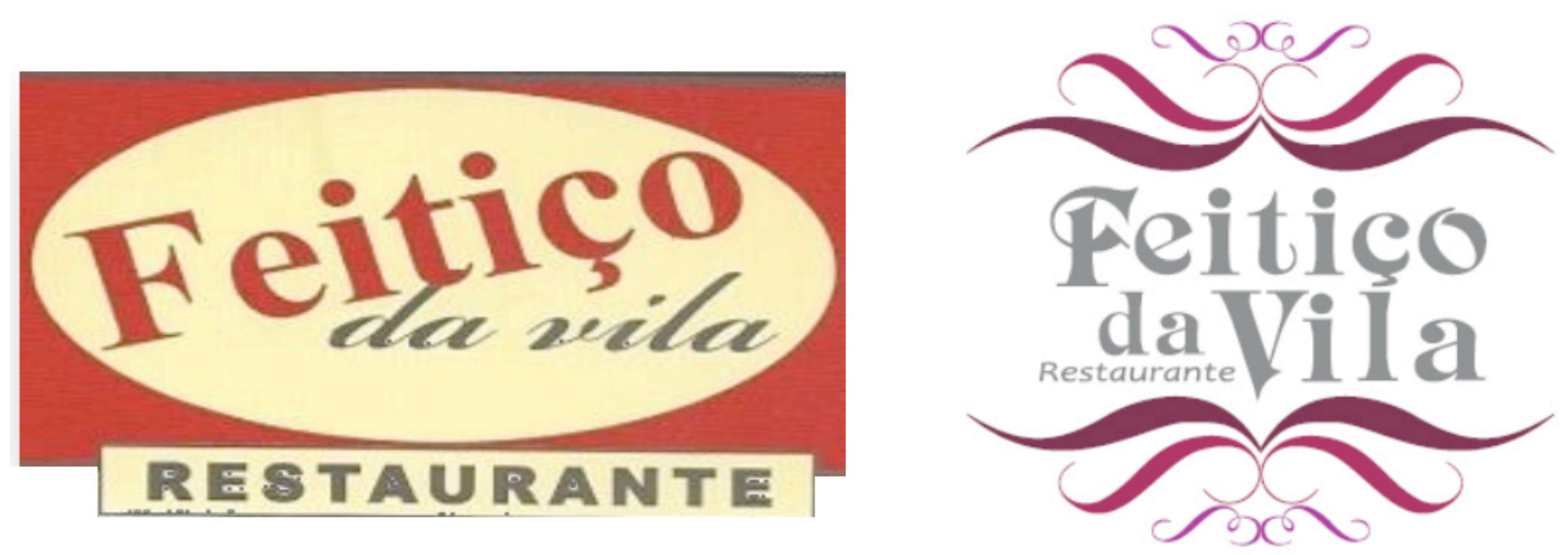

Figura 16: $\mathrm{O}$ antes e o depois da identidade visual do restaurante Feitiço da Vila.

Fonte: (SECRETARIA DE TURISMO DO DISTRITO FEDERAL, 2010). 
Na figura 16 apresenta-se um caso emblemático das transformações no perfil do comércio, com o restaurante Feitiço da Vila, administrado por uma pioneira e sua filha. A seleção de restaurantes concentrados na L4 foi complementada com o melhoramento das praças e dos largos localizados nessa via. Os melhoramentos consistiram em pavimentações, instalação de mobiliário urbano (iluminação, lixeiras, bancas e mesas) e vegetação.

O papel do Estado no bairro não se limitou ao projeto de gastronomia, ao melhoramento de espaços públicos e à sua omissão na fiscalização e preservação do patrimônio, também é importante considerar o entorno do bairro, já que na mesma época se consolidam as ocupações na orla do Lago Paranoá. Neste período são finalizadas as obras de hotéis, condomínios com apartamento de luxo e clubes privados de festas no Setor de Clubes Esportivos Norte (SCEN) e no Setor de Hotéis e Turismo Norte (SHTN), fato que promoveu a valorização do solo urbano próximo e transformou a Vila em uma possibilidade de mercado para a nova demanda de moradores de alta renda. A figura 17 mostra o hotel-condomínio "TransAmérica Classic The Sun", localizado no SCEN, um conjunto de 10 blocos com 572 apartamentos construídos pela empresa TransAmérica Hospitallity Group. 


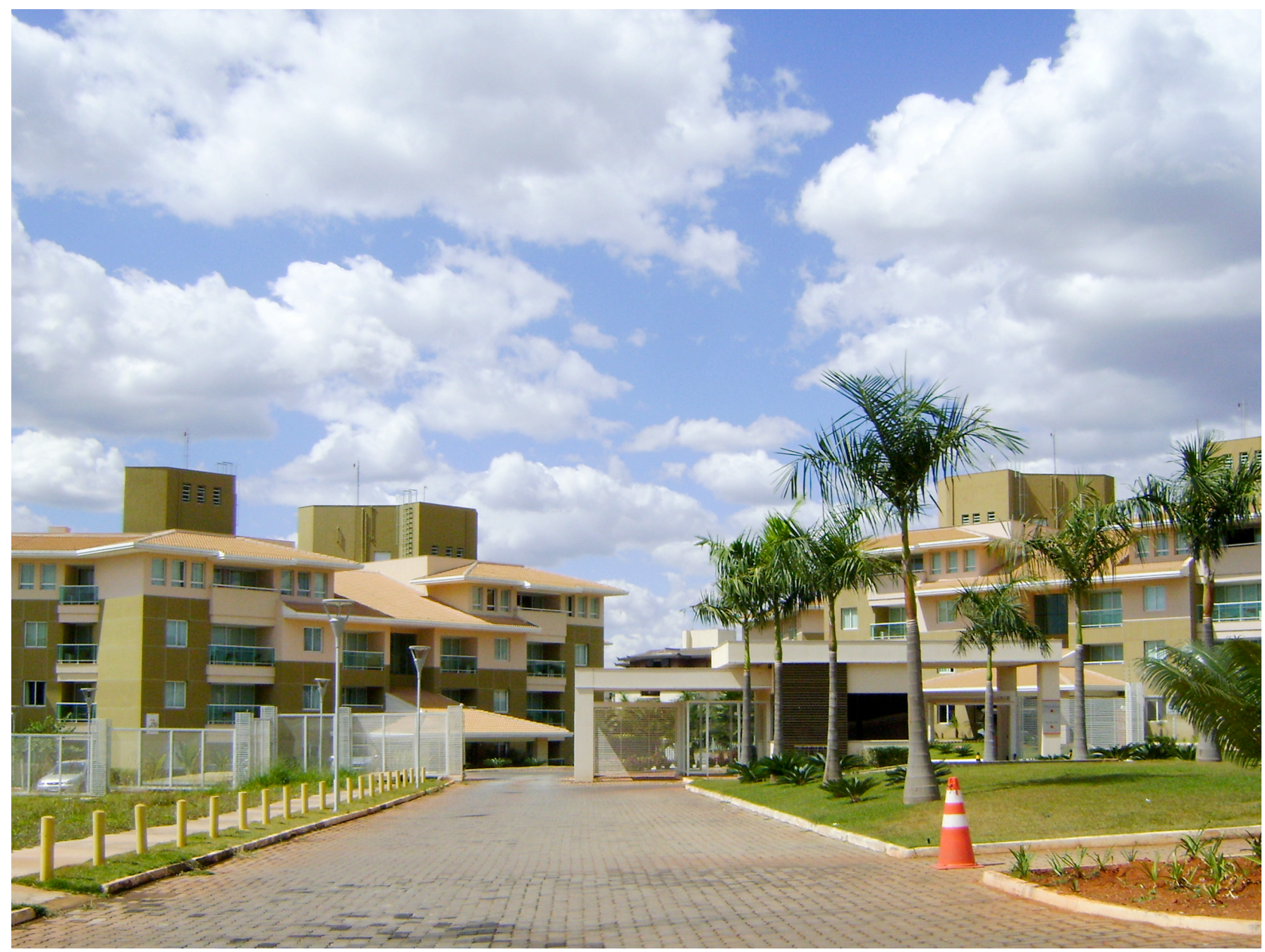

Figura 17: Fotografia de um dos hotéis-condomínios residenciais no SCEN.

Fonte: Arquivo pessoal, (03.08.2014).

No Censo de 2010 do IBGE (Instituto Brasileiro de Geografia e Estatísticas), na Vila Planalto, se contabilizaram 7.361 habitantes, que moravam em cerca 2.245 domicílios distribuídos em 1.424 lotes. Coêlho (2011), um ano depois, afirma que, nesse período, coabitam no bairro diferentes classes sociais, o que foi influente na estruturação do espaço. Para a autora, apesar das mudanças provocadas pelo tombamento e a fixação, a composição social da Vila Planalto é heterogênea, existindo situações de extrema pobreza junto com a presença crescente da classe média. A elitização do bairro seria um reflexo das relações entre classes, fazendo incerta a sobrevivência da população menos abastada (COÊLHO, 2011).

A excepcionalidade da Vila Planalto pode se dissolver com o processo de expulsão da população pioneira de Brasília, com o desrespeito pelas leis de preservação local e com as transformações de um espaço imprevisto, muito abandonado, num espaço cada vez mais valorizado. (COÊLHO, 2011, p. 17)

Segundo Coêlho (2011), no caso de Vila Planalto existiria uma contradição provocada pelo tombamento. Por um lado, está a dificuldade do processo de 
regularização fundiária, por ser um espaço provisório, que passou muito tempo ilegal e com uma origem majoritariamente popular. Por outro lado, após as dificuldades sofridas pela população para o reconhecimento do bairro, o espaço beneficia principalmente os setores de classe média e o funcionalismo público e privado, "que compram casas a preço do Lago Norte"15 e que alugam apartamentos ao preço das superquadras.

Em consequência, o tombamento representa um duplo fracasso, primeiro, por não garantir o direito à moradia para a população pioneira mais pobre; e segundo, por não garantir a conservação dos edifícios originais (COÊLHO, 2011). Para a autora: “A regularização reproduziu a mesma lógica da exclusão social e espacial à que parecia se opor no momento do reconhecimento histórico". As melhoras na infraestrutura urbana do bairro coincidem com a expulsão da população de menor renda para outras Regiões Administrativas ou inclusive fora do DF.

\begin{abstract}
A oficialização deste espaço contribuiu para sua valorização, como engendrou também, novas mudanças. Os processos de gentrificação, presentes em outros centros urbanos, foram igualmente presentes em Brasília, no casa da Vila Planalto. (COÊLHO, 2011, p. 18)
\end{abstract}

Nos anos 2011 e 2012, há um ressurgimento dos movimentos sociais, que reivindicam a entrega das escrituras dos lotes. A AMVP solicita formalmente à SHIS a abertura do processo de regularização fundiária. Frente à expansão das residências, no denominado Setor de Chácaras, seus moradores organizados na Associação de Produtores da Vila Planalto (APVP) entram na justiça com um pedido de reconhecimento do direito à regularização. Esse pedido foi julgado improcedente pelo TJDFT em 2014.

Em 2012 o Ministério Público do DF (MPDF), através da Procuradoria Geral, recomendou à TERRACAP - nesse momento proprietária dos lotes - adotar medidas para restaurar, reconstruir e conservar os prédios e espaços segundo o Plano de Ação para a Vila Planalto. O procurador também alerta para as observações feitas pela missão da UNESCO no ano anterior sobre a expansão sem controle dos limites da área ocupada e o aumento da altura das edificações, que fere a escala bucólica. A UNESCO recomendou a revitalização da Vila Planalto além do controle e aplicação da regulamentação urbana.

${ }^{15}$ (COÊLHO, 2011, p. 18) 
Durante o governo de Agnelo Queiroz (PT), em 2013, o executivo enviou o projeto de lei $n^{0} 1.514$, que dispõe sobre a alienação de imóveis na Vila Planalto. Esse projeto, transformado em lei depois, atende a uma reivindicação de mais de 25 anos dos moradores. Contrária às recomendações feitas por Lucio Costa em Brasília Revisitada, a lei permite a entrega das escrituras dos lotes e a alienação das unidades imobiliárias da Vila Planalto. Na Câmara Legislativa do DF o projeto teve como relator o deputado distrital Roney Nemer (PMDB). Em 12 de julho de 2013 foi promulgada a Lei $\mathrm{n}^{\mathrm{o}} 5.135$, que autoriza o Poder Executivo a alienar as propriedades dentro do polígono de tombamento e no acampamento EBE. A lei estabelece três critérios para a obtenção das propriedades, que serão entregues por: 1) doação, para moradores fixados com anterioridade pelo Poder Público, 2) venda direta, pelo preço de avaliação do imóvel para ocupantes não fixados, e 3) licitação, assegurando preferência para os legítimos ocupantes ou aberta para os lotes vazios.

A Procuradoria-Geral de Justiça do DF ajuizou uma Ação Direta de Inconstitucionalidade (ADI), contestando e Lei $n^{\circ} 5.135$, que determina a regularização fundiária na Vila, e sustentando que a lei incorreria em "vício de forma" por ser aprovada como lei ordinária, mas tratando de assuntos de lei complementar. Ressalta que a lei orgânica do DF determina que todos os bens públicos devem ser licitados de forma aberta, o que impediria a doação, e também aponta que a lei seria uma nova tentativa de desafetação de imóveis públicos julgada inconstitucional em 2005. O caso foi acompanhado por várias organizações sociais do bairro, como a Creche Pioneira, a Associação dos Idosos Renascer dos Pioneiros da Vila Planalto, o Fórum Democrático e Popular da Vila Planalto (FDPVP), a Associação Grêmio Recreativo Carnavalesco União da Vila Planalto e a Associação de Moradores da Vila Planalto (AMVP). Finalmente, em junho de 2014 o TJDFT julgou a ADI improcedente e declarou a lei formalmente constitucional, permitindo a venda direta ou doação dos imóveis a seus legítimos ocupantes.

A cerimônia de entrega das primeiras escrituras aconteceu no dia 21 de março de 2014 na Creche Pioneira. O evento contou com a presença de vários políticos, entre eles o Governador Queiroz, o Vice-governador Filipelli, o Secretário de Habitação Magela, os deputados distritais Roney Nemer e Cristiano Araújo, ademais de dirigentes de organizações sociais, principalmente da AMVP e do FDPVP. Na ocasião, foram entregues as primeiras 22 escrituras a pioneiros (a maioria morava na Vila há mais de 45 anos); em total o governo esperava entregar 1.200 escrituras. 


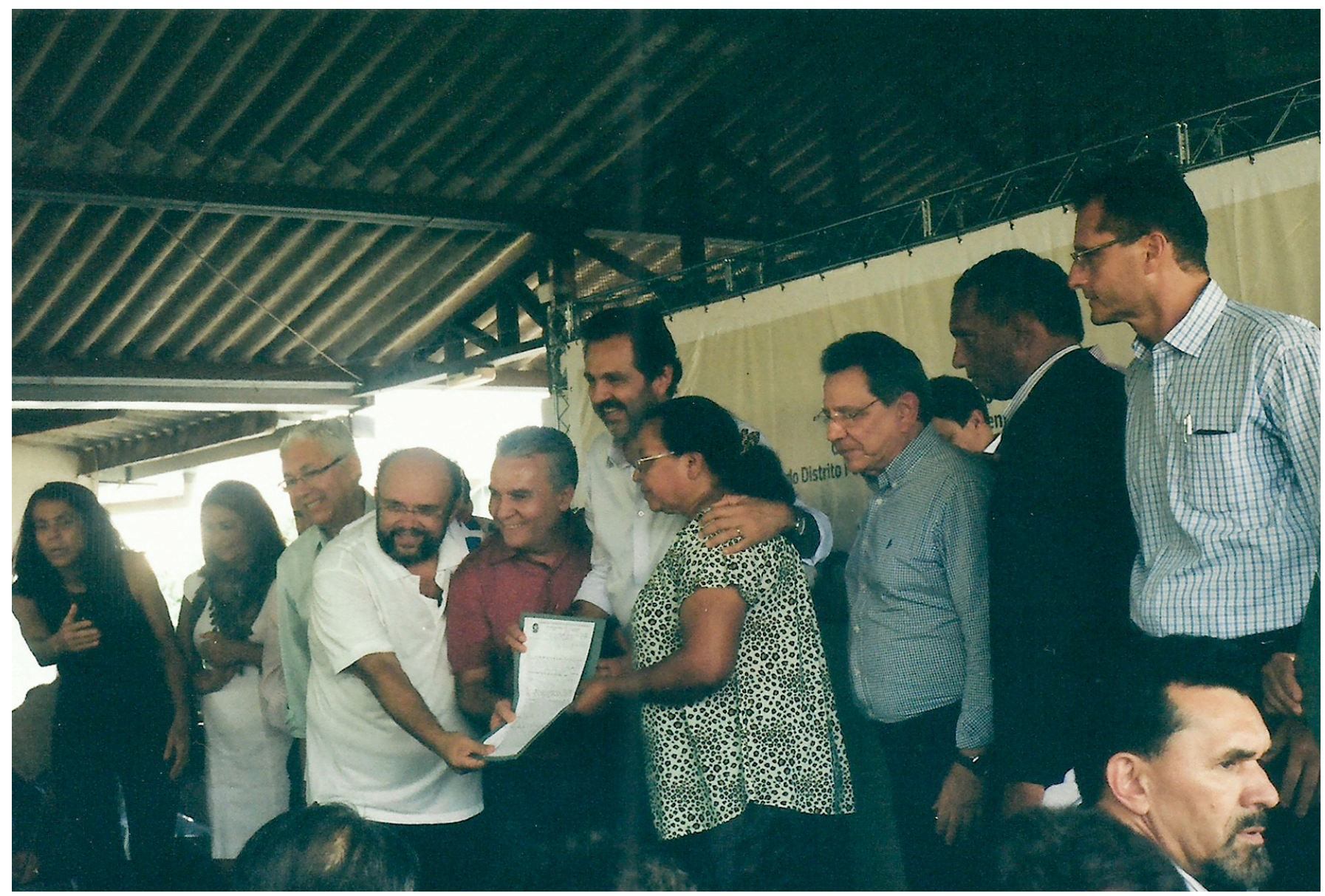

Figura 18: Fotografia da cerimônia de entrega das escrituras na Vila Planalto.

Fonte: Arquivo pessoal, (21.03.2014).

Com a mudança de governador do DF, a continuação da regularização ainda é incerta, e o processo é levado adiante pela CODHAB/DF (Companhia de Desenvolvimento Habitacional do Distrito Federal). Nas últimas reuniões entre moradores e representantes do governo, ocorridas em 2 de dezembro de 2014 e 28 de maio de 2015, as principais reivindicações vem da parte do FDPVP, que agrupa vários moradores que compraram o direito de uso de pioneiros, portanto não fixados, preocupados com os valores que terão de pagar novamente pela propriedade. Segundo a CODHAB, o valor aproximado seria de $\mathrm{R} \$ 611$ por $\mathrm{m}^{2}$, podendo ser pago em 240 meses. Para as autoridades, os principais entraves para a continuação do processo em muitas unidades é o descumprimento das normas urbanísticas da região e moradias construídas ocupando o espaço público. Para resolver esses problemas a CODHAB propõe a elaboração de um Projeto de Lei Complementar (PLC) para adequar as normas de uso do solo e gabarito e para desafetação de área pública. 
$\mathrm{Na}$ atualidade, o bairro ainda exibe grande diversidade urbana com diferentes lotes, casas, barracos, edifícios, quarteirões, ruas, ruelas, becos, praças e largos, que variam em dimensões, formas, características, usos, e apropriações. Do patrimônio construído foi pouco o que sobrou, a necessidade das famílias de ampliar suas casas e as condições do mercado imobiliário provocaram a demolição da maioria das casas de madeira. Em 2007, um levantamento da SEDUMA contabilizou apenas 19 das 81 edificações reconhecidas como de interesse histórico que deveriam contar com uma preservação rigorosa. Em 2009, o uso desta materialidade (a madeira) correspondia a $8,9 \%$ dos domicílios, enquanto apenas $5,3 \%$ conserva a edificação original. Hoje, as casas originais contabilizam menos de 10 unidades e quase todas sofreram intervenções posteriores. As edificações não residenciais que ainda sobrevivem são: o Conjunto Fazendinha no Acampamento Pacheco Fernandes, em péssimo estado de conservação e com algumas construções interditadas pela Guarda Civil, e a reconstruída Igreja do Rosário.

Em relação ao mercado imobiliário, existe ampla oferta de aluguéis de apartamentos e quitinetes, assim como venda de lotes e casas que atraem nova população para o bairro. A oferta de aluguéis que se concentra em apartamentos construídos dentro dos lotes está "aquecida", com valores que superam os das asas Norte e Sul. Em sete visitas realizadas a apartamentos para aluguel durante o mês de julho de 2014, constatou-se ampla oferta de preços segundo a qualidade do imóvel. Por uma parte, alugam-se pequenas quitinetes em prédios que parecem cortiços contemporâneos, onde em um lote de $100 \mathrm{~m}^{2}$ podem ser construídas, em 2 ou 3 andares, mais de 20 unidades para alugar com deficientes condições de habitabilidade (iluminação e ventilação). Para essas opções, os preços variam de R $\$ 700,00$ a R \$ 900,0 mensais. Apartamentos de 1 quarto são alugados por R\$ 1.500 aproximadamente; a oferta de apartamentos de 2 ou 3 quartos é mais reduzida; para 2 quartos, por exemplo, o preço se situa entre $\mathrm{R} \$ 1.800,00$ e $\mathrm{R} \$ 2.200,00$. Por outra parte, foram visitados hotéis disfarçados de apartamentos, chamados de "Residencial", onde por R\$ 2.300,00 mensais é possível alugar um quarto mobiliado para uma pessoa com serviços de limpeza. 


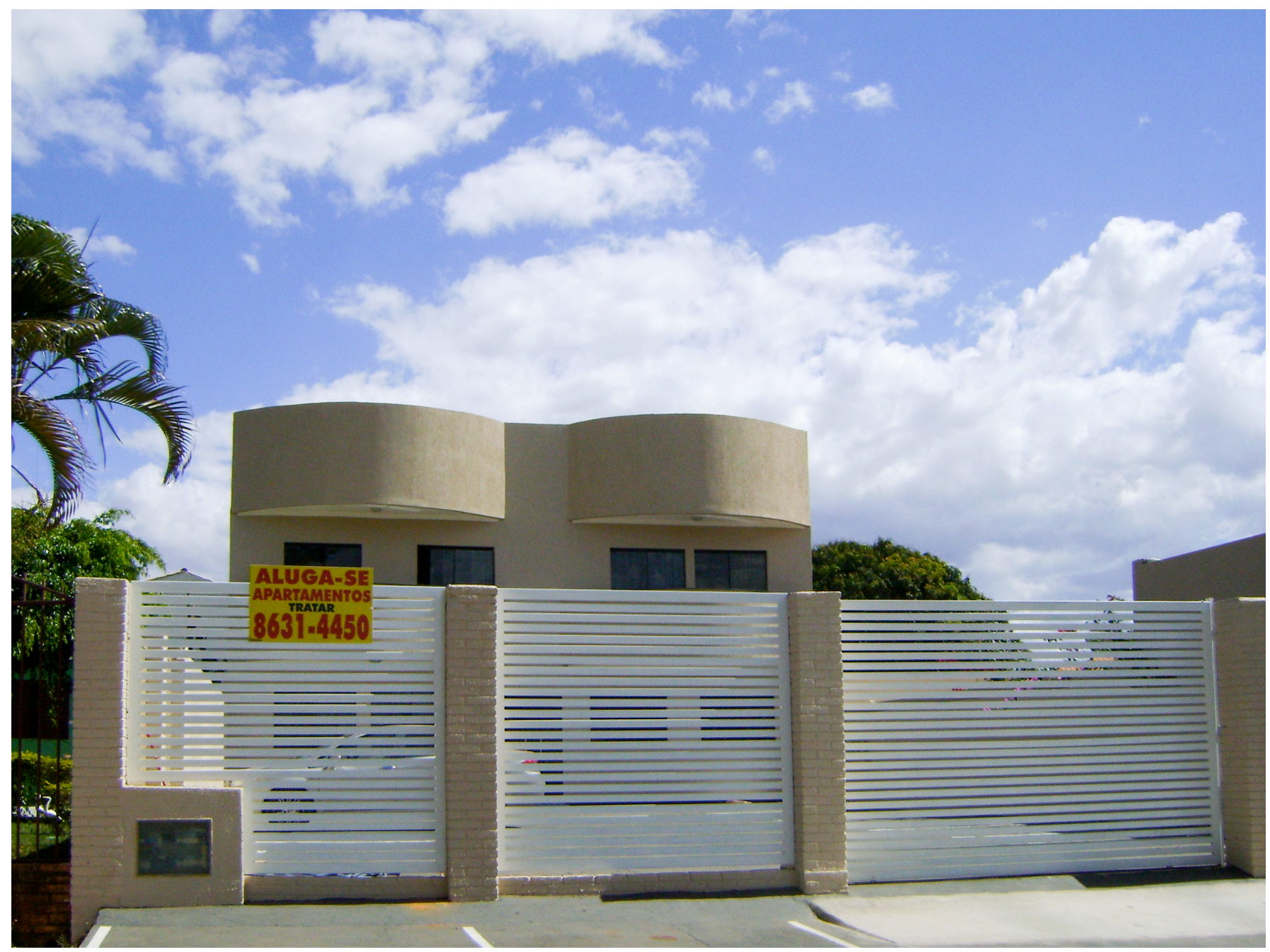

Figura 19: Prédio de apartamentos para aluguel no acampamento Pacheco Fernandes.

Fonte: Arquivo pessoal, (03.08.2014).

Os empreendimentos descritos estão distribuídos por todo o bairro, inclusive podem coincidir em um mesmo lote - com acessos separados - um prédio de precárias quitinetes com outro de amplos apartamentos de dois quartos. A maioria dos empreendedores dos imóveis visitados são os "proprietários" dos lotes, dos quais alguns são funcionários públicos aposentados, que chegaram há 20 ou 25 anos, e que a partir de 2006 capitalizaram suas aposentadorias para construir unidades imobiliárias para viver e gerar renda com aluguel.

A compra de casas tem preços elevadíssimos. Na internet é possível encontrar residências à venda por mais de 2 milhões de reais. Em abril 2013, o maior valor do metro quadrado do solo urbano de Brasília se encontrava na Vila Planalto, chegando a um valor de $\mathrm{R} \$ 13.000,00 / \mathrm{m}^{2}$ (LAURIANO, 2015). 


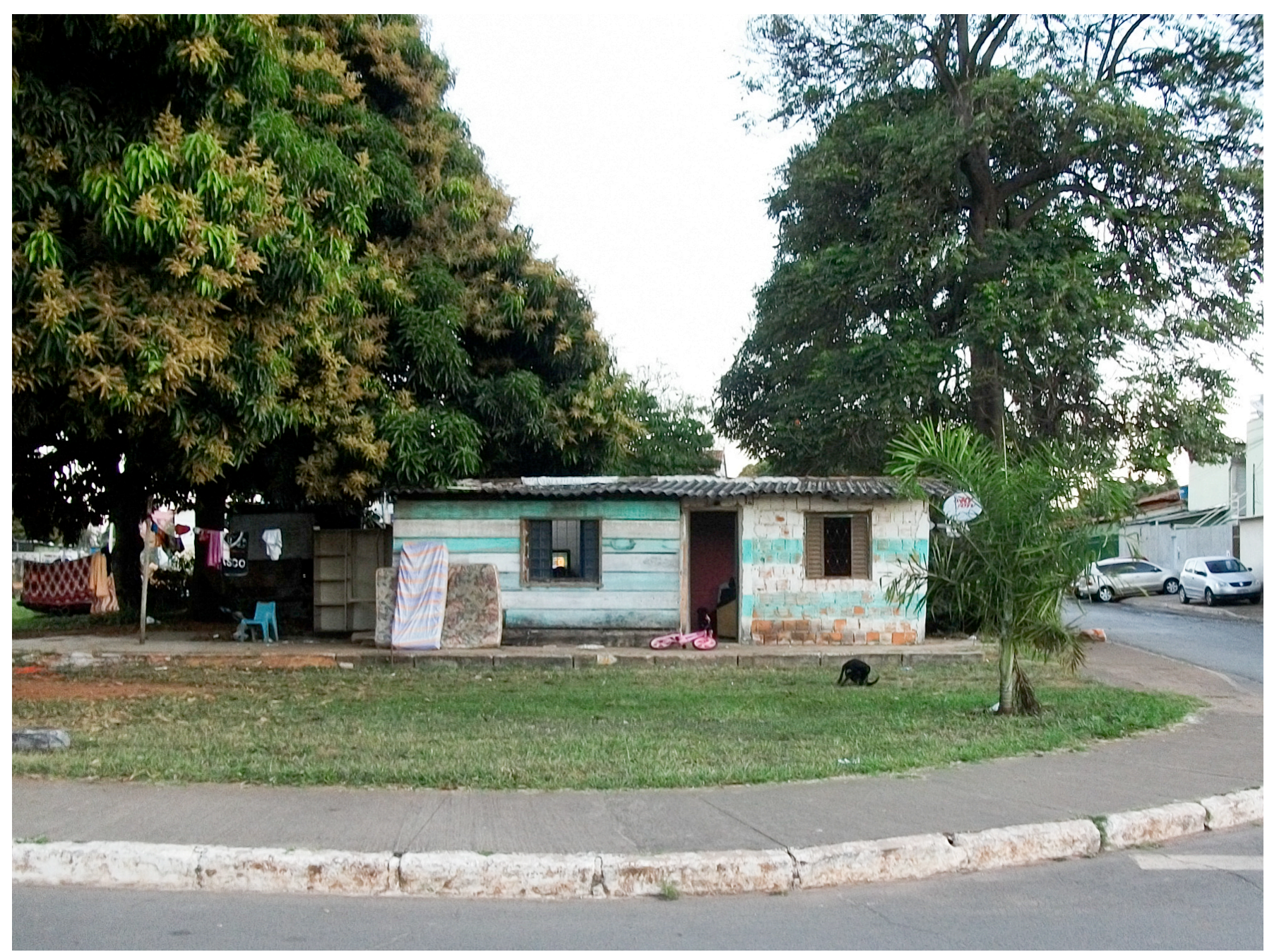

Figura 20: Casa de madeira remanescente situada dentro da Praça Rabelo.

Fonte: Arquivo pessoal, (04.12.2009).

No bairro, observa-se um enobrecimento dos usos nas bordas do polígono tombado, enobrecimento causado pela ampla oferta de bares e restaurantes mais requintados, de preços elevados em comparação ao comércio localizado em setores internos do bairro. A gentrificação residencial é a cada momento mais intensa, mas não completa. No acampamento Tamboril, o setor de edificações mais homogêneo e de melhores condições de conservação, ainda persistem duas casas mais humildes em condições mais precárias. Nos demais acampamentos, ainda é possível reconhecer que no miolo do bairro as famílias mais pobres resistem, porém, são a minoria e configuram apenas algumas fissuras numa estrutura predominantemente de classe média. Um exemplo disso é a casa apresentada na figura 20. 


\section{População e políticas urbanas}

A seguir apresentamos os resultados da análise dos dados demográficos dos Censos de 2000 e 2010 e do levantamento feito pela Codeplan em 2007. Os valores dos Censos foram comparados por ano e por setores censitários. Entre 2000 e 2010, a estrutura dos setores censitários correspondentes ao polígono da Vila Planalto foi subdividida em mais partes. Para o ano 2000 se consideram cinco setores (264, 265, 266, 267 e 268). Em 2010 se acrescentam quatro setores (358, 359, 422 e 423), somando nove. Para alguns dados, com o fim de incorporar os novos domicílios surgidos nos condomínios à beira do Lago Paranoá, no SHTN e SCEN, se consideram os setores adjacentes ao polígono da Vila, totalizando 22 setores.

O gráfico 1 mostra a variação na condição de ocupação dos domicílios na Vila Planalto. Os residentes que consideram seu imóvel como próprio diminui de $58 \% \mathrm{em}$ 2000 para 53\% em 2010. Por uma parte, embora até 2010 ninguém tivesse recebido a escritura dos lotes, mais da metade dos residentes considera o imóvel como próprio. Por outra parte, quem considera seu domicílio como cedido, correspondente à condição real dos lotes através de concessão de uso, também diminui de 15\% para 10,7\%. Em contraste, os domicílios em condição de alugados aumentam de 24\% para 36,3\%. Esse aumento expressa uma mudança importante na composição do bairro, tanto na estrutura social como espacial, demonstrando o surgimento de apartamentos e quitinetes construídos dentro dos lotes. A diversificada oferta de aluguéis atende principalmente a dois grupos, por uma parte, apartamentos de padrão médio e alto para famílias de rendas mais altas ligadas ao funcionalismo público; e, por outro, quartos e quitinetes mais precários para trabalhadores manuais relacionados à área de serviços.

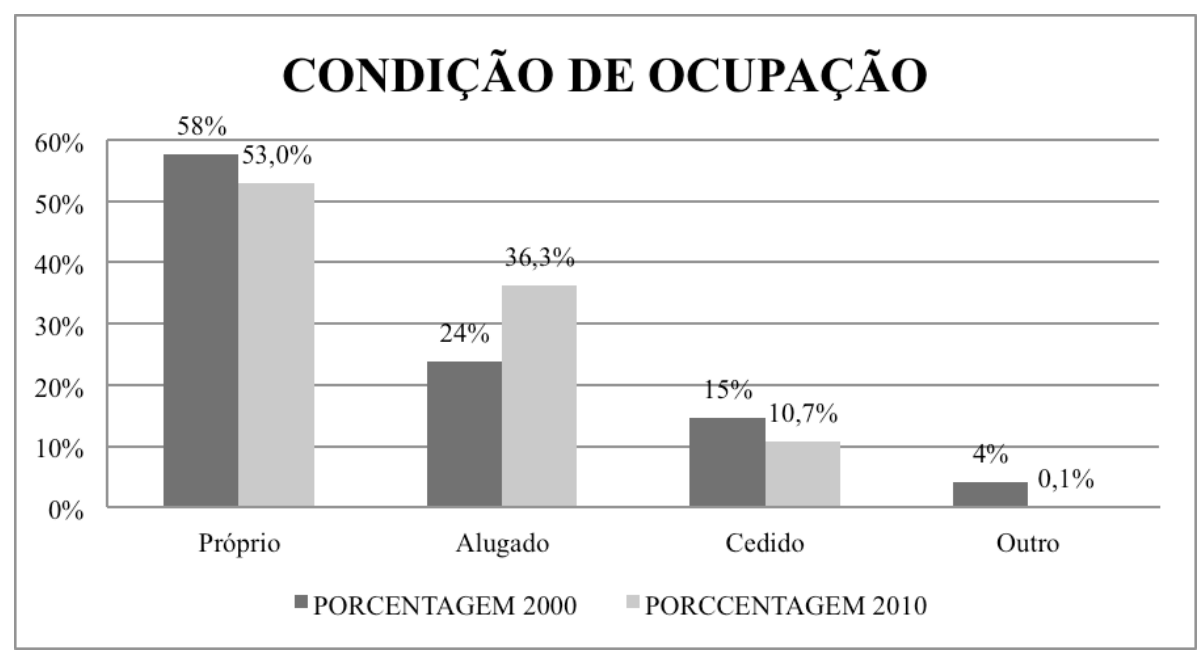

Gráfico 1: Condição de ocupação dos domicílios na Vila Planalto.

Fonte: Censo IBGE 2000, 2010. 
Para Holanda (2013), a Vila Planalto representa um contraponto ao mito de igualdade social proposto por Lucio Costa para as superquadras. A diversidade nas rendas dos residentes num espaço localizado dentro do Plano Piloto seria uma ironia. Enquanto nas superquadras (planejadas por Costa) estão representadas faixas de rendas mais ou menos homogêneas, na Vila Planalto (espaço provisório) o desempenho sociológico permite a presença de diferentes faixas de rendas. Assim, apesar da privilegiada localização, o perfil de faixas de renda da Vila resulta similar ao perfil do Distrito Federal, o que seria um microcosmo da metrópole.

Os gráficos 2a e 2b comprovam o proposto pelo autor. Em 2010, os residentes com as rendas mais baixas (até dois salários mínimos) são a maioria, representando quase o $50 \%$ da população tanto no DF como na Vila Planalto. Ao contrário, as mais altas rendas, acima de 20 salários mínimos, representam a minoria da população com $5,1 \%$ no DF e $2,5 \%$ na Vila.

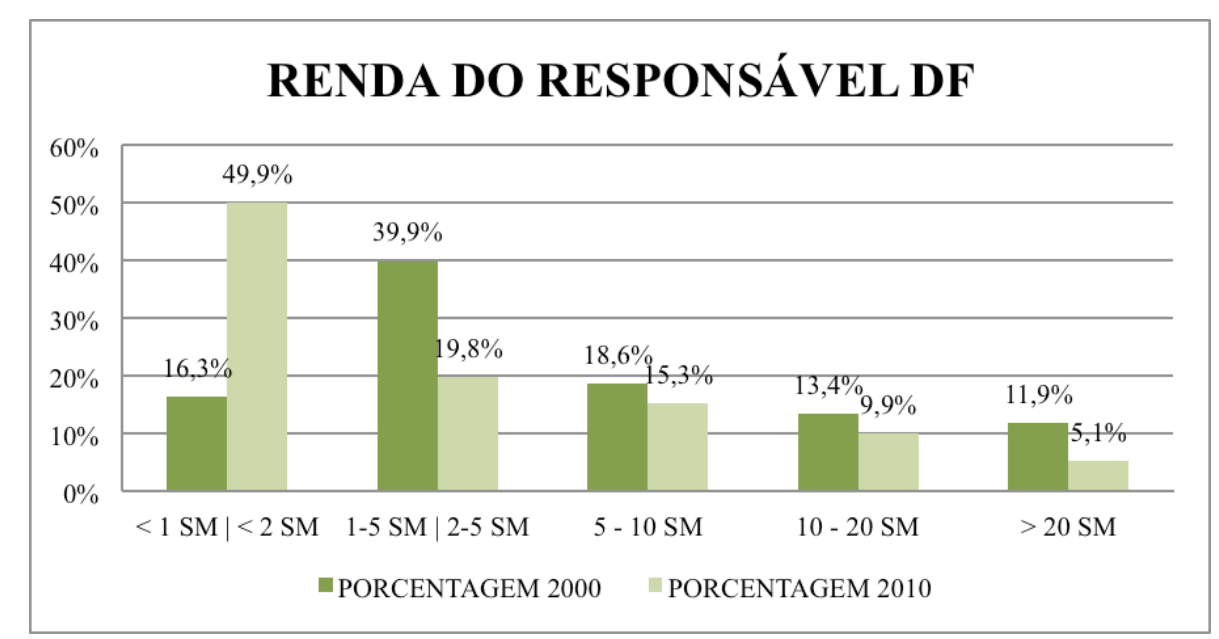

Gráfico 2a: Renda do responsável pelo domicílio no DF.

Fonte: Censo IBGE 2000, 2010. 


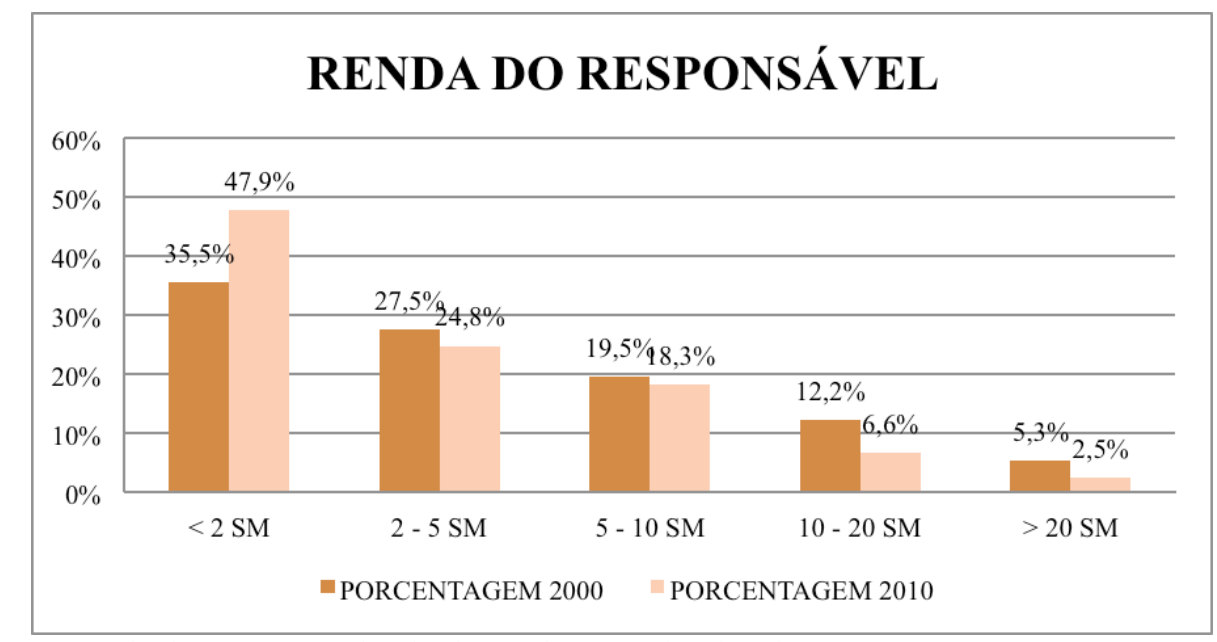

Gráfico 2b: Renda do responsável pelo domicílio na Vila Planalto.

Fonte: Censo IBGE 2000, 2010.

Do ano 2000 para 2010, o IBGE mudou a divisão das rendas para os estados e o DF. Em 2000, a faixa de renda mais baixa é até um salário-mínimo, a seguinte faixa vai de mais de um até cinco salários-mínimos. Em 2010, a primeira faixa é até dois saláriosmínimos, enquanto a segunda vai de dois até cinco salários. Apesar dessa mudança, é possível observar uma correlação nas variações das faixas de renda entre 2000 e 2010 no DF e na Vila Planalto. Nos dois casos existe uma tendência: quanto maior é a renda do responsável, menor é sua presença no bairro.

Essa tendência parece surpreendente quando contrastada com a transformação da paisagem urbana. Como destaca Holanda (2013), o bairro estaria se tornando mais popular com a chegada de população mais pobre de até 2 salários-mínimos - que passa de 35,5\% em 2000 para 47, 9\% em 2010 - e a saída dos residentes mais ricos (mais de $20 \mathrm{SM}$ ) - que caem de 5,3\% para 2,5\% - e das classes médias altas (entre 10 e $20 \mathrm{SM}$ ), que caem de $12,2 \%$ para $6,6 \%$.

Os novos residentes seriam trabalhadores manuais que chegam para morar de aluguel em quitinetes ou "puxadinhos" mais informais, com o fim de se estabelecer próximos aos postos de trabalho. Durante a investigação foi possível conhecer o caso particular de uma moradora da Vila que trabalhava na limpeza de um dos hotéis na orla do Lago. Porém, assim como este caso não representa uma generalidade, os dados do Censo não são absolutos, sendo necessária uma visão mais ampla e o desenvolvimento de trabalho de campo para comprovar ou refutar a gentrificação no bairro. 
Para compreender melhor esses dados, ampliamos o escopo de análise e consideramos os setores censitários contíguos ao polígono de tutela que delimita a Vila. Em 2000, correspondem à Vila Planalto e entorno nove setores, e em 2010 estes representam 22 setores, segundo o IBGE. É importante observar que em 2000 ainda não existiam os condomínios na borda do lago, mas que aparecem no censo de 2010.

O gráfico 3, que considera e renda do responsável dos domicílios na Vila Planalto e entorno, ou seja, 9 setores censitários em 2000 e 22 setores em 2010, apresenta grandes diferenças quando consideramos apenas o interior do bairro. A variação de um censo a outro é inversa: as rendas mais baixas caem: a faixa até 2 SM de 34,8\% em 2000 para $32,3 \%$ em 2010 , e a faixa de 2 a 5 SM passa de $28,1 \%$ para $18 \%$. Ao contrário, a faixa de renda mais alta (acima de $20 \mathrm{SM}$ ) aumenta de 5,9\% para 15,4\%.

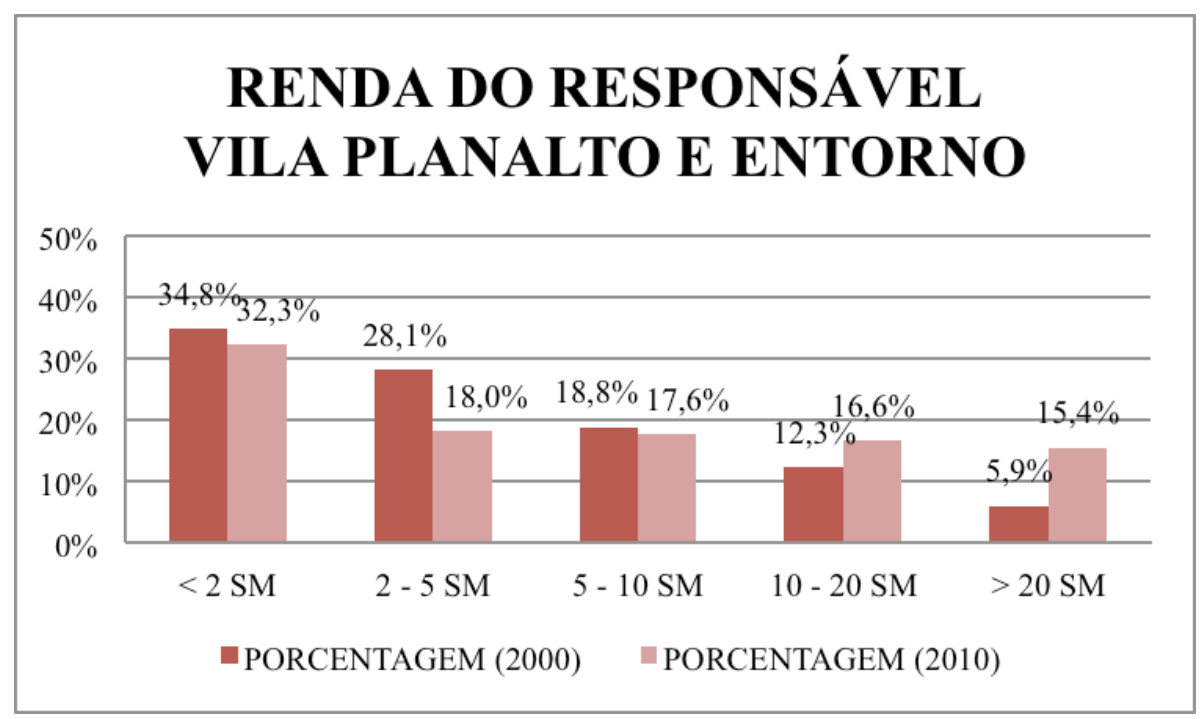

Gráfico 3: Renda do responsável na Vila Planalto e entorno.

Fonte: Censo IBGE 2000, 2010.

Os valores do gráfico 3 permitem inferir que o aumento das rendas mais altas se explica pelas novas ocupações entre a EHTN e o Lago Paranoá. Condomínios residenciais e apartamentos disfarçados de hotéis estariam atraindo uma população de alta renda que reside nos apartamentos e se serve da Vila Planalto, ocupando seus restaurantes mais requintados e empregando alguns de seus residentes.

Os gráficos $4 \mathrm{a}$ e $4 \mathrm{~b}$ evidenciam a influência dos condomínios fora dos limites do bairro. Em 2000, quando não existiam, as variações nas rendas entre o polígono da Vila versus o polígono com o entorno é mínima. Já em 2010 as diferenças são expressivas. Como mostra o gráfico 4b, no Censo de 2010, dentro da Vila as rendas de até $2 \mathrm{SM}$ representam 47,9\%, já somando o entorno, apenas são 32,3\%. A faixa de 2 até $5 \mathrm{SM}$ 
também cai de $24,8 \%$ para $18 \%$. Ao contrário, as rendas mais altas, acima de 20 SM, dentro do bairro são apenas 2,5\%, mas quando incorporamos o entorno corresponde a 15,4\%. Os domicílios com renda entre 10 e 20 SM também aumentam de 6,6\% para $16,6 \%$.

Essa mudança na escala de análise dos dados de renda permite observar que, quando ampliamos o recorte incorporando áreas adjacentes ao bairro a tendência é a oposta da situação interna: entre 2000 e 2010 as rendas mais baixas caíram enquanto as rendas mais altas aumentaram sua presença no bairro e no entorno.

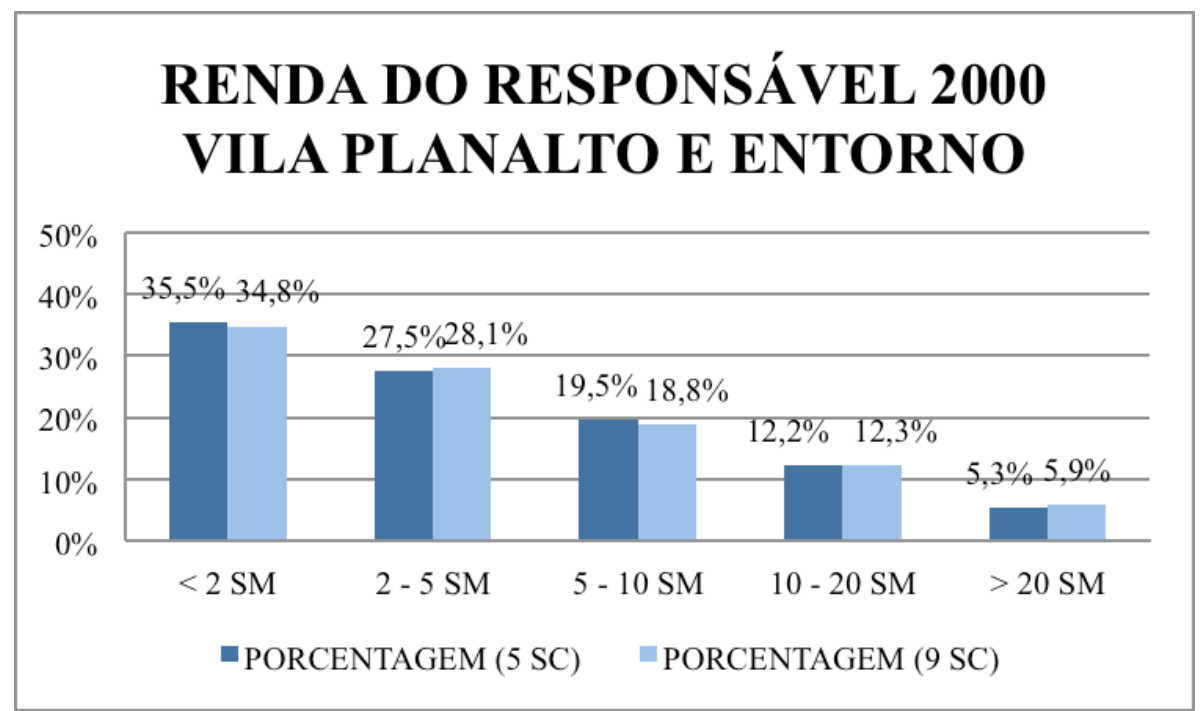

Gráfico 4a: Renda do responsável na Vila Planalto e entorno em 2000.

Fonte: Censo IBGE 2000.

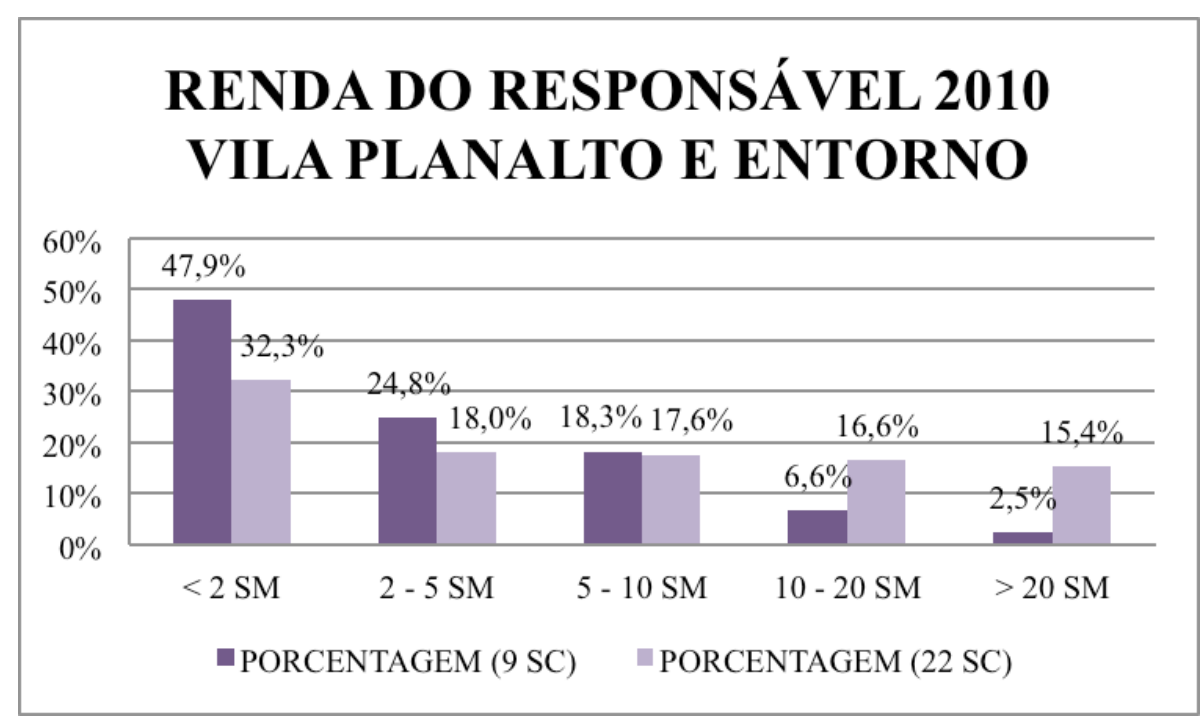

Gráfico 4b: Renda do responsável na Vila Planalto e entorno em 2010.

Fonte: Censo IBGE 2010. 
Com a análise dos dados do Censo ainda não é possível afirmar que existe gentrificação residencial na Vila Planalto, porque a chegada das classes médias e altas no interior do bairro é ainda pouco expressiva. Mas a problemática da gentrificação está presente em vários aspectos como: a abertura de estabelecimentos comerciais, lojas, restaurantes, bares e academias dentro do bairro, e a construção de conjuntos de luxo com a privatização da orla do lago em seu entorno imediato.

Na figura 21 é possível observar as diferenças internas na distribuição das rendas por acampamentos e nos setores censitários do entorno.

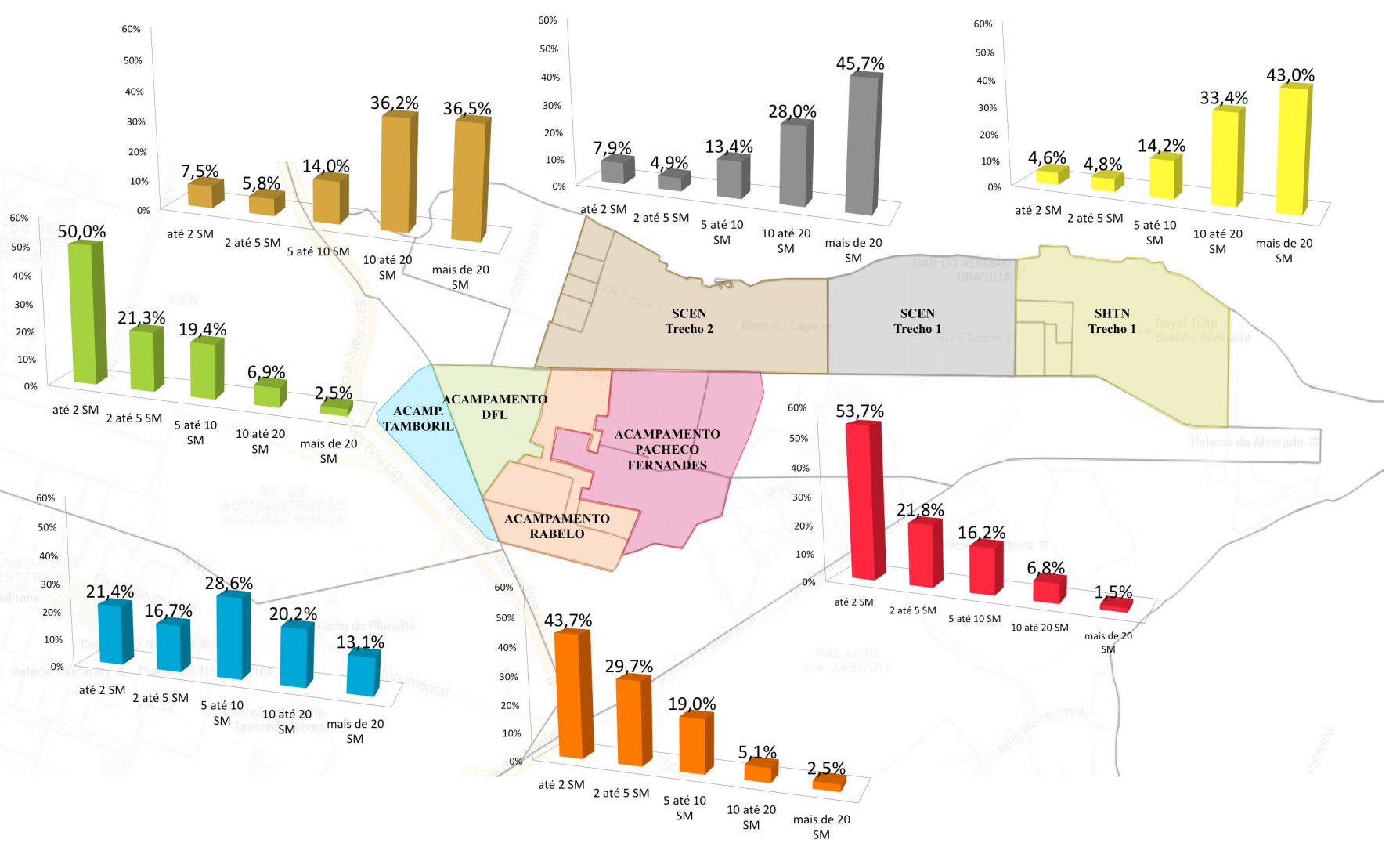

Figura 21: Mapa da distribuição das rendas do responsável por domicilio na Vila Planalto e entorno.

Fonte: Elaboração própria, com base no Censo IBGE, 2010.

Um aspecto da gentrificação pouco abordado na arquitetura é a questão racial. A raça constitui um aspecto importante na sociologia urbana relacionado às estruturas de classe e de segregação. Lees et al. (2010) considera a gentrificação como um processo de transformação de classe, mostrando investigações que surgiram em meados dos anos 
1980 voltadas a entender as relações entre classes e outras dimensões da segregação como, gênero, sexualidade e raça ou etnicidade. Alguns estudos demonstram como a expressão da desigualdade de classe nos bairros - entendida como gentrificação - cria áreas urbanas onde o espaço é reconfigurado e contestado, uma situação que se manifesta nos elementos das diferenças sociais, em outras palavras, criam-se espaços de disputa.

Lees et al. (2010) mencionam o caso dos Estados Unidos, onde a imagem estereotipada que as pessoas têm da gentrificação é a dos brancos "yuppies" indo para bairros de baixa renda com altas concentrações de minorias étnicas. Segundo os autores, essa perspectiva seria negligente com o fenômeno da gentrificação negra. Neil Smith (1987), a partir de pesquisas no Harlem, observa que a maioria das pessoas envolvidas com investimentos do Central Harlem eram negras e não gentrificadores brancos. $\mathrm{O}$ autor considera os aspectos raciais fundamentais na segregação de classe e propõe a relação com os aspectos da renda do solo. Para Smith (1996) existem duas forças predominantes na disputa pelo espaço. Primeiro, uma força funcional determinada pelo uso da terra; e segundo, uma força social, determinada pela classe social ou a raça.

Sem constituir o foco principal desta pesquisa, parece importante considerar a composição do bairro segundo a raça ou cor dos residentes. Esses dados, obtidos do último Censo do IBGE e do levantamento feito pela Codeplan em 2007, não são definitivos porque a autodeclaração incorpora subjetividades difíceis de dimensionar.

O gráfico 5 apresenta uma comparação entre moradores, segundo sua raça ou cor declarada no Censo de 2010, do interior da Vila Planalto versus a Vila Planalto considerando seu entorno. 


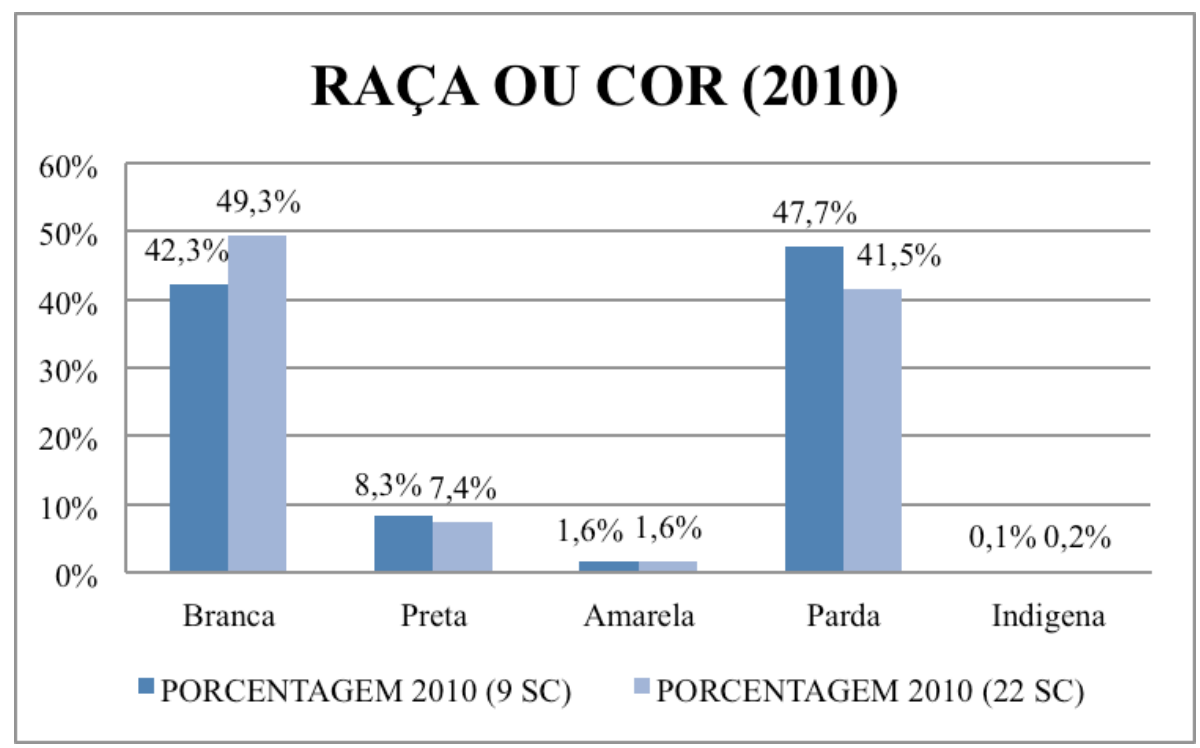

Gráfico 5: Raça ou cor declarada na Vila Planalto e entorno.

Fonte: Censo IBGE 2010.

No gráfico 5 é possível observar uma diferença importante na população branca e parda, quando comparamos o interior do bairro com seu entorno. Em 2010 os moradores autodeclarados como brancos na Vila Planalto correspondem ao 42,3\%, já considerando seu entorno ascendem a 49,3\%. Em contraposição, a população que se identifica como parda ou negra cai. Pardos diminuem de 47,7\% dentro da Vila para $41,5 \%$ com o entorno, e pretos ou negros passam de $8,3 \%$ para $7,4 \%$.

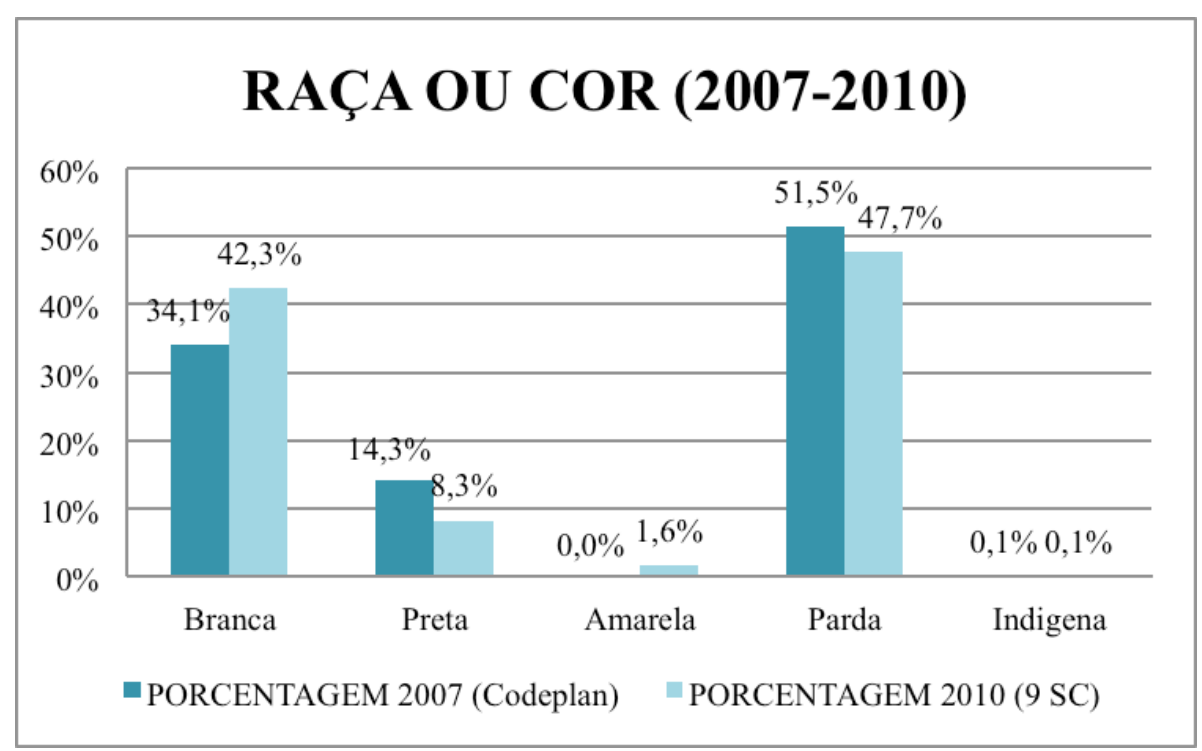

Gráfico 6: Raça ou cor declarada na Vila Planalto.

Fonte: Censo IBGE 2010, CODEPLAN 2009. 
O Censo de 2000 não considerou a declaração de raça ou cor, contudo, em 2007, a Codeplan fez um levantamento socioeconômico (publicado em 2009) que considerou essa variável. O gráfico 6 mostra a variação entre 2007 e 2010 da porcentagem de moradores segundo sua raça ou cor, considerando apenas o interior da Vila Planalto. Os números são mais expressivos que na comparação anterior, podendo indicar um "branqueamento" dos moradores ou o deslocamento da população negra. Entre 2007 e 2010 os moradores identificados como brancos aumentam de $34,1 \%$ para $42,3 \%$. Na contramão, moradores identificados como negros ou pretos caem de $14,3 \%$ para $8,3 \%$, da mesma forma que os pardos, que diminuem de 51,5\% em 2007 para 47,7\% em 2010.

$\mathrm{Na}$ figura 22 se apresenta a distribuição espacial da população segundo raça ou cor (Censo 2010) nos acampamentos e no entorno da Vila Planalto. Se observa um contraste na composição racial entre os condomínios à beira do lago (SCEN e SHTN) e os acampamentos da Vila, com a exceção do acampamento Tamboril.

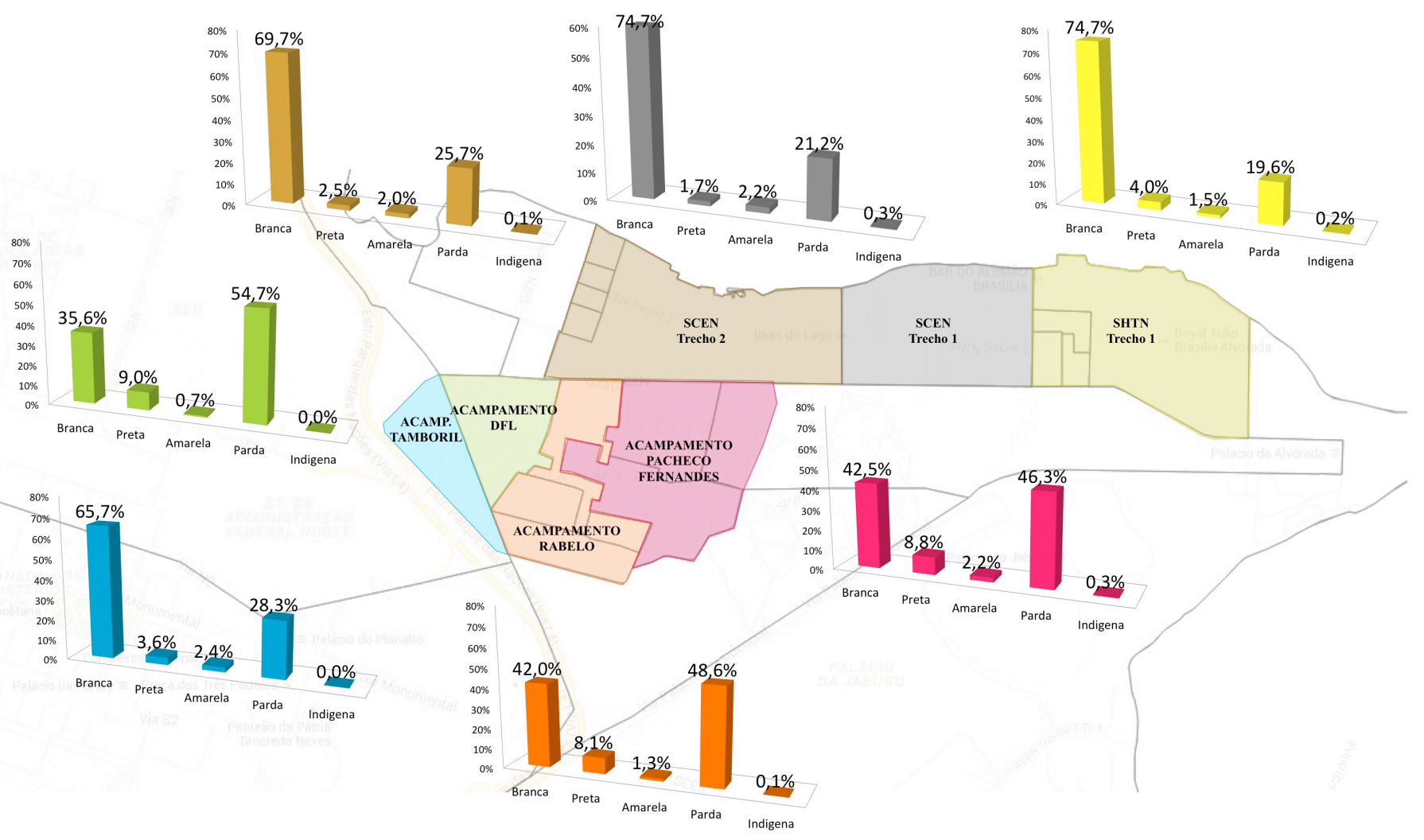

Figura 22: Mapa da distribuição da população segundo raça ou cor na Vila Planalto e entorno.

Fonte: Elaboração própria, com base no Censo IBGE 2010. 
A história da legislação da Vila Planalto é intensa. A pesar de estar por 32 anos desde 1956 até 1988 - como um assentamento provisório e informal em condições de ambiguidade jurídica, desde o tombamento e a fixação foram decretadas quase 40 leis que fazem relação direta com o bairro. Entre 1988 e 2014 foram apresentados 26 projetos de lei na Câmara Legislativa do DF, aprovados 39 leis e decretos, e só desde o ano 2000 se registram 25 processos judiciais relacionados a questões fundiárias. O Quadro 4 apresenta um resumo com a lista cronológica da legislação mais importante em relação à Vila Planalto.

Quadro 4: Resumo da legislação referente à Vila Planalto.

\begin{tabular}{|c|c|c|c|c|}
\hline $\mathbf{N}^{\mathbf{o}}$ & Legislação & Data & Descrição & Características gerais \\
\hline 1 & $\begin{array}{l}\text { Decreto } \\
11.079\end{array}$ & $21 / 04 / 1988$ & $\begin{array}{lrr}\text { Dispõe } & \text { sobre } & \text { o } \\
\text { tombamento } & \text { da } & \text { Vila } \\
\text { Planalto. } & & \\
& & \end{array}$ & $\begin{array}{l}\text { Decreta o conjunto Vila Planalto como patrimônio histórico do } \\
\text { DF. Destacando o caráter peculiar e bucólico. Devendo ser } \\
\text { preservadas: a mimetização com a paisagem, a área de tutela } \\
\text { non aedificandi, o traçado urbano original, identidade, } \\
\text { linguagem arquitetônica e os espaços de valor simbólico. } \\
\text { Considera crime a destruição, mutilação e alteração dessas } \\
\text { características. }\end{array}$ \\
\hline 2 & $\begin{array}{l}\text { Decreto } \quad \mathrm{N}^{\mathrm{o}} \\
11.080\end{array}$ & $21 / 04 / 1988$ & $\begin{array}{l}\text { Dispõe sobre critérios de } \\
\text { fixação da Vila Planalto }\end{array}$ & $\begin{array}{l}\text { Decreta a fixação da Vila Planalto, considerando a preservação } \\
\text { física e social. Destacando a importância da luta dos moradores } \\
\text { por preservar seu espaço de residência. Os critérios são: 1) ter } \\
\text { domicilio há } 5 \text { anos; 2) Estar no levantamento socioeconômico } \\
\text { de } 1986 \text { (SHIS); 3) Não ser cessionário, proprietário ou } \\
\text { proeminente comprador de outra residência no DF. Cria o } \\
\text { GEAP para implementar o processo. }\end{array}$ \\
\hline 3 & $\begin{array}{l}\text { Decreto } \mathrm{n}^{\mathrm{o}} \\
12.246\end{array}$ & $05 / 03 / 1990$ & $\begin{array}{l}\text { Dispõe sobre material de } \\
\text { construção a ser } \\
\text { empregado no Conjunto da } \\
\text { Vila Planalto }\end{array}$ & $\begin{array}{l}\text { Decreta o uso de madeira nas restaurações, acréscimos ou novas } \\
\text { edificações. Admite uso de alvenaria apenas em áreas úmidas } \\
\text { (não em fachadas aparentes) e na base do muro perimetral (até } \\
30 \mathrm{~cm} \text { de altura). }\end{array}$ \\
\hline 4 & $\begin{array}{l}\text { Decreto } \mathrm{n}^{\mathrm{o}} \\
12.247\end{array}$ & $05 / 03 / 1990$ & $\begin{array}{l}\text { Aprova o regulamento para } \\
\text { a regularização das } \\
\text { unidades imobiliárias do } \\
\text { conjunto da Vila Planalto. }\end{array}$ & $\begin{array}{l}\text { Regulamento: 1) Morador cadastrado pela SHIS (1986/87) deve } \\
\text { residir por } 5 \text { anos, mínimo. 2) Documento comprobatório } \\
\text { fornecido pela TERRACAP, CEB, ou CAESB. 3) Cabe a GEAP } \\
\text { a aprovação. 4) Regularização imobiliária por Contrato de } \\
\text { Concessão de Uso de } 25 \text { anos prorrogável. 5) Pagamento de } \\
\text { Taxa de ocupação ( } 50 \% \text { desconto para renda familiar menor o } \\
\text { igual a } 3 \mathrm{SM} \text { ). 6) Cumprimento das NGB. }\end{array}$ \\
\hline 5 & $\begin{array}{l}\text { Decreto } \\
13.184\end{array}$ & $15 / 05 / 1991$ & $\begin{array}{l}\text { Altera o inciso } \mathrm{I} \text { do } \\
\text { parágrafo único do artigo } \\
1^{\circ} \text { do Decreto } \mathrm{N}^{\circ} 12.246\end{array}$ & $\begin{array}{l}\text { Altera o material de construção a ser empregado no conjunto da } \\
\text { vila planalto. Permitindo uso de alvenaria nas áreas internas das } \\
\text { unidades habitacionais, desde que não se localizem nas fachadas } \\
\text { aparentes. }\end{array}$ \\
\hline 6 & $\begin{array}{l}\text { Decreto } \\
13.751\end{array}$ & $29 / 01 / 1992$ & $\begin{array}{l}\text { Dispõe sobre a necessidade } \\
\text { de uniformizar os critérios } \\
\text { de habilitação de } \\
\text { candidatos à moradia no } \\
\text { DF }\end{array}$ & $\begin{array}{l}\text { Decreta a adoção das normas do Regulamento do Decreto } \mathrm{n}^{\circ} \\
10.056 \text { e começam a reger para o processo de fixação da Vila } \\
\text { Planalto. Permite que proprietários de outras unidades } \\
\text { imobiliárias possam receber a concessão de uso na Vila. }\end{array}$ \\
\hline
\end{tabular}




\begin{tabular}{|c|c|c|c|c|}
\hline 7 & Lei $\mathrm{n}^{\circ} 271$ & $29 / 05 / 1992$ & $\begin{array}{l}\text { Autoriza } \text { o Poder } \\
\text { Executivo a fixar } \\
\text { moradores pioneiros da } \\
\text { Vila Planalto }\end{array}$ & $\begin{array}{l}\text { Autoriza ao Poder Executivo a fixar os moradores Pioneiros da } \\
\text { Vila Planalto segundo requisitos do decreto } N^{\circ} 11.080 \text {. Incorpora } \\
\text { a fixação } 248 \text { famílias de filhos de pioneiros e moradores que } \\
\text { sempre residiram no local e não foram cadastrados no } \\
\text { levantamento realizado em } 1986 / 87 \text { SHIS. Autor: Fernando } \\
\text { Naves (PPB). }\end{array}$ \\
\hline 8 & $\begin{array}{l}\text { Decreto } \mathrm{n}^{\mathrm{o}} \\
14.663\end{array}$ & $05 / 04 / 1993$ & $\begin{array}{l}\text { Dispõe sobre a extinção do } \\
\text { GEAP }\end{array}$ & $\begin{array}{l}\text { Elimina o GEAP e entrega à Administração Regional de } \\
\text { Brasília (RA-1) a responsabilidade pela Vila Planalto, em } \\
\text { infraestrutura urbana, ações relativas à preservação e } \\
\text { parcelamento urbano. Processos relativos à fixação passam a ser } \\
\text { julgadas pela SHIS. }\end{array}$ \\
\hline 9 & $\begin{array}{l}\text { Decreto } \mathrm{n}^{\circ} \\
16.226\end{array}$ & $28 / 12 / 1994$ & $\begin{array}{l}\text { Aprova o projeto referente } \\
\text { ao conjunto tombado da } \\
\text { Vila Planalto. Memorial } \\
\text { descritivo MDE-90/90, } \\
\text { plantas URB-90/90 e nas } \\
\text { NGB 90/90, 163-164- } \\
\text { 165/90. Segundo princípios } \\
\text { apresentados pelo GT- } \\
\text { Brasília de } 04 / 1987 .\end{array}$ & $\begin{array}{l}\text { Memorial destaca a forma interiorizada e a vegetação } \\
\text { exuberante. A malha urbana se caracteriza pelas diferenças entre } \\
\text { os acampamentos e a estrutura viária tem sua própria } \\
\text { hierarquização. Reconhece uma relação entre o tamanho do } \\
\text { imóvel e o nível de renda. Dinâmica urbana favorecida pela } \\
\text { diversidade de lotes, usos e pela relação direta do espaço } \\
\text { privado com o público. Classifica três categorias: 1) Edificações } \\
\text { de Preservação Rigorosa, 2) Edificações de interesse histórico, } \\
\text { 3) Edificações remanescentes. Determina afastamento mínimo } \\
\text { (1,5m), taxa de máx. de ocupação (30-25\%), no pavimentos (1), } \\
\text { altura }(4,5 \mathrm{~m}) \text {. }\end{array}$ \\
\hline 10 & $\begin{array}{l}\text { Lei } \mathrm{n}^{\mathrm{o}} \\
1.060 / 1996\end{array}$ & $30 / 04 / 1996$ & $\begin{array}{l}\text { Dispõe sobre a concessão } \\
\text { de título de transferência } \\
\text { de posse e domínio pelo } \\
\text { GDF, na Vila Planalto. }\end{array}$ & $\begin{array}{l}\text { Tem direito à aquisição das unidades: 1) moradores cadastrados } \\
\text { pela SHIS em } 1986 \text { e } 1987 \text {; 2) moradores que receberam lotes } \\
\text { por transferência e inclusões, formalizadas GEAP entre } 1989 \text { e } \\
\text { 1994; 3) filhos de pioneiros, de acordo com a Lei no 271/1992; } \\
\text { 4) moradores de } 7 \text { unidades do acampamento EBE. A concessão } \\
\text { será por termo de compromisso de compra e venda, com } \\
\text { cláusula de fixação de prazo de seis anos para construção e de } \\
\text { proibição da transferência do imóvel antes do cumprimento de } \\
\text { todas as obrigações contratuais. Faculta ao beneficiário a } \\
\text { concessão do direito real de uso, com opção pela compra, a } \\
\text { qualquer tempo. Autor: Luiz Estevão (PP/PMDB)) e Marcos } \\
\text { Arruda (PRTB). } \\
\text { Declarada Inconstitucional pelo TJDFT. }\end{array}$ \\
\hline 11 & Lei $\mathrm{n}^{\circ} 1.231$ & $21 / 10 / 1996$ & $\begin{array}{l}\text { Altera normas de } \\
\text { edificação dos lotes que } \\
\text { menciona, situados na Vila } \\
\text { Planalto }\end{array}$ & $\begin{array}{l}\text { As novas NGB valem para os usos residencial-comercial, misto } \\
\text { e institucional. Permite: construção de subsolo, utilização de } \\
\text { materiais metálicos, telhas de cerâmica, cerco de máx. } 2 \mathrm{~m} \text {. de } \\
\text { altura. Autores: Marco Arruda (PRTB) e Luiz Estevão } \\
\text { (PP/PMDB). }\end{array}$ \\
\hline 12 & $\begin{array}{l}\text { Lei } \mathrm{n}^{\circ} \\
1.742 / 1997\end{array}$ & $23 / 10 / 1997$ & $\begin{array}{l}\text { Autoriza a companhia } \\
\text { imobiliária de Brasília } \\
\text { (TERRACAP) a alienar } \\
\text { lotes residenciais em favor } \\
\text { das famílias residentes no } \\
\text { Anexo III do Brasília } \\
\text { Palace Hotel e adjacências. }\end{array}$ & $\begin{array}{l}\text { São beneficiárias famílias participantes da pesquisa } \\
\text { socioeconômica realizada em } 11 / 1995 \text { pelo núcleo da } \\
\text { circunscrição da Vila Planalto em conjunto com a Divisão } \\
\text { Regional de Desenvolvimento Social da Região Administrativa } \\
\text { de Brasília, pelo Instituto de Desenvolvimento Habitacional do } \\
\text { Distrito Federal (IDHAB). Autor: Rodrigo Rollemberg (PSB). }\end{array}$ \\
\hline 13 & $\begin{array}{l}\text { Decreto } \\
19.082\end{array}$ & $11 / 03 / 1998$ & $\begin{array}{l}\text { Aprova Projeto Urbanístico } \\
\text { na RA-I de Brasília }\end{array}$ & $\begin{array}{l}\text { Aprova o projeto urbanístico de parcelamento nas normas 90/90 } \\
\text { de } 1994 \text {. }\end{array}$ \\
\hline 14 & $\begin{array}{l}\text { Lei } \mathrm{n}^{\mathrm{o}} \\
2.384 / 1999\end{array}$ & $09 / 03 / 1999$ & $\begin{array}{l}\text { Cria no GDF a } \\
\text { subministração regional da } \\
\text { Vila Planalto }\end{array}$ & $\begin{array}{l}\text { O Núcleo da Circunscrição Administrativa da Vila Planalto } \\
\text { passa a denominar-se Sub-administração Regional da Vila } \\
\text { Planalto. Autor: Poder Executivo. }\end{array}$ \\
\hline
\end{tabular}




\begin{tabular}{|l|ll|l|l|l|}
\hline 15 & Decreto $\mathrm{n}^{\mathrm{o}}$ & $28 / 10 / 2008$ & $\begin{array}{l}\text { Cria Grupo de Trabalho } \\
\text { para elaborar um plano de } \\
29.652\end{array}$ & $\begin{array}{l}\text { O GT é composto por: SEDUMA-DF (3); Coordenadoria das } \\
\text { aça referente à Vila } \\
\text { Planalto. }\end{array}$ & $\begin{array}{l}\text { Cidades da SEG-DF (1); AGEFIS (1); SEC-DF (1); } \\
\text { Administração Regional de Brasília (1); Subsecretaria de Defesa } \\
\text { do Solo e da Água da SESP-DF; TERRACAP; Companhia de } \\
\text { Saneamento Ambiental do DF; CEB; BRASILIATUR. }\end{array}$ \\
\hline 16 & Lei $\mathrm{n}^{\circ} 5.135$ & $12 / 07 / 2013$ & $\begin{array}{l}\text { Autoriza ao Poder } \\
\text { Executivo de alienar as } \\
\text { unidade imobiliárias na } \\
\text { Vila Planalto }\end{array}$ & $\begin{array}{l}\text { Projeto do GDF que se autoriza a alienar as unidades } \\
\text { imobiliárias localizadas dentro da poligonal de tombamento e } \\
\text { no acampamento EBE. Por doação (para fixados), venda direta, } \\
\text { (para ocupantes) licitação (ocupantes ou outros). }\end{array}$ \\
\hline
\end{tabular}

Entre as principais leis decretadas destacamos três grupos. No primeiro grupo, aspectos fundiários, destacam-se três leis. Primeiro, o decreto de tombamento e fixação de 1988 de autoria do Executivo no mandato de José Aparecido. A segunda lei é a primeira tentativa de transferência da posse dos imóveis de 1996, de autoria de Luiz Estevão e Marcos Arruda, declarada inconstitucional em 2006. A terceira lei corresponde à entrega definitiva das unidades imobiliárias da Vila Planalto, de autoria do Executivo durante mandato de Agnelo Queiroz.

No segundo grupo estão as normativas, que dispõem sobre a legislação urbanística, regulando os materiais, usos, gabaritos, loteamento etc. E no terceiro grupo, aspectos organizacionais, criando comissões para elaborações de planos de intervenção compostas por organizações ligadas ao governo.

No Quadro 5 apresentamos um resumo dos projetos de leis mais importantes, aprovados ou rejeitados, que foram discutidos na CLDF (Câmara Legislativa do Distrito Federal). Observamos diversos projetos de lei que procuraram favorecer a um grupo maior de famílias com a fixação. Outros projetos tentam modificar as normas urbanísticas para, por exemplo, permitir ou legalizar os segundos pavimentos. Por último, encontramos projetos que beneficiariam a grupos pontuais, como igrejas ou associações comunitárias com isenções de impostos ou a entrega de lotes. 
Quadro 5: Resumo dos projetos de leis referentes à Vila Planalto.

\begin{tabular}{|c|c|c|c|c|}
\hline $\mathbf{N}^{\mathbf{0}}$ & Legislação & Data & Descrição & Características gerais \\
\hline 2 & $\begin{array}{ll}\mathrm{PL} & \mathrm{N}^{\mathrm{o}} \\
1.299 / 1994 & \end{array}$ & $15 / 03 / 1994$ & $\begin{array}{l}\text { Institui o direito à escritura definitiva } \\
\text { dos lotes semiurbanizados da Vila } \\
\text { Planalto aos seus legítimos } \\
\text { concessionários. }\end{array}$ & $\begin{array}{l}\text { Autor: Tadeu Roriz (PPB) } \\
\text { Situação: Arquivado }\end{array}$ \\
\hline 3 & $\begin{array}{l}\text { PL } \\
427 / 1995\end{array}$ & $06 / 06 / 1995$ & $\begin{array}{l}\text { Dispõe sobre a concessão de título de } \\
\text { domínio pelo GDF, na Vila Planalto. }\end{array}$ & $\begin{array}{l}\text { Autor: Luiz Estevão (PP/PMDB)* (mandato } \\
\text { cassado em 2000) e Marco Arruda (PRTB). } \\
\text { Situação: Promulgada. }\end{array}$ \\
\hline 5 & $\begin{array}{ll}\mathrm{PL} & \mathrm{N}^{\mathrm{o}} \\
1.776 / 1996 & \end{array}$ & $17 / 06 / 1996$ & $\begin{array}{l}\text { Reserva área para atender filhos de } \\
\text { pioneiros da Vila Planalto. }\end{array}$ & $\begin{array}{l}\text { Autores: Luiz Estevão (PP/PMDB) e Marcos } \\
\text { Arruda (PRTB). } \\
\text { Situação: Arquivado }\end{array}$ \\
\hline 6 & $\begin{array}{ll}\mathrm{PL} & \mathrm{N}^{\mathrm{o}} \\
1.887 / 1996 & \end{array}$ & $01 / 08 / 1996$ & $\begin{array}{l}\text { Dispõe sobre o registro imobiliário } \\
\text { dos lotes da Vila Planalto. }\end{array}$ & $\begin{array}{l}\text { Autor: Tadeu Filippelli (PMDB) } \\
\text { Situação: Arquivado }\end{array}$ \\
\hline 9 & $\begin{array}{l}\text { PLC } \\
650 / 1998\end{array}$ & 1988 & $\begin{array}{l}\text { Permite a construção do segundo } \\
\text { pavimento na Vila Planalto }\end{array}$ & $\begin{array}{l}\text { Autor: Tadeu Filippelli. } \\
\text { Situação: Arquivado. }\end{array}$ \\
\hline 10 & $\begin{array}{l}\text { PLC } \\
411 / 1999\end{array}$ & $02 / 11 / 1999$ & $\begin{array}{l}\text { Determina a destinação de uso } \\
\text { institucional para atividade culto na } \\
\text { Vila Planalto. }\end{array}$ & $\begin{array}{l}\text { Prevê o levantamento e identificação das igrejas } \\
\text { atuando há mais de } 10 \text { ano na Vila Planalto para } \\
\text { ser destinatárias de lotes. Autor: Wasny de Roure. } \\
\text { Situação: Arquivado. }\end{array}$ \\
\hline 11 & $\begin{array}{l}\text { PLC } \\
862 / 2000\end{array}$ & $29 / 11 / 2000$ & Desafeta área pública na Vila Planalto & $\begin{array}{l}\text { Desafetaria área pública de } 3.000 \mathrm{~m} 2 \text { no contorno } \\
\text { da EHTN para construção de posto policial, } \\
\text { destinando o terreno do posto atual }(900 \mathrm{~m} 2) \text { para } \\
\text { atividades de culto. Autor: José Rajão (PMDB) } \\
\text { *(preso em } 2008 \text { por desvio de recursos públicos). } \\
\text { Situação: Vetado. }\end{array}$ \\
\hline
\end{tabular}




\begin{tabular}{|c|c|c|c|c|}
\hline & & & Público (ZHISP) & $\begin{array}{l}\text { aprovada no decreto } \mathrm{N}^{\circ} 16.6226 / 1994 \text {. Entregando } \\
\text { as unidade imobiliárias um contrato de concessão } \\
\text { de direito de superfície de forma gratuita. Autor: } \\
\text { José Edmar (PMDB). Situação: Arquivado. }\end{array}$ \\
\hline 15 & $\mathrm{PLC} \mathrm{N}^{\circ} 2 / 2007$ & $07 / 02 / 2007$ & $\begin{array}{l}\text { Permite a construção do segundo } \\
\text { pavimento na Vila Planalto. }\end{array}$ & $\begin{array}{l}\text { Permitiria construir } 2 \text { pavimentos, aumento a } \\
\text { altura máx. em } 8,5 \mathrm{~m} \text {. Autor: Pedro Passos } \\
(\mathrm{PMDB})^{*} \text { (Condenado por parcelamento irregular } \\
\text { do solo em 2007). Situação: Arquivado. }\end{array}$ \\
\hline 16 & $\begin{array}{ll}\text { PLC } & \mathrm{N}^{\circ} \\
052 / 2012 & \end{array}$ & $24 / 10 / 2012$ & $\begin{array}{l}\text { Projeto de Lei Complementar, tenta } \\
\text { aprovar o PPCUB. }\end{array}$ & $\begin{array}{l}\text { Enviado pelo GDF, mudaria as normas de uso e } \\
\text { ocupação criando na Vila Planalto a UP6 }\end{array}$ \\
\hline 18 & $\begin{array}{ll}\mathrm{PL} & \mathrm{N}^{\mathrm{o}} \\
1.514 / 2013 & \end{array}$ & $04 / 06 / 2013$ & $\begin{array}{l}\text { Designa relator do projeto Deputado } \\
\text { Cristiano Araújo }\end{array}$ & $\begin{array}{l}\text { O Pdte. da Comissão de Assuntos Fundiários, } \\
\text { Deputado Cristiano Araújo (PTB)* (condenado } \\
\text { por abuso de poder econômico em 2006), se } \\
\text { autodesigna relator do Projeto de Lei. }\end{array}$ \\
\hline
\end{tabular}

Um aspecto a ressaltar da legislação da Vila Planalto são os nomes dos políticos autores dos projetos de lei. Alguns grupos de deputados distritais se repetem durante a história do bairro apresentando diversos projetos de lei. Entre eles estão, Cristiano Araujo, Roney Nemer, Pedro Passos, Luiz Estevão, Marcos Arruda e José Rajão, para nomear apenas os deputados que têm sido condenados por algum crime de improbidade.

Quadro 6: Resumo dos processos jurídicos referentes à Vila Planalto.

\begin{tabular}{|c|c|c|c|c|}
\hline $\mathbf{N}^{\mathbf{0}}$ & Acórdão & Data & Descrição & Características gerais \\
\hline 1 & $\begin{array}{l}\text { Acórdão } \mathrm{N}^{\circ} \\
127170\end{array}$ & $27 / 04 / 2000$ & $\begin{array}{l}\text { Apelação cível. A TERRACAP } \\
\text { ajuizou morador de Vila pedindo a } \\
\text { demolição de muro de alvenaria em } \\
\text { desacordo com a normativa }\end{array}$ & $\begin{array}{l}\text { Resolve que a empresa carece de legitimidade para } \\
\text { ação demolitória já que sua competência se restringe } \\
\text { às concessões de uso, com qual não há } \\
\text { descumprimento. (casa1, Rua dos Engenheiro, Ac. } \\
\text { Pacheco Fernandes). }\end{array}$ \\
\hline 2 & $\begin{array}{ll}\text { Acórdão } & \mathrm{N}^{0} \\
216834 & \end{array}$ & $04 / 04 / 2005$ & $\begin{array}{l}\text { Apelação Cível e Remessa de } \\
\text { Ofício. GDF apela contra ocupantes } \\
\text { do Setor de Chácaras. Apelados } \\
\text { alegam morar há } 42 \text { anos no local } \\
\text { sendo notificados para demolir suas } \\
\text { casas. }\end{array}$ & $\begin{array}{l}\text { Parcialmente provido. Concede-se a proteção } \\
\text { possessiva em favor dos imóveis já edificados e não } \\
\text { das obras em construção. Justiça reconhece } \\
\text { jurisprudência que tolera construções em áreas } \\
\text { publicas por falta de fiscalização. Declara que terras } \\
\text { propriedade da TERRACAP são bens dominicais e } \\
\text { não publicas, podendo ser desafetadas. }\end{array}$ \\
\hline 3 & $\begin{array}{l}\text { Acórdão } \mathrm{N}^{\circ} \\
221296\end{array}$ & $19 / 05 / 2005$ & $\begin{array}{l}\text { Apelação Cível. Processo anulatório } \\
\text { de ato administrativo de } \\
\text { reintegração de posso. }\end{array}$ & $\begin{array}{l}\text { Apelo improvido para pedido de reintegração de } \\
\text { posse da TERRACAP contra residente do Ac. } \\
\text { Rabelo (desde 1974). O decreto } \mathrm{N}^{\circ} 11.080 \text { que } \\
\text { estabelecia que um dos requisitos para a fixação dos }\end{array}$ \\
\hline
\end{tabular}




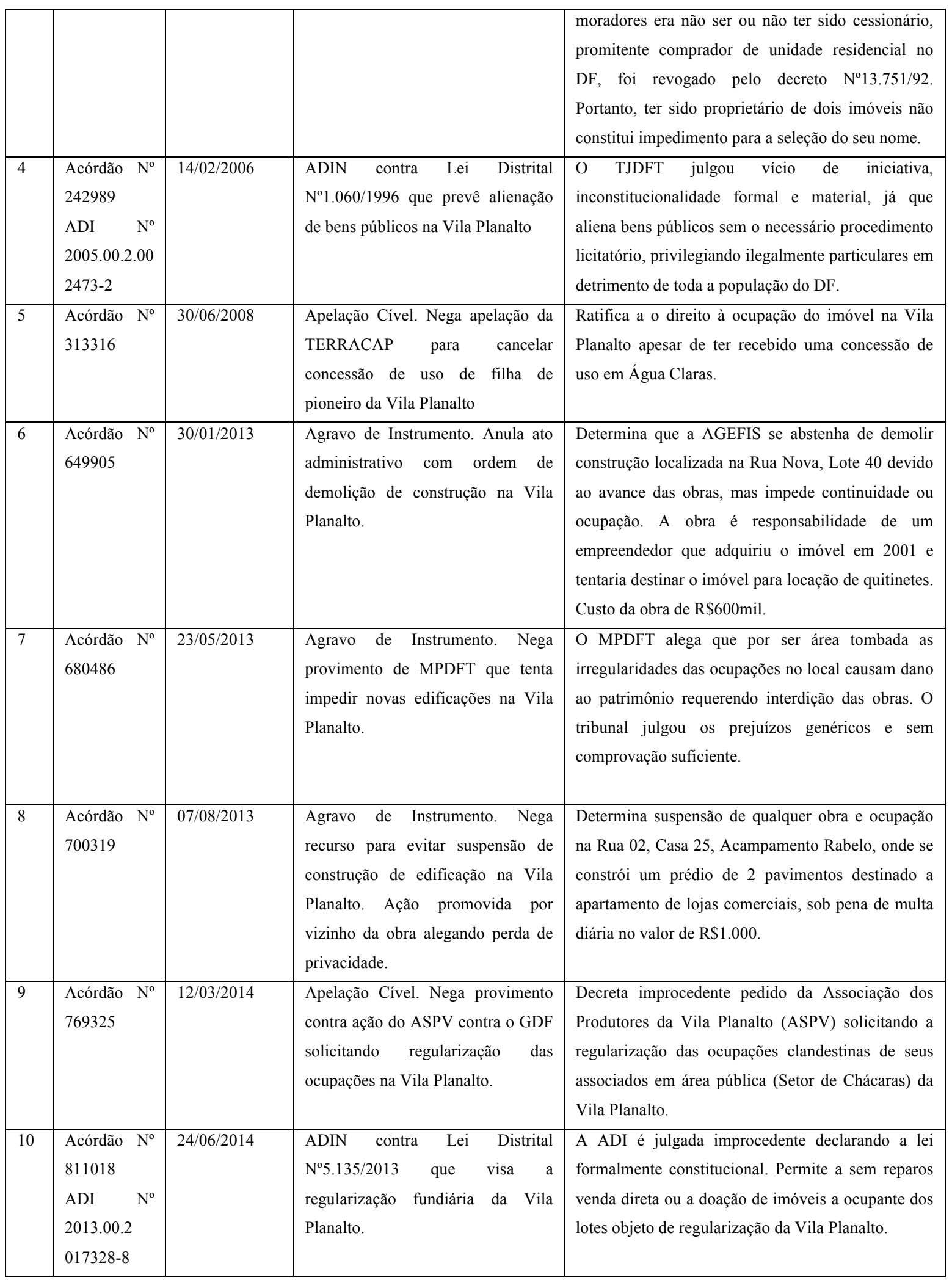

Dos 25 casos levantados do arquivo do TJDFT, entre 2000 e 2014, selecionamos 10 como os mais relevantes. A maioria dos processos corresponde a conflitos fundiários, entre particulares ou entre particulares e o poder público. Uma parte dos processos corresponde às tentativas da TERRACAP de recuperar lotes ocupados com a concessão de uso vencida. Na maioria dos casos a Justiça favoreceu os ocupantes dos 
lotes reconhecendo o legítimo direito de ocupação do imóvel. Outra parte corresponde a duas Ações Diretas de Inconstitucionalidade (ADI) promovidas pelo Ministério Público, a primeira de 1996 contra a lei que entregava os lotes, julgada em 2006 como inconstitucional, e uma segunda ADI de 2013 contra uma nova lei de regularização fundiária, desta vez julgada improcedente.

Resumindo, os quatro períodos históricos selecionados estão fortemente determinados pelas políticas públicas implementadas no local. O primeiro período é de auge e desmantelamento dos acampamentos, entre 1956 e 1964. O segundo período começa com o golpe militar e atravessa longos anos de resistência contras as remoções, até o reconhecimento como patrimônio histórico em 1988. Esse período pode ser entendido como uma primeira fase do processo de gentrificação clássico, uma etapa de aparente abandono e de estigmatizacão. O terceiro período começa com a permanência do bairro em 1988 até 2010. A partir da fixação se inicia uma segunda etapa da gentrificação, fase de especulação que resultou em notável encarecimento das propriedades e do custo de vida. A partir do quarto período, desde 2010, é possível observar o aumento no comércio de bares, restaurantes e lojas, transformando alguns espaços do bairro em lugares de consumo. Esse período corresponde a uma terceira etapa da gentrificação, com a comercialização do espaço e a expulsão dos moradores originais mais pobres (expulsão que começa com a entrega das concessões de uso em 1992, mas se intensifica quando as propriedades alcançam os maiores valores, possivelmente, desde 2008 até hoje). Com a entrega das primeiras escrituras dos imóveis em 2014 é previsível uma nova etapa no processo de gentrificação, onde a regularização fundiária valorize ainda mais o valor do solo e modifique as normas edilícias, perdendo-se o que restou do patrimônio arquitetônico, urbano e social. 


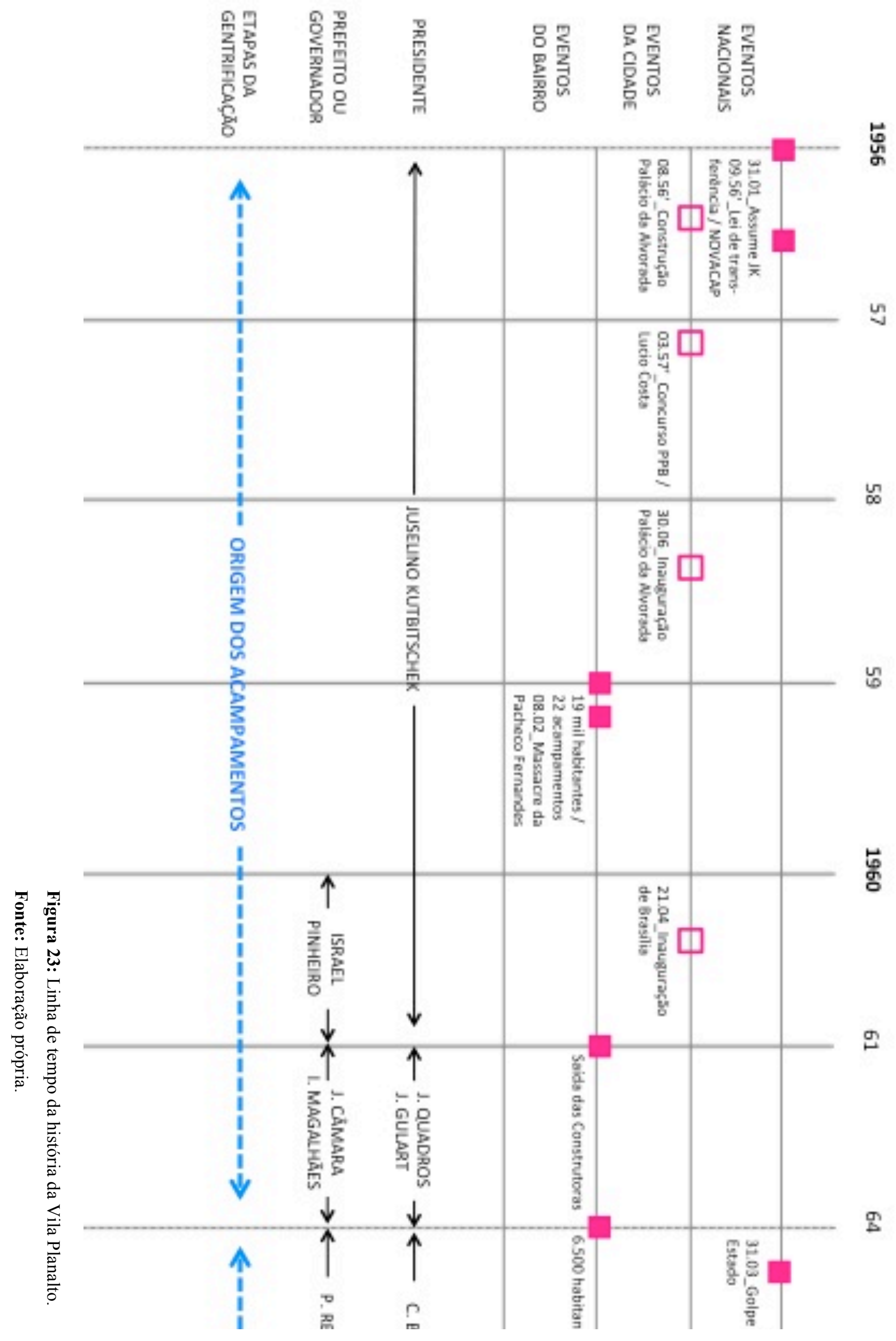




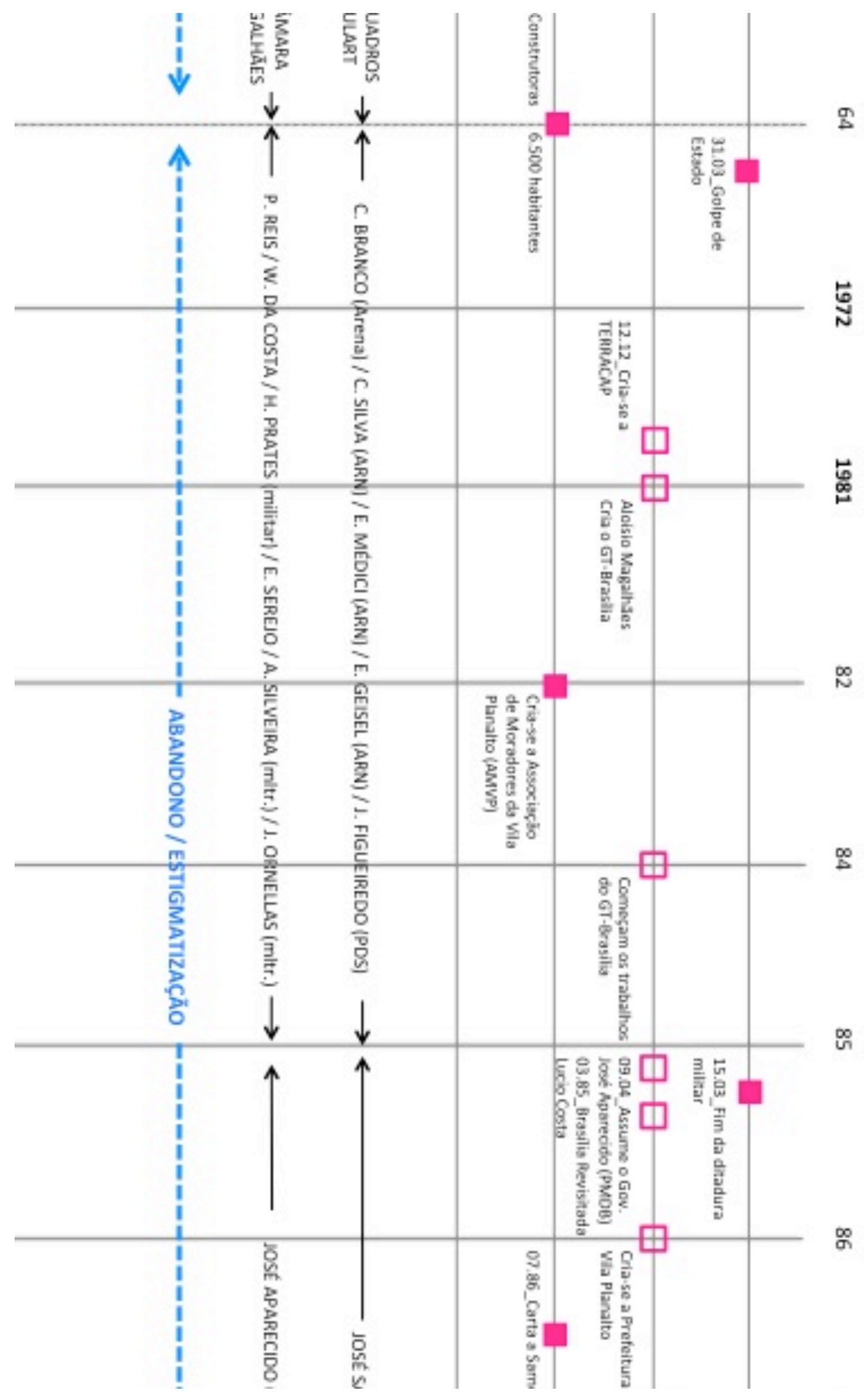




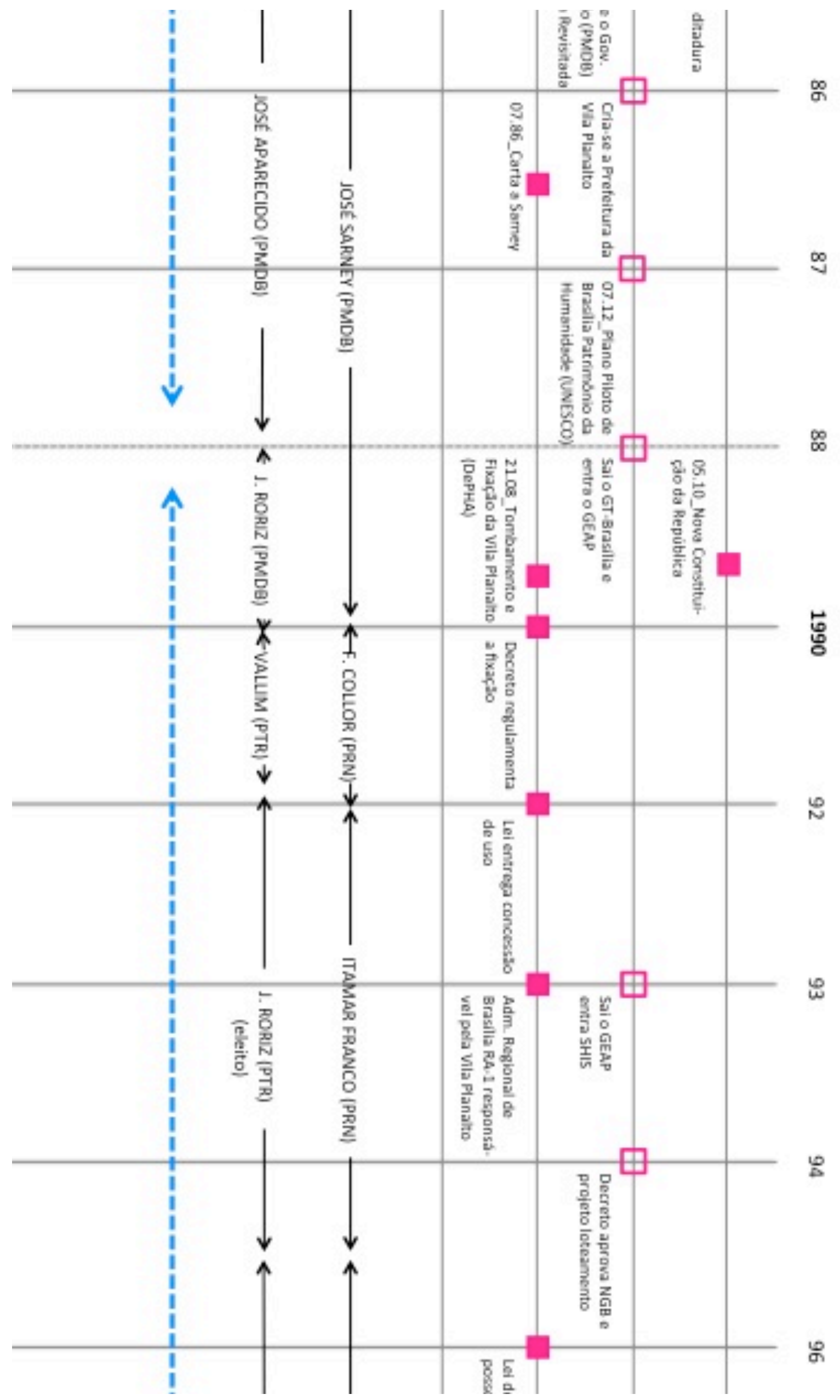




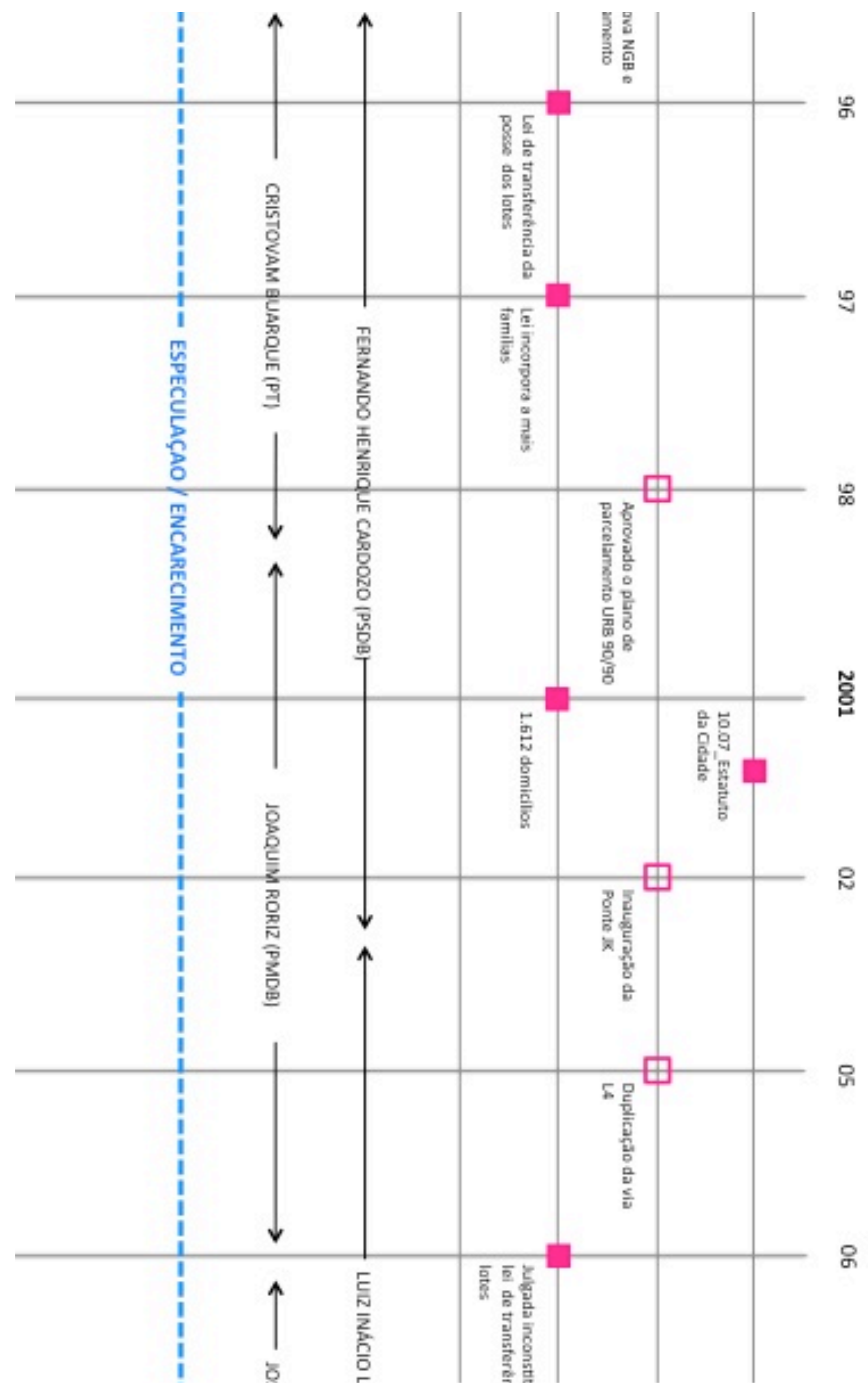




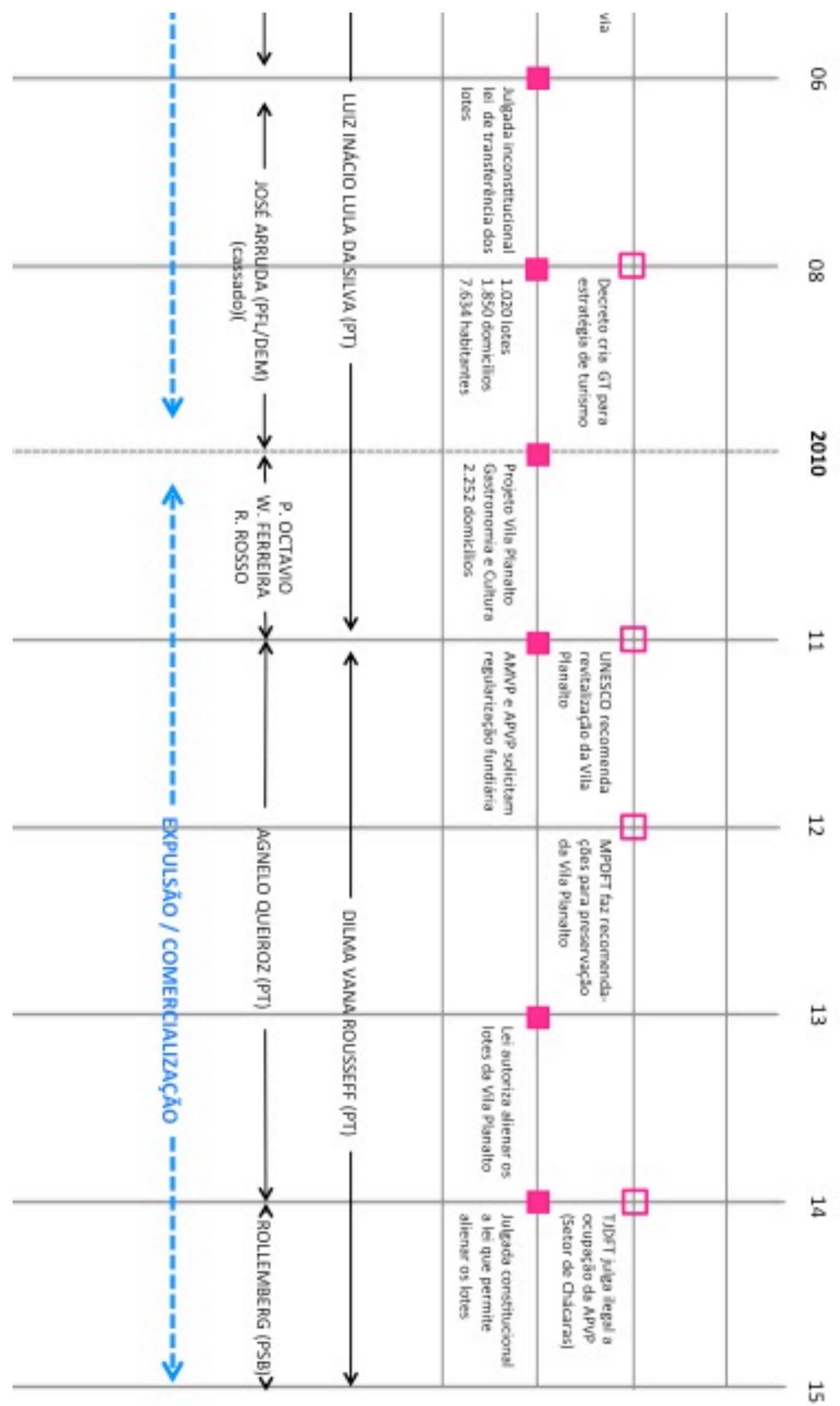




\section{ASPECTOS CONFIGURACIONAIS}

\section{Transformações espaciais}

Esta parte da dissertação analisa as mudanças físicas ocorridas na estrutura espacial da Vila Planalto. Os resultados apresentados derivam da análise sintática do espaço e da utilização do mapa axial. As transformações da configuração espacial ao longo dos anos são relacionadas com as etapas históricas descritas anteriormente. Por causa da falta de informações não foi possível estabelecer o mapa dos acampamentos originais, por isso, a análise configuracional começa a partir do segundo período histórico, com o primeiro mapa de 1965.

$\mathrm{Na}$ Figura 24 e no Gráfico 7a, que expõem o crescimento da ocupação ou mancha urbana da Vila Planalto desde 1965 a 2012, observa-se como, em 1975, o bairro, que já arrastava uma diminuição da sua área por conta da saída das empresas, chega à sua menor área de ocupação. Depois desse ano, registra-se crescimento e expansão até 2012. Apesar das remoções e da condição de ilegal que durou até o tombamento, a área ocupada cresce até 1997. Os maiores crescimentos se observam entre os mapas de 1975 e 1980, e entre 1986 e 1991. Este último indicaria a chegada de mais famílias e a ocupação de novos espaços como resposta à especulação gerada pela fixação.

$\mathrm{Na}$ Figura 24, observa-se como ao longo dos anos a malha urbana ganha maior complexidade e desde 1975 as áreas de cada acampamento vão tornando-se menos definidas. Depois de 1991, verifica-se o adensamento da área central, a partir da ocupação dos interstícios entre os acampamentos, assim a Vila começa a definir sua forma atual. A maioria dos novos quarteirões e lotes que surgiram nas áreas centrais após o tombamento foram regulados e obedeceram ao plano da normativa URB 90/90 proposto pelo governo. 


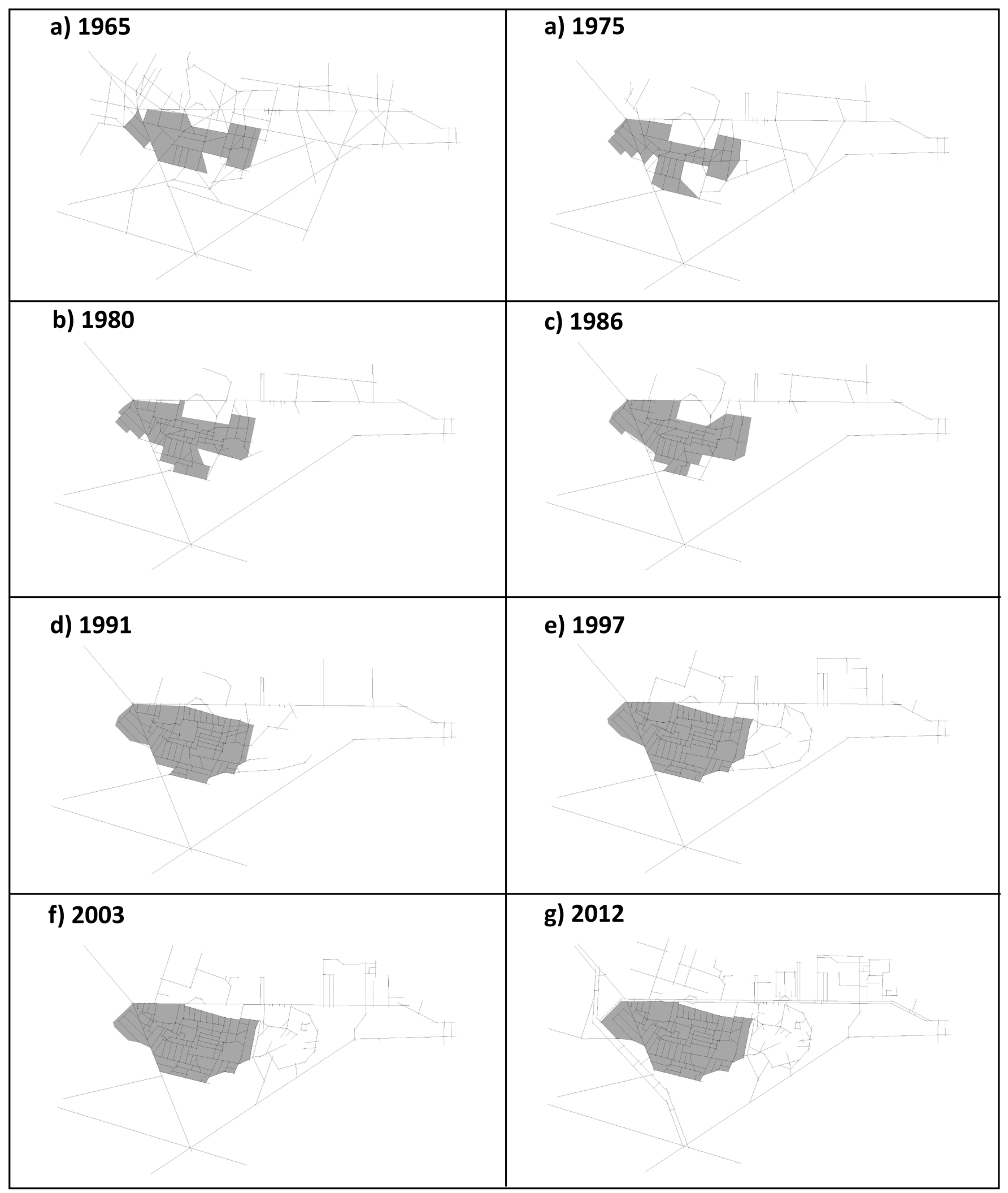

Figura 24: Crescimento da mancha urbana da Vila Planalto.

Fonte: Elaboração própria. 
A medida de Conectividade, indicada no Gráfico $7 \mathrm{~b}$, expressa a quantidade de conexões existentes em um eixo, associando-se à articulação da trama viária com os potenciais de acessibilidade para todos os eixos do mapa. O Gráfico $7 \mathrm{~b}$ mostra como até 1975 a Conectividade média tem a maior queda na quantidade de conexões. Isso se explica porque no início do acampamento existiam vias mais longas e com mais conexões. Mas, com as transformações produzidas pelos habitantes na malha urbana, as ruas ficaram cada vez mais curtas (gerando becos e ruelas), portanto menos conectadas. Ao longo dos anos a malha ganha maior complexidade e desde 1975 as áreas de cada acampamento vão tornando-se menos definidas. Depois de 1991, verifica-se o adensamento da área central, a partir da ocupação dos interstícios entre os acampamentos.

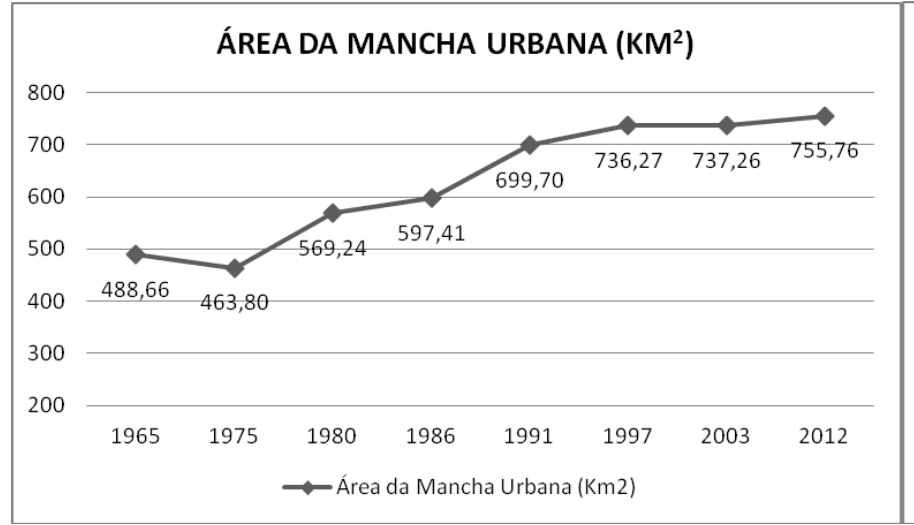

Gráfico 7a: Evolução do tamanho da área da mancha urbana, em $\mathrm{km}^{2}$.

\section{CONECTIVIDADE}

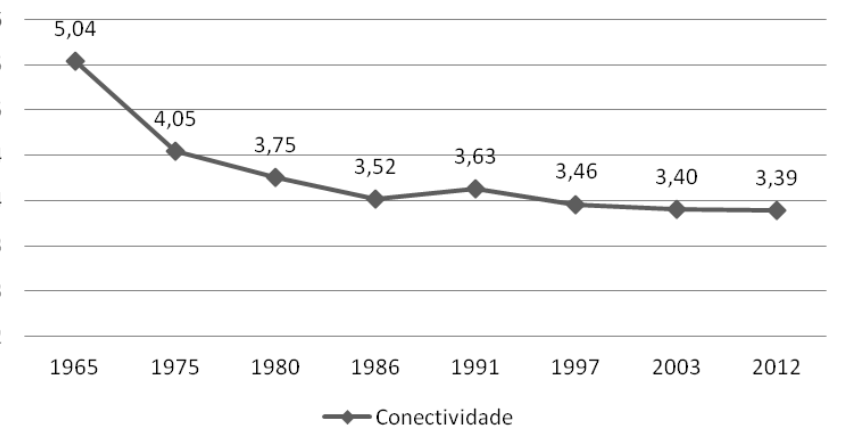

Gráfico 7b: Evolução dos valores médios de Conectividade na Vila Planalto.

Fonte: Elaboração própria.

O comprimento médio (Gráfico 8a), a quantidade de linha por $\mathrm{km}^{2}$ (Gráfico 8b) e a área da mancha urbana (Gráfico 7a), são indicadores de Compacidade. Entendemos a compacidade como a condição de fragmentação ou dispersão da malha urbana. Sistemas mais compactos podem apresentar maior acessibilidade que sistemas mais segregados ou fragmentados.

Como se observa nos gráficos $8 \mathrm{a}$ e $8 \mathrm{~b}$, os valores de comprimento médio e a quantidade de linhas por $\mathrm{km}^{2}$ demonstram que, apesar do tombamento em 1988, as mudanças na malha viária continuaram. O comprimento médio das linhas axiais cai fortemente entre 1965 e 1980, correspondendo ao período em que a vigilância diminuiu e possibilitou a fragmentação das vias internas para o ocultamento das ocupações. Depois do tombamento, nos mapas de $1991 \mathrm{em}$ diante, a quantidade de linhas por $\mathrm{km}^{2}$ 
aumenta, refletindo a expansão e agregação de novas áreas, como o Setor de Chácaras ao final dos anos 2000 .

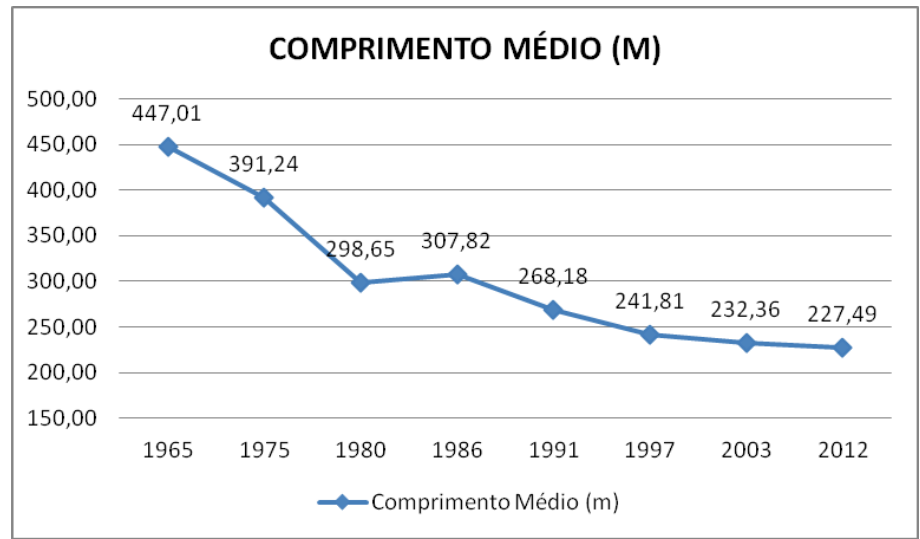

Gráfico 8a: Evolução do Comprimento Médio de Linha em metros.

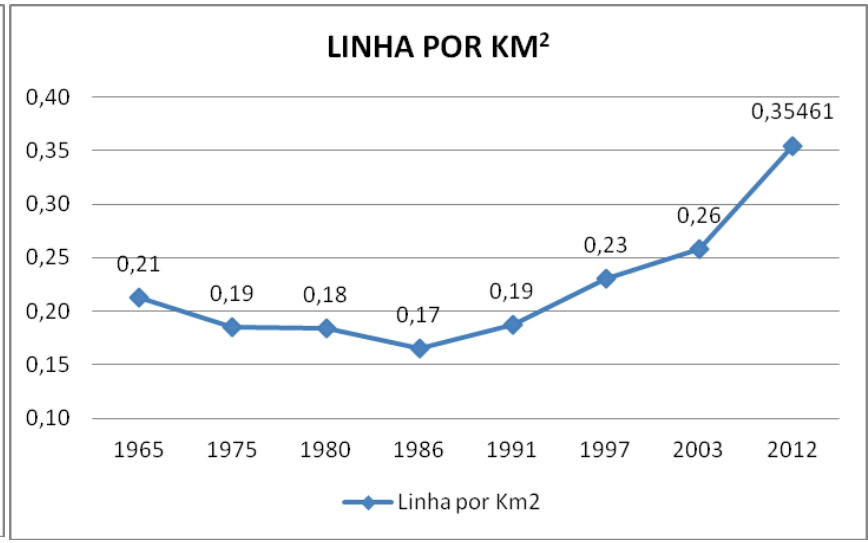

Gráfico 8b: Evolução da Quantidade de Linha por $\mathrm{Km}^{2}$ na Vila Planalto.

Fonte: Elaboração própria.

Em relação à compacidade, a Vila apresenta certo grau de fragmentação nos eixos da malha viária ao longo da história. Essa interpretação se deve ao aumento da quantidade de eixos no sistema, ao mesmo tempo em que esses eixos são progressivamente mais curtos. Essa situação é produzida pelas mudanças no sistema viário e pelos novos eixos e lotes que se unem à malha existente como retalhos, através de pequenas vias que tentavam evitar o controle da fiscalização, a qual não permitia alterar ou construir novas edificações.

A Integração é um dos conceitos mais utilizado em Sintaxe Espacial. A medida de integração ou Integração Global (Rn ou $\mathrm{HH}$ ) descreve o potencial de acessibilidade topológica de cada eixo para todo o sistema, onde " $R$ " é o raio, " $n$ " é o número de conexões e "HH" refere-se a Hillier e Hanson, fundadores da teoria. Os eixos mais integrados, representados com cores mais quentes, são aqueles que representam vias potencialmente mais permeáveis e mais acessíveis no bairro. $\mathrm{O}$ conjunto dos eixos mais integrados (vermelhos) recebe o nome de núcleo de integração.

Por meio dos mapas axiais de integração global (Figura 25), reconhecemos a Estrada de Hotéis e Turismo (EHT) e a via L4 como as mais integradas durante o período estudado. Apesar de não reconhecer um conjunto de linhas mais integradas, a interseção da EHT e a via L4 podem ser consideradas ao longo da história como o núcleo de integração. Essa interseção é o ponto mais accessível de carro para com o resto da cidade. 


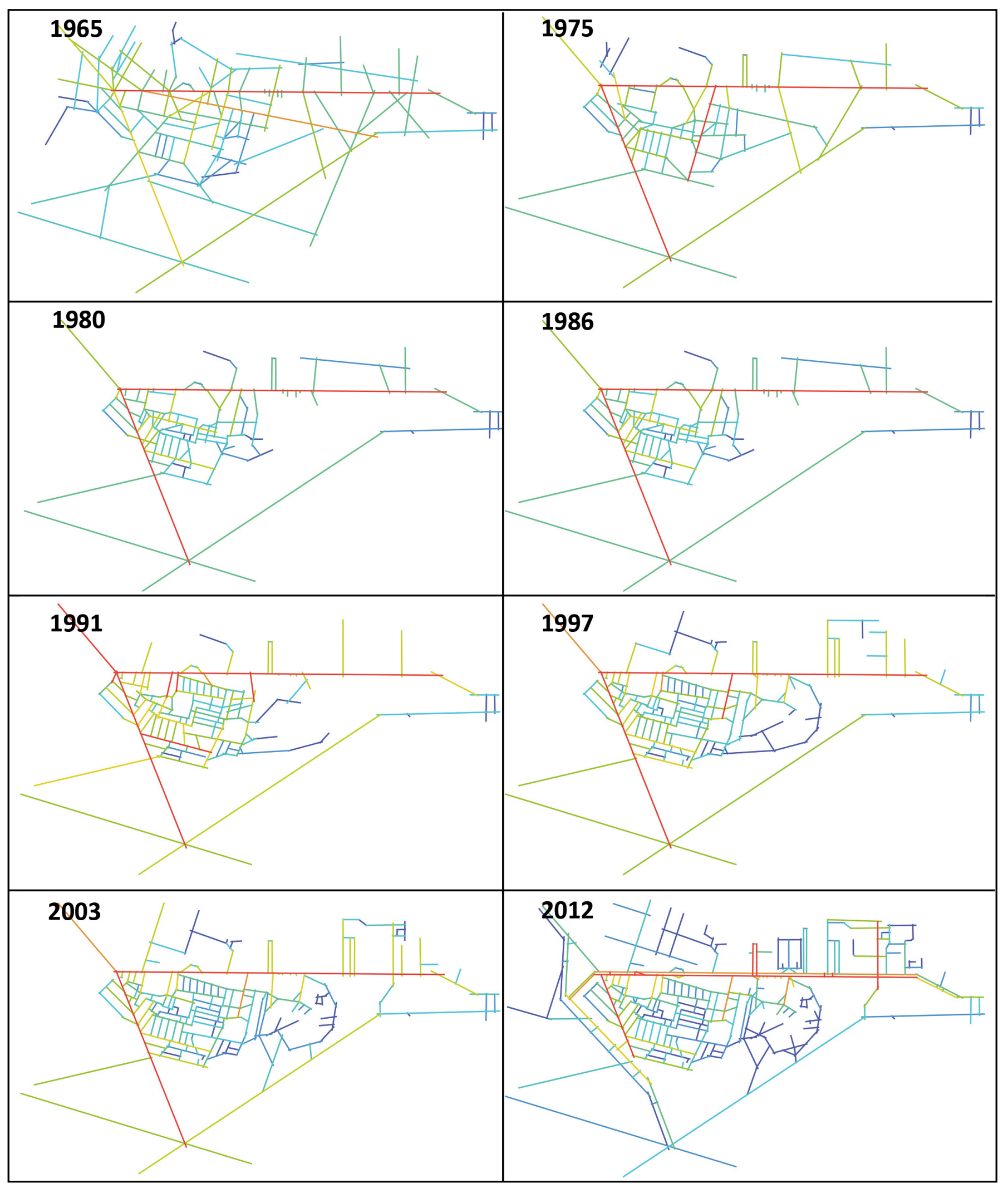

Figura 25: Mapas Axiais históricos mostrando os potenciais de Integração Global Rn.

Fonte: Elaboração própria. 
Com a análise visual dos mapas axiais representados na figura 25, podemos reconhecer os quatro períodos históricos nas transformações da estrutura urbana. O mapa de 1965 demonstra um primeiro momento em que ainda é possível distinguir o sistema como diferentes aglomerações (acampamentos) conectadas por linhas globais que atravessam os acampamentos. Os mapas de 1975, 1980 e 1986 indicam um segundo estágio da forma da malha viária, com a erradicação de acampamentos como a Vila Amauri, e desaparecem vários eixos encontrados no entorno do bairro que provavelmente potenciaram o crescimento interior (adensamento) da Vila. Percebem-se novos eixos no interior do sistema, provocando a descontinuidade das linhas mais longas. Um terceiro momento acontece nos mapas de 1991, 1997 e 2003. Após o tombamento, a forma urbana parece consolidar-se, mas as mudanças não param. Iniciase a gradual aparição de novos eixos na borda do bairro e também dentro da área de tutela (Setor de Chácaras). Um quarto momento se reconhece no mapa de 2012 onde aparece a reforma na L4, que desviou a via por fora do bairro e duplicou a EHT. A transformação mudou o acesso ao bairro (fazendo-o indireto), provocando certo isolamento da Vila. Neste mapa também se reconhece o aparecimento das vias pertencentes aos condôminos à beira do Lago Paranoá.

Com o Gráfico 9a, que apresenta a evolução dos valores médio, máximos e mínimos de Integração Global, é possível observar uma diminuição leve e constante dos valores médios ao longo da história. A diminuição dos valores de integração, que de 2,05 em 1965 passa para 1,26 em 2012, pode ser interpretado como um processo de fragmentação e segregação interna no bairro.

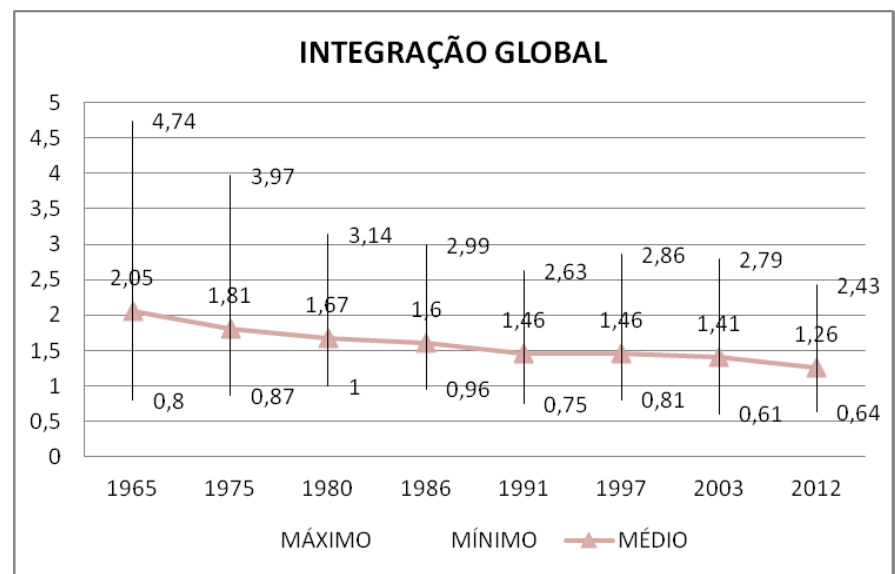

Gráfico 9a: Evolução dos valores potenciais absolutos de Integração Global Rn, na Vila Planalto.

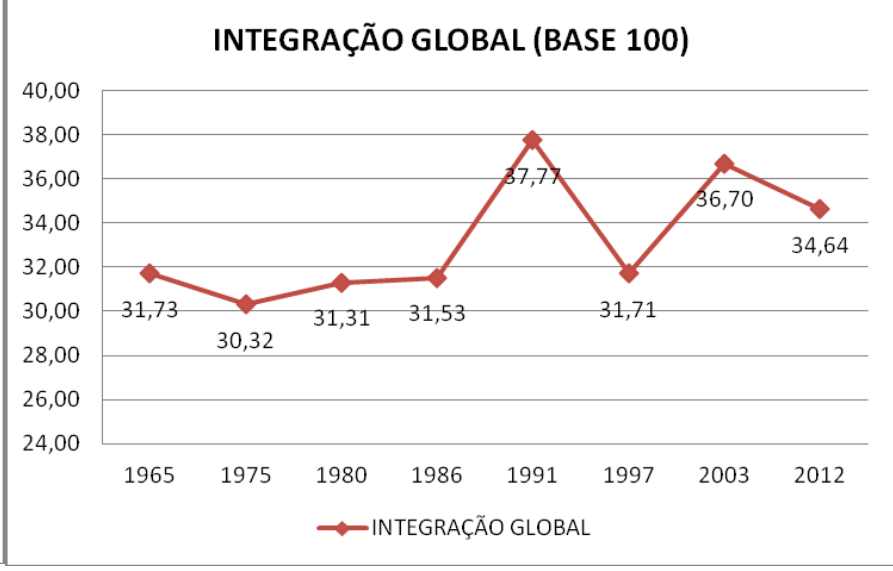

Gráfico 9b: Evolução dos valores médios de Integração Global Rn normalizados para Base 100. Fonte: Elaboração própria. 
O Gráfico $9 \mathrm{~b}$ obedece a outra possibilidade de interpretação dos valores obtidos com os mapas axiais. Para Medeiros (2006) a normalização para uma escala única permite o confronto de dados, já que os polos para todos os mapas serão iguais. Seguindo o autor, foi adotada uma escala de 0 a 100 , onde 0 é o menor valor de integração e 100 é o maior valor. O gráfico aparenta uma inversão dos valores absolutos, quando o valor médio diminui o valor para Base 100 aumenta. Este gráfico acentua as variações ao mostrar a relação entre os polos máximos e mínimos. Um valor de integração máximo alto e uma média mais próxima do mínimo pode indicar que existem poucas linhas com alta integração em contraposição a maior parte dos eixos com integração baixa. A gráfica Base 100 mostra que, entre 1965 e 2012 se conservaram os valores dentro dos 30\%, as maiores variações aconteceram entre 1986 e 2003, o que poderia significar uma etapa de mudanças na malha viária da forma anterior ao tombamento e a transição até a atual estrutura.

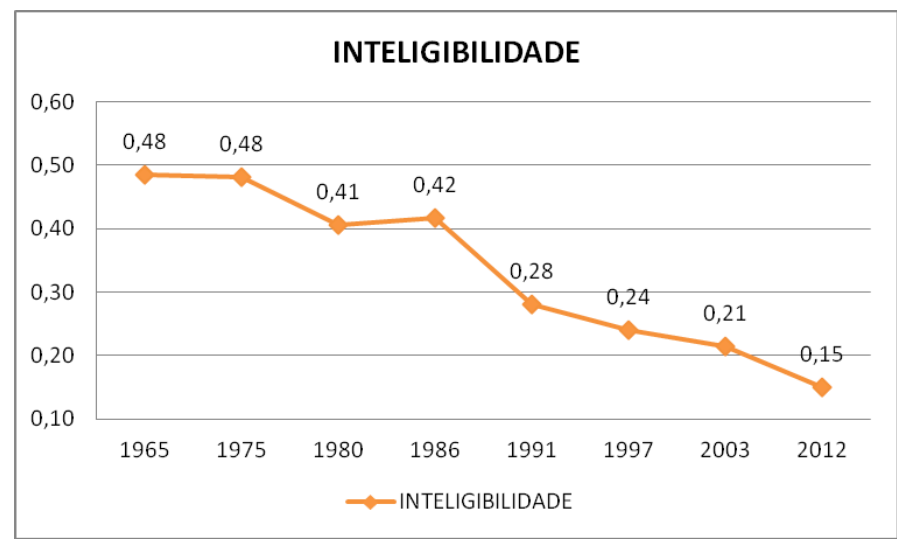

Gráfico 10a: Evolução dos valores de Inteligibilidade.

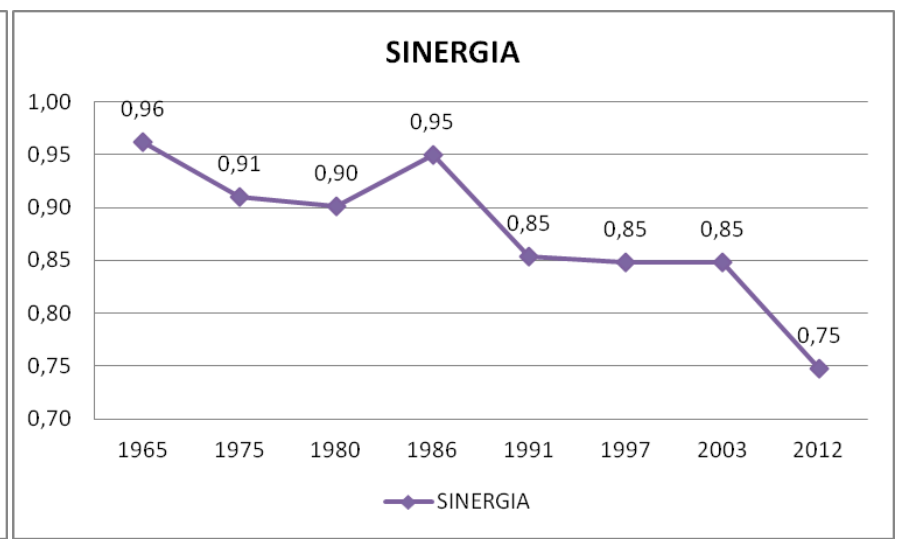

Gráfico 10b: Evolução dos valores de Sinergia. Fonte: Elaboração própria.

$\mathrm{Na}$ Sintaxe Espacial, a medida de Inteligibilidade do mapa axial representa a correlação entre a conectividade e o valor de integração global dos eixos. A medida se expressa como coeficiente de determinação $\left(R^{2}\right)$, ou coeficiente de Pearson (r), que indicam uma associação das variáveis entre si. A Inteligibilidade é interpretada como o potencial de se aprender o sistema como um todo, ou como a facilidade da malha viária para se orientar e localizar nela. Um sistema com poucas linhas globais (que atravessem o sistema completo) pode relacionar-se com uma baixa inteligibilidade. A medida vai de 0 a 1 , quanto mais próximo de 1 maior inteligibilidade. 
A medida de inteligibilidade (Gráfico 10a) na Vila Planalto expressa que a dificuldade de se localizar e orientar no interior do bairro é cada vez mais intensa. Os valores são baixos e se aproximam de forma gradual ao " 0 " ou nula inteligibilidade. Em 1975, o valor estava em 0,48, para chegar a 0,15 em 2012. A diminuição de linhas globais no sistema e a proliferação de vias curtas, menos conectadas, influenciam para que a malha urbana seja menos inteligível com o tempo.

O Gráfico 10b expõe a evolução dos valores de Sinergia, que representam o grau de relação entre os valores de integração global e local. Da mesma forma como a inteligibilidade, a sinergia indica, por meio do coeficiente de determinação, a dependência entre a integração global (Rn) e a integração local (R3). Um valor de sinergia próximo de 1 corresponde a um sistema onde existe uma proporção entre as propriedades das escalas global e local. Como explica MEDEIROS (2006), um sistema grande (com muitos eixos) apresentará uma baixa sinergia em razão da acentuação na diferença de escalas. Um baixo valor de Sinergia pode revelar um espaço labiríntico ou fragmentado, com pouca sincronia entre os eixos globais e locais. Os valores de Sinergia são altos por conta do tamanho reduzido de linhas no sistema. Mas os valores caem de seu valor máximo $(0,96)$ em 1965 para o mínimo $(0,75)$ em 2012. Isso sugere a fragmentação que experimenta a Vila, que se torna labiríntica com o tempo para diminuir o controle do espaço e possibilitar as mudanças das edificações.

O conceito de Controle indica uma posição de dominância de um eixo sobre outros. A medida de controle sugere os eixos topologicamente dominantes de um sistema. Um eixo com valor de controle alto possui grande quantidade de conexões com linhas de baixa conectividade. A variável mede quanto um eixo controla o acesso aos eixos que cruzam com ele. Os eixos com maior controle são representados com cores quentes (linhas vermelhas) e os eixos com menor potencial de controle em cores frias (linhas azuis).

A partir da análise visual da Figura 26, que apresenta os mapas históricos de Controle na Vila Planalto, é possível reconhecer como, no período da origem do bairro, as linhas de maior controle correspondiam aos eixos mais longos que atravessavam o sistema em sua totalidade. Depois das seguidas transformações, em 2012 aparecem linhas vermelhas (dominantes) mais curtas controlando menor quantidade de acessos. 


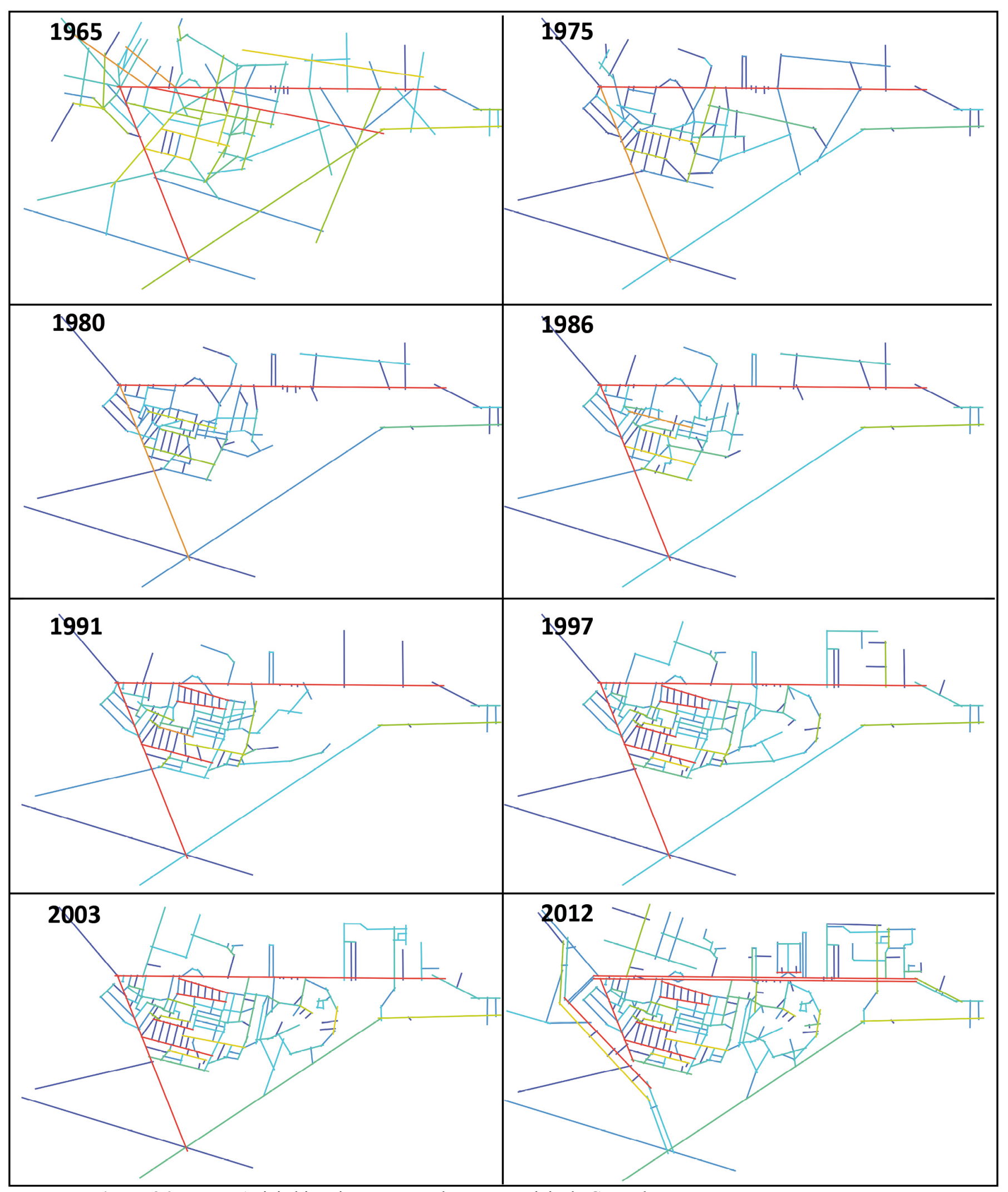

Figura 26: Mapas Axiais históricos mostrando os potenciais de Controle.

Fonte: Elaboração própria. 
O Gráfico 11a mostra os valores máximos, mínimos e médios do Controle espacial. Apesar de que se previa uma diminuição do controle, esta medida se manteve quase constante durante o tempo. Existe uma variação nos valores máximos, mas os valores médios se conservam baixos e afastados dos valores máximos, o que indica a presença de poucas linhas dominantes versus muitas linhas dominadas no sistema.

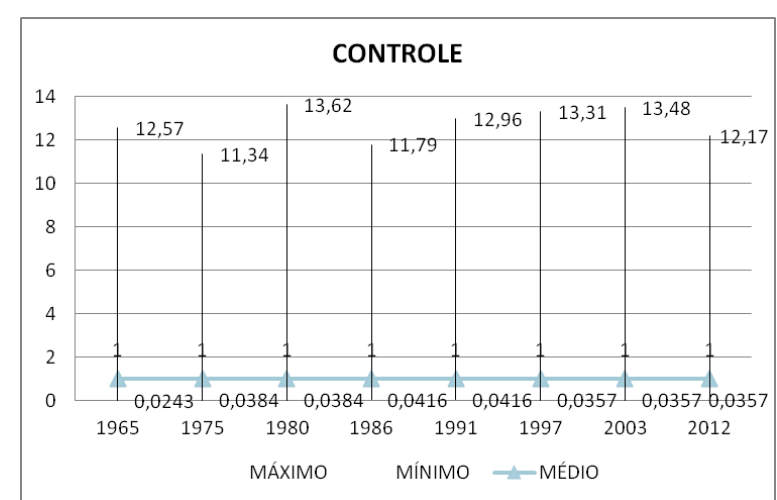

Gráfico 11a: Evolução dos valores mínimos, médios e máximos de Controle.

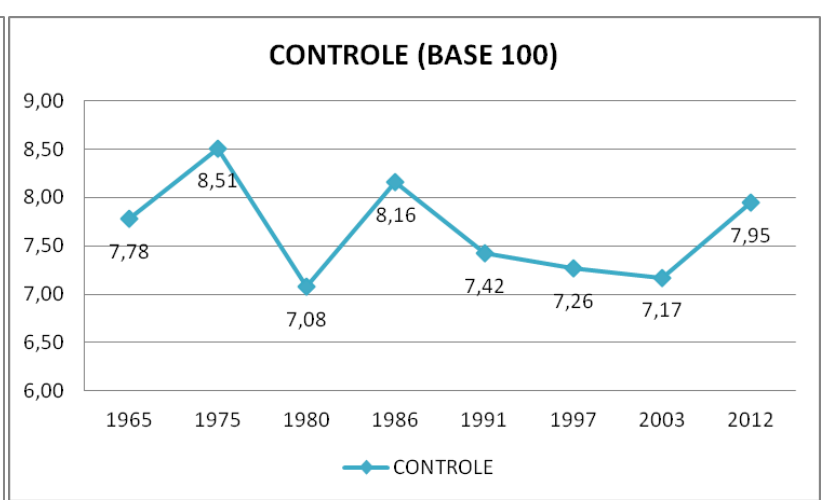

Gráfico 11b: Evolução das médias de Controle, normalizada para Base 100.

Fonte: Elaboração própria.

O Gráfico 11b apresenta os valores médios normalizados para Base 100. Esses valores baixos que flutuam entre 7-8\% explicam-se pela proximidade da média com os valores mínimos, confirmando a influência da maior quantidade de linhas com muito baixo controle. Ainda que se observe uma constante nos valores normalizados de controle nos mapas axiais, parece ocorrer uma diminuição do comprimento das linhas vermelhas ou com potencial de controle (desaparecem as linhas mais longas), com isso as linhas dominantes se tornam mais curtas, controlando, em consequência, uma quantidade menor de eixos. Isso pode ser interpretado como uma perda do controle global do bairro, em razão da descontinuidade ou pouca articulação entre os acampamentos. 


\section{Configuração espacial e dinâmica urbana}

Esta parte apresenta uma seleção dos atuais mapas axiais e de segmentos analisados em diferentes raios de análise no software Depthmap. Para a análise axial foram relevantes as variáveis de Integração, Controle e Escolha. Para a análise de segmentos, avaliaram-se as variáveis de escolha e integração. A principal abordagem é a análise visual dos mapas para identificar os eixos com maior potencial de acessibilidade. O objetivo é visualizar a lógica das possibilidades de movimento de veículos e pedestres ao interior do bairro.

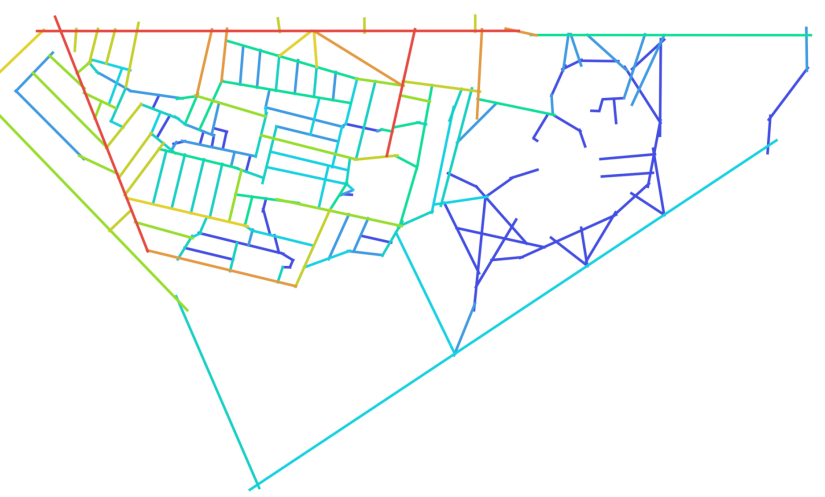

Figura 27a: Mapa axial de Integração Global Rn (HH) na Vila Planalto, 2013.

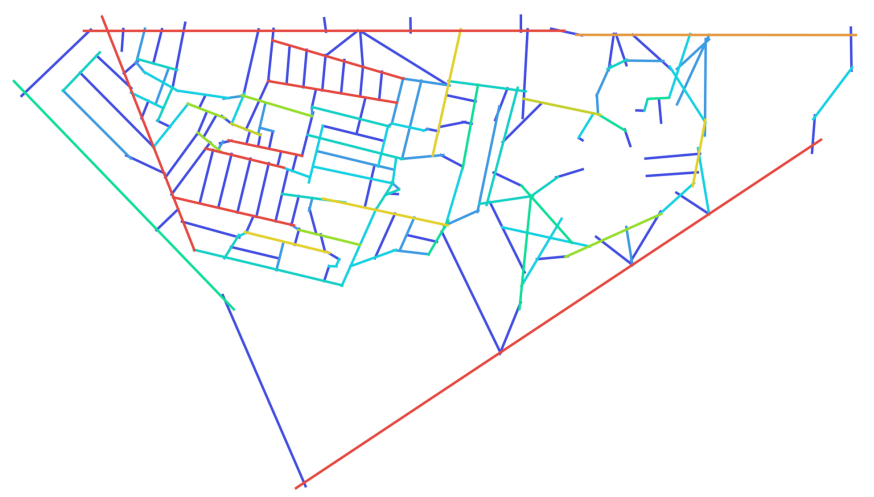

Figura 27b: Mapa axial de Controle, 2013.

Fonte: Elaboração própria.

Observando o mapa axial de Integração (Figura 27a) da atual Vila Planalto, reconhecemos uma malha urbana de forma desigual composta pela união de traçados regulares e irregulares. Diferenciam-se quatro setores ou divisões segundo a forma da malha e seus potenciais de acessibilidade espacial ou integração global e local.

1) Eixos mais extensos localizados no perímetro do sistema, que definem os limites do bairro (polígono de tombamento e tutela). Na Figura 27a sobressaem como as vias mais integradas a EHT e o trecho da via L4 (que passa pelo interior do bairro).

2) Acampamento Tamboril, área composta por poucos eixos, regulares e segregados e pela descontinuidade que - em parte - causa uma das vias mais integradas, o trecho da L4. Os eixos têm uma integração média, mas que conecta diretamente com uma das vias mais acessíveis. 
3) Os acampamentos DFL, Rabelo e Pacheco Fernandes configuram uma unidade espacial resultante da interação de eixos com níveis de integração alta, média e baixa. Predominam áreas de linhas regulares unidas por vias irregulares, como becos e ruelas. O acampamento DFL possui a forma mais irregular e fragmentada, enquanto no Rabelo de Pacheco Fernandes as ruas são mais regulares e ortogonais.

4) O setor de Chácaras agrupa vias quebradas em eixos curtos, configurando uma forma irregular anexada à malha dos acampamentos originais. As vias com mais baixa integração global do sistema apresentam uma estrutura que se ramifica (eixos que se subdividem), voltada para seu interior, conectando com vias mais longas, mas com integradas global baixa e local média.

A Figura 27b mostra o mapa axial de Controle. Como foi dito anteriormente, a medida de controle indica os eixos com uma posição espacial (permeabilidade, movimento, acessibilidade) dominante dentro do sistema. Percebe-se o contraste entre os eixos de maior controle (vermelhos) e os eixos controlados (azuis), são dois setores com traçado regular onde duas linhas axiais são intersectadas por eixos paralelos. Essas áreas em destaque revelam os eixos pertencentes aos acampamentos originais, que conservaram seu traçado e sua estrutura de controle do espaço. Por outro lado, os eixos que unem aos antigos acampamentos têm cores verde e celeste (com exceção do acampamento Tamboril) indicando que potencialmente não dominam nem são controladas por outras vias.

Os mapas de segmentos consistem em transformar o mapa axial em trechos de vias determinadas por todas as interseções que existem. Um mapa de segmentos oferece resultado mais refinado quanto ao potencial de acessibilidade e escolha em uma via, permitindo reconhecer as diferenças de acessibilidade para partes menores dos eixos. Os segmentos detalham os potenciais de fluxos de movimentos em setores específicos de cada via.

$\mathrm{Na}$ análise de segmento, a integração é calculada pelo grau com que uma linha está mais próxima em relação a todos os segmentos do sistema, considerando o menor caminho angular, ou seja, com a menor quantidade de mudanças de direção. Chiaradia et al. (2009) comentam que a medida corresponde a quão acessível é cada segmento em relação a todos os outros do sistema, e quanto potencial tem de ser destino do movimento de pessoas. 
As figuras $28 \mathrm{a}$ e $28 \mathrm{~b}$ exibem os mapas de segmentos indicando os potenciais de Integração para os raios n, e 400m. A figura 28a não apresenta diferenças relevantes em relação ao mapa axial. A figura $28 \mathrm{~b}$ analisa a integração para um raio de $400 \mathrm{~m}$ (aproximadamente 5 minutos a pé), o mapa que esboça uma centralidade interna do bairro. Os segmentos mais integrados se agrupam ao redor dos vazios, principalmente da Praça da Rabelo. Esses segmentos indicam os potencias caminhos mais intensamente utilizados pelos pedestres e conformam possíveis rotas que ligam as residências com o comércio local localizado no miolo dos acampamentos e com as vias globais mais integradas localizadas no perímetro do bairro (figura 28a).

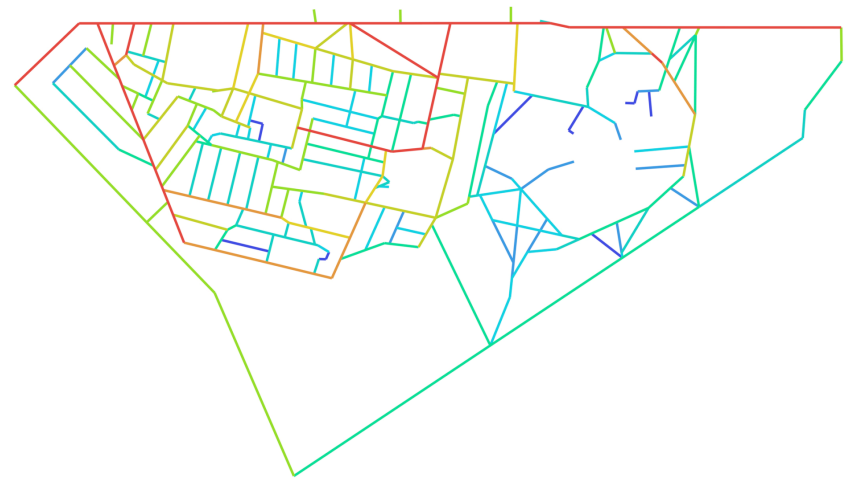

Figura 28a: Mapa de Segmentos, Integração Rn.

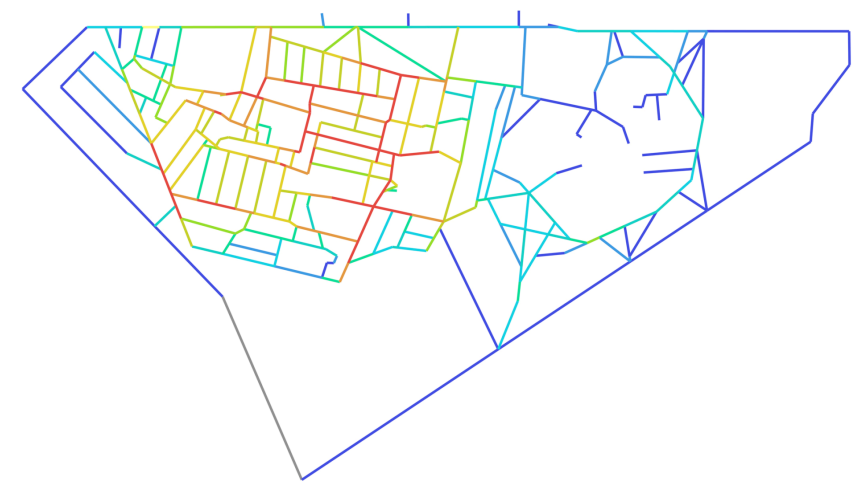

Figura 28b: Mapa de Segmentos, Integração R400m. Fonte: Elaboração própria.

Segundo Hillier (2007), a variável de escolha, processada como análise de segmentos no software Depthmap, demonstra maior correlação com o modo segundo o qual as pessoas andam pelo espaço. A Escolha é uma variável que revela os fluxos através do espaço. A medida de escolha é associada pelo autor como o potencial de todos os eixos ou segmentos para proporcionar as rotas mais prováveis de utilização nos fluxos de circulação (HILLIER, 2007). O valor da variável mede o número de vezes que uma via se repete como possível caminho de circulação em um determinado raio de análise. $\mathrm{Na}$ análise sintática percebe-se que a escolha está relacionada com padrões de movimento de veículos e pedestres para todos os segmentos (RODRIGUEZ et al., 2012).

As Figuras 29a e 29b exibem os mapas de segmentos para análise de escolha nos raios $n$, e $400 \mathrm{~m}$. Da mesma forma que os mapas anteriores, a análise para o raio $n$ não se 
diferencia dos resultados do mapa axial, e as linhas com maior potencial de escolha estão dispersas sem conformar um conjunto. A análise para o raio de 400m (Figura 29b) destaca agrupações de segmentos com alto potencial de escolha no interior do bairro. Para o raio de $400 \mathrm{~m}$, os segmentos com maior potencial de escolha se agrupam ao redor da Praça da Rabelo e parece avançar para a L4 (via com maior potencial de escolha no raio $n$ ). os segmentos mais vermelhos ampliam-se, indicando potenciais caminhos entre os espaços públicos com maior presença de pessoas do bairro: a Praça Rabelo e a Praça Nelson Corso. Também é possível reconhecer rotas ou caminhos que unem esses vazios com a L4, no segmento onde se encontra um dos acessos ao bairro e um ponto de ônibus intensamente utilizado.

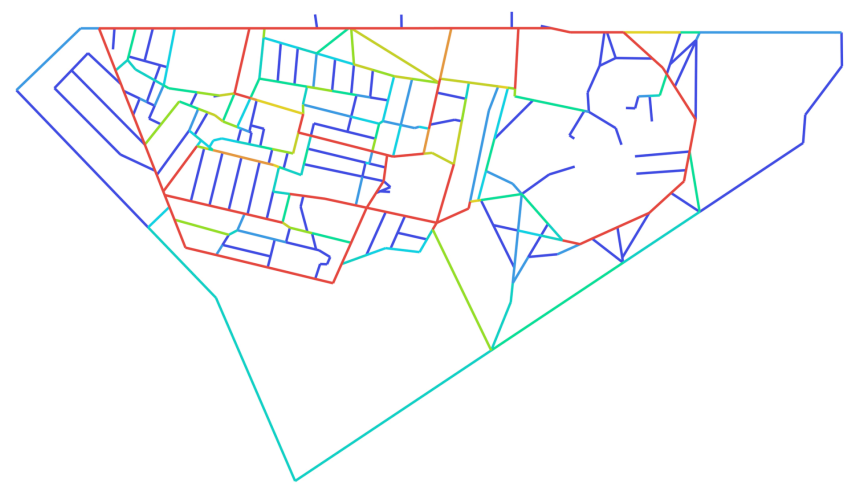

Figura 29a: Mapa de Segmentos, Escolha Rn.

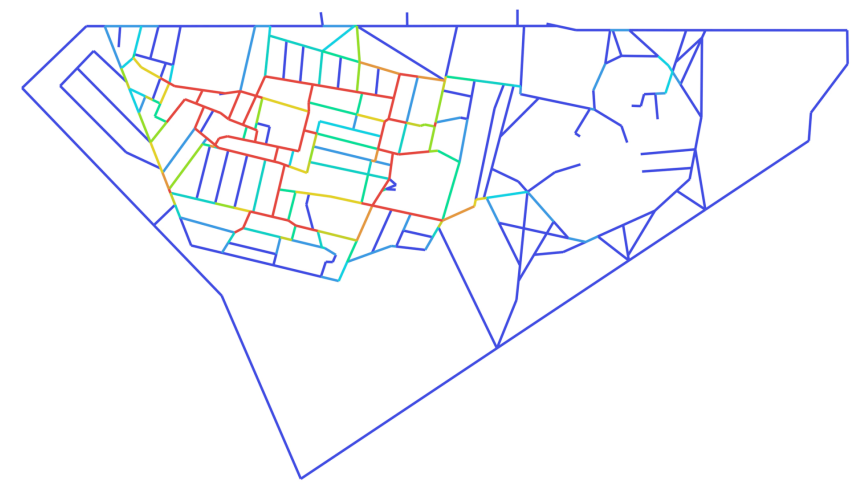

Figura 29b: Mapa de Segmentos, Escolha R400m. Fonte: Elaboração própria.

A seguir apresentamos os resultados da análise sobre as principais atividades, potenciais geradoras de dinâmica urbana e diversidade social na Vila Planalto. Entendese a dinâmica urbana como as atividades que acontecem ao interior do bairro e que têm potencial de promoção da vitalidade urbana (MONTEIRO; CAVALCANTE, 2012), ou seja, usos que contribuam para reunir a sociedade no espaço público (HOLANDA, 2013). Com base em dados estatísticos sobre usos de solo, altura de gabarito, área dos lotes e nível de renda, pretende-se estabelecer relações entre as variáveis para analisar as mudanças dos últimos anos em aspectos associados à diversidade da vida social do bairro.

As transformações na estrutura fundiária dos últimos anos, especificamente nos tamanhos dos lotes, são mais drásticas que as mudanças observadas nas condições socioeconômicas da população. O gráfico 12 mostra as mudanças na quantidade de lotes 
segundo seus tamanhos entre 2007 e 2013. É importante observar que os valores de 2013 foram obtidos do levantamento feito pela TERRACAP em 2013, enquanto os valores de 2007 correspondem a publicações de Holanda (2008, 2010, 2013) e levantamento da SEDUMA (2008).

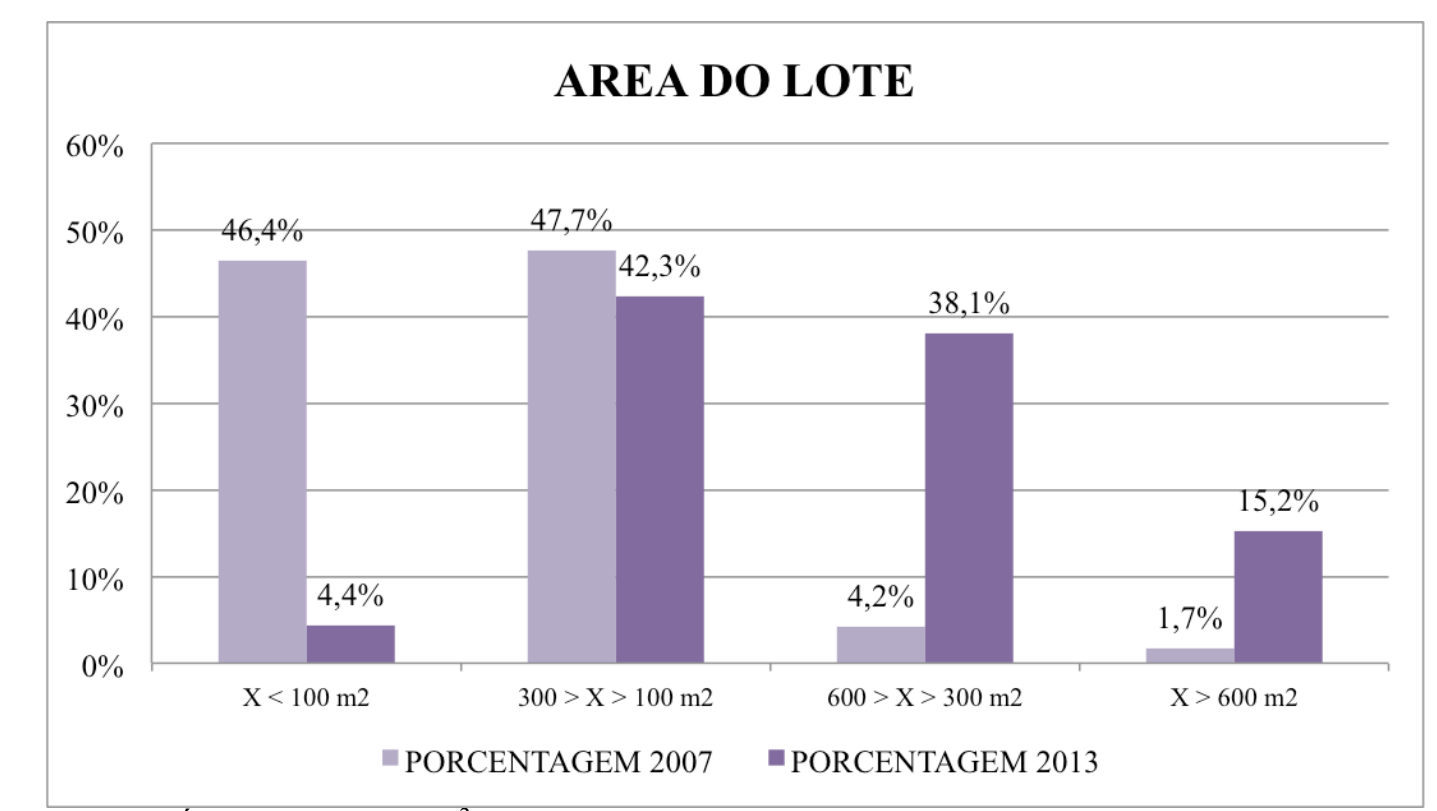

Gráfico 12: Área dos lotes em $\mathrm{m}^{2}$ nos anos 2007 e 2013 na Vila Planalto.

Fonte: Elaboração própria, com base em: SEDUMA, 2008; HOLANDA, 2010c, 2013 e TERRACAP, 2013.

Aprecia-se no gráfico 12 um aumento importante nos lotes entre 300 e $600 \mathrm{~m}^{2}$, que passam de 4,2\% em 2007 a 38,1\% em 2013. Os lotes maiores de $600 \mathrm{~m}^{2}$ também aumentam de 1,7\% a 15,2\% nos mesmos anos. Em contraste, os lotes menores de $100 \mathrm{~m}^{2}$ experimentam uma queda de 46,4\% em 2007 para 4,4\% em 2013. Essas transformações expressivas se explicam em grande parte porque para os valores de 2013 se considera o Setor de Chácaras, que nos últimos anos experimentou uma constante aparição de novos lotes de grande porte. Apesar da diferença na medição é importante observar a queda dos lotes menores de $100 \mathrm{~m}^{2}$, potencialmente ocupados por famílias de menor renda, que de forma remanescente se localizam nas áreas centrais do bairro.

O gráfico 13 mostra o desenvolvimento da quantidade (em porcentagem) de usos ou atividades desenvolvidas em cada lote do bairro para os anos 2009 e 2013. Os dados evidenciam um aumento das atividades comercias na Vila; o comércio passa de representar 2,3\% dos lotes em 2009 para chegar a 4,7\% em 2013. Os lotes que 
compartilham usos residenciais e comerciais também aumentam de 2,5\% em 2009 a $6,7 \%$ em 2013. Apesar de duplicar a porcentagem de atividades comerciais, a Vila Planalto ainda é predominantemente residencial. A principal questão em relação ao comércio na Vila não é o aumento do número de negócios, e sim a mudança no perfil dos usuários. Novos restaurantes apareceram para atender clientes de maior poder aquisitivo, restaurantes existentes se modernizaram para atender novas exigências. Restaurantes populares com preços baixos que abundavam antigamente hoje são a exceção.

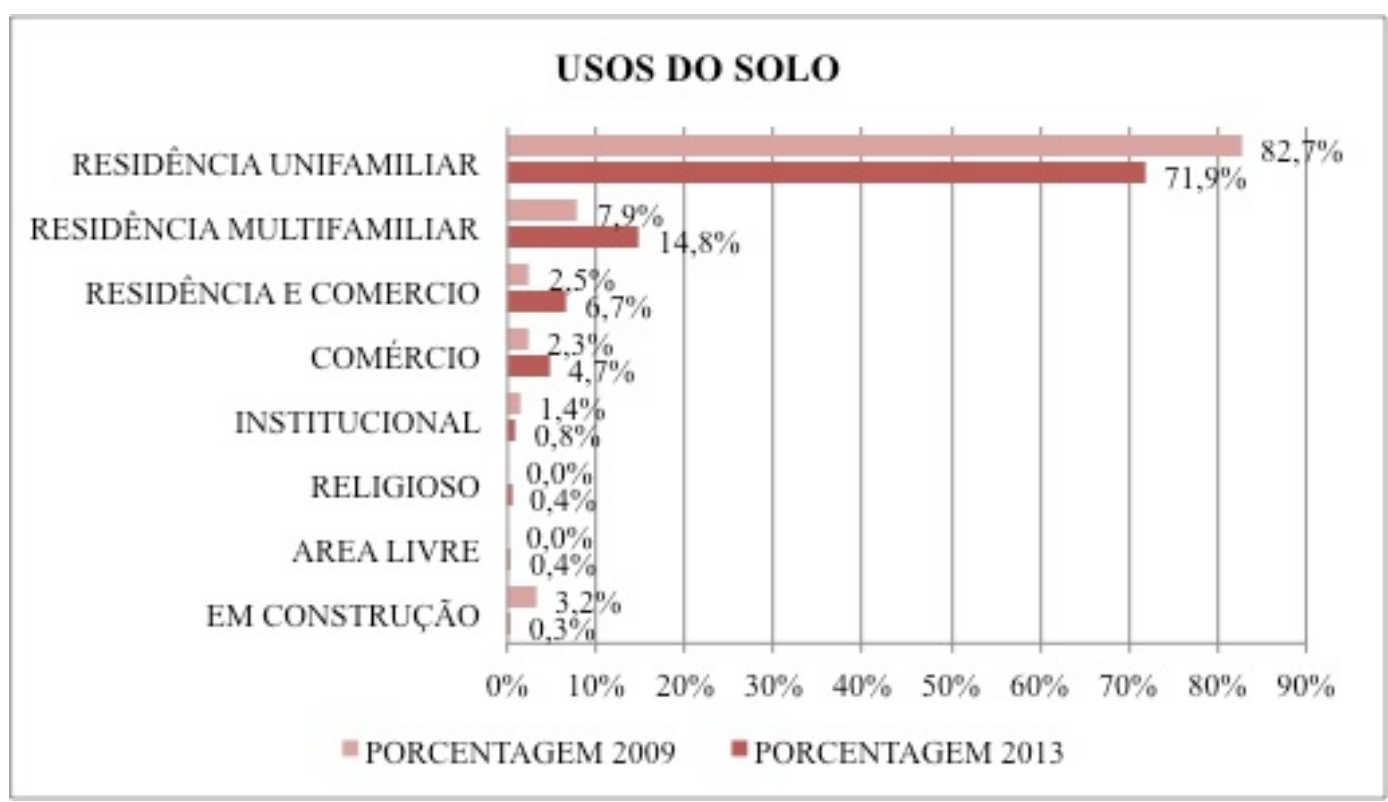

Gráfico 13: Distribuição (porcentagens) dos Usos de Solo nos lotes da Vila Planalto em 2009 e 2013. Fonte: Elaboração própria, em base a (SEDUMA, 2008; SEDUMA - CODEPLAN, 2009) e levantamento de dados in loco.

Concomitantemente ao aumento do comércio, observa-se a diminuição das residências unifamiliares, que passam de 82,7\% dos lotes em 2009 para 71,9\% em 2013. Em contraposição, as residências multifamiliares aumentam de 7,9\% para 14,8\%.

O aumento do comércio se explica pela ação do Governo do Distrito Federal, que, através da Secretaria de Turismo, instituiu, no ano 2010, o Projeto Vila Planalto: Gastronomia e Cultura. Esse projeto procurou fortalecer a atividade turística e comercial do bairro, tornando-o um "Polo Gastronômico e Cultural""16. O fomento à produção de turismo na Vila Planalto por parte do Estado pode ser interpretado como uma forma de gentrificação cultural (CHECA-ARTASU, 2011). Isso se deve a que o

${ }^{16}$ (SECRETARIA DE TURISMO DO DISTRITO FEDERAL, 2010, p. 4). 
Estado atua como gerador dos mecanismos que aumentam o valor do solo e do custo de vida, além do privilégio exclusivo sobre o patrimônio cultural da cidade e da sua gestão. Aproveitando as características de "cidade de interior" com pequenas ruas e vida tranquila, os restaurantes são intensamente utilizados durante a semana, principalmente por servidores que trabalham na Esplanada dos Ministérios, e durante o fim de semana por visitantes de fora do bairro.

A Figura 30 exibe um recorte do documento do projeto da Secretaria de Turismo, com um mapa da localização dos empreendimentos que fazem parte do circuito, principalmente gastronômico. Observa-se como a maioria das 32 iniciativas participantes localizam-se na via mais integrada do bairro, a L4 Norte. Existe uma concentração ao redor da Praça da Rabelo e na potencial centralidade reconhecível nos mapas de escolha.

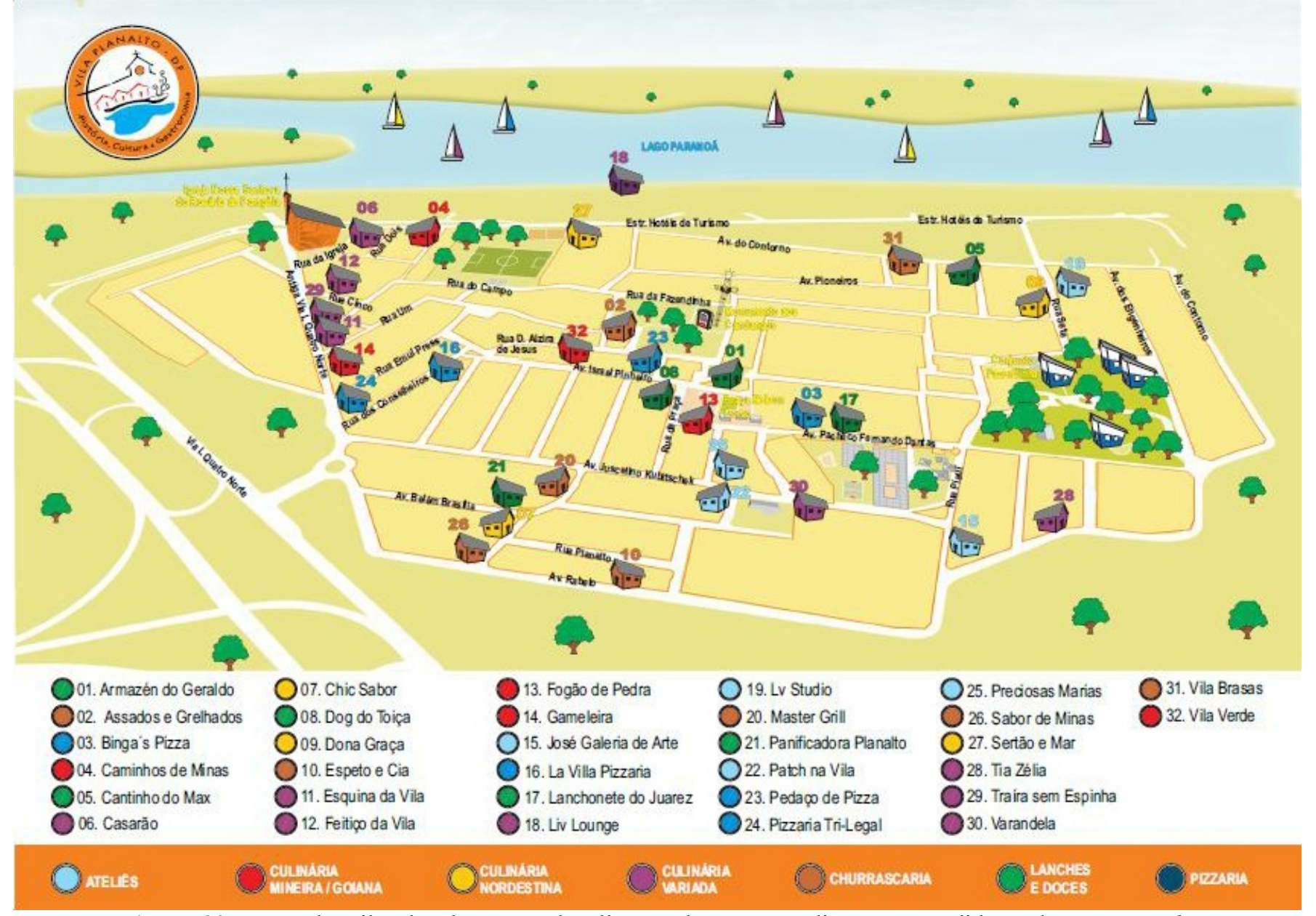

Figura 30: Mapa da Vila Planalto com a localização dos empreendimentos atendidos pelo Projeto Vila Planalto: Gastronomia e Cultura.

Fonte: (SECRETARIA DE TURISMO DO DISTRITO FEDERAL, 2010). 
A Vila Planalto possui legislação urbanística em vigência ${ }^{17}$, a qual indica que todas as edificações terão apenas um pavimento. Consequentemente, todas as edificações com mais de um pavimento existem de maneira irregular. Segundo dados da SEDUMA (2009), em 2006 fiscalizadores detectaram 176 unidades imobiliárias com dois ou mais pavimentos. Em 2009 esse número aumentou para 210 construções fora da normativa. Segundo o levantamento realizado em 2013 para esta pesquisa, foram identificadas 455 edificações com dois e até três pavimentos.

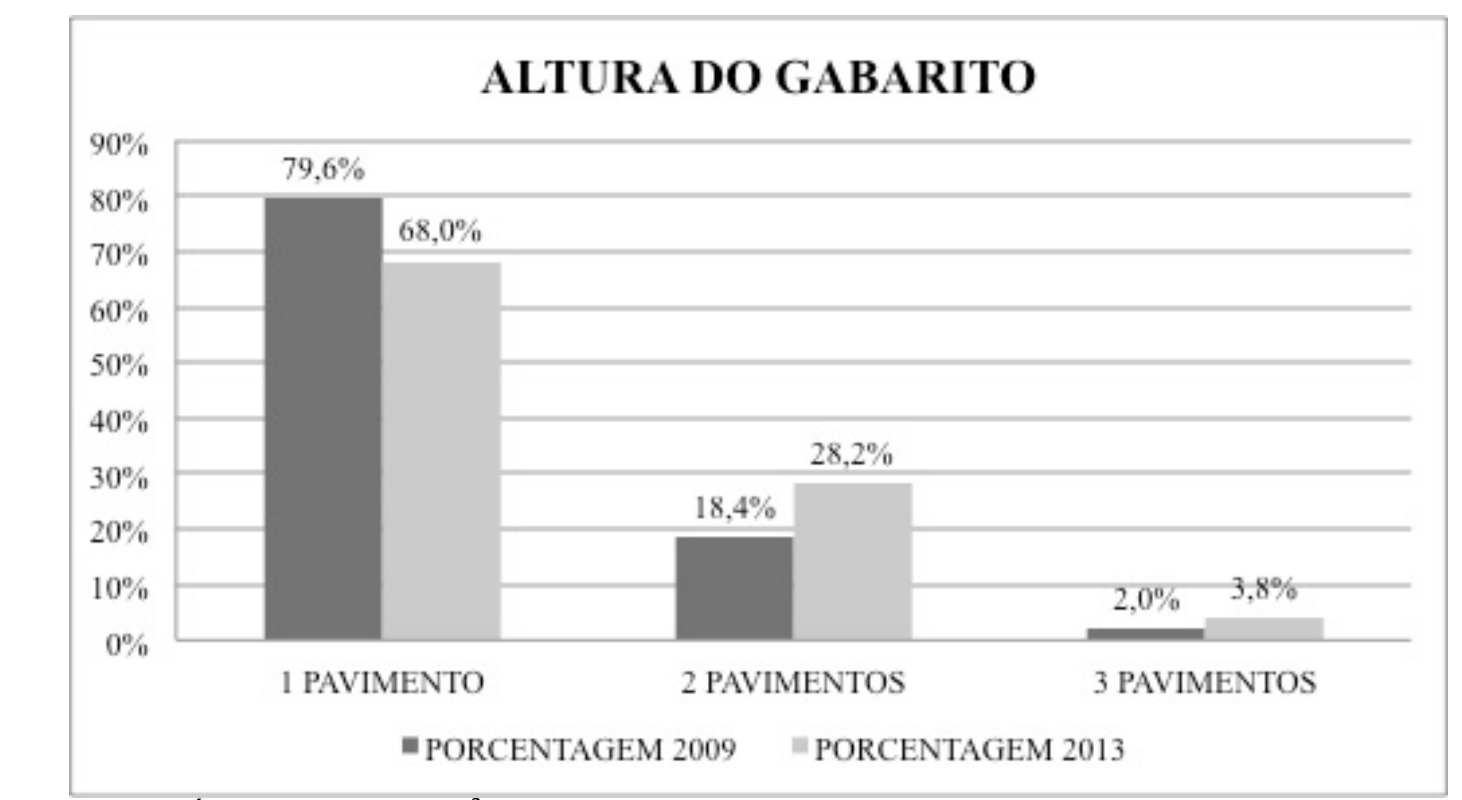

Gráfico 14 Área dos lotes em $\mathrm{m}^{2}$ para os anos 2009 e 2013 na Vila Planalto.

Fonte: Elaboração própria, em base a (SEDUMA - CODEPLAN, 2009) e levantamento de dados in loco.

Como se observa do gráfico 14, houve aumento das edificações informais ou irregulares no bairro. Entre o ano 2009 e 2013 as construções de um pavimento caíram do $79,6 \%$ para o $68 \%$ dos lotes para cada período. Ao mesmo tempo, as unidades de dois pavimentos aumentaram de $18,4 \%$ para $28,2 \%$, enquanto nas construções de três pavimentos o aumento foi de $2 \%$ em 2009 para 3,8\% em 2013.

\footnotetext{
${ }^{17}$ A legislação urbanística vigente esta composta pelos Decretos $\mathrm{N}^{\mathrm{o}} 16.22628$ de dezembro de 1994 e $\mathrm{N}^{\mathrm{o}}$ 19.082 de 11 de março de 1998. Também pelas Normas de Edificação, Uso e Gabarito, NGB 90/90, 163/90, 164/90, 165/90 e 58/91, pelo Memorial Descritivo - MDE 90/90 e pelo Projeto Urbanístico de Parcelamento - URB 90/90 (SEDUMA, 2008, p.11).
} 
O aumento na altura das edificações se relaciona diretamente com o aumento das residências multifamiliares na Vila, e correspondem, principalmente, a edifícios para aluguel de apartamentos e quitinetes. A ausência de controle e fiscalização, a ação de empreendimentos imobiliários e as necessidades de alguns familiares têm incitado o surgimento de mais edificações em 2 e 3 pisos, provocando a descaracterização física do bairro.

Para quantificar as relações entre as variáveis configuracionais e os aspectos da dinâmica urbana se estabelecem correlações. Primeiro, analisa-se qualitativamente as correlações visuais por meio de mapas e, segundo, apresentam-se resultados quantitativos obtidos por meio da contagem de correlações e posterior obtenção do coeficiente de Pearson (r).

A Figura 31 apresenta o cruzamento dos dados fornecidos pelo mapa axial de Integração Global com a distribuição espacial dos principais usos do solo na Vila Planalto. Em geral, observa-se uma tendência dos eixos menos integrados (cores frias) coincidirem com áreas de predominante uso residencial unifamiliar. Por outro lado, embora exista uma convergência de usos comerciais nas vias mais integradas (cores quentes) do bairro (L4 e EHT), grande parte dos lotes com usos comerciais se localizam no miolo da Vila que fica em torno dos espaços públicos abertos em vias de baixa integração. 


\section{CORRELAÇÃO USO X INTEGRAÇÃO}

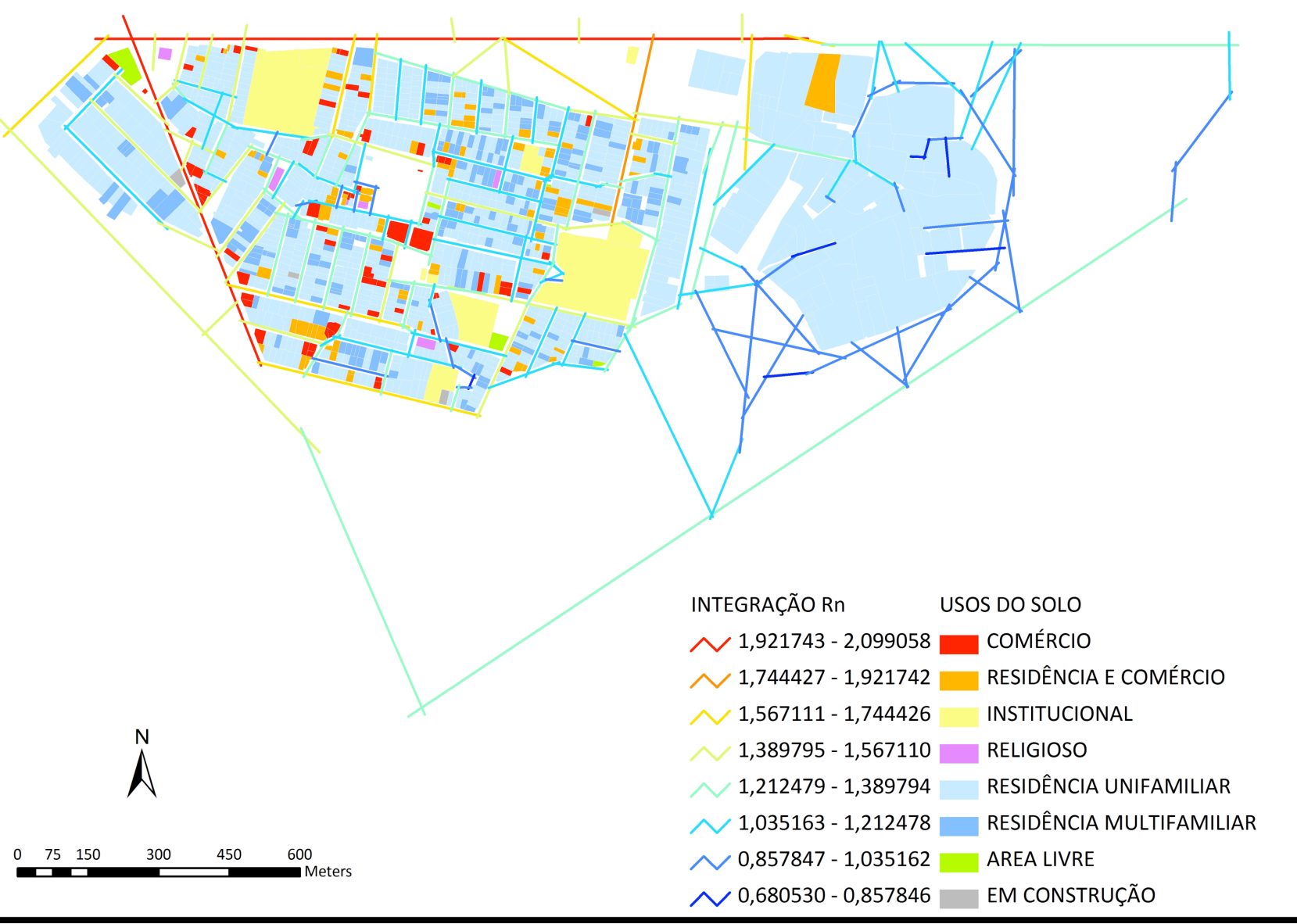

Figura 31: Correlação visual entre os Usos de Solo e a integração axial na Vila Planalto.

Fonte: Elaboração própria.

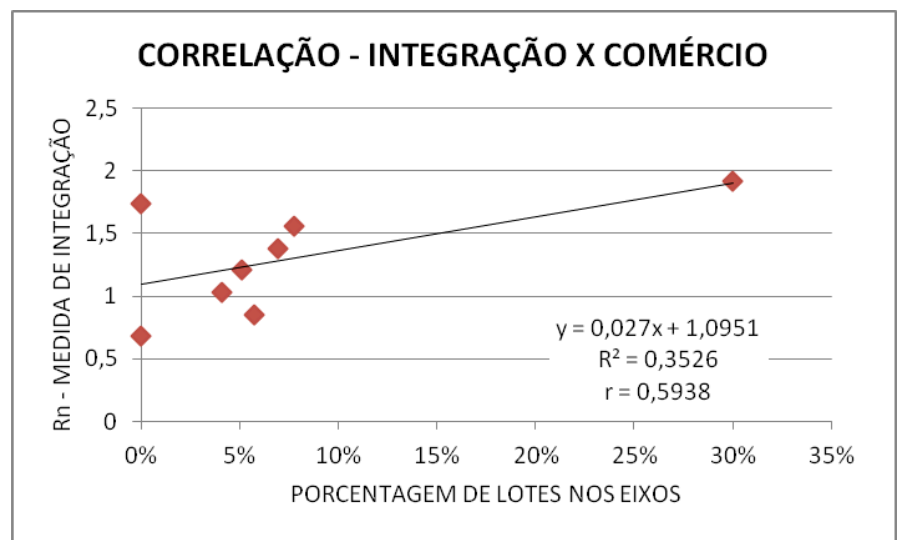

Gráfico 15a: Correlação entre Integração Global (Rn) e a porcentagem de lotes com usos comerciais.

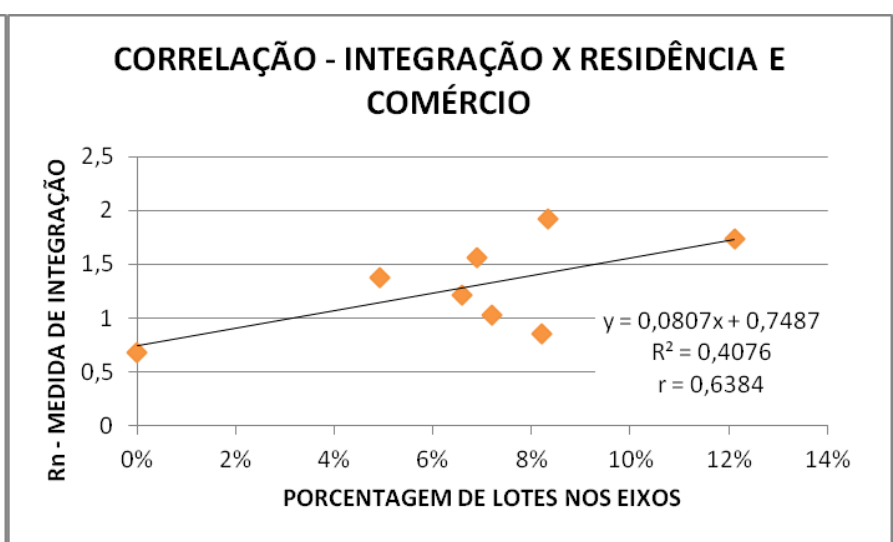

Gráfico 15b: Correlação entre Integração Global (Rn) e a porcentagem de lotes com uso residencial e comercial.

Fonte: Elaboração própria. 
Nos Gráficos 15a e 15b obtiveram-se os coeficientes de Pearson para analisar os níveis de associatividade entre as variáveis de integração e de usos do solo. O coeficiente de Person entre a Integração global e a localização dos usos comerciais (gráfico 15a) na Vila Planalto é de $r=0,59$, esse valor de correlação é classificado como grande (ver Tabela 1). Isso significa que existe grande correlação entre as vias com valores de integração altos e a presença de lotes comerciais. Os valores do gráfico $15 \mathrm{~b}$ também indicam grande correlação entre os eixos mais integrados e a porcentagem de lotes com residência e comércio. A convergência entre a integração axial e as residências unifamiliares apresentam os seguintes valores: o coeficiente de Pearson é $\mathrm{r}=$ $-0,83$, ou seja, uma correlação negativa muito grande. Isso confirma o observado nos mapas: nas vias menos integradas existe uma muito grande correlação a localização das residenciais unifamiliares. No caso das residências multifamiliares a correlação com as medidas de integração é de $r=0,01$, consideradas inexistentes.

O estudo das relações entre o controle espacial e a altura do gabarito (Figura 32) obedece à hipótese de que as vias com menor valor de controle podem apresentar maior concentração de edificações fora da normativa com dois ou mais pavimentos.

Quando se analisa visualmente a Figura 32 com o mapa de controle e altura do gabarito, observa-se uma leve correspondência entre os eixos com valores baixos de controle e as edificações com maior altura de pavimento. Reconhece-se como no Setor de Chácaras as edificações não passam de um pavimento, ao mesmo tempo em que no acampamento Tamboril não se observaram unidades com três pavimentos de altura. Os lotes com dois pavimentos estão distribuídos por todos os acampamentos, sem que seja possível reconhecer alguma concentração segundo a integração dos eixos. 


\section{CORRELAÇÃO ALTURA DO GABARITO X CONTROLE}

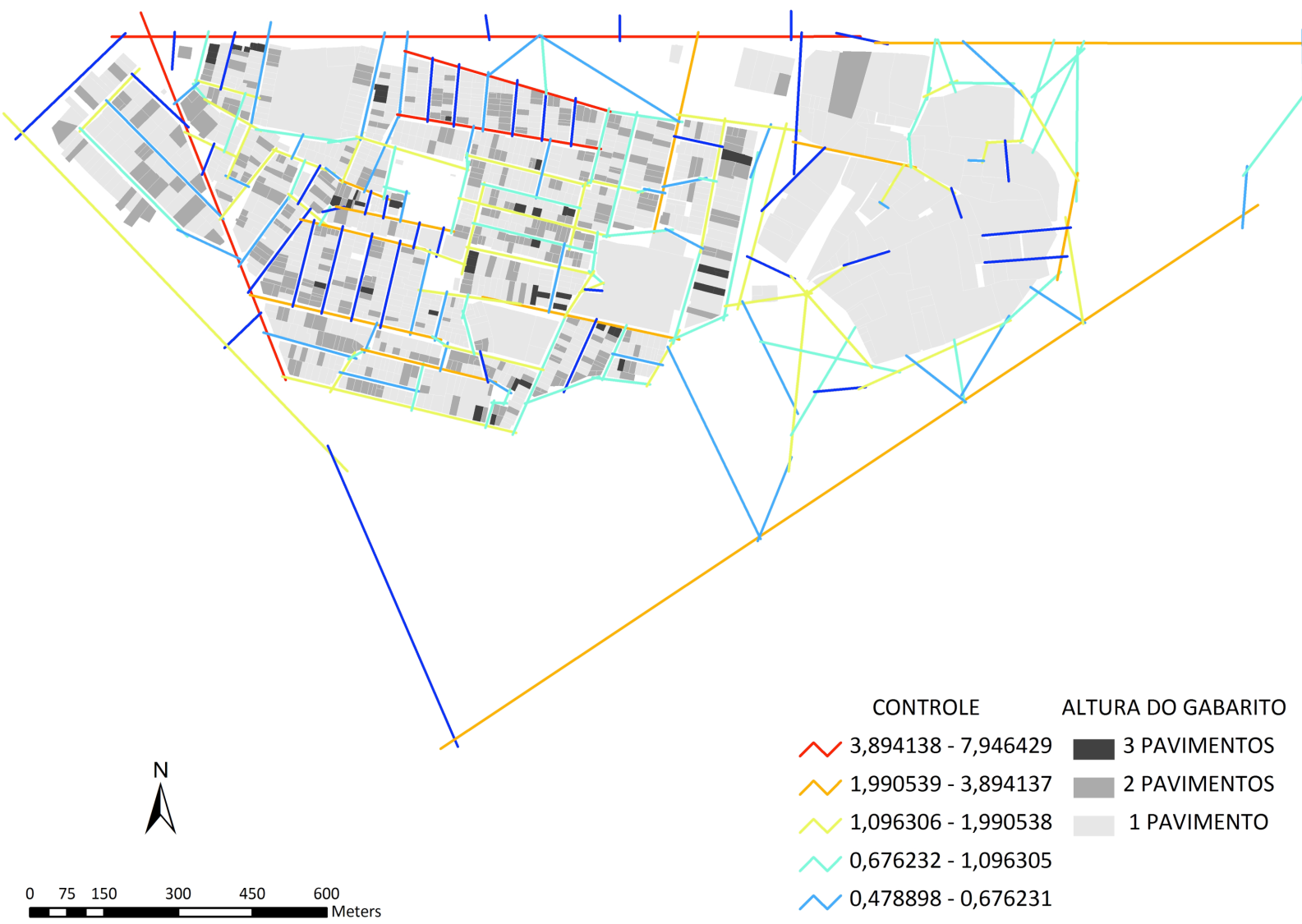

$\sim 0,058824-0,478897$

Figura 32: Correlação visual entre a medida de Controle axial e o numero de pavimentos na Vila

Planalto. Fonte: Elaboração própria.

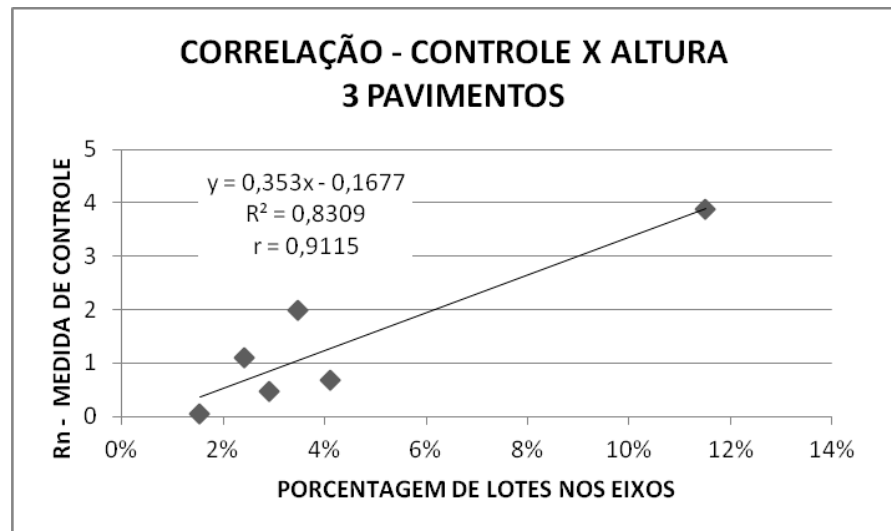

Gráfico 16a: Correlação entre o Controle e a porcentagem de lotes com 3 pavimentos.

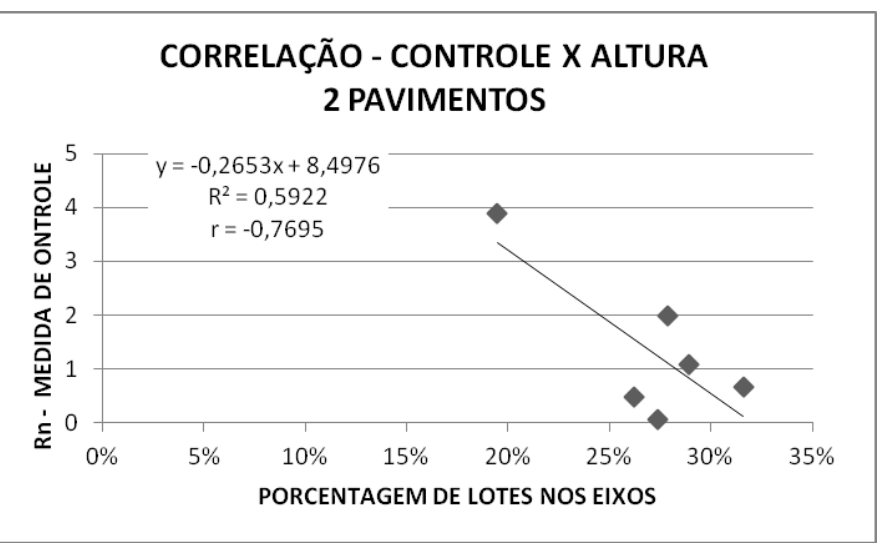

Gráfico 16b: Correlação entre o Controle e a porcentagem de lotes com 2 pavimentos.

Fonte: Elaboração própria. 
Os gráficos 16a e 16b indicam o grau de correspondência entre a medida de controle e a altura das edificações. Para os lotes com construções de três pavimentos (gráfico 16a), o coeficiente de correspondência é $\mathrm{R}^{2}=0,83$, e o coeficiente de Pearson é $\mathrm{r}=0,91$; esses valores indicam uma correlação quase perfeita, ou seja, à medida que aumenta o valor do controle nos eixos, aumenta também a presença de edificações com três pavimentos. O gráfico $16 \mathrm{~b}$ revela o confronto entre o controle e as construções de dois pavimentos. Os resultados geraram um coeficiente de determinação de $\mathrm{R}^{2}=0,59$, entendido como uma correlação grande. O coeficiente de Pearson foi de $r=-0,76$, o que corresponde a uma correlação negativa muito grande; isto significa que quanto menor controle dos eixos, maior será a concentração de lotes com dois pavimentos. Para um pavimento os valores foram de $\mathrm{R}^{2}=0,004$ e $\mathrm{r}=-0,06$, que indicam uma relação inexistente entre as variáveis.

Os resultados dos coeficientes forneceram dados que surpreendem e abrem caminhos para novas hipóteses. A correlação quase perfeita entre eixos com maior controle e lotes com três pavimentos, assim como a grande relação entre as edificações de dois pavimentos com eixos de menor valor de controle, levam a pensar que o Controle do espaço pode ser determinante na verticalização do bairro. Mas essa determinação tem características contraditórias. Por uma parte, os gabaritos de 2 pavimentos se localizam em vias pouco controladas, talvez, respondendo às necessidades de crescimento interior das vivendas para cada família. Por outro lado, as maiores concentrações de unidades com três pavimentos tendem a localizar-se em vias mais controladoras, esse maior controle pode ser entendido também como maior integração, respondendo, possivelmente, a unidades transformadas em residências multifamiliares para aluguel ou venda que precisam de melhor conexão ou integração para sua valorização. 


\section{CORRELAÇÃO INTEGRAÇÃO X TAMANHO DO LOTE}

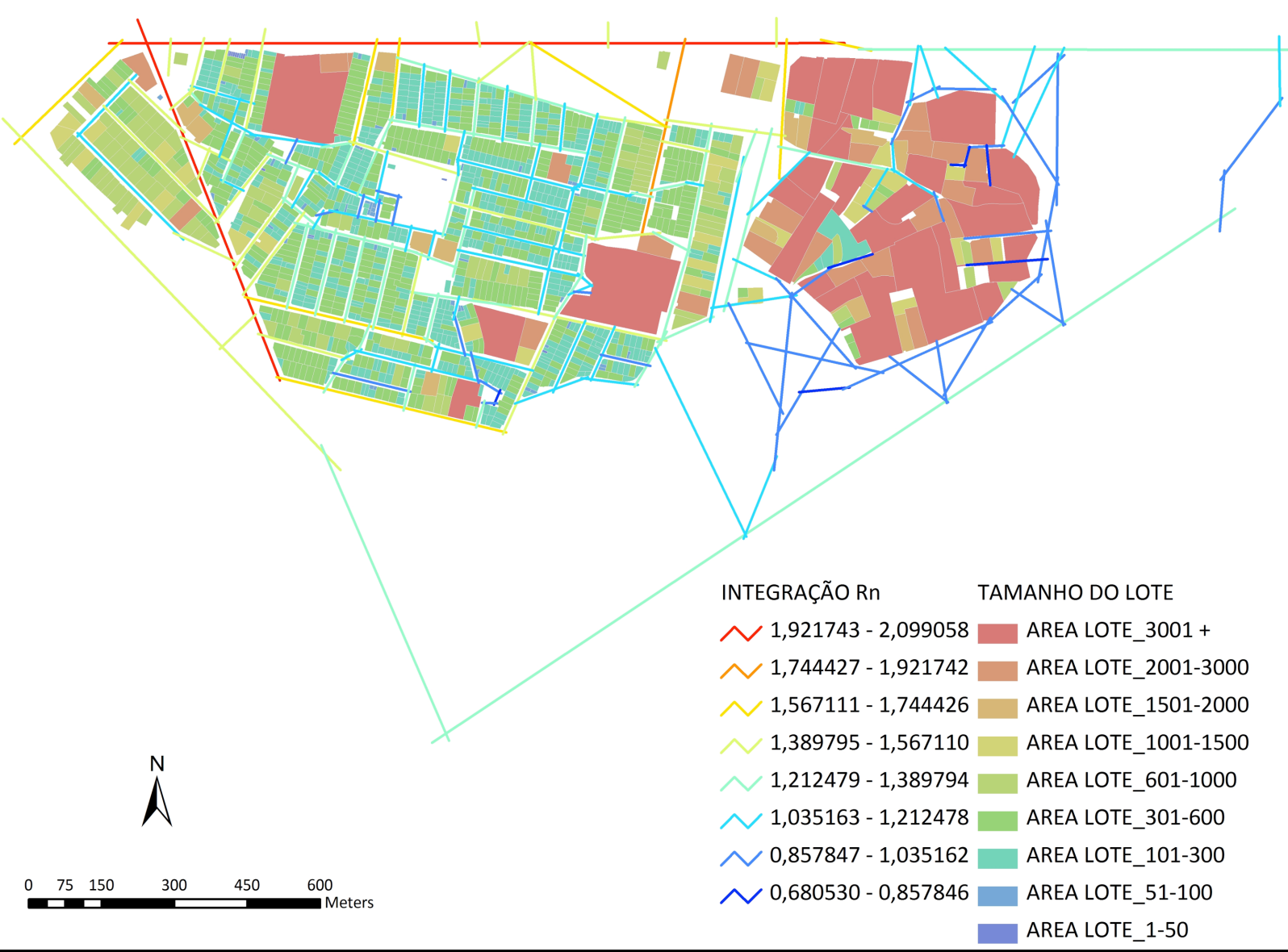

Figura 33: Correlação visual entre a medida de Integração Global e o tamanho dos lotes na Vila Planalto.

Fonte: Elaboração própria.

A Figura 33 mostra a correlação visual entre a Integração global e o tamanho dos lotes. Observam-se lotes de maior tamanho localizados principalmente no setor de chácaras, acessível por vias pouco integradas. Não se reconhece uma convergência entre as vias mais integradas do bairro e lotes maiores, potencialmente mais valorizados. Mas é possível diferenciar no acampamento Tamboril a predominância de lotes entre $300 \mathrm{e}$ $1500 \mathrm{~m}^{2}$. Os lotes menores de $300 \mathrm{~m}^{2}$ se posicionam em eixos pouco integrados do sistema, distribuídos em sua maioria no miolo dos acampamentos Pacheco Fernandes e Rabelo.

O estabelecimento de relações entre os valores de integração para cada eixo do sistema e os tamanhos dos lotes na Vila Planalto tem como objetivo analisar possíveis diferenças na distribuição de lotes mais ou menos valorizados. Diversos estudos (LIMA, 1999; MATTHEWS; TURNBULL, 2007; CHIARADIA et al., 2009; RODRIGUEZ et 
al., 2012) tem analisado o alcance da acessibilidade espacial ou integração de setores da cidade na valorização imobiliária dos lotes e residências. CHIARADIA et al. (2009) estuda as relações entre a localização e forma do desenho urbano com os preços das propriedades, através dos valores do impostos territoriais em Londres, notando que áreas com baixos valores de impostos associam-se a lotes pequenos, com alta densidade e próximos a áreas não residenciais. Para o caso brasileiro, o Imposto Predial Territorial Urbano (IPTU) é um instrumento urbanístico de contribuição físcal que se cobra sobre as propriedades em zonas urbanas. A base do cálculo do IPTU é o valor venal do imóvel que considera vários elementos, tanto do imóvel edificado como do terreno, para a definição do preço.

Uma variável relevante no cálculo do IPTU é o tamanho do lote e seu consequente valor de terreno, valor definido pelos municípios na Pauta de Valores de Imóveis (PVI) para incidência no IPTU. Em razão da impossibilidade de obter os valores do IPTU para esta pesquisa, na tabela 2 se apresentam os valores do PVI que incidem no cálculo para obter o valor do IPTU nos quatro acampamentos da Vila Planalto. Os valores da Tabela 2 indicam a importante diferença na avaliação das propriedades segundo a área do terreno. Para terrenos de até $300 \mathrm{~m}^{2}$ o valor do PVI é de R\$54.603, já para terrenos com mais de $1.500 \mathrm{~m}^{2}$ o valor do terreno quase duplica e vai para $\mathrm{R} \$ 109.206$.

Tabela 2: Relação entre tamanhos de lote (área do terreno) e seus valores segundo o PVI nos acampamentos DFL, Rabelo, Pacheco Fernandes e Tamboril na Vila Planalto.

\begin{tabular}{|c|c|}
\hline \multicolumn{2}{|c|}{ PVI - Pauta de Valores de Imóveis para incidência do } \\
IPTU \\
\hline ÁREA DO TERRENO $\left(\mathrm{M}^{2}\right)$ & VALOR DO TERRENO (R\$) \\
\hline $1-300$ & 54.603 \\
\hline $301-600$ & 68.254 \\
\hline $601-1.000$ & 81.904 \\
\hline $1.001-1.500$ & 109.206 \\
\hline $1.501-3.000$ & 136.504 \\
\hline $3.001-13.000$ & 887.302 \\
\hline
\end{tabular}

Fonte: Elaboração própria em base a Pauta de Valores de Imóveis para Incidência do IPTU (PVI) de 2013. (Secretaria do Estado da Fazenda - GDF, 2013). 
Os Gráficos 17a e 17b quantificam a relação da integração axial com a distribuição dos diferentes tamanhos de lotes. A divisão dos tamanhos foi simplificada quando comparada à correlação visual. Para os lotes maiores de $601 \mathrm{~m}^{2}$ o coeficiente de Pearson é $r=-0,28$, o que constitui uma dependência negativa pequena. Os lotes entre $301 \mathrm{~m}^{2}$ e $600 \mathrm{~m}^{2}$ (gráfico 17b) apresentam um nível de dependência grande com a acessibilidade espacial, o valor de $\mathrm{r}=0,55$. O Gráfico 17 a revela os coeficientes para as porcentagens de lotes entre $101 \mathrm{~m}^{2}$ e $300 \mathrm{~m}^{2}$. O coeficiente de Pearson, $\mathrm{r}=-0,42$, indica uma correlação moderada negativa.

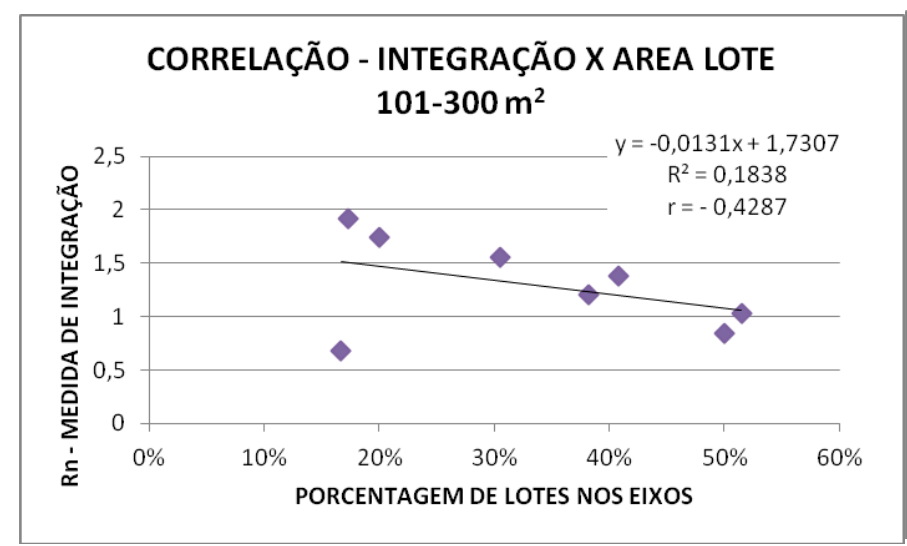

Gráfico 17a: Correlação entre Integração Global (Rn) e a porcentagem de lotes entre $101 \mathrm{~m}^{2}$ e $300 \mathrm{~m}^{2}$.

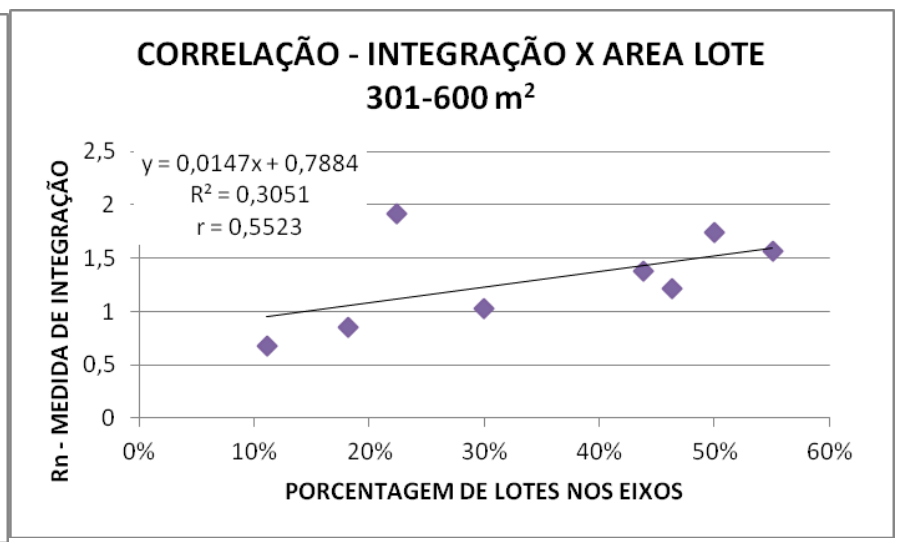

Gráfico 17b: Correlação entre Integração Global (Rn) e a porcentagem de lotes entre $301 \mathrm{~m}^{2}$ e $600 \mathrm{~m}^{2}$. Fonte: Elaboração própria.

Os dados fornecidos pelos gráficos de correlações entre a integração axial e a área dos lotes, não revelaram informações concludentes. Com a exceção dos lotes com áreas entre 301-600 $\mathrm{m}^{2}$, que apresentaram um grau de dependência grande, não se evidencia nos coeficientes uma relação predominante entre a acessibilidade e a localização dos lotes por tamanho. É possível sugerir que os lotes maiores (acima de $600 \mathrm{~m}^{2}$ ) não se localizam em função da valorização imobiliária e sim da falta de controle. Os lotes entre 600 e $300 \mathrm{~m}^{2}$, por outro lado, sim se localizam predominantemente em áreas mais integradas e potencialmente valorizadas. 


\section{ASPECTOS DO MODO DE VIDA}

\section{Cotidiano do bairro}

Nesta parte, analisamos o resultado do trabalho etnográfico, feito por meio de observações e entrevistas realizadas na Vila Planalto durante visitas em 2014 e durante meu dia a dia em 2015. Realizaram-se mais de 30 entrevistas, algumas anônimas, a modo de conversações informais, outras 12 como parte de um questionário socioeconômico. O questionário foi desenvolvido como uma experiência piloto no acampamento Tamboril, escolhido por ser o menor acampamento em numero de domicílios e o aparentemente mais valorizado. Outras 13 entrevistas, com base em 10 perguntas semiestruturadas, foram realizadas em espaços abertos de uso público, como rua, praças e bares do bairro. Para este trabalho, 10 entrevistas foram transcritas e selecionamos as respostas de seis moradores antigos (residentes há mais de dez anos) e de quatro moradores recentes.

No bairro, durante toda a semana e em diversos horários, é possível observar um intenso movimento de pessoas nas ruas e comércio. O maior movimento concentra-se na Praça Nelson Corso, espaço onde durante a construção de Brasília se localizavam os equipamentos do acampamento Rabelo. A praça reúne as famílias que moram há mais tempo na Vila e constitui um espaço vivo, intensamente utilizado nas tardes e nos fins de semana por pais que levam seus filhos para brincar, adultos que sentam para conversar, ou jovens e adolescentes. Nas sextas e sábados é possível ver crianças brincando até meia-noite nos jogos da praça.

Como se observa na Figura 34, durante o fim de semana de carnaval de 2014 foi realizado um show ao vivo, evento que congregou grande número de pessoas de todas as idades. Neste espaço, nas últimas sextas feiras do mês, acontece a "Feira Night" da Vila Planalto organizada pela AMVP. Na feira se vende comida, roupas e artesanato e reúne as famílias residentes do bairro. 


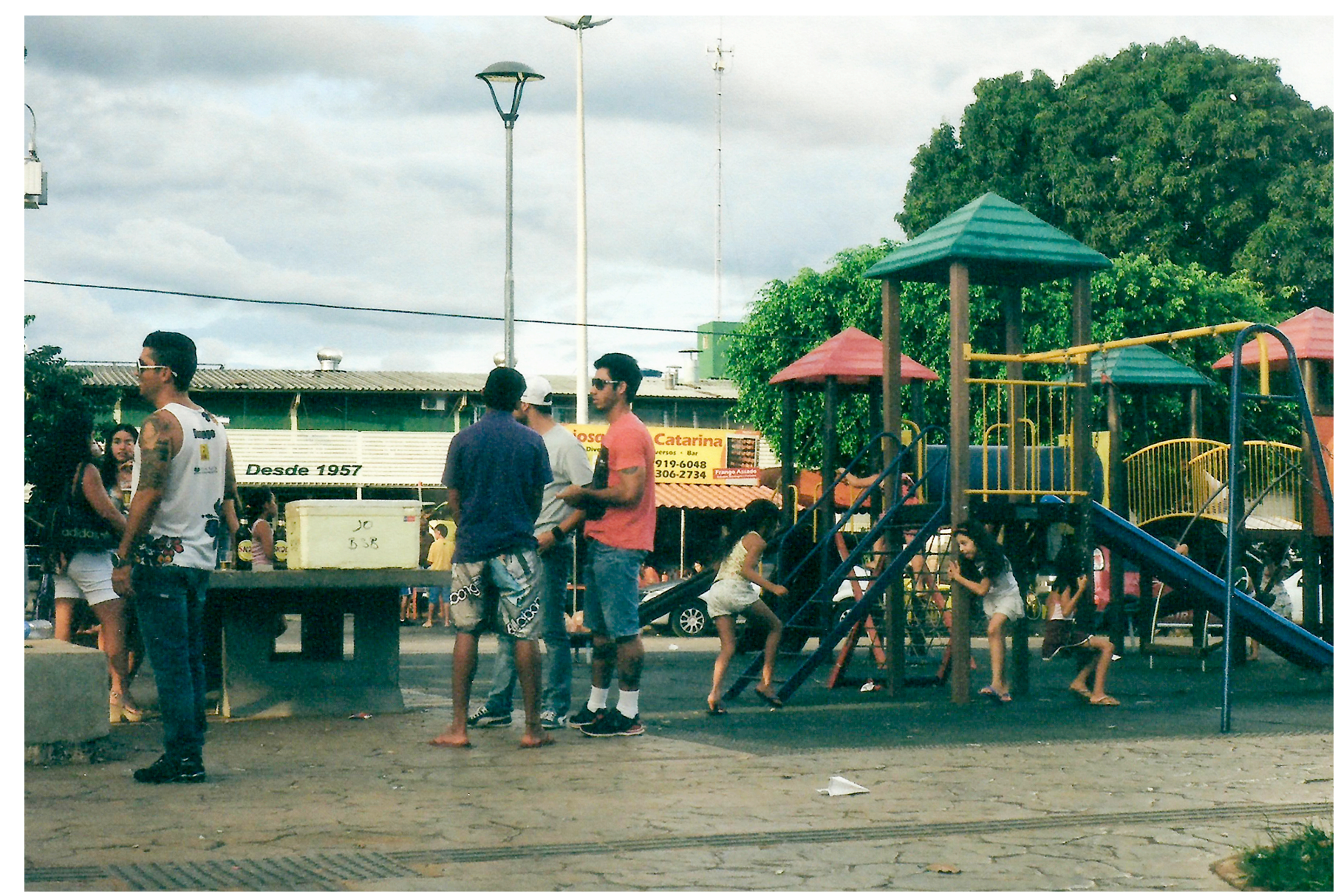

Figura 34: Praça Nelson Corso.

Fonte: Arquivo pessoal, (15.02.2014).

O principal comércio do dia a dia dos moradores se localiza no entorno da praça Nelson Corso. A seu redor há: um mercado, duas drogarias, uma loja de ferramentas e material de construção, uma casa lotérica, um restaurante, duas lanchonetes, dois bares, uma loja de roupas e um posto policial. Dos negócios, apenas o restaurante "Fogão de Pedra", situado na calçada sul, é maiormente frequentado por usuários externos, principalmente funcionários públicos que estacionam seus carros na praça entre $12 \mathrm{e}$ 14h. De segunda a sexta-feira, pessoas portando crachás e vestindo camisas sociais e calças escuras chegam da Esplanada para almoçar nesse restaurante, que serve comida a quilo. Durante o fim de semana são famílias inteiras as que chegam de fora do bairro para almoçar, movimentando o fluxo de veículos, mas sem outra relação com a praça ou com o bairro. À noite, entre $19 \mathrm{~h}$ e $22 \mathrm{~h}$, são os residentes voltando de seus trabalhos os que utilizam o espaço e o comércio da praça, principalmente o mercado "Armazém do Geraldo" e dois quiosques que servem churrasquinho e caldos, localizados na calçada norte. 
Outro espaço que faz parte da rotina dos residentes é a Praça Zé Ramalho ou praça da Rabelo (figura 35), que ocupa o terreno onde se localizavam os alojamentos coletivos durante o acampamento e posteriormente as moradias mais pobres e precárias já demolidas. Esse espaço recebe uma feira de frutas e legumes todas as quartas e quintasfeiras de manhã. Durante as noites se instalam barracas de comida. A praça é formada por um grande espaço aberto que tem um campo de futebol, um espaço pavimentado onde se põe a feira, uma área arborizada com aparelhos de exercícios para a comunidade, um memorial aos trabalhadores mortos durante a construção da capital, e uma casa remanescente habitada por uma família desde 1973. Existem dois restaurantes ao redor da praça com preços mais populares (refeição por $\mathrm{R} \$ 12$ ). De segunda a sextafeira, nesses locais é possível observar maior diversidade nos tipos de usuários: aqui comem trabalhadores de colarinho branco e de macacão.

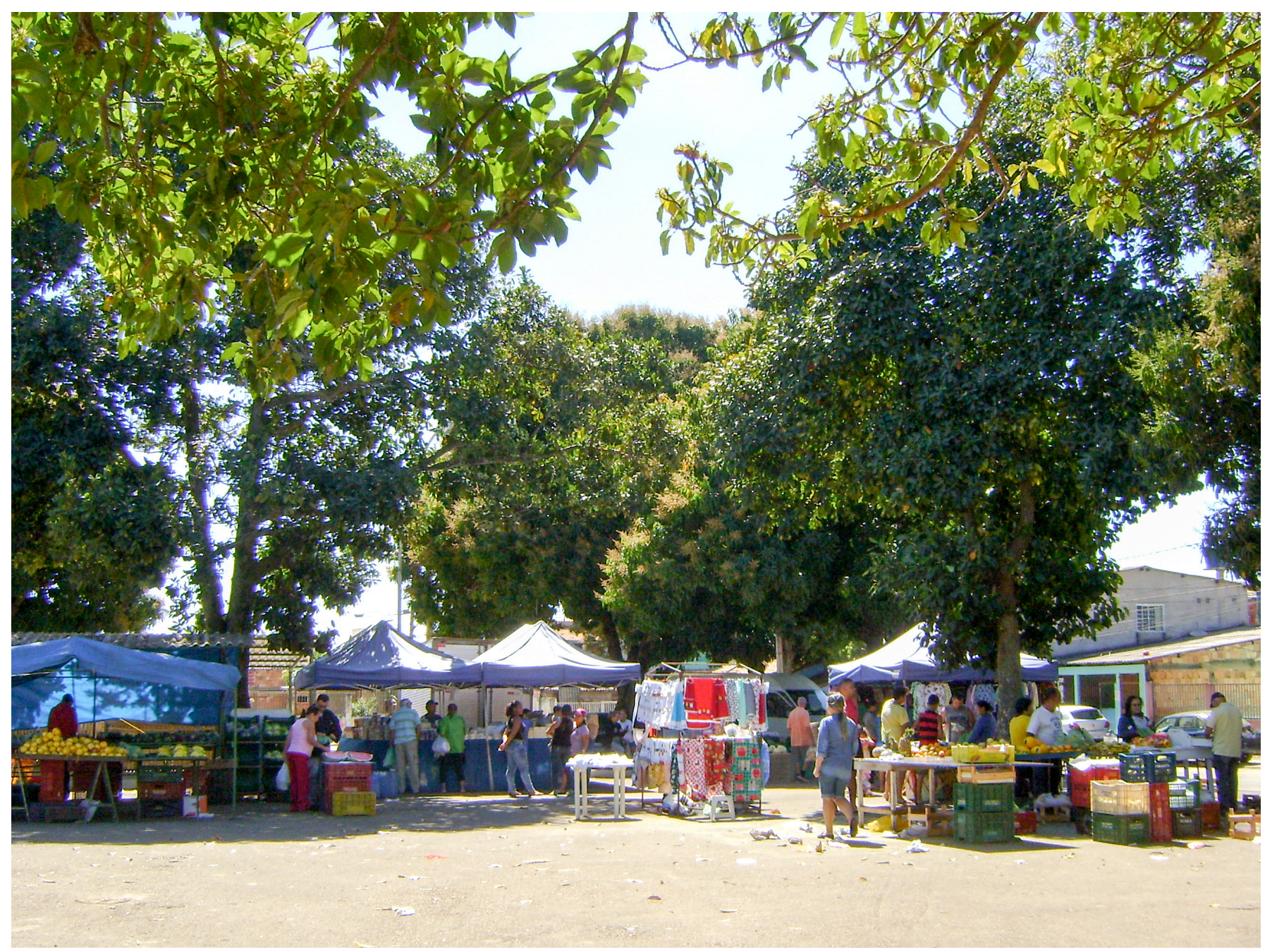

Figura 35: Feira da praça Zé Ramalho.

Fonte: Arquivo pessoal, (30.07.2015). 
Estes dois espaços abertos - as praças Nelson Corso e Zé Ramalho - representam uma centralidade nas rotas e rotinas dos residentes, que se mobilizam a pé, bicicleta ou de carro, principalmente, pela presença do comércio variado, de atividades culturais e de lazer frequentadas pelos moradores do bairro.

O espaço no extremo oeste da Vila Planalto, localizado nos setores que melhor se conectam com o resto da cidade, é frequentado por outros tipos de pessoas. Especialmente, nas proximidades da interseção das vias L4 e EHT se encontra forte concentração de restaurantes que atendem principalmente a usuários externos, moradores de outros bairros que se deslocam de carro para a Vila, gerando uma relação exclusivamente de consumo com o espaço. Esses restaurantes têm padrão e preços mais elevados, configurando em seu entorno um espaço elitizado, com movimento apenas durante os horários de refeições, e deserto em outros períodos do dia.

O restaurante "Casarão da Vila" é um exemplo de local que atende um público de maior poder aquisitivo, oferece comida a quilo e carnes além de música ao vivo nos fins de semana. Aberto de segunda a domingo somente em horários de almoço, o local cruza a rua para se apropriar da praça da Igreja do Rosário, instalando suas mesas para atender a seus clientes. Como se observa na figura 36, a praça da igreja é ocupada intensamente durante o funcionamento dos restaurantes apenas nas horas de almoço.

A igreja católica Nossa Senhora do Rosário de Pompéia foi mencionada por vários dos moradores como um dos lugares que mais frequentam. A Vila Planalto, segundo dados da SEDUMA-CODEPLAN (2009), registra 66\% da população que se declara católica. Esse dado, que parece significativo, não se traduz em maior apropriação do espaço onde a igreja se localiza. Quem assiste à missa vai exclusivamente à igreja nesses horários, sem utilizar muito a praça, apesar das boas condições em que se encontra. 


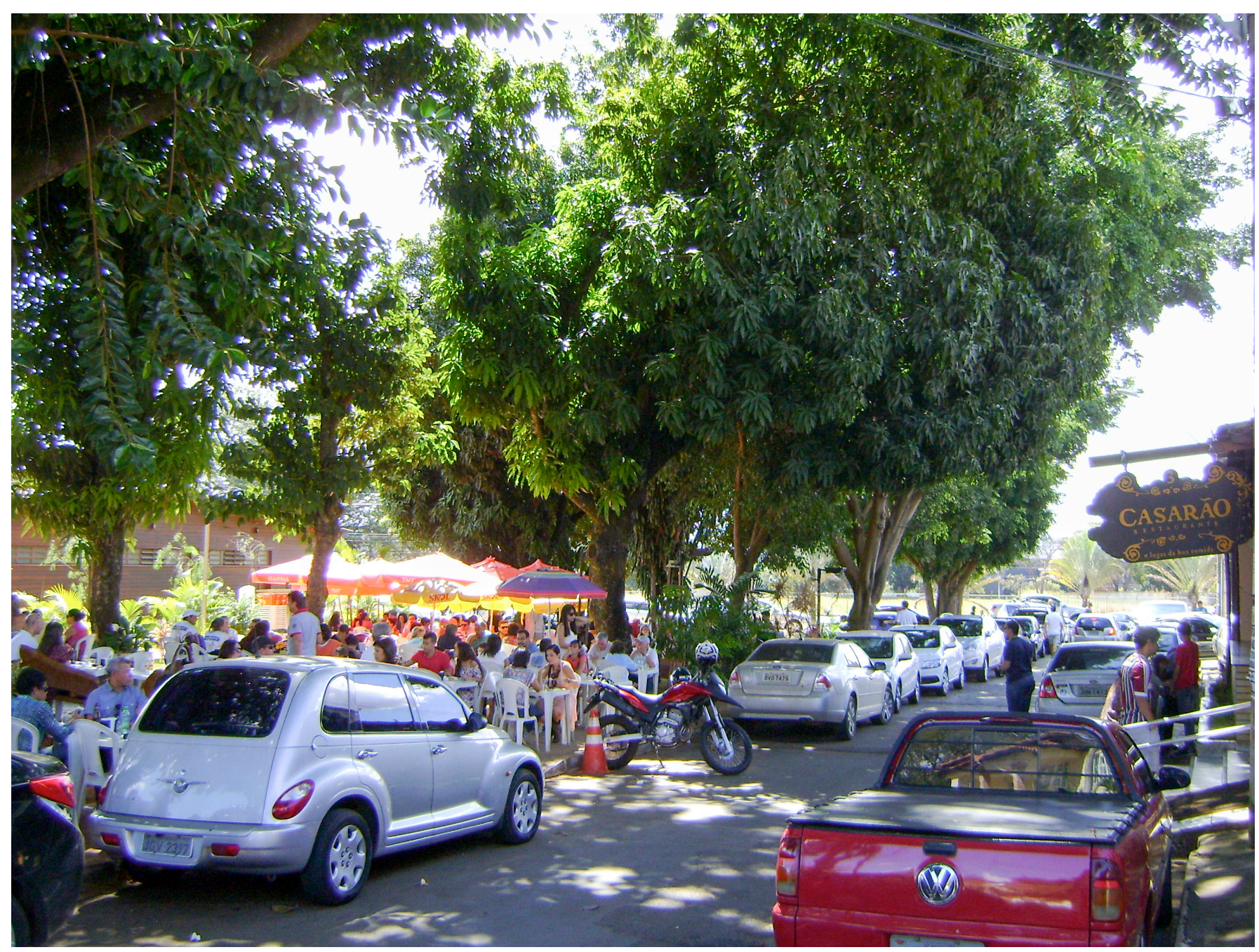

Figura 36: Praça da Igreja em frente ao restaurante Casarão da Vila.

Fonte: Arquivo pessoal, (03.08.2014).

Em relação aos cotidianos dos habitantes, informações obtidas a partir das entrevistas indicam uma diferença notória entre as atividades desenvolvidas por moradores que residem na Vila Planalto há mais de 15 anos em comparação com quem chegou há pouco tempo. Os moradores classificados como antigos - muitos deles se consideram pioneiros - têm uma idade avançada e correspondem, principalmente, a idosos ou aposentados, motivo pelo qual passam de segunda a sexta-feira dentro do bairro, realizando atividades em suas próprias casas. Aos domingos eles preferem sair da Vila: realizam visitas a filhos e netos que moram em outras áreas da cidade, passeiam pela orla do Lago Paranoá ou pelo Conjunto Nacional, ou frequentam o Clube Almirante Alexandrino que fica perto do bairro.

Quem chegou para morar na Vila Planalto há pouco tempo são em geral jovens estudantes ou trabalhadores, de rendas médias e médias baixas, que escolheram o setor por causa da proximidade com o Plano Piloto de Brasília, da acessibilidade em termos de dinheiro, bem como por causa do ambiente comunitário e familiar que o bairro 
oferece. Como reconhecem os próprios moradores, os novos residentes têm ritmo de vida mais acelerado, seu dia a dia transcorre entre a casa, o trabalho e a casa novamente. Alguns residentes que trabalham e estudam utilizam os restaurantes do bairro para comer algo à noite, pois, por suas atividades, não têm tempo ou vontade de cozinhar. Aos domingos, os mais jovens permanecem no bairro, à diferença dos moradores antigos. Por causa da rotina corrida, muitos jovens preferem descansar e permanecem no bairro para organizar assuntos em suas casas ou saem para tomar cerveja nos bares do local. Isto é feito por parte do grupo de residentes que utilizam o espaço de uso público e o comércio, pois na enquete domiciliar foi possível reconhecer outro grupo de moradores jovens que se relacionam com o bairro de forma contrária, sem quase frequentar os locais comerciais ou as praças.

Foi interessante encontrar o caso de dois diplomatas de intercâmbio, um de Moçambique e outro de São Tomé e Príncipe, que deixaram seus apartamentos nas superquadras do Plano Piloto para alugar uma quitinete ou um quarto na Vila Planalto. Segundo argumentam, isso não é só por causa dos preços mais acessíveis, também se deve ao caráter acolhedor da Vila, em contraste com a indiferença das pessoas da Asa Sul, onde moravam; eles reconhecem uma diferença na comunicação social, o que podemos interpretar como uma maior possibilidade de transgressões do cotidiano (GIANNINI, 2013) ou desvios dos trajetos, devido à presença de barzinhos, praças, conversações com vizinhos etc.

Dentro das conversações com vizinhos perguntamos sobre as mudanças no bairro, acerca de como eles observaram as transformações físicas e sociais desde sua chegada até hoje e como visualizam o futuro em relação à regularização fundiária em andamento, que deveria entregar as escrituras aos moradores mais antigos. Todos os moradores com quem conversamos ressaltaram que a Vila mudou muito. Quem está no bairro há mais de 15 anos destaca que quando chegaram, como as casas eram de madeira, com tetos de zinco, as ruas eram de terra, não existiam as mansões de hoje, assim como a vida era mais parada, sem muitas atividades de lazer ou comércio, mas as relações sociais eram mais próximas e de amizade, "todos se conheciam", dizem. Em relação à população, eles indicam que muita gente foi embora, a maioria, pioneiros que venderam seus lotes há 20 ou 30 anos. Ainda assim, reconhecem os novos moradores como "gente boa" e tranquila. Apenas uma pessoa mencionou que as mudanças foram para pior; a maioria vê as transformações no bairro como positivas, devido à chegada de infraestrutura, presença de negócios, a construção de condomínios de luxo na beira do 
Lago Paranoá e a chegada ao bairro de moradores com renda maior, o que para eles valorizou seu espaço.

A respeito da regularização fundiária, as opiniões sobre seus impactos são divididas. Apesar de que todos reconhecem que isto acarretará maior valorização dos imóveis, praticamente a metade não visualiza uma mudança na estrutura social da população. Segundo comentaram, já foram vendidos muitos lotes, então a maioria dos pioneiros saiu há muito tempo. Esse processo começou há mais de 20 anos, mas há 5 anos, aproximadamente, começaram a chegar novos moradores que coincidiram com o aparecimento da oferta de apartamentos e quitinetes para aluguel. Os moradores acham imperiosa a entrega dos títulos de domínio, considerada uma causa justa para quem mora há muito tempo, sendo uma necessidade para organizar o bairro.

A transferência das propriedades para os pioneiros começou em 2014, quando foram entregues as primeiras 22 escrituras, entre mais de 1.200 famílias que seriam favorecidas pela lei. O principal problema para a transferência é, segundo as autoridades da CODHAB, o descumprimento das normas urbanísticas (fracionamento de lotes, ocupação irregular de área pública, altura de gabarito) e a falta de documentação (concessões de uso vencidas, compra-vendas irregulares, heranças). Os vizinhos consideram que, com a escritura nas mãos, muitos começarão a vender seus lotes em razão da valorização imobiliária; para eles, se hoje as casas já se vendem a preços altos, com escritura esses preços serão ainda maiores, despertando o interesse de outros tipos de pessoas, talvez com nível de renda maior, o que poderia mudar o caráter do bairro, com a chegada de desconhecidos.

Alguns moradores mais antigos temem que o bairro se transforme em um grande condomínio. Ao contrário, para quem chegou há 15 anos ou menos na Vila Planalto, principalmente funcionários públicos que poderíamos identificar como um sujeito gentrificador ou primeiro colonizador do bairro, a possibilidade de vinda de novos moradores com maior poder aquisitivo é positiva devido ao seu "melhor" padrão de vida, o que - para eles - beneficiaria o bairro como um todo. 


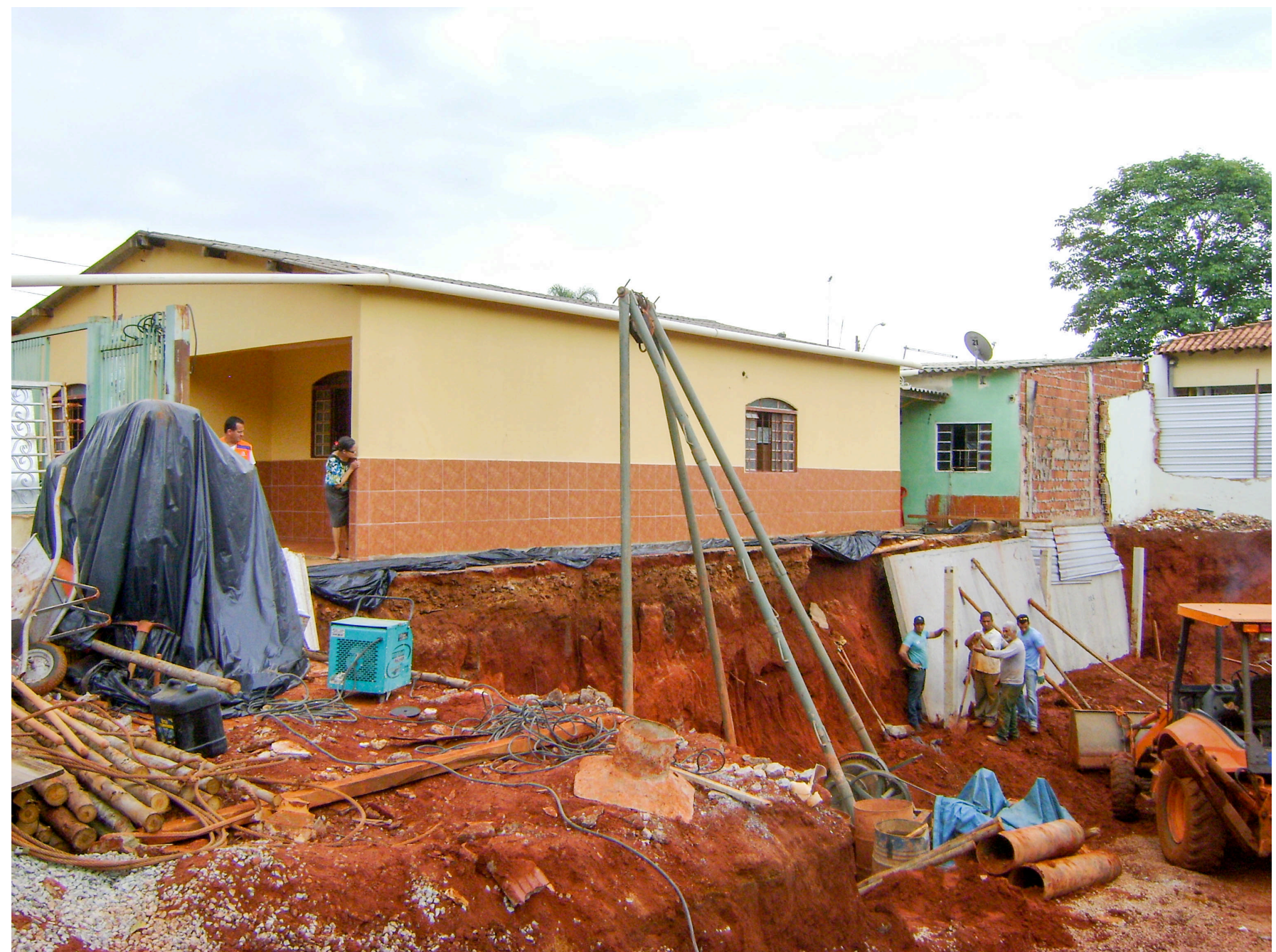

Figura 37: Dona da casa observa a obra do lote vizinho ao lado do fiscal da Polícia Civil.

Fonte: Arquivo pessoal, (23.10.2014).

A figura 37 mostra uma situação paradoxal na percepção dos moradores sobre a valorização imobiliária que foi constatada em 23 de outubro de 2014. Na Rua Piauí, em frente ao conjunto fazendinha, no acampamento Pacheco Fernandes, a Polícia Civil (segurança pública) foi acionada por uma família residente há 24 anos na Vila, vizinhos de um lote em construção. Após fortes chuvas na noite anterior e por causa da escavação no lote vizinho para construção de um prédio de apartamentos de dois andares com subsolo, um muro da casa tinha desabado causando temor nos residentes. Segundo a família, no início da obra autorizaram a construtora GNT a demolir o muro, pois eles construiriam um novo mais alto. Apesar do susto, alguns moradores consideravam a obra um benefício por valorizar seu lote já que morariam do lado de um prédio de apartamentos. 


\section{Lugares e gentrificação simbólica}

Entendemos o conceito de lugar como um espaço indentitário, relacional e histórico, seguindo o sentido do lugar antropológico, onde as relações entre as pessoas marcam fronteiras criadas pelas referências compartilhadas em contraposição aos nãolugares que seriam espaços genéricos, efêmeros e transitórios. Por sua parte, o conceito de espaço público vai além do lugar. Para configurar um espaço público, o espaço deve ser, além de indenitário, relacional e histórico, um espaço em disputa, não apenas de encontro social. O espaço público é: um espaço urbano de propriedade pública; um espaço semiótico, composto de signos que expressam as relações de poder; uma esfera pública, onde cidadãos engajados politicamente podem ser vistos sociabilizando; e, um espaço em disputa e de potencial conflito social, onde se expressam as diferenças e assimetrias de poder, renda, gênero, raça etc.

A respeito da importância dos lugares e da presença dos contra-usos, usos subversivos ou fissuras urbanas na construção do espaço público, é possível esboçar alguns potenciais lugares dentro da Vila Planalto. Reconhecem-se quatro espaços ou setores como potenciais lugares: 1) a praça da Igreja como lugar de consumo e lazer, 2) a praça Nelson Corso como lugar de encontro públicos e potencial espaço público, 3) a praça Zé Ramalho, também como lugar de encontro público, 4) o Armazém do Geraldo, lugar de convergência, e 5) o setor de oficinas, como lugar de fuga e transgressão, o espaço contra-enobrecido (Figura 38). 


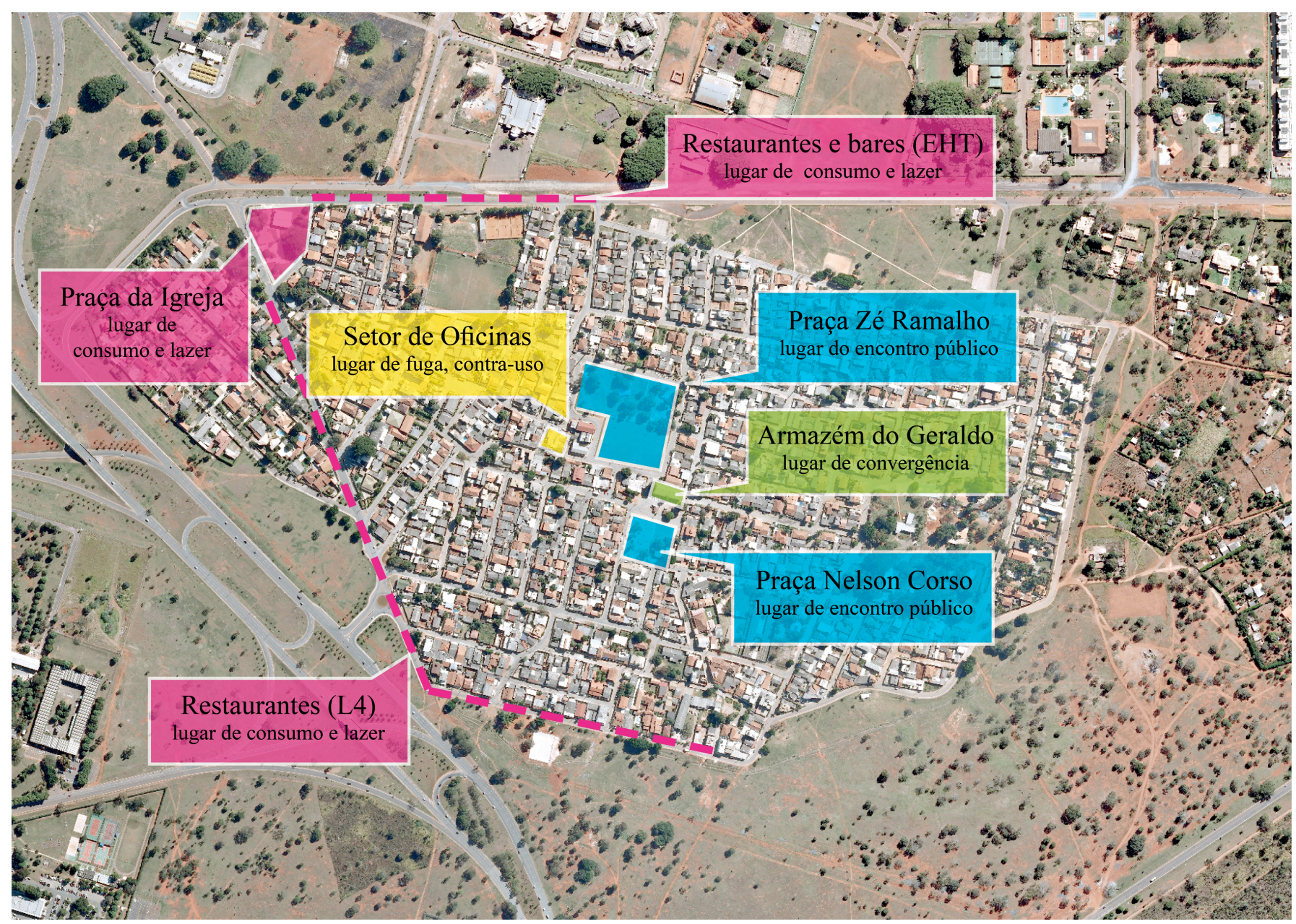

Figura 38: Mapa dos lugares da gentrificação simbólica na Vila Planalto.

Fonte: Elaboração própria.

O primeiro potencial lugar é a praça da Igreja de Nossa Senhora do Rosário do Pompéia, localizada no acesso ao bairro na interseção da via L4 e a EHT. Esse espaço, apesar das recentes reformas, permanece vazio grande parte do tempo; durante o horário de almoço e nos fins de semana ele se transforma em lugar de consumo. Os restaurantes em frente à praça se apropriam do espaço, instalando mesas na calçada. Durante os horários de missa, não existe permanência dos fiéis na praça. Durante 2015 foram realizadas algumas feiras de comida, música e artesanato chamadas de "feirinha da Vila Planalto", organizadas pelo coletivo Vilada, composto de alguns moradores jovens do bairro e de Brasília, alguns deles estudantes da UnB. Esse grupo também organiza o "festival do beco", que além da feira incorpora apresentações de bandas de música de diferentes estilos, num palco instalado numa viela da Vila próxima da praça.

Os eventos organizados pelo coletivo Vilada procuram a re-apropriação de certos espaços urbanos da Vila através de atividades culturais e consumo que visam um 
público mais amplo. As pessoas que frequentam esses eventos, são em sua maioria jovens não residentes do bairro. Em comparação com a "feira night" que acontece na praça Nelson Corso, se observa que os eventos na praça da Igreja são mais elitizados, oferecendo produtos gourmet, roupas e artesanatos mais caros.

O segundo lugar é a Praça Nelson Corso, que se poderia considerar como um potencial lugar do encontro público, um dos espaços mais vitais do bairro, ponto de encontro da vizinhança e lugar de shows para festas e celebrações. Aqui foi possível observar encontros com sentido político, como o que descreve Leite (2007) no Largo do Marco Zero. A Praça Nelson Corso é o lugar do bairro que podemos considerar um espaço público. O espaço reúne todo tipo de atividades, feiras, eventos, festas, reuniões comunitárias, atos políticos e protestos. Isso outorga o caráter de disputa e conflito no espaço urbano constituinte do espaço público. Um exemplo de ato político ocorreu no dia 7 de abril de 2015: vários vizinhos da Vila, junto com movimentos de ativismo ciclista, se reuniram na praça para iniciar um protesto pela morte de um morador atropelado por um motorista bêbado, enquanto pedalava de sua casa ao trabalho pela via L4.

Na praça Nelson Corso acontece algo semelhante ao que descreve Leite quando menciona a calçada-luz e a calçada-sombra, da Rua Bom Jesus (Pernambuco). Na praça Nelson Corso, seus dois lados se contrastam. No lado sul se localiza um restaurante mais requintado de comida mineira onde seus clientes parecem vir de fora do bairro e de carro. No extremo norte está o bar Quiosque da Catarina, de caráter mais popular e ao lado do Armazém do Geraldo, o local mais nomeado como reconhecido lugar de convergência e de consumo dos moradores novos e antigos.

Em frente à praça se encontra o "Armazém do Geraldo", terceiro potencial lugar e único equipamento que permaneceu do acampamento, indicado pelos moradores com quem conversamos como o principal mercado para realizar as compras do dia a dia dentro do bairro. $\mathrm{O}$ armazém foi destacado por vários aspectos, como sua posição estratégica - localiza-se na parte central do bairro - diversidade de preços e produtos, e como um ponto de referência no bairro.

Os moradores mais antigos ressaltaram que conhecem o Geraldo há muitos anos e que o espaço se transformou em um lugar de encontro entre amigos. O Armazém do Geraldo, como expressa seu cartaz, existe desde 1957 (Figura 39), representando a única loja de vendas do acampamento Rabelo durante a construção de Brasília. Como se 
observou nos depoimentos, ele é dotado de grande valor simbólico dentro do bairro, sendo um ponto de encontro aprovado por pioneiros, moradores antigos e não tão antigos. Apesar de o Sr. Geraldo não trabalhar mais no mercado, por sua avançada idade (atualmente o mercado é administrado por sua filha), os fregueses continuam fiéis e se inserem no tecido relacional que ali acontece.

Certeau (1996) menciona que o mercado é um importante ponto de referência sociológica que serve para compreender as relações humanas no interior de um bairro. O "Geraldo" é o principal mercado do bairro e passa por importantes transformações. Similar ao descrito por Certeau, com o "armazém do Robert" da Rue Rivet no bairro da Croix-Rousse em Lyon, o Armazém do Geraldo, na Rua da Praça, está dotado de grande valor simbólico. Os moradores mais antigos conhecem o Geraldo há muitos anos, quando ele mesmo atendia num pequeno negócio dentro de uma construção de madeira. Sem muito comércio dentro do bairro até os anos 1990 a maioria dos moradores comprava no armazém.

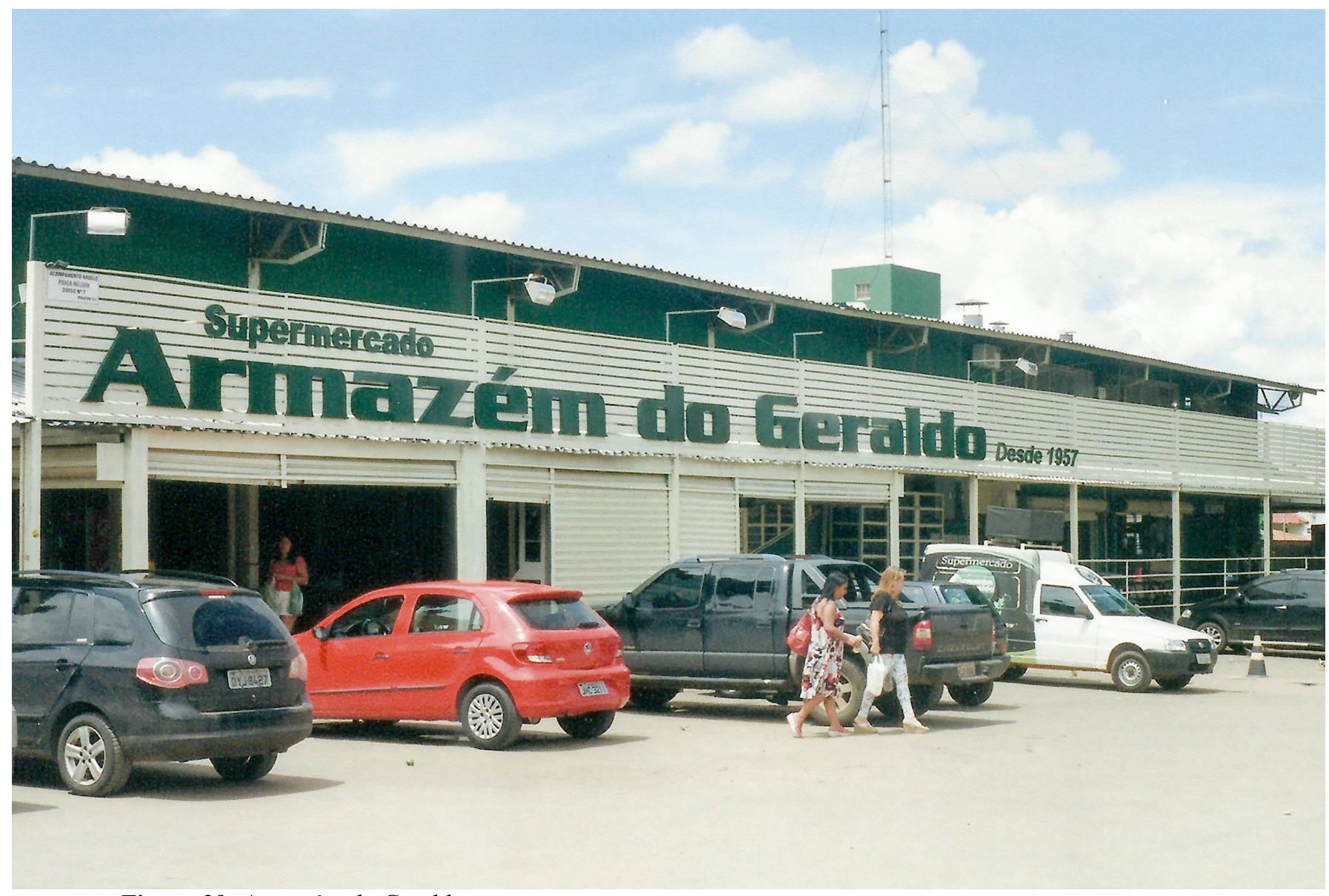

Figura 39: Armazém do Geraldo.

Fonte: Arquivo pessoal, (2014). 
A grande reforma do consumo provocada pela chegada de novos moradores na Vila Planalto aumenta a concorrência com o surgimento de diversos estabelecimentos comerciais. O Armazém do Geraldo é uma loja que conseguiu permanecer, desde a origem do bairro, modernizando-se segundo as novas práticas de consumo, porém sem perder as relações de sociabilidade. Na atualidade o mercado passa por obras de reforma para novamente adequar-se a fregueses de maior poder aquisitivo e para parecer com os grandes supermercados. Produtos importados e gourmet, cafeteria, iluminação e novos equipamentos são parte da nova imagem do Geraldo. Da mesma forma que os fregueses de Robert descritos por Certeau, os do Geraldo vivem um frágil equilíbrio entre premência do passado, as necessidades do progresso e seu poder aquisitivo.

Um quarto potencial lugar é a praça Zé Ramalho ou Rabelo, também de encontro público. Menos utilizada que a praça Nelson Corso, mas que reúne em diversas atividades vizinhos de diferentes níveis de renda. Duas vezes por semana se instala uma feira de frutas e legumes e pelas noites instalam-se barracas de comida. $\mathrm{O}$ espaço tem forte valor simbólico, já que ali se produziu a matança de trabalhadores durante a ocupação das construtoras e onde existe um memorial em homenagem. Apesar disso, no lugar não se observou um espaço de disputa que lhe acercasse a um espaço público no sentido descrito neste trabalho. Essa é a praça menos enobrecida das três observadas, conservando um caráter mais popular no interior e nas bordas do espaço.

Próximo a essa praça se localiza o setor de oficinas da Vila Planalto, que estabelece nosso quinto potencial lugar, um espaço contra-gentrificado numa área escondida, quase invisível. O setor situa-se no miolo do bairro numa área pouco acessível pela dificuldade de orientação que provoca o tecido urbano irregular rodeado de ruelas e becos. As oficinas de concerto de carros representam um contra-uso, no sentido normativo - está proibido na legislação vigente no bairro - e no sentido simbólico - por ser considerada uma atividade nociva ou poluidora é resistida, pois tende a desvalorizar o entorno. Apesar dos impedimentos, esses usos permanecem funcionando, favorecidos pelas condições espaciais do setor que lhe permitem o ocultamento.

O setor de oficinas é composto por um quarteirão de poucos lotes e as quatro pequenas ruas que o conformam. As oficinas não são o único uso proibido: em seu entorno, em certos momentos do dia, é possível encontrar jovens vendendo e consumindo maconha. $\mathrm{O}$ espaço parece ser um lugar de fuga que resultou em um lugar 
de refúgio, onde ações fora da lei podem ser realizadas. O setor de oficinas representa a paisagem antienobrecida, com suas construções de metal e lata, óleo correndo pelo pavimento, barulho de martelos, cheiro de tinta, e um ou outro cachorro mal-humorado. O espaço representa uma fissura da ordem urbana.

A subversão representada pelos atos ilegais no setor é constantemente atacada pelas políticas oficiais. Na minha curta experiência no bairro, já foi possível observar pelos menos três abordagens da polícia sobre jovens e adolescentes negros que caminham ou passam de bicicleta pelo local. Em todas as abordagens os jovens foram liberados por não portarem nada ilegal.

O disciplinamento do espaço é cada vez mas presente no bairro. Às continuas rondas e revistas da polícia se soma a crescente quantidade de câmaras de segurança instaladas nos domicílios, controlando os acessos às casas. Como se observa na figura 40, o setor de oficinas é uma exceção a este tipo de controle do espaço e não se encontraram câmaras instaladas no seu entorno. Esses mecanismos de vigilância se localizam com maior densidade nos acampamentos Tamboril, DFL e Pacheco Fernandes.

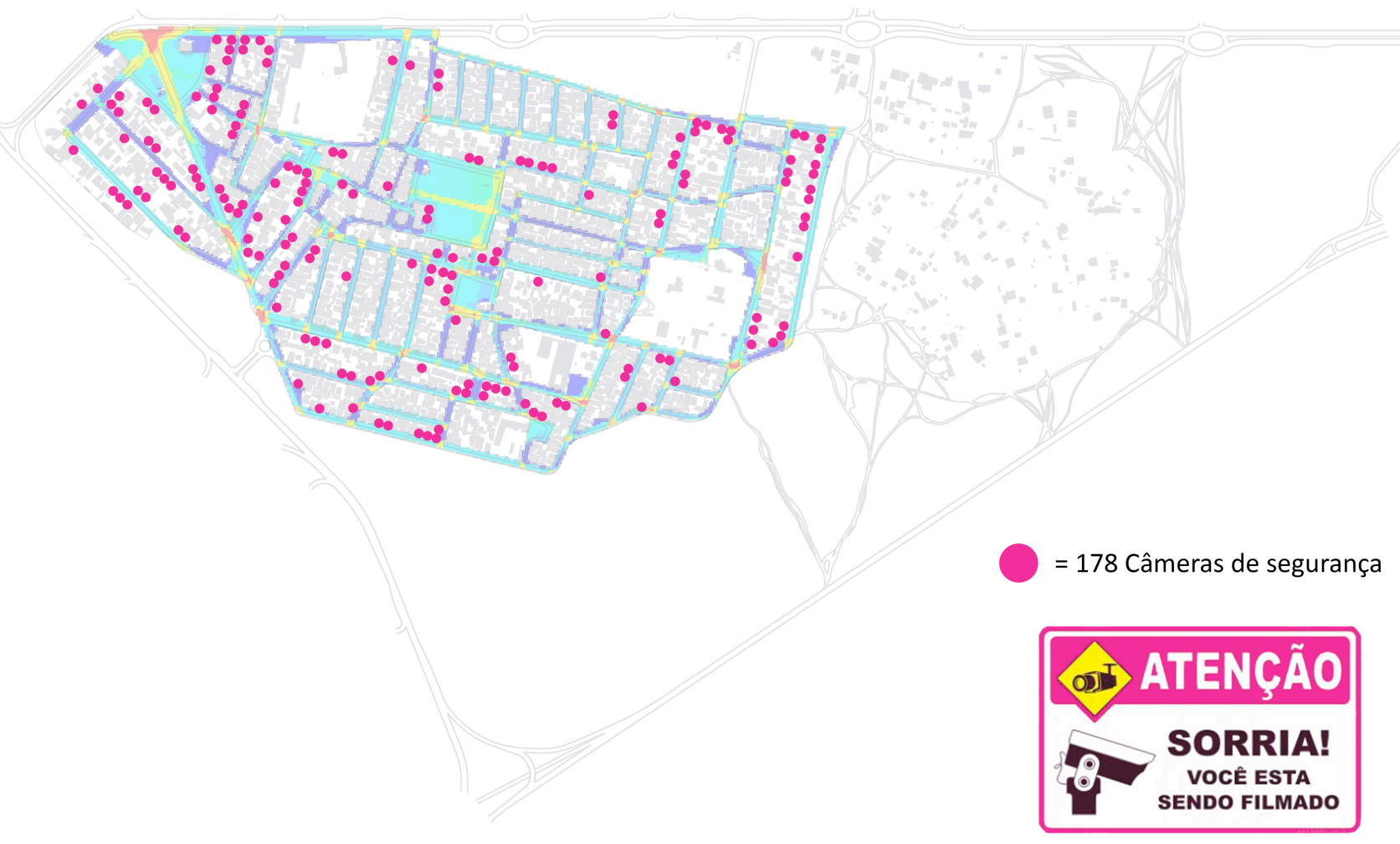

Figura 40: Mapa de Integração visual e levantamento das câmeras de segurança instaladas na Vila Planalto. Fonte: Elaboração própria, (2015). 
A Vila Planalto ainda é um bairro com predominante caráter residencial, mas os usos comerciais são cada vez mais presentes, assim como o nível dos estabelecimentos é cada vez mais alto. No bairro, o deslocamento de seus habitantes originais e de menor renda tem sido gradual e silencioso, não se registram grandes investimentos de capitais financeiros, ou grandes deslocamentos, são pequenos empreendedores, muitos deles os próprios residentes conformados por um pequeno grupo de pioneiros e uma maioria de primeiros colonizadores que capitalizaram suas aposentadorias e se converteram em rentistas, alugando quartos ou apartamentos construídos dentro de seus lotes.

Embora intervenções pontuais revitalizem alguns espaços da Vila, o processo de gentrificação é mais simbólico que físico. Não são grandes áreas de terreno as que se enobrecem, é como se desgranassem o milho, de lote em lote, por todo o bairro aparecem casas mais luxuosas ou apartamentos mais caros, desaparecendo os moradores mais pobres que não podem resistir ao aumento dos preços ou os pioneiros que não souberam tirar proveito de seu capital espacial. Embora as estatísticas indiquem um aumento de moradores de menor renda no interior do bairro, os trabalhadores manuais que chegam não permanecem morando de aluguel por muito tempo, apresentando alta mobilidade e rotatividade. Requisitos mais flexíveis para os locatários e a possibilidade de trato direto com o dono podem influenciar a escolha para pessoas mais jovens, em detrimento das superquadras.

As novas apropriações do espaço urbano da Vila Planalto por parte de moradores de maior renda e capital cultural correspondem a um conjunto de processo de produção espacial material e simbólica. Esses processos se situam em uma relação entre o sujeito que se apropria do espaço e os objetos do entorno que fazem parte da vida cotidiana dos moradores. Nas práticas empregadas na apropriação dos espaços gentrificados participam diversos agentes: o Estado, coletivos culturais, grupos de classe ou ações individuais, que tentam impor sua posição na cultura social.

A partir do trabalho etnográfico observamos a presença de capitais destinados ao fortalecimento do comércio e serviços vinculados ao lazer e o consumo, aumentando o nível de especialização exigido pelos consumidores de maior poder aquisitivo. Este processo leva a uma gentrificação comercial e em certos aspectos turística, que formam parte importante do processo total de deslocamento produzido pela gentrificação local. A gentrificação da Vila Planalto não é só um processo de transformação física, de deslocamento da população mais pobre e a chegada de novos residentes ou negócios. 
Também afeta a experiência urbana e as relações sociais dos residentes que tentam permanecer. Assim as transformações materiais e simbólicas manifestam as novas relações de poder e os conflitos de classe no bairro. 


\section{CONCLUSÕES}

\section{Conclusões do caso de estudo}

Várias cidades ao redor do mundo experimentam, de maneira simultânea, diversas forma de gentrificação com processos assimétricos de restruturação do capital, fluxos significativos de pessoas de rendas altas e médias e o deslocamento das rendas mais baixas pela privatização de áreas urbanas centrais (LEES; SHIN; LÓPEZ, 2015).

Nesta dissertação estudamos o processo de gentrificação na Vila Planalto, em Brasília, através das relações entre espaço e sociedade. Partimos da pergunta pela existência de limites ao processo, propondo como hipótese que as características locais são parte de uma estratégia global de gentrificação. Dentro das particularidades do caso brasiliense estariam as fronteiras estabelecidas pelos próprios moradores, que apresentariam limites ao enobrecimento de certos espaços. Para responder essa questão analisamos as transformações urbanas do bairro sob três aspectos: socioeconômico, configuracional e modo de vida.

Nos aspectos socioeconômicos estudamos a história urbana da Vila em relação ao desenvolvimento das políticas urbanas e das transformações demográficas mais recentes. Identificamos quatro períodos na historia do bairro: 1) provisório necessário, auge e desmantelamento (1956-1964), 2) abandono, estigmatização e fixação (19641988), 3) tombamento, colonização e transformações (1988-2010), e 4) Vila Planalto gourmet, valorização imobiliária e consumo do patrimônio cultural (2010-2015).

As políticas públicas são determinantes nos períodos históricos e marcam pontos de inflexão na história do bairro. Os quatro períodos se entrelaçam com as etapas descritas na literatura de gentrificação a nível global. Desde a saída das empresas dos acampamentos, a Vila passa por uma etapa de abandono e estigmatizacão, onde a maioria da população morava em situação precária e uma pequena minoria tinha melhores condições. Com o reconhecimento como patrimônio histórico, também se reconhece o direito à moradia dos residentes. Mas, o que começou com o GT-Brasília como um projeto de reabilitação terminou como uma estratégia de revitalização urbana estimulada pelo GEAP. Antes de 1988 já existia especulação com o valor da terra que provocava novas invasões à espera de receber lotes. Em 1992, com a entrega das 
concessões de uso das propriedades a especulação aumentou. Desde finais dos anos 1990 com instalação da infraestrutura básica no bairro, experimenta-se um encarecimento das condições de vida, potenciado, desde 2000, com a construção de condomínios, hotéis de luxo e clubes noturnos na beira do lago. Em 2010, com o projeto de desenvolvimento de um polo gastronômico, o governo tenta fortalecer o bairro como um lugar de lazer e consumo.

A substituição dos moradores originais é constante desde o tombamento, mas a expulsão dos moradores de menor renda (pioneiros ou não) se manifesta com maior força nos últimos anos, com o aumento dos estabelecimentos comerciais e da comercialização de imóveis para venda e aluguel. Como comentam os próprios moradores, a entrega das escrituras que começou em 2014 valorizará ainda mais as propriedades, o que sugere uma nova etapa de transformações. Várias casas registraram preços de venda acima de 2 milhões de reais. Em entrevistas no acampamento Tamboril, proprietários comentam que só venderiam acima de 3 milhões de reais. Isto seguramente incorporará novos agentes e maiores capitais no processo de gentrificação da Vila Planalto.

Com a análise dos dados do censo de 2000 e 2010 na Vila Planalto observamos um aumento nos residentes em condição de aluguel. $\mathrm{Na}$ renda do responsável pelo domicílio aumentam as rendas mais baixas (até $2 \mathrm{SM}$ ) e caem todos os maiores salários. Quando consideramos o entorno do bairro a situação é a oposta, aumentam as rendas acima de $10 \mathrm{SM}$ e caem todas as menores. Esses resultados poderiam ter uma correlação com a declaração de raça ou cor: em 2010 na Vila há mais pardos e negros e no entorno há mais brancos. Na variação entre 2007 e 2010, dentro do bairro, aumentam os brancos e caem os negros e pardos. Em 2009, 60\% dos moradores chegou antes de 1980 e $11,7 \%$ tinha mais de 60 anos.

A quarta parte da dissertação analisou as relações entre a forma da malha urbana e a distribuição dos usos de solo na Vila Planalto. Especificamente, analisaram-se as transformações históricas da malha viária, as mudanças recentes de elementos potenciais geradores de dinâmica urbana e estabeleceram-se correlações entre a atual configuração espacial e variáveis associadas à dinâmica urbana e sua distribuição no bairro. O estudo se concentra na morfologia urbana do bairro e seu impacto na distribuição dos usos do solo, altura de gabarito e tamanho dos lotes, para entender 
como a acessibilidade da malha urbana se reflete na presença de atividades socioeconômicas e na diversidade do bairro.

Com a realização da análise apresentada, foi possível reconhecer alguns pontos importantes na evolução urbana da Vila Planalto. Por meio da análise diacrônica dos mapas axiais, observa-se como a malha viária foi transformada pelos habitantes segundo suas necessidades. Dentro do processo de mudanças no arranjo espacial durante o período estudado (1964-2012) reconhecem-se três períodos, que são definidos pelas conjunturas históricas (ZARUR, 1991; COÊLHO, 2008) e ratificados pelas transformações físicas na malha viária.

O primeiro período, do qual não foi possível a elaboração do mapa, corresponde à época de maior intensidade na construção de Brasília entre 1956 e 1964, quando a Vila se estruturava a partir da união de até 22 acampamentos. A segregação e o controle do espaço eram totais.

Uma segunda etapa aconteceu entre 1965 e 1988, inicia-se com o abandono das empresas construtoras dos acampamentos e finaliza com o tombamento e fixação da Vila Planalto como patrimônio do DF. Em 1965, a malha viária se caracteriza por linhas mais longas e mais integradas que atravessavam vários acampamentos conectados com os canteiros de obras na Esplanada dos Ministérios. Com a saída das construtoras diminuíram os mecanismos de controle sobre o espaço e a vida cotidiana, ao mesmo tempo em que se inicia o desmantelamento dos equipamentos sociais. A Vila passa por constantes tentativas de remoções. A estrutura do traçado se fragmenta, desaparecendo as linhas globais, e os eixos se concentram no espaço correspondente a quatro acampamentos. A mancha urbana se compacta e tem um crescimento moderado.

O terceiro período ocorre depois da fixação e do tombamento, conforme os mapas axiais de 1991 até 2012. Efetivamente, quando se assegura a permanência da Vila Planalto no território, começam ou se evidenciam as transformações (COÊLHO, 2008): observa-se um adensamento interior e um aumento da mancha urbana, com o preenchimento dos vazios internos e da expansão para o setor de chácaras. $\mathrm{O}$ traçado resultante é cada vez mais irregular, fragmentado, essas condições se expressam na diminuição da conectividade, do comprimento médio de linha e do aumento na quantidade de linhas no sistema. O mapa de 2012 poderia indicar uma quarta etapa marcada pela duplicação das vias L4 e EHT. 
A análise dos mapas axiais e das medidas de integração, controle, inteligibilidade e sinergia revela a transformação da configuração urbana, que passa do formal ao informal. Para Medeiros (2006) é possível classificar estruturas urbanas segundo suas formas resultantes. Por um lado está o formal, planejado, regulado, legal, determinado, e no polo contrário está o informal, orgânico, ilegal, espontâneo, aleatório. Para Holanda (2002), é possível reconhecer duas tendências que podem ser sintetizadas como: paradigma da formalidade e paradigma da urbanidade. A "formalidade" diz respeito a que não é espontâneo, algo convencional que representa uma hierarquia e um sentido de autoridade. A "urbanidade" faz alusão a qualidades como o cortês, o afável, e também ao contínuo intercâmbio social. Assim, é possível interpretar a diminuição dos valores de integração global, inteligibilidade, conectividade e comprimento de linha, como resultado da transformação da malha urbana, que se adapta para uma forma cada vez mais rarefeita, portanto irregular e informal, o que faz o bairro adquirir maiores condições de urbanidade.

Essa informalidade também se expressa na fragmentação dos lotes, o surgimento de novos terrenos ocupados em áreas irregulares, a verticalização das edificações e as consequentes perdas das características físicas que levaram a Vila a ser tombada. A estrutura de controle do espaço dos acampamentos foi corrigida pela dinâmica dos processos sociais, que modificou o espaço por conta das necessidades da população e por pressões de renda fundiária (KOHLSDORF, 2010b). A fixação foi determinante para fazer da Vila Planalto um lugar mais desejado para morar, portanto um dos mecanismos que utilizou a sociedade para sua permanência foi o ocultamento e a proteção, por meio das transformações na forma construída.

A análise configuracional da estrutura urbana atual da Vila Planalto possibilitou o reconhecimento de características relevantes da forma do bairro. A partir do estudo dos mapas axial e de segmentos observam-se quatro partes componentes do sistema sem um núcleo de integração definido, mas com o cruzamento das vias mais integradas é definido o ponto mais acessível do bairro (L4 com a EHT). Com base nos mapas axiais de integração global, o bairro pode ser sintetizado em quatro partes: 1) Perímetro do bairro, os eixos mais longos definindo os limites do sistema; 2) acampamento Tamboril, área identificável desde a origem do bairro, composta por um traçado regular próximo às vias mais acessíveis e lotes predominantemente acima de $300 \mathrm{~m}^{2}$, reconhece-se como uma área socialmente homogênea com alto potencial de valorização imobiliária; 3 ) acampamentos DFL, Rabelo e Pacheco Fernandes, setor que concentra a maior 
diversidade em todos os aspectos, as vias com alta e baixa integração interagem, traçados regulares e irregulares, lotes grandes e muito pequenos, e concentra a maior quantidade de usos, o que aumenta a chance de encontros; 4) o setor de Chácaras é a área anexada que concentra as vias menos integradas do bairro em razão de sua forma irregular voltada para o interior, com estrutura de árvore.

Os mapas de segmentos, nas varáveis de integração e escolha, apresentam potenciais centralidades, principalmente para os raios de análise de $400 \mathrm{~m}$ e $800 \mathrm{~m}$. Os segmentos com maior integração e escolha se localizam ao redor dos vazios do bairro, espaços públicos como a Praça Nelson Corso e a Praça da Rabelo, lugares intensamente utilizados pela população e com forte presença de usos comerciais. Os mapas de segmentos demonstram uma maior precisão na análise visual, definido melhor os setores com maior potencial de integração, também os raios de análise voltados para distâncias percorríveis a pé (400 e 800m) evidenciam com maior claridade os potencias caminhos o rotas internas do bairro.

Em relação aos aspectos da dinâmica urbana, dados analisados alertam sobre uma drástica transformação nos tamanhos dos lotes, provocada pela expansão do setor de Chácaras. A Vila experimenta entre 2007 e 2013 um aumento dos lotes maiores de $300 \mathrm{~m}^{2}$ (de 5,9\% em 2007 para 53,3\% em 2013) e uma diminuição dos lotes menores de 100m ${ }^{2}$ (de 46,4\% em 2007 a 4,4\% em 2013). Portanto, se para Holanda (2007, 2010, 2013) o desempenho sociológico se relaciona diretamente com a diversidade espacial, a presença de diferentes níveis de renda poderia estar sob ameaça.

Os usos comerciais da vila mostram um aumento na quantidade de empreendimentos no bairro. Entre 2009 e 2013 registra-se um aumento dos usos comerciais e residências com comércio, consequentemente se observa uma diminuição dos usos de residências unifamiliares e um aumento das residências multifamiliares. Esse aumento do comércio se explica pelos incentivos do governo por meio do projeto Vila Planalto: gastronomia e cultura. Apesar das restrições na legislação, o surgimento de locais comerciais (passam de 2,3\% em 2009 para 4,7\% em 2013), assim como o aumento na altura das edificações de 2 pavimentos $(18,4 \%$ a $28,2 \%)$ e a diminuição dos lotes com um pavimento construído (79,6\% para 68\%), confirma o aumento de construções irregulares, da informalidade e de potencial crescimento da intensidade na dinâmica urbana do bairro. 
A análise das correlações quantificadas a partir dos gráficos e dos coeficientes de determinação e de Pearson permitiu obter resultados interessantes. Os valores do nível de dependência entre os usos comerciais e residência e comércio com a integração global foi classificada como grande. Com isso podemos confirmar que para um maior potencial de acessibilidade espacial (integração $\mathrm{Rn}$ ) existe maior presença de usos comerciais. Em contraste, a relação entre a Integração Global e os usos residenciais unifamiliares foi identificada como negativa e muito grande, ou seja, que para uma menor integração dos eixos, existe maior presença de vivendas habitadas por uma família só.

Em relação à diminuição do controle do espaço como facilitador da verticalização das edificações ao interior do bairro, os resultados foram contraditórios. Por um lado, as edificações com 3 pavimentos tem uma correlação quase perfeita com as vias de maior controle. Mas, por outra parte, os lotes com construções de 2 pavimentos proporcionaram uma relação negativa grande, isto quer dizer que as vias com menor controle axial têm maior concentração de lotes com 2 pavimentos de altura. Esses achados sugerem uma correspondência entre as edificações de 3 pavimentos e as vivendas multifamiliares (apartamentos e kitchenettes para aluguel) e que estas se localizam nas vias mais acessíveis, respondendo a uma lógica de valorização imobiliária.

Com a análise configuracional foi possível estabelecer relação entre a forma urbana do bairro e a localização das funções comerciais. Observamos, durante a história, como a sociedade modifica seu espaço que passa da formalidade e do controle social, durante a construção de Brasília, para um espaço informal com uma malha viária irregular, intensa atividade comercial e forte condição de urbanidade, reflexo das diversas relações sociais que acontecem no espaço urbano da Vila Planalto.

Com o estudo dos aspectos do modo de vida, na quinta parte da dissertação, foi possível reconhecer alguns aspectos importantes na vida diária da Vila Planalto. Observou-se que a informalidade é a principal característica desde a sua fixação, expressa em algumas relações sociais, na fragmentação dos lotes, no surgimento de novos terrenos ocupados em áreas irregulares, na verticalização das edificações e nas consequentes perdas das características físicas que levaram o bairro a ser tombado. A fixação significou o começo do processo de gentrificação, com a chegada de setores de classe média, principalmente funcionários públicos e profissionais. 
Com a realização das entrevistas, constatou-se que as relações entre os moradores mais antigos do bairro (pioneiros) e os novos residentes são quase inexistentes, da mesma forma como seus modos de vida parecem não se misturar no espaço civil (GIANNINI, 2013). Entretanto, alguns espaços significativos na prática cultural são reconhecidos, como algumas praças e o Armazém do Geraldo, lugar onde coincidem as trajetórias individuais e são atendidas as necessidades cotidianas (CERTEAU, 1996) dos mais diversos habitantes.

O caso da Vila Planalto se enquadra dentro do conceito de gentrificação simbólica (JANOSCHKA; SEQUERA; SALINAS, 2013), como sucede em outros bairros em que se envolve o patrimônio cultural com o turismo e lazer na América Latina. A Vila Planalto é um bairro com predominante caráter residencial, onde o deslocamento de seus habitantes originais tem sido gradual e silencioso, sem grandes investimentos de capitais financeiros, mas de pequenos empreendedores, capitalizando aposentadorias e convertendo-se em rentistas.

Com base nos conceitos de gentrificação, contra-usos e lugar e por meio da observação direta e da realização de entrevistas foi possível avaliar qualitativamente o desenvolvimento urbano da Vila Planalto, e determinar o caráter público dos espaços urbanos. Identificamos alguns tipos de residentes que fazem parte do processo de gentrificação: 1) moradores originais (pioneiros); 2) colonizadores chegados após o tombamento (funcionários públicos); 3) novas classes médias (jovens estudantes ou profissionais); 4) contra-gentrificadores, popularização (trabalhadores manuais).

Observamos como os antigos residentes surgem de duas etapas diferentes na história do bairro. Os moradores originais correspondem aos pioneiros, presentes há mais de 50 anos, desde a época da construção da capital, conformados por trabalhadores da construção civil, já aposentados ou de famílias que se trasladaram da desaparecida Vila Amauri para a Vila Planalto. Outro grupo corresponde aos primeiros gentrificadores ou colonizadores do bairro, composto por funcionários dos serviços públicos ou profissionais de outras áreas que chegaram ao bairro há cerca de vinte anos, após o tombamento: eles compraram lotes de pioneiros iniciando uma lenta vinda de outros habitantes de classe média ou média alta e a paulatina aparição de comércio e restaurantes orientados a uma população externa, elitizando, principalmente, os setores mais bem conectados ao resto da cidade e mais acessíveis de carro. 
Os novos moradores provêm de diversas classes sociais e de diferentes modos de vida. Por uma parte, se encontram imigrantes vindos do nordeste do Brasil ou de outros países, sendo estudantes e pessoas que trabalham no mesmo bairro. Por outro lado, setores mais populares que chegaram das cidades satélites para alugar informalmente nos fundos de lotes, contribuindo para a popularização da Vila.

Podemos concluir que o bairro da Vila Planalto representa um espaço de rotina e transgressão das trajetórias individuais de seus moradores, onde as ruas, praças, bares e mercados, conformam potenciais lugares de engajamentos social e conflito. Apesar das estratégias de elitização, mantêm-se certas transgressões ou ruídos visuais no espaço urbano, conformando os contra-usos que transformam o espaço em lugares de contestação e conflito. As referências que Humberto Giannini (2013) faz sobre os aspectos espaciais e temporais do cotidiano são evidentes no caso de estudo: a rua, o trabalho, a praça e o bar constituem os lugares da experiência comum dos moradores. Esses espaços de rotina e transgressão das trajetórias individuais representam os lugares de engajamento social (CERTEAU, 1996) na Vila Planalto.

\section{Conclusões gerais}

Globalmente, o processo de extração das mais-valias do solo urbano tem sido acelerado e desigual pela rápida mobilidade do capital financeiro investido no mercado imobiliário. Promovido pelas políticas urbanas pró-empresariais e pela falta de terra urbana, muitas cidades experimentam o aumento dos custos da expansão periférica e das longas distâncias do transporte, o que enfatiza a importância do capital espacial do espaço central, principalmente diante dos processos de gentrificação (LEES; SHIN; LÓPEZ, 2015).

Para Lees et al. (2015) o fenômeno da gentrificação é global e se expande de tal forma que os espaços urbanos ao redor do mundo estão cada vez mais sujeitos ao capital internacional e local reinvestido para ser transformados em novos usos que atendam às necessidades dos mais ricos. Assim, a gentrificação tornou-se um processo muito importante no crescimento desigual das cidades e sociedades no mundo.

No contexto do sul global, existem múltiplas gentrificações. Nos casos de latinogentrification (INZULZA, 2012), afetam principalmente em áreas patrimoniais. As trajetórias são afetadas pela ascensão de políticas neoliberais, principalmente 
comportamentos revanchistas no espaço público destinado a sustentar ou estimular a gentrificação. As políticas da gentrificação formam parte de estratégias globais de revitalização urbana, mas existem - na maioria dos casos de gentrificação simbólica padrões locais. Nestes casos, a gentrificação transforma ademais da paisagem construída e da estrutura socioeconômica, a vida cotidiana dos residentes que conseguem permanecer, reinterpretando os sentidos e reapropriando-se dos lugares.

Nos estudos de gentrificação na América latina, Janoschka e Sequera (2014) propõem três fatores relevantes das políticas de gentrificação locais: 1) o papel do Estado na definição das políticas oficiais; 2) o valor simbólico dos espaços enobrecidos; 3) a formalização da economia e a tentativa de disciplinar os espaços (JANOSCHKA; SEQUERA, 2014). Leite (2007) acrescentaria um quarto fator relevante, que seria: 4) a resistência à gentrificação, os contra-usos (LEITE, 2007) da cidade revanchista (SMITH, 2012b).

Diferentes formas de revitalização urbana se relacionam com diferentes tipos de intervenções políticas. Alguns projetos envolvem uma larga escala de reconstrução de bairros completos, outros - como o caso da Vila Planalto - que consideram a conservação urbana de bairros históricos, frequentemente envolvem pequenos capitais que procuram explorar certos nichos de negócios.

Lees et al. (2015) destaca que na literatura recente predomina a discussão sobre a gentrificação residencial, mas outras gentrificações existem, como a comercial, turística e simbólica. Os autores expressam a necessidade de ampliar a discussão sobre as formas de deslocamento. O deslocamento se diferencia segundo: tipo (residencial, comercial, espaço público, raça, classe etc.), escala (global ou local, pequenos projetos ou megaprojetos), condições operacionais (legal ou ilegal), e segundo a quem impacta (residências, trabalho, pequenos negócios, casas coletivas etc.).

Clark (2005) propõe que a gentrificação é um processo de mudança na população de usuários de um espaço urbano, de forma que os novos usuários tem maior status socioeconômico. Os novos usuários mais poderosos iniciam uma transformação no ambiente construído. Para Lees et al. (2015) essa concepção deixaria de fora os conflitos em relação ao direito à cidade. $O$ problema da gentrificação teria a ver menos com um problema conceitual e mais com a necessidade de um campo que aborde as desigualdades sistemáticas das sociedades urbanas onde surge a gentrificação. 
Essas ideias seguem o apontado por Smith (1996), que considera primordial manter uma diferenciação de escalas, entre as individualidades da gentrificação em cidades específicas, bairro ou blocos; e entre o conjunto geral de condições e causas que favorecem o surgimento da gentrificação no mundo ao mesmo tempo. Para Smith, o poder da uma concepção teórica mais geral é aumentado pela flexibilidade que gera a sensibilidade dos detalhes da experiência local, e vice-versa.

Depois do desenvolvimento da análise e da reflexão teórica é possível responder às perguntas de pesquisa que se apresentam no seguinte quadro 7 .

Quadro 7: Resumo das perguntas de pesquisa e suas conclusões.

\begin{tabular}{|c|c|}
\hline Pergunta de pesquisa & Conclusões \\
\hline $\begin{array}{l}\text { 1. Existem limites ao processo } \\
\text { de gentrificação na Vila } \\
\text { Planalto? }\end{array}$ & $\begin{array}{l}\text { Existem potenciais limites ao processo de gentrificação no bairro, } \\
\text { criados pelas apropriações e práticas dos moradores na ocupação do } \\
\text { espaço urbano. Essas fronteiras ou fissuras contra-gentrificadoras } \\
\text { são facilitadas pelas condições espaciais. }\end{array}$ \\
\hline $\begin{array}{l}\text { E. Em que medida a } \\
\text { gentrificação da Vila Planalto } \\
\text { é produto das relações globais } \\
\text { ou locais da cidade? }\end{array}$ & $\begin{array}{l}\text { Apesar das particularidades do caso de estudo, o processo de } \\
\text { gentrificação da Vila Planalto se assemelha a outros casos de } \\
\text { gentrificação simbólica na América Latina, principalmente em } \\
\text { centros históricos. Embora não tenha sido possível estabelecer a } \\
\text { participação de capitais globais no mercado imobiliário do bairro, } \\
\text { as políticas de patrimônio implementadas (UNESCO e IPHAN) são } \\
\text { fundamentais para o desenvolvimento urbano do bairro. }\end{array}$ \\
\hline $\begin{array}{l}\text { 3. Qual é a contribuição das } \\
\text { políticas públicas } \\
\text { implementadas no bairro nas } \\
\text { mudanças físicas e } \\
\text { socioeconômicas? }\end{array}$ & $\begin{array}{l}\text { As políticas públicas são um fator fundamental nas transformações } \\
\text { físicas e sociais da Vila Planalto. Destacam três leis especificas que } \\
\text { determinam pontos de inflexão nas etapas do processo de } \\
\text { gentrificação do bairro. Primeiro, uma etapa de especulação e } \\
\text { expulsão com o tombamento e fixação (1988); segundo, o } \\
\text { encarecimento e a comercialização do espaço com o projeto Vila } \\
\text { Planalto, gastronomia e cultura (2010); e terceiro, a expulsão e o } \\
\text { deslocamento generalizado que pode provocar a entrega das } \\
\text { escrituras dos lotes (2014). }\end{array}$ \\
\hline $\begin{array}{l}\text { 4. De que } \text { modo a } \\
\text { configuração } \\
\text { expressa os processos da } \\
\text { dinâmica urbana? }\end{array}$ & $\begin{array}{l}\text { A configuração expressa a dinâmica urbana em duas escalas. } \\
\text { Primeiro, o nível global de acessibilidade (relação do bairro com a } \\
\text { cidade) se relaciona com o surgimento de um comércio voltado } \\
\text { para usuários externos mais elitizados. Segundo, o nível local de } \\
\text { acessibilidade (relação interna) se relaciona com um comércio }\end{array}$ \\
\hline
\end{tabular}




\begin{tabular}{|c|c|}
\hline & $\begin{array}{l}\text { cotidiano dos moradores menos elitizado. A configuração espacial } \\
\text { demonstra uma forte correlação entre a acessibilidade (integração) e } \\
\text { o os usos comerciais no bairro. }\end{array}$ \\
\hline $\begin{array}{l}\text { 5. Quais são as características } \\
\text { do processo de gentrificação e } \\
\text { como se transformam os } \\
\text { cotidianos do bairro? }\end{array}$ & $\begin{array}{l}\text { A gentrificação na Vila Planalto é um processo silencioso que tem } \\
\text { forte correspondência com as etapas de outros casos no sul global. } \\
\text { Podemos classificar o processo como de gentrificação simbólica. } \\
\text { Os cotidianos dos moradores são transformados principalmente } \\
\text { segundo a idade. O cotidiano dos moradores mais antigos (já } \\
\text { aposentados) se diferencia substancialmente do cotidiano dos novos } \\
\text { moradores, mais jovens (funcionários públicos ou profissionais). O } \\
\text { bairro desenvolveu uma oferta imobiliária, de comércio e serviços } \\
\text { diferenciada segundo a demanda de cada classe social. Quitinetes, } \\
\text { quartos, espaços abertos com atividades mais populares, versus, } \\
\text { apartamentos, casas, e atividades comerciais para rendas altas, } \\
\text { manifestando uma polarizada divisão social-espacial. Diante desses } \\
\text { conflitos, surgem espaços de contestação contra-gentrificados que } \\
\text { sofrem com as tentativas de disciplinamento que procuram eliminar } \\
\text { as fronteiras criadas por grupos de residentes. }\end{array}$ \\
\hline
\end{tabular}

Para concluir nos referimos às hipóteses de investigação. A primeira hipótese afirmava que a Vila Planalto atravessa um processo gentrificação com características locais dentro de um contexto de políticas urbanas globais de revitalização urbana. Após a análise das transformações urbanas do bairro podemos validar parcialmente esta hipótese. Como descrevemos no trabalho, a gentrificação do bairro se dá em uma escala pequena e local, e não foram identificados grandes investimentos de capitais atuando nas transformações físicas. As várias tentativas de modificar a legislação existente para permitir maiores índices de construção e o aumento da altura de gabaritos representam estratégias comuns das administrações locais para aumentar as mais-valias do solo urbano e criar nichos de negócios atrativos para grandes empreendedores. A característica específica da história do bairro e as práticas de seus moradores criam demarcações espaciais e simbólicas que limitam o avance da elitização do espaço. No entanto, essas fronteiras são temporais e virtuais, podendo ser modificados ou eliminados facilmente pelos grupos de poder.

A segunda hipótese propõe que as políticas públicas que intervêm no patrimônio cultural transformam o espaço urbano lugar de consumo segregando e expulsando os moradores de baixa renda. Como resultado da pesquisa podemos afirmar que as 
políticas que atuam sobre o território como um bem cultural foram relevantes nos diferentes momentos de transformação física e social. $O$ tombamento e a fixação previstos dentro de um projeto de reabilitação desenvolvido entre técnicos, acadêmicos e moradores, foram alterados segundo os interesses de políticos e partidos que geraram uma relação clientelista entre governantes e população. A declaratória como patrimônio foi fundamental em consolidar o bairro como um lugar desejável para morar iniciando seu processo de gentrificação ao mesmo tempo em que a lei não foi capaz de preservar as características patrimoniais do bairro, que foi descaracterizado pela especulação imobiliária. Novas leis e decretos têm buscado fomentar o comércio voltado ao turismo e lazer no lugar. A entrega das escrituras, que responde a um antigo desejo dos moradores, pode supervalorizar as propriedades e finalmente provocar a perda do capital espacial e o deslocamento total da população mais pobre.

\section{Limitações e perspectivas futuras}

A principal limitação desta dissertação corresponde ao método de análise hipotético dedutivo e ao estudo de um único caso. Nos aspectos socioeconômicos a maior limitação se deu com a falta de dados demográficos ao longo da história. A comparação entre os Censos de 2000 e 2010 deve ser complementada com um levantamento próprio com base em uma enquete domiciliar socioeconômica. Por causa dos limites de tempo, só foi possível desenvolver um levantamento piloto com 12 residências do acampamento Tamboril, impossibilitando seu uso como dado quantitativo. No entanto, o exercício serviu para conhecer melhor a realidade no interior das casas do acampamento e para aperfeiçoar o questionário como ferramenta de pesquisa.

O estudo dos aspectos configuracionais utilizando a Sintaxe Espacial para explorar a realização de uma análise urbana quantitativa (MEDEIROS; HOLANDA, 2007) apresentou vantagens e limitações nesta investigação. As limitações existem em razão da escala da abordagem (tamanho do recorte), mas as vantagens da ferramenta possibilitaram explorar uma visão configuracional e sua relação com elementos históricos, sociais e econômicos do bairro.

Nos aspectos do modo de vida o trabalho apresentou algumas limitações metodológicas. Primeiro, por causa de minha falta de experiência no desenvolvimento 
da análise etnográfica. Segundo, dentro da investigação etnográfica é necessário realizar observações por um período de tempo prolongado, o que não foi possível nesta pesquisa, em que nos limitamos a alguns meses. Terceiro, restrições e falências na administração do tempo na sistematização da informação não permitiram incorporar todo o material gráfico desenvolvido.

O trabalho, desenvolvido durante quase dois anos e meio, abre várias possibilidades futuras. Destaco duas: primeiramente, existe a possibilidade de continuar a pesquisa acadêmica, aumentando o tamanho do escopo empírico (incorporando uma área maior da cidade na análise de gentrificação, por exemplo considerando a área metropolitana) ou incorporando outros casos de estudos que permitam uma análise comparativa (por exemplo, outros acampamentos de obra em Brasília ou casos internacionais). Em segundo lugar, é importante difundir a informação sobre os alcances da gentrificação para a comunidade, com o fim de conscientizá-la acerca dos possíveis efeitos negativos provocados nos bairros com o deslocamento da população e a perda dos laços de vizinhança.

Seguindo as ideias de Slater (2011), na pesquisa utilizamos como tática analítica situarmos em uma posição de margem, tendo mais preocupação pelo deslocamento e pela exclusão da população de baixos ingressos, e menor atenção nos atributos das classes gentrificadoras mais acomodadas. Com isto foi possível reconhecer que os espaços urbanos não são as cidades ideais, onde as populações convivem em harmonia no espaço público. Ao contrário, os espaços públicos, são hoje, o espelho das desigualdades e locais de expressão dos conflitos sociais. Para finalizar, destacamos a frase final do livro do Rogério Proença Leite:

\footnotetext{
(...) não são os ares de uma cidade enobrecida que libertam, mas as formas cotidianas de apropriação política dos lugares, que publicizam e politizam as diferenças, atribuindo sentido e qualificando os espaços da cidade como espaços públicos. (LEITE, 2007, p. 318)
}

Assim, apesar das estratégias de elitização, mantêm-se certas transgressões ou ruídos visuais no espaço urbano, conformando os contra-usos que transformam o espaço em lugares de contestação e conflito. 


\section{BIBLIOGRAFIA}

AGUIAR, D. Urbanidade e qualidade da cidade. In: Qualidades do lugar e cultura contemporânea. Controvérsias e ressonâncias em coletivos urbanos. Rio de Janeiro: FAU, PROARQ, UFRJ, 2012. p. 119-130.

BARROS, A. P.; MEDEIROS, V.; MORAIS, M. da P. A configuração espacial para o diagnóstico dos assentamentos precários no brasil. In: $33^{\circ}$ Encontro Anual da ANPOCS, 0, Anais...2009.

BIDOU-ZACHARIASEN, C. (Coord.) . De volta a cidade. dos processo de gentrificação às políticas de "revitalização" dos centros urbanos. São Paulo: Ed. Annablume, 2006.

BOURDIEU, P. Sociología y cultura. D.F., México: Editorial Grijalbo, S.A., 1990.

BOURDIN, A. A questão local. Rio de Janeiro: Lamparina editora, 2001.

BRANDÃO, V. B. Espaço urbano $x$ apropriação social: um estudo de caso dos espaços públicos abertos de Taguatinga. 2003. Universidade de Brasilia, 2003.

BRENNER, N. What is critical urban theory? City, v. 13, n² 2-3, p. 198-207, 2009.

CARVALHO, C. S.; ROSSBACH, A. O estatuto da cidade: comentado. São Paulo: Ministério das Cidades, 2010.

CASGRAIN, A.; JANOSCHKA, M. Gentrificación y resistencia en las ciudades latinoamericanas el ejemplo de Santiago de Chile. Andamios, v. 10, p. 19-44, 2013.

CASTEllS, M. A questão urbana. 3. ed. ed. São Paulo: Editora Paz e terra S.A, 2006.

CERTEAU, M. de. La invención de lo cotidiano. i. Artes de hacer. 1. ed. ed. México, D.F.: Universidad Iberoamericana, 1996.

CERTEAU, M. de; GIARD, L.; MAYOL, P. A invenção do cotidiano. ii. Morar, cozinhar. 8. ed. ed. Petrópolis, RJ: Editora Vozes, 2008.

CHECA-ARTASU, M. M. Gentrificación y Cultura: algunas reflexiones. Revista Bibliográfica de Geografía y Ciencias Sociales, v. XVI, n. 1138-9796, 2011.

CHIARADIA, A.; HILLIER, B.; BARNES, Y.; SCHAWANDER, C. Residential Property Value Patterns in London. Space Syntax spatial Analysis. (D. KOCH, L. MARCUS, J. STEEN, Eds.) In: 7th International Space Syntax Symposium, Stockholm. Anais... Stockholm: 2009. 
CLARK, E. The order and simplicity of gentrification - a political challenge. In: Gentrification in a Global Context: The new urban colonialism. Oxon: Routledge, 2005. p. 256-264.

COÊLHO, C. M. Changements dans les coulisses de Brasília. Les ambigïtés du processus de maintien de Vila Planalto (1956-2006). 2007. École des Hautes Études en Sciences Sociales, 2007.

COÊLHO, C. M. Utopias urbanas: o caso de Brasília e Vila Planalto. Cronos, v. 9, p. $65-75,2008$.

COÊLHO, C. M. Espacios de historia, espacios de memoria: Vila Planalto en los bastidores de Brasília. In: III Congreso Nacional de Ciencias Sociales, Ciudad de México 2011, Ciudad de México. Anais... Ciudad de México: 2011.

COSTA, L. Brasília 57-85; do plano-piloto ao Plano Piloto. Brasília, 1985.

DALTON, N. S. C. Configuration and neighbourhood: is place measurable. Space syntax and spatial cognition, SFB TR8 Spatial ... cognition, SFB TR8 Spatial. p. 12, $2006 . \quad$ Disponível em: $<$ http://scholar.google.com/scholar?hl=en\&btnG=Search\&q=intitle:Configuration + and +Neighbourhood+:+Is+Place+Measurable+?\#0>. Acesso em: 22 jul. 2013.

DÍAZ, I. Gentrificación y clase social. La Producción del gentrificador. Departamento de Geografía Humana. Universidad de Sevilla, 2004. Disponível em: <http://medcontent.metapress.com/index/A65RM03P4874243N.pdf > . Acesso em: 20 jul. 2013.

DRAKE, S. C.; CAYTON, H. R. Black Metropolis: A Study of Negro Life in a Northern City. Chicago: University of Chicago Press, 1993.

DUBOIS, W. E. B. The Philadelphia Negro. A Social Study. New York: Schocken Books Inc., 1899.

FERNANDES, E. La construcción del "Derecho a la ciudad" en Brasil. In: La ciudad y el derecho. 2007. p. 494-518.

GASIC, I. Gentrificación en el pericentro metropolitano del gran Santiago. 2013. Universidad de Chile, 2013.

GIANNINI, H. La "reflexión" cotidiana. Hacia una arqueología de la experiencia. 2. ed. Santiago: Ediciones UDP, 2013.

GIL, A. C. Métodos e técnicas de pesquisa social. 6. ed. ed. São Paulo: Editora Atlas S.A., 2008.

GLASS, R. London: aspects of change. 1. ed. Londres: McGibbon and Kee, 1964. 
HANNERZ, U. Exploración de la ciudad. hacia uma antropologia urbana. 1 ed. ed. Ciudad de México: Fondo de Cultura Económica, 1986.

HANSON, J.; HILLIER, B. The social logic of space. 1. ed. Cambridge: Cambridge Univesity Press, 1984.

HARVEY, D. The urban experience. Oxford: Basil Blackwell, 1991.

HARVEY, D. A produção capitalista do espaço. São Paulo: Annablume, 2005.

HARVEY, D. Neoliberalism as Creative Destruction. The Annals of the American Academy of Political and Social Science, v. 610, n. 1, p. 21-44, 1 mar. 2007. Disponível em: <http://ann.sagepub.com/cgi/doi/10.1177/0002716206296780>. Acesso em: 24 maio. 2013.

HARVEY, D. Ciudades rebeldes. del derecho de la ciudad a la revolución urbana. Madrid: Akal, S.A., 2012.

HILLIER, B. The Architecture of the Urban Object. Ekistics: the problems and science of human settlements., v. 56, p. 5-21, 1989.

HILLIER, B. Space is the machine. a configurational theory of architecture. London: UCL, 2007.

HILLIER, B.; NETTO, V. Society seen through the prism of space: outline of a theory of society and space. In: $3^{\circ}$ Space Syntax Symposium, Atlanta. Anais... Atlanta: 2001. HOFFMANN, O. Espacios y movilidad de la gente negra en el Pacífico Sur colombiano: ¿hacia la construcción de una "sociedad regional”? Estudos AfroAsiáticos, v. 3, n. 1, p. 43-74, 2002.

HOLANDA, F. de. O espaço de exceção. Brasília: Editora Universidade de Brasília, 2002.

HOLANDA, F. de. Sociological Architecture. A Particular Way Of Looking At Places. The Journal of Space Syntax, v. 1, n. December, p. 337-355, 2010a.

HOLANDA, F. de. Urbanidade: arquitetônica e social. In: I Encontro Nacional Nacional Associação Nacional de Pesquisa e Pós-graduação em Arquitetura e Urbanismo., Anais...2010b.

HOLANDA, F. de. Brasília - cidade moderna, cidade eterna. Brasília: FAU UnB, 2010c.

HOLANDA, F. de. Dez mandamentos da arquitetura. Brasília: FRBH, 2013.

HOLANDA, F. de. (Org.). Ordem e desordem - arquitetura e vida social. Brasília: FRBH, 2012. 
HOLANDA, F. de (Org.). Arquitetura \& urbanidade. Brasília: Ed. FRBH, 2001.

INZULZA, J. "Latino Gentrification"? Focusing on Physical and Socioeconomic Patterns of Change in Latin American Inner Cities. Urban Studies, v. 49, n. 20852107, 2012.

JANOSCHKA, M.; SEQUERA, J. Procesos de gentrificación y desplazamiento en América Latina, una perspectiva comparativista. In: Desafíos metropolitanos. Un diálogo entre Europa y América Latina. Madrid: Catarata, 2014. p. 82-104.

JANOSCHKA, M.; SEQUERA, J.; SALINAS, L. Gentrification in Spain and Latin America - a Critical Dialogue. International Journal of Urban and Regional Research, p. n/a-n/a, 8 ago. 2013. Disponível em: $<$ http://doi.wiley.com/10.1111/1468-2427.12030>. Acesso em: 13 jan. 2014.

KOHLSDORF, M. E. As imagens de Brasília. In: Brasília, ideologia e realidade: espaço urbano em questão. $2^{\circ}$ ed. ed. Brasília: Editora Universidade de Brasília, 2010a. p. 239-284.

KOHLSDORF, M. E. Estudo comparativo de desempenho topoceptivo entre localidades do Distrito Federal, 2010b. .

LAURIANO, W. Gentrificação: estratégias de enobrecimento do solo urbano. dos tijolos de barro no subúrbio paulistano aos blocos de Brasília. 2013. Universidade de Brasília, 2013.

LAURIANO, W. Gentrificação da cidade modernista: Brasília. Cadernos das Metrópoles, v. 17, n. 33, p. 155-178, 2015.

LEES, L.; SHIN, H. B.; LÓPEZ, E. Conclusion: global gentrifications. In: Global Gentrifications. Uneven development and displacement. Bristol: Policy Press, 2015. p. 441-452.

LEES, L.; SLATER, T.; WYLY, E. Gentrification. New York: Routledge, 2008.

LEES, L.; SLATER, T.; WYLY, E. The gentrification reader. New York: Routledge, 2010.

LEFEBVRE, H. El derecho a la ciudad. $1^{\circ}$ Ed. ed. Barcelona: Ediciones Península, 1969.

LEITE, R. P. Contra-usos e espaço público: notas sobre a construção social dos lugares na Manguetown. Revista Brasileira de Ciências Sociais, v. 17, p. 115-172, 2002. Disponível em: <http://www.scielo.br/pdf/rbcsoc/v17n49/a08v1749.pdf>. Acesso em: 11 maio. 2014. 
LEITE, R. P. Contra-usos da cidade lugares e espaço público na experiência urbana contemporânea. 2 ed. Campinas, SP: Editora UNICAMP, 2007.

LESS, L. Gentrification and Social Mixing: Towards an Inclusive Urban Renaissance? Urban Studies, v. 45, n. 12, p. 2449-2470, 1 nov. 2008. Disponível em: $<$ http://usj.sagepub.com/cgi/doi/10.1177/0042098008097099>. Acesso em: 22 maio. 2013.

LÉVY, J. Os novos espaços da mobilidade. In: Les Territoires de la Mobilité. Paris: Presses Universitaires de France, 2000.

LEY, D. Reply: The Rent Gap Revisited. Annals of the Association of American Geographers, v. 77, p. 465-468, 1987.

LIMA, J. J. F. Aspectos políticos e espaciais das locações na malha urbana: o exemplo de Belém, no Brasil. In: Space Syntax Second InternationalSymposium, Brasília. Anais... Brasília: 1999.

LÓPEZ, E. Destrucción creativa y explotación de brecha de renta: discutiendo la renovación urbana del pericentro sur poniente de Santiago de Chile entre 1990 y 2005. Scipta Nova. Revista electrónica de geografía y ciencias sociales., v. XII, n. 11389788, p. 1-19, 2008.

LÓPEZ, E. Urban entrepreneurialism and creative destruction: a case-study of the urban renewal strategy in the peri-centre of Santiago de chile, 1990-2005. 2009. University College London, 2009.

LÓPEZ, E. Gentrification by Ground Rent Dispossession: The Shadows Cast by Large-Scale Urban Renewal in Santiago de Chile. International Journal of Urban and Regional Research, v. 35, n. March, p. no-no, 28 jul. 2010. Disponível em: <http://doi.wiley.com/10.1111/j.1468-2427.2010.00961.x>. Acesso em: 13 jan. 2014.

LÓPEZ, E. Gentrificación y desplazamiento en América Latina: tres factores causales concatenados. In: Contested Cities, working papers. Santiago, 2015.

LÓPEZ, E.; GASIC, I.; MEZA, D. Urbanismo pro-empresarial en Chile: políticas y planificación de la producción residencial en altura en el pericentro del Gran Santiago. Revista INVI, v. 27, p. 75-114, 2012.

MARCUSE, P. From critical urban theory to the right to the city. City, v. 13, n 2-3, p. 185-197, 2009.

MARCUSE, P.; VAN KEMPEN, R. Globalizing cities. a new spatial order? 1 ed. Oxford: Blackwell Publishing Ltd., 2000. 
MATTHEWS, J.; TURNBULL, G. Neighborhood street layout and property value: the interaction of accessibility and land use mix. The journal of real estate finance and ... $\quad$ v. $35, \quad$ p. 111-141, 2007 . Disponível em: $<$ http://link.springer.com/article/10.1007/s11146-007-9035-9>. Acesso em: 24 jul. 2013.

MEDEIROS, V. Urbis brasiliae ou sobre cidades do brasil: inserindo assentamentos urbanos do país em investigações configuracionais comparativas. 2006. Universidade de Brasília, 2006.

MEDEIROS, V. Urbis brasiliae: o labirinto das cidades brasileiras. Brasília: Editora Universidade de Brasília, 2013.

MEDEIROS, V.; HOLANDA, F. de. Da colcha de retalhos ao espaço de fragmentação: a perspectiva configuracional em cidades brasileiras. In: XII ENCONTRO DA ASSOCIAÇÃO NACIONAL DE PÓS-GRADUAÇÃO E PESQUISA EM PLANEJAMENTO URBANO E REGIONAL, Belém. Anais... Belém: 2007.

MONTEIRO, C.; CAVALCANTE, R. A Face Noturna da Cidade: dinâmica sócio espacial, morfologia e segurança das atividades noturnas no bairro de Boa Viagem, Recife. In: Teorias e práticas na Arquitetura e na Cidade Contemporâneas, Natal, Brasil. Anais... Natal, Brasil: 2012.

MOSCIARO, M. Gentrificação na lapa ? um estudo sobre mudanças na área central do rio de janeiro. 2012. Universidade Federal do Rio de Janeiro, 2012.

MURILLO, J. La investigación etnográficaVasa, 2011. .

NOBRE, E. A. Políticas urbanas para o centro de são paulo: Renovação ou reabilitação? Avaliação das propostas da prefeitura do município de São Paulo de 1970 a 2004. Pós, v. 16, n. 25, p. 214 - 231, 2009.

PARK, R. E. La ciudad y otros ensayos de ecología urbana. 1 ed. ed. Barcelona: Ediciones del Serbal, 1999.

PAVIANI, A. (Org.). A conquista da cidade. movimentos urbanos em brasília. Brasília: Editora Universidade de Brasília, 1991.

PAVIANI, A. (Org.). Brasília: moradia e exclusão. Brasília: Editora Universidade de Brasília, 1996.

RIBEIRO, G. L. O capital da esperança: a experiência dos trabalhadores na construção de Brasília. Brasília: Editora Universidade de Brasília, 2008. 
RIBEIRO, G. L. Acampamento de grande projeto: uma forma de imobilização da força de trabalho pela moradia. In: A conquista da cidade: movimentos populares em Brasília. $2^{\circ}$ ed. Brasília: Editora Universidade de Brasília, 2010. p. 25-82.

RIBEIRO, M. S. Habitar, trabalhar, recrear e circular: possibilidades e limitações nas superquadras de Brasília. 2013. Universidade de Brasília, 2013.

RIBEIRO, S. B. Brasília: memória, cidadania e gestão do patrimônio cultural. São Paulo: Ed. Annablume, 2005.

RODRIGUES, W. Urbanidade e novos estilos de vida. Sociologia - Problemas e Práticas, v. 12, p. 91-107, 1992.

RODRIGUES, W. Cidade em transição. nobilitação urbana, estilos de vida e reurbanização em Lisboa. 1. ed. Oeiras: Celta Editora, 2010.

RODRIGUEZ, C.; GRIFFITHS, S.; LIMA SAKR, F.; HILLIER, B. The relationship of spatial configuration and socio-economic conditions in São Paulo, Brazil. In: Eighth International Space Syntax Symposium, Santiago. Anais... Santiago: 2012.

SANTOS, C. N. Como e quando pode um arquiteto virar um antropólogo. In: O desafio da cidade: novas perspectivas da antropologia brasileira. Rio de Janeiro: Editora Campus, 1980.

SCHLACK, E.; TURNBULL, N. Capitalizando lugares auténticos. Artistas y emprendimientos en la regeneración urbana. ARQ, v. 79, p. 28-36, 2011.

SECRETARIA DE TURISMO DO Distrito FEDERAL. Projeto Vila Planalto: Gastronomia e Cultura., Brasília: GDF, 2010.

SEDUMA. A Vila Planalto em Proposta. In: $1^{\circ}$ Seminário SEDUMA, Brasília. Anais... Brasília: 2008.

SEDUMA - CODEPLAN. Levantamento Domiciliar Socioeconômico. Vila Planalto, 2009.

SEQUERA, J. Las políticas de gentrificación en la ciudad neoliberal. Nuevas clases medias, producción cultural y gestión del espacio público. El caso de Lavapiés en el centro historico de Madrid. 2013. Universidad Complutense de Madrid, 2013.

SLATER, T. Gentrification of the City. The New Blackwell Companion to the City, p. 571-585, 2011.

SMITH, N. Toward a Theory of Gentrification A Back to the City Movement by Capital, not People. Journal of the American Planning Association, v. 45, p. 538$548,1979$. 
SMITH, N. Gentrification and the Rent Gap. Annals of the Association of the American Geographers, v. 77, p. 462-465, 1987.

SMITH, N. Gentrifying theory. Scottish Geographical Magazine, v. 111, n. 2, p. 124-126, jan. $1995 . \quad$ Disponível em: $<$ http://www.tandfonline.com/doi/abs/10.1080/00369229518736951>. Acesso em: 13 jan. 2014.

SMITH, N. The new urban frontier. 1. ed. New York: Routledge, 1996.

SMITH, N. A gentrificação generalizada: de uma anomalia local à "regeneração" urbana como estratégia urbana global. In: De volta à cidade. Dos processos de gentrificação às políticas de "revitalização" dos centros urbanos. $1^{\circ}$. ed. São Paulo: Editora Annablume, 2006. p. 59-88.

SMITH, N. Entrevista a Neil Smith. Boletim Campineiro de Geografia, v. 2, p. 358$363,2012 a$.

SMITH, N. La nueva frontera urbana. ciudad revanchista y gentrificação. 1. ed. Madrid: Traficantes de Sueños, 2012 b.

SWYNGEDOUW, E. The Antinomies of the Postpolitical City. International Journal of Urban and Regional Research, v. 33, p. 601-620, 2009.

TRUJILlO, A. Metodologia da pesquisa científica. 1 ed. ed. São Paulo: McGrawHill, 1982.

VELHO, G. (org.). O desafio da cidade: novas perspectivas da antropologia brasileira. Rio de Janeiro: Editora Campus, 1980.

VELHO, G.; MAGGIE, Y. O Barata Ribeiro 200 com pós-escrito de Yvonne Maggie e comentários de Anthony Leeds. Anuário Antropológico, v. 38, n. 2, p. 19-36, 2012. VIERIA, M. Distinção, cultura de consumo e gentrificação: o centro cultural banco do brasil e o mercado de bens simbólicos. 2006. Universidade de Brasília, 2006.

WIRTH, L. El urbanismo como modo de vida. Bifurcaciones, v. 2, 2005.

ZARUR, S. A sobrevivência da vila planalto: de acampamento pioneiro a bairro histórico de Brasília. 1991. Universidade de Brasília, 1991.

ZARUR, S. Vila Planalto: um caso de resistência popular. In: Brasília, moradia e exclusão. Brasília: Editora Universidade de Brasília, 1996. p. 81-113.

ZDRAHALOVA, J. Meaning of space in the gentrified part of Prague. WS, v. 23, p. 9, 2000 . 


\section{ANEXOS}

Anexo 1 - Questionário enquete domiciliar

Anexo 2 - Lista cronológica completa da legislação urbanística

Anexo 3 - Lista cronológica completa dos projetos de lei

Anexo 4 - Lista completa dos processos jurídicos e documentos legais

Anexo 5 - Seleção de entrevistas transcritas

Anexo 6 - Experiência etnográfica 


\begin{tabular}{|l|l|l|}
\hline \multicolumn{3}{|c|}{ Levantamento domiciliar para residentes da Vila Planalto 2015} \\
\hline № Folio: 002 & Nome do entrevistador: MATIAS & Data: 23/03/15 \\
\hline \hline Perguntas de filtro: & Condições a cumprir: \\
\hline 1. Mora gente nesta casa? & a) Domicílio particular permanentemente ocupado \\
\hline 2. Está presente o proprietário ou locatário? & b) Pode responder proprietário, locatário, cônjuge ou filho +18. \\
\hline 3. Há quanto tempo mora aqui? & c) Ocupar o domicílio há pelo menos 1 ano. \\
\hline
\end{tabular}

\begin{tabular}{|c|c|c|c|c|c|c|c|}
\hline $\begin{array}{c}\text { Acampamento } \\
\text { /Quarteirão }\end{array}$ & Nome da rua & № Lote & $\begin{array}{c}\text { № Casa- } \\
\text { Apto. }\end{array}$ & $\begin{array}{c}\text { Rua de } \\
\text { referência }\end{array}$ & $\begin{array}{c}\text { Proprie- } \\
\text { tário }\end{array}$ & $\begin{array}{c}\text { Aluguel } \\
\text { casa }\end{array}$ & $\begin{array}{c}\text { Aluguel } \\
\text { apto. }\end{array}$ \\
\hline TAMBORIL / A & RUA 4 & & 08 & & $\mathrm{X}$ & & \\
\hline
\end{tabular}

\section{PARTE I. Características do Domicílio}

\begin{tabular}{|c|c|c|c|c|c|c|c|c|}
\hline \multicolumn{9}{|c|}{ P.1. Este domicílio é: } \\
\hline a) Próprio já pago & \multicolumn{2}{|c|}{$\begin{array}{l}\text { b) Próprio ainda } \\
\text { pagando }\end{array}$} & \multicolumn{2}{|c|}{$\begin{array}{l}\text { c) Cedido por } \\
\text { empregador }\end{array}$} & \multicolumn{3}{|c|}{$\begin{array}{l}\text { d) Cedido de outra } \\
\text { condição X }\end{array}$} & $\begin{array}{l}\text { e) Outra condição. } \\
\text { Qual? }\end{array}$ \\
\hline \multicolumn{7}{|c|}{ P.2. Em que ano foi construída esta casa ou apartamento aproximadamente? } & \multicolumn{2}{|l|}{30 ANOS } \\
\hline \multicolumn{7}{|c|}{ P.3. Quantos banheiros de uso exclusivo dos moradores este domicílio tem? } & \multicolumn{2}{|l|}{3} \\
\hline \multicolumn{9}{|c|}{ P.4. Quantos veículos existem neste domicílio? (№) } \\
\hline \multirow[t]{2}{*}{ a) Automóvel } & b) Utilitário & c) Carga & d) Moto & \multicolumn{2}{|c|}{ e) Bicicleta } & \multicolumn{2}{|c|}{ f) Carroça } & \multirow[t]{2}{*}{ g) Outro. Qual? } \\
\hline & & & & 1 & & & & \\
\hline
\end{tabular}

\begin{tabular}{|l|l|l|l|l|}
\hline \multicolumn{5}{|l|}{ P.5. Quantos serviços tem contratado? (№) } \\
\hline a) Internet & b) TV por assinatura & c) Assinatura jornais & d) Assinatura revistas & e) Outros. Qual? \\
\hline $\mathrm{X}$ & $\mathrm{X}$ & & & \\
\hline
\end{tabular}

P.6. Tem algum empregado trabalhando na sua casa?
a) $\mathrm{Sim}$
b) Não X
c) Quantos?

\section{PARTE II. Caraterísticas dos Moradores}

\begin{tabular}{|l|l|}
\hline P.7. Há quantos anos o seu grupo familiar mora neste domicílio? (№) & + DE 30 \\
\hline P.8. Há quantos anos o seu grupo familiar reside na Vila Planalto? (№) & +30 \\
\hline P.9. Há quantos anos reside no Distrito Federal? (№) & 1979 \\
\hline P.10. Em que lugar morou antes de chegar na Vila? (Bairro/Município-RA/Estado) & TAGUATINGA NORTE \\
\hline
\end{tabular}

P.11. Listado de moradores: (incluir pessoa que responde)

\begin{tabular}{|c|c|c|c|c|c|c|c|}
\hline № & a) Nome & $\begin{array}{l}\text { b) } \\
\text { Sexo }\end{array}$ & c) Idade & $\begin{array}{l}\text { d) Parentesco } \\
\text { com responsável }\end{array}$ & $\begin{array}{l}\text { e) Lugar trabalho } \\
\text { ou estudo }\end{array}$ & $\begin{array}{l}\text { f) Nível de } \\
\text { escolaridade }\end{array}$ & $\begin{array}{l}\text { g) Situação } \\
\text { laboral atual }\end{array}$ \\
\hline 1 & ANGELICA & $\mathrm{F}$ & 71 & 1 & EM CASA & 10 & 3 \\
\hline 2 & MARIA & $\mathrm{F}$ & 48 & 3 & PLANO PILOTO & 7 & 2 \\
\hline 3 & PEDRO & $\mathrm{M}$ & 35 & 11 & VILA PLANALTO & 10 & 2 \\
\hline 4 & MARIA & $\mathrm{F}$ & 23 & 7 & CULTURA ING. & 7 & 8 \\
\hline 5 & & & & & & & \\
\hline 6 & & & & & & & \\
\hline 7 & & & & & & & \\
\hline 8 & & & & & & & \\
\hline 9 & & & & & & & \\
\hline 10 & & & & & & & \\
\hline
\end{tabular}
b) Sexo ou gênero
M. Masculino
F. Feminino

\begin{tabular}{|l|l|l|}
\hline d) Parentesco com o responsável pelo domicílio \\
\hline Código resposta & Código resposta & Código resposta \\
\hline 1. Pessoa responsável & 2. Cônjuge ou companheira(o) & 3. Filha(o) dos responsáveis \\
\hline 4. Genro ou nora & 5. Pai, mãe, padrasto ou madrasta & 6. Sogra(o) \\
\hline 7. Neta(o) & 8. Bisneta(o) & 9. Irmã ou irmão \\
\hline 10. Avô ou Avó & 11. Outro parente & 12. Agregada(o) \\
\hline
\end{tabular}




\begin{tabular}{|l|l|l|}
\hline f) Nível de escolaridade & 2. Sabe ler e escrever & 3. Alfabetização de adultos \\
\hline 1. Não sabe ler e escrever & 5. Jardim I-II ou Pré-escolar & 6. Fundamental incompleto \\
\hline 4. Maternal e Creche & 8. Médio incompleto & 9. Médio completo \\
\hline 7. Fundamental completo & 11. Superior completo & 12. Especialização \\
\hline 10. Superior incompleto & 14. Doutorado & 15. Não sabe \\
\hline 13. Mestrado &
\end{tabular}

\begin{tabular}{|l|l|}
\hline g) Situação laboral atual $(+10$ anos $)$ \\
\hline 1. Sem atividade & 2. Com trabalho remunerado \\
\hline 3. Aposentado & 4. Aposentado trabalhando \\
\hline 5. Pensionista & 6. Trabalho do lar \\
\hline 7. Desempregado & 8. Estudante \\
\hline 9. Voluntário & 10. Menor de 10 anos \\
\hline
\end{tabular}

P.12. A sua cor ou raça é:
a) Branca
b) Preta X
c) Amarela
d) Parda
e) Indígena

\begin{tabular}{|l|l|l}
\hline P.13. Qual é o tempo total de deslocamento entre seu domicílio e suas atividades cotidianas? & 1 HORA \\
\hline
\end{tabular}

\begin{tabular}{|l|l|l|l|l|l|l|l|}
\hline \multicolumn{2}{|l|}{ P.14. Qual é o modo de deslocamento entre seu domicílio e suas atividades cotidianas? } \\
\hline a) A pé & b) Bicicleta & c) Moto & d) Carro & e) Carona & f) Ônibus & g) Taxi & h) Outros. Qual? \\
\hline & & & & & X & & \\
\hline
\end{tabular}

P.15. Que lugar é o mais utilizado para o lazer?

\begin{tabular}{|l|l|}
\hline a) A própria residência X & b) Espaços comuns (condomínios) \\
\hline c) Outras residências do bairro & d) Outras residências fora do bairro \\
\hline $\begin{array}{l}\text { e) Espaços públicos abertos no bairro (praças, } \\
\text { parques, bares de calçada) }\end{array}$ & f) Espaços públicos fora do bairro \\
\hline $\begin{array}{l}\text { g) Locais irrestritos fechados (restaurantes, cinemas, } \\
\text { teatro, shopping) X }\end{array}$ & h) Locais de acesso restritos (clubes, associações) \\
\hline i) Outro. Qual? BRASíLIA MOTO NAUTICA & \\
\hline
\end{tabular}

P.16. Suas compras costumam ser realizadas dentro do bairro? Em alguma loja em particular?
a) $\operatorname{Sim} X$
b) Não
c) Qual? ARMAZEM DE GERALDO

\section{PARTE III. Grau de Instrução, Trabalho e Renda}

\begin{tabular}{|l|l|l|l|l|l|}
\hline P.17 Qual é sua ocupação atual? & $X$ & b) Empregado com CT & c) Empregado sem CT & \\
\hline a) Não trabalha & & e) Serviço público-militar & & f) Autônomo & \\
\hline d) Temporário & & h) Estagiário & & i) Cargo comissionado & \\
\hline g) Empregador & & k) Outro. Qual? & & \\
\hline j) Trabalho no remunerado &
\end{tabular}

\begin{tabular}{|l|l|l|}
\hline \multicolumn{3}{|l|}{ P.18. Algum integrante do domicílio recebe alguma ajuda ou bolsa (subsídio) por parte do Estado? } \\
\hline a) Sim & b) Não X & c) Qual? \\
\hline
\end{tabular}

\begin{tabular}{|l|l}
\hline P.20. Qual foi seu rendimento total do mês passado, incluindo salário e outras fontes de renda? (R\$) & $1.000,00$
\end{tabular}

\begin{tabular}{|lll}
\hline P.21. Considerando todos os ingressos do lar (incluindo salários, bolsas, aposentadorias, alugueis e & $15.000,00$
\end{tabular} outras rendas), qual foi o valor aproximado da renda familiar mensal no último mês? (R\$) 


\section{Situação Fundiária Atual}

\begin{tabular}{|l|l|l|l|l|}
\hline P.22. Que tipo documento de posse do imóvel possui? & e) Outro. Qual? \\
\hline $\begin{array}{l}\text { a) Não é } \\
\text { proprietário }\end{array}$ & $\begin{array}{l}\text { b) Concessão de uso } \\
\mathrm{X}\end{array}$ & $\begin{array}{l}\text { c) Contrato de } \\
\text { compra-venda }\end{array}$ & $\begin{array}{l}\text { d) Título de } \\
\text { domínio }\end{array}$ \\
\begin{tabular}{|l|l|l|l|}
\hline P.23. Como adquiriu o imóvel? & b) Recebeu do \\
a) Não é \\
proprietário
\end{tabular} & $\begin{array}{l}\text { c) Recebeu de } \\
\text { herança }\end{array}$ & $\begin{array}{l}\text { d) Comprou de } \\
\text { terceiros }\end{array}$ & e) Outro. Qual? \\
\hline
\end{tabular}

\begin{tabular}{|l|l|}
\hline P.24. Qual foi o preço aproximado que pagou por este imóvel? (R\$) & 0,00 \\
\hline P.25. Se aluga. Qual é o valor aproximado do aluguel por este imóvel? (R\$) & \\
\hline
\end{tabular}

\begin{tabular}{|c|c|c|c|}
\hline P.26. Est & u IPTU r & & \\
\hline a) $\operatorname{Sim} X$ & b) Não & c) Quanto? $\mathrm{R} \$ 500,00$ & d) Não sabe \\
\hline
\end{tabular}

\section{Situação Imobiliária Atual (para proprietários residentes há mais de 5 anos)}

P.27. Nos últimos 12 meses têm sido publicados avisos ou cartazes para vender ou alugar esta propriedade?

\begin{tabular}{|l|l|l}
\hline a) Sim & b) Não X & c) Que tipo? (casa, apartamento, quitinete, cômodo, loja) \\
\hline & & \\
\hline
\end{tabular}

P.28. Nos últimos 12 meses tem recebido visitas de pessoas ou corretores de imóveis interessados em comprar ou alugar esta propriedade?

\begin{tabular}{|l|l|l|}
\hline a) $\operatorname{Sim} X$ & b) Não & c) Quantos? 2 OU 3 \\
\hline
\end{tabular}

P.29. Nos últimos 12 meses tem recebido alguma oferta concreta para comprar ou alugar esta propriedade?

\begin{tabular}{|l|l|l|}
\hline a) Sim & b) Não X & c) Que valor? \\
\hline P.30. De alguma empresa ou pessoa particular? & c) Outro. Qual? \\
\hline a) Empresa & b) Particular & c) Out
\end{tabular}

P.31. Sabe de algum vizinho deste quarteirão que tenha vendido ou mantenha conversações para vender sua propriedade?
a) $\mathrm{Sim}$
b) Não X

P.32. 0 preço desta propriedade, hoje comparado há 5 anos, você acredita que:
a) aumentou muito
b) aumentou algo $\mathrm{X}$
c) está igual
d) diminuiu algo
e) diminui muito

\begin{tabular}{|c|c|c|c|c|c|}
\hline \multicolumn{6}{|l|}{ P.33. Por que você pensa que isto acontece? } \\
\hline $\begin{array}{l}\text { a) Infraestrutura pública (pavimentação } \\
\text { de vias, pontos de ônibus, esgoto, etc.) }\end{array}$ & $\operatorname{Sim} X$ & Não & b) Comércio, restaurantes e serviços & Sim & $\begin{array}{l}\text { Não } \\
X\end{array}$ \\
\hline c) Edifícios de apartamentos-quitinetes & $\operatorname{Sim} X$ & Não & d) Outro. Qual? ENTREGA DE ESCRIT & & \\
\hline
\end{tabular}

\section{Preferências Habitacionais Futuras (para proprietários residentes há mais de 5 anos)}

P.34. Pensando em seus planos de vida nos próximos cinco anos, com que frase se identifica mais?

\begin{tabular}{|l|l|}
\hline a) Não me interessa nada mudar de casa nem de bairro & $\mathrm{X}$ \\
\hline b) Me interessaria muito mudar de casa ou de bairro & \\
\hline c) Me interessa mas não tenho o dinheiro & \\
\hline d) Só me interessaria caso me ofereçam um bom preço por minha propriedade & \\
\hline e) Outro. Qual? & \\
\hline
\end{tabular}

\section{\begin{tabular}{|l|l|l} 
P.35. Se hoje você vendesse sua propriedade, por que valor acredita que seria? (R\$) & N/R
\end{tabular}}

P.36. Qual seria o valor máximo que gastaria em comprar ou alugar outra propriedade?
a) Comprar
b) Alugar
c) Valor(R\$) 1.500,00 X MES 


\begin{tabular}{|c|c|c|c|c|}
\hline \multicolumn{5}{|c|}{ P.37. Em caso de comprar ou alugar, você preferiria? } \\
\hline a) $X$ & Casa & $\mathrm{v} / \mathrm{s}$ & b) $\mathrm{X}$ & Apartamento \\
\hline a) & Nova(o) & $\mathrm{v} / \mathrm{s}$ & b) & Usada(o) \\
\hline a) $\mathrm{X}$ & Isolada em lote & $\mathrm{v} / \mathrm{s}$ & b) & Condomínio \\
\hline a) & Casa grande com quintal pequeno & $\mathrm{v} / \mathrm{s}$ & b) $X$ & Casa pequena com quintal grande \\
\hline a) & Apto. pequeno bem localizado & $\mathrm{v} / \mathrm{s}$ & b) & Apto. grande em qualquer setor \\
\hline
\end{tabular}

P.38. Em caso de comprar ou alugar, que lugar preferiria para viver?

\begin{tabular}{|l|l|l|l|l}
$\begin{array}{l}\text { a) Na mesma Vila } \\
\text { Planalto X }\end{array}$ & b) Num setor perto & $\begin{array}{l}\text { c) Na mesma Região } \\
\text { Administrativa }\end{array}$ & $\begin{array}{l}\text { d) Qualquer Região } \\
\text { Administrativa }\end{array}$ & $\begin{array}{l}\text { e) Outro. Qual? } \\
\text { GOIANIA }\end{array}$ \\
\hline
\end{tabular}

\section{Percepção Do Bairro (para proprietários residentes há mais de 5 anos)}

P.39. Diga três aspectos pelos quais você valoriza a Vila Planalto para morar:

1) AMIZADE ENTRE VIZINHOS

2) TRAQUILIDADE

3) PERTO DE TUDO

P.40. Diga três aspectos que você considera negativos da Vila:

1) USÚARIOS DE DROGAS

2) ÔNIBUS DEMORA

3) RESTAURANTES

P.41. Em relação à Vila Planalto, avalie de 1 a 5 , onde 5 é o mais vantajoso e 1 é o menos vantajoso:

a) Proximidade ao trabalho

b) Escola para as crianças

c) É um bairro seguro

d) Tem bom transporte

e) Boa relação como os vizinhos

f) Tem parques e praças

g) Posto de Saúde

h) Comércio e supermercados

i) Casas-apartamentos baratos

j) Feira de frutas e legumes barata

k) Moram meus familiares, amigos, ou conterrâneos.

\begin{tabular}{|c|c|c|c|c|}
\hline \multirow[t]{2}{*}{1} & 2 & 3 & 4 & 5 \\
\hline & & & & $\mathrm{X}$ \\
\hline \multicolumn{5}{|l|}{$\mathrm{X}$} \\
\hline & & & & $\mathrm{X}$ \\
\hline & & $\mathrm{X}$ & & \\
\hline & & & & $\mathrm{X}$ \\
\hline & & & $\mathrm{X}$ & \\
\hline & & & & $\mathrm{X}$ \\
\hline & & & & X \\
\hline \multicolumn{5}{|l|}{$X$} \\
\hline & & X & & \\
\hline & & & & $\mathrm{X}$ \\
\hline
\end{tabular}

\begin{tabular}{|c|c|c|c|}
\hline \multicolumn{2}{|r|}{ P.42. Que novos serviços têm chegado ao bairro nos últimos 5 anos? } & Sim & Não \\
\hline a) & Clínicas de saúde (medicina, odontologia, etc.) & & $\mathrm{X}$ \\
\hline b) & Academias & $\mathrm{X}$ & \\
\hline c) & Restaurantes & $\mathrm{X}$ & \\
\hline d) & Bares e Lanchonetes & $\mathrm{X}$ & \\
\hline e) & Quiosques de comida & & $\mathrm{X}$ \\
\hline f) & Salões de beleza & $\mathrm{X}$ & \\
\hline g) & Supermercados & & $\mathrm{X}$ \\
\hline h) & Lojas de comércio & $\mathrm{X}$ & \\
\hline i) & Casas de festas & & $\mathrm{X}$ \\
\hline j) & Outro. Qual? & & \\
\hline
\end{tabular}

P.43. Nos últimos cinco anos, que obras foram feitas no bairro?

\begin{tabular}{|c|c|c|c|}
\hline \multicolumn{2}{|c|}{ P.43. Nos últimos cinco anos, que obras foram feitas no bairro? } & Sim & Não \\
\hline a) & Iluminação de ruas e ruelas & $\mathrm{X}$ & \\
\hline b) & Melhoramentos de praças e largos & & $\mathrm{X}$ \\
\hline d) & Sinalizações & & $\mathrm{X}$ \\
\hline e) & Semáforos & $\mathrm{X}$ & \\
\hline
\end{tabular}




\begin{tabular}{|c|c|c|c|}
\hline \multicolumn{2}{|r|}{$\begin{array}{l}\text { P.44. Que impactos tem provocado as transformações dos últimos anos e a construção de } \\
\text { apartamentos e quitinetes? }\end{array}$} & \multirow[t]{2}{*}{ Sim } & \multirow{2}{*}{$\begin{array}{l}\text { Não } \\
\mathrm{X}\end{array}$} \\
\hline a) & Sombra algumas horas & & \\
\hline b) & Interrompe a vista & & $\mathrm{X}$ \\
\hline c) & Melhorou a iluminação do bairro & & $\mathrm{X}$ \\
\hline d) & Melhorou a segurança no bairro & & $\mathrm{X}$ \\
\hline e) & Aumentou o fluxo de veículos & $\mathrm{X}$ & \\
\hline f) & Aumento dos preços no comércio & & $\mathrm{X}$ \\
\hline g) & No percebi nenhum efeito direto & & $\mathrm{X}$ \\
\hline h) & Outro. Qual? VALORIZAÇAO DO PREÇOS DE ALUGUEL & & \\
\hline
\end{tabular}

P.45. Qual qualificação de 1 a 5 você daria para a qualidade de vida no bairro antes da construção de apartamentos/quitinetes?

P.46. Qual qualificação de 1 a 5 você daria para a qualidade de vida no bairro depois da construção de 5 apartamento/quitinetes? MUITA ESPECULAÇAO

P.47. O que você acha que pode acontecer neste bairro em alguns anos se continuar a construção de apartamentos e quitinetes ou de terceiros e quartos pavimentos?

a) Mudariam consideravelmente os moradores e as famílias da Vila

b) Existiram mudanças, mas pouco importantes

c) Continuará como agora

d) Outro. Qual? PRESSAO PARA VENDER E SAIR

\begin{tabular}{|l|l|l}
\hline Informação de contato: (se tiver interesse & Telefone: & Mail:
\end{tabular}

em continuar participando do estudo)

\section{Observações do Entrevistador}

\begin{tabular}{|l|l|l|l|}
\hline P.48. Tipo de moradia: & \multicolumn{1}{|l|}{ X } & b) Apartamento & \\
\hline a) Casa & & d) Quitinete-estúdio & \\
\hline c) Habitação em cômodo-cortiço & & f) Tenda ou barraca & \\
\hline e) Flat & & h) Outro. Qual? & \\
\hline g) Uso misto &
\end{tabular}

\begin{tabular}{|l|l|l|}
\hline P.49. Tipo de via onde se localiza a residência: & Sim & Não \\
\hline a) Rua asfaltada & $X$ & \\
\hline b) Calçada & $X$ & \\
\hline c) Meio-fio & $X$ & \\
\hline d) Iluminação pública & $X$ & \\
\hline
\end{tabular}

\begin{tabular}{|l|l|l|l|l|}
\hline \multicolumn{5}{|l|}{ 50. Aparência exterior do imóvel: } \\
\hline $\begin{array}{l}\text { a) Muito } \\
\text { deteriorado }\end{array}$ & b) Deteriorado X & c) Regular & d) Bem cuidado & $\begin{array}{l}\text { e) Muito bem } \\
\text { cuidado }\end{array}$ \\
\hline
\end{tabular}

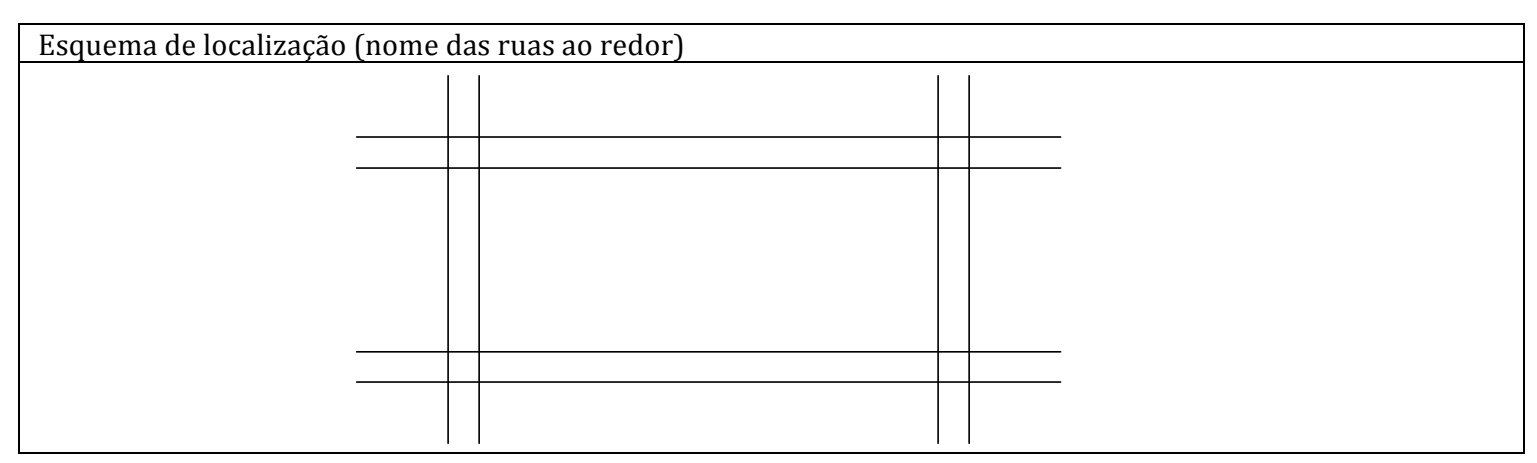




\begin{tabular}{|l|l|l|}
\hline \multicolumn{3}{|c|}{ Levantamento domiciliar para residentes da Vila Planalto 2015} \\
\hline № Folio: 004 & Nome do entrevistador: MATIAS & Data: 23/03/15 \\
\hline \hline Perguntas de filtro: & Condições a cumprir: \\
\hline 1. Mora gente nesta casa? & a) Domicílio particular permanentemente ocupado \\
\hline 2. Está presente o proprietário ou locatário? & b) Pode responder proprietário, locatário, cônjuge ou filho +18. \\
\hline 3. Há quanto tempo mora aqui? & c) Ocupar o domicílio há pelo menos 1 ano. \\
\hline
\end{tabular}

\begin{tabular}{|c|c|c|c|c|c|c|c|}
\hline $\begin{array}{c}\text { Acampamento } \\
\text { /Quarteirão }\end{array}$ & Nome da rua & № Lote & $\begin{array}{c}\text { № Casa- } \\
\text { Apto. }\end{array}$ & $\begin{array}{c}\text { Rua de } \\
\text { referência }\end{array}$ & $\begin{array}{c}\text { Proprie- } \\
\text { tário }\end{array}$ & $\begin{array}{c}\text { Aluguel } \\
\text { casa }\end{array}$ & $\begin{array}{c}\text { Aluguel } \\
\text { apto. }\end{array}$ \\
\hline TAMBORIL / B & RUA 2 & & 13 & & $\mathrm{X}$ & & \\
\hline
\end{tabular}

\section{PARTE I. Características do Domicílio}

\begin{tabular}{|c|c|c|c|c|c|c|c|c|}
\hline $\begin{array}{l}\text { a) Próprio já pago } \\
X\end{array}$ & \multicolumn{2}{|c|}{$\begin{array}{l}\text { b) Próprio ainda } \\
\text { pagando }\end{array}$} & \multicolumn{2}{|c|}{$\begin{array}{l}\text { c) Cedido por } \\
\text { empregador }\end{array}$} & \multicolumn{3}{|c|}{$\begin{array}{l}\text { d) Cedido de outra } \\
\text { condição }\end{array}$} & $\begin{array}{l}\text { e) Outra condição. } \\
\text { Qual? }\end{array}$ \\
\hline \multicolumn{7}{|c|}{ P.2. Em que ano foi construída esta casa ou apartamento aproximadamente? } & \multicolumn{2}{|c|}{ HÁ 10 ANOS } \\
\hline \multicolumn{7}{|c|}{ P.3. Quantos banheiros de uso exclusivo dos moradores este domicílio tem? } & \multicolumn{2}{|l|}{6} \\
\hline \multicolumn{9}{|c|}{ P.4. Quantos veículos existem neste domicílio? (№) } \\
\hline a) Automóvel & b) Utilitário & c) Carga & d) Moto & & & & Carroça & g) Outro. Qual? \\
\hline 1 & & & & & & & & \\
\hline
\end{tabular}

\begin{tabular}{|l|l|l|l|l|}
\hline \multicolumn{5}{|l|}{ P.5. Quantos serviços tem contratado? (№) } \\
\hline a) Internet & b) TV por assinatura & c) Assinatura jornais & d) Assinatura revistas & e) Outros. Qual? \\
\hline $\mathrm{X}$ & $\mathrm{X}$ & CORREIO BRA. & & \\
\hline
\end{tabular}

P.6. Tem algum empregado trabalhando na sua casa?
a) $\mathrm{Sim}$
b) Não X
c) Quantos?

\section{PARTE II. Caraterísticas dos Moradores}

\begin{tabular}{|l|l|}
\hline P.7. Há quantos anos o seu grupo familiar mora neste domicílio? (№) & 44 \\
\hline P.8. Há quantos anos o seu grupo familiar reside na Vila Planalto? (№) & 44 \\
\hline P.9. Há quantos anos reside no Distrito Federal? (№) & 1957 \\
\hline P.10. Em que lugar morou antes de chegar na Vila? (Bairro/Município-RA/Estado) & AC. NACIONAL / RG \\
\hline
\end{tabular}

P.11. Listado de moradores: (incluir pessoa que responde)

\begin{tabular}{|c|c|c|c|c|c|c|c|}
\hline № & a) Nome & b) Sexo & c) Idade & $\begin{array}{l}\text { d) Parentesco } \\
\text { com responsável }\end{array}$ & $\begin{array}{l}\text { e) Lugar trabalho } \\
\text { ou estudo }\end{array}$ & $\begin{array}{l}\text { f) Nível de } \\
\text { escolaridade }\end{array}$ & $\begin{array}{l}\text { g) Situação } \\
\text { laboral atual }\end{array}$ \\
\hline 1 & JOSÉ & M & 75 & 1 & APOSENTADO & 11 & 3 \\
\hline 2 & MARIA & $\mathrm{F}$ & 56 & 2 & EM CASA & 9 & 6 \\
\hline 3 & DALVA & $\mathrm{F}$ & 58 & 11 & TERRACAP & 11 & 2 \\
\hline 4 & & & & & & & \\
\hline 5 & & & & & & & \\
\hline 6 & & & & & & & \\
\hline 7 & & & & & & & \\
\hline 8 & & & & & & & \\
\hline 9 & & & & & & & \\
\hline 10 & & & & & & & \\
\hline
\end{tabular}
b) Sexo ou gênero
M. Masculino
F. Feminino

\begin{tabular}{|l|l|l|}
\hline d) Parentesco com o responsável pelo domicílio \\
\hline Código resposta & Código resposta & Código resposta \\
\hline 1. Pessoa responsável & 2. Cônjuge ou companheira(o) & 3. Filha(o) dos responsáveis \\
\hline 4. Genro ou nora & 5. Pai, mãe, padrasto ou madrasta & 6. Sogra(o) \\
\hline 7. Neta(o) & 8. Bisneta(o) & 9. Irmã ou irmão \\
\hline 10. Avô ou Avó & 11. Outro parente & 12. Agregada(o) \\
\hline
\end{tabular}




\begin{tabular}{|l|l|l|}
\hline f) Nível de escolaridade & 2. Sabe ler e escrever & 3. Alfabetização de adultos \\
\hline 1. Não sabe ler e escrever & 5. Jardim I-II ou Pré-escolar & 6. Fundamental incompleto \\
\hline 4. Maternal e Creche & 8. Médio incompleto & 9. Médio completo \\
\hline 7. Fundamental completo & 11. Superior completo & 12. Especialização \\
\hline 10. Superior incompleto & 14. Doutorado & 15. Não sabe \\
\hline 13. Mestrado &
\end{tabular}

\begin{tabular}{|l|l|}
\hline g) Situação laboral atual $(+10$ anos $)$ \\
\hline 1. Sem atividade & 2. Com trabalho remunerado \\
\hline 3. Aposentado & 4. Aposentado trabalhando \\
\hline 5. Pensionista & 6. Trabalho do lar \\
\hline 7. Desempregado & 8. Estudante \\
\hline 9. Voluntário & 10. Menor de 10 anos \\
\hline
\end{tabular}

P.12. A sua cor ou raça é:
a) Branca $X$
b) Preta
c) Amarela
d) Parda
e) Indígena

\begin{tabular}{|l|l}
\hline P.13. Qual é o tempo total de deslocamento entre seu domicílio e suas atividades cotidianas? & 0 MINUTOS
\end{tabular}

\begin{tabular}{|l|l|l|l|l|l|l|l|}
\hline \multicolumn{2}{|l|}{ P.14. Qual é o modo de deslocamento entre seu domicílio e suas atividades cotidianas? } \\
\hline a) A pé & b) Bicicleta & c) Moto & d) Carro & e) Carona & f) Ônibus & g) Taxi & h) Outros. Qual? \\
\hline & & & X & & X & & \\
\hline
\end{tabular}

P.15. Que lugar é o mais utilizado para o lazer?

\begin{tabular}{|l|l|}
\hline a) A própria residência X & b) Espaços comuns (condomínios) \\
\hline c) Outras residências do bairro & d) Outras residências fora do bairro \\
\hline $\begin{array}{l}\text { e) Espaços públicos abertos no bairro (praças, } \\
\text { parques, bares de calçada) }\end{array}$ & f) Espaços públicos fora do bairro \\
\hline $\begin{array}{l}\text { g) Locais irrestritos fechados (restaurantes, cinemas, } \\
\text { teatro, shopping) }\end{array}$ & h) Locais de acesso restritos (clubes, associações) \\
\hline i) Outro. Qual? BRASíLIA MOTO NAUTICA & \\
\hline
\end{tabular}

P.16. Suas compras costumam ser realizadas dentro do bairro? Em alguma loja em particular?
a) $\operatorname{Sim} X$
b) Não
c) Qual? ARMAZEM DE GERALDO

\section{PARTE III. Grau de Instrução, Trabalho e Renda}

\begin{tabular}{|l|l|l|l|l|l|}
\hline P.17 Qual é sua ocupação atual? & X & b) Empregado com CT & c) Empregado sem CT & \\
\hline a) Não trabalha & & e) Serviço público-militar & & f) Autônomo & \\
\hline d) Temporário & & h) Estagiário & & i) Cargo comissionado & \\
\hline g) Empregador & & k) Outro. Qual? & \multicolumn{2}{l|}{} \\
\hline j) Trabalho no remunerado
\end{tabular}

\begin{tabular}{|l|l|l|}
\hline \multicolumn{3}{|l|}{ P.18. Algum integrante do domicílio recebe alguma ajuda ou bolsa (subsídio) por parte do Estado? } \\
\hline a) Sim & b) Não X & c) Qual? \\
\hline
\end{tabular}

\begin{tabular}{|l|l}
\hline P.20. Qual foi seu rendimento total do mês passado, incluindo salário e outras fontes de renda? (R\$) & $6.000,00$
\end{tabular}

\begin{tabular}{|l|l} 
P.21. Considerando todos os ingressos do lar (incluindo salários, bolsas, aposentadorias, alugueis e & $10.000,00$
\end{tabular} outras rendas), qual foi o valor aproximado da renda familiar mensal no último mês? (R\$) 


\section{Situação Fundiária Atual}

\begin{tabular}{|l|l|l|l|l|}
\hline P.22. Que tipo documento de posse do imóvel possui? & e) Outro. Qual? \\
\hline $\begin{array}{l}\text { a) Não é } \\
\text { proprietário }\end{array}$ & b) Concessão de uso & $\begin{array}{l}\text { c) Contrato de } \\
\text { compra-venda }\end{array}$ & $\begin{array}{l}\text { d) Título de } \\
\text { domínio X }\end{array}$ \\
\begin{tabular}{|l|l|l|l|}
\hline P.23. Como adquiriu o imóvel? & b) Recebeu do \\
a) Não é \\
proprietário
\end{tabular} & $\begin{array}{l}\text { c) Recebeu de } \\
\text { herança }\end{array}$ & $\begin{array}{l}\text { d) Comprou de } \\
\text { terceiros }\end{array}$ & e) Outro. Qual? \\
\hline
\end{tabular}

\begin{tabular}{|l|c|}
\hline P.24. Qual foi o preço aproximado que pagou por este imóvel? (R\$) & $196.000,00$ \\
\hline P.25. Se aluga. Qual é o valor aproximado do aluguel por este imóvel? (R\$) & \\
\hline
\end{tabular}

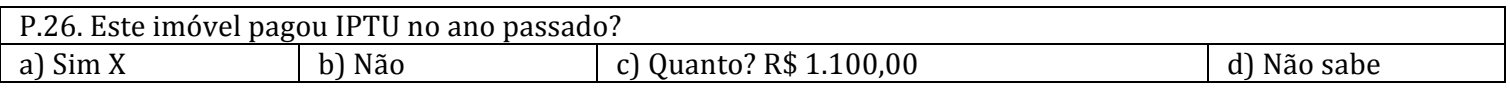

\section{Situação Imobiliária Atual (para proprietários residentes há mais de 5 anos)}

P.27. Nos últimos 12 meses têm sido publicados avisos ou cartazes para vender ou alugar esta propriedade?

\begin{tabular}{|c|c|c|}
\hline a) $\operatorname{Sim}$ & b) Não X & c) Que tipo? (casa, apartamento, quitinete, cômodo, loja) \\
\hline \multicolumn{3}{|c|}{$\begin{array}{l}\text { P.28. Nos últimos } 12 \text { meses tem recebido visitas de pessoas ou corretores de imóveis interessados em comprar } \\
\text { ou alugar esta propriedade? }\end{array}$} \\
\hline a) $\operatorname{Sim} X$ & b) Não & c) Quantos? \\
\hline \multicolumn{3}{|c|}{ P.29. Nos últimos 12 meses tem recebido alguma oferta concreta para comprar ou alugar esta propriedade? } \\
\hline a) $\mathrm{Sim}$ & b) Não X & c) Que valor? \\
\hline \multicolumn{3}{|c|}{ P.30. De alguma empresa ou pessoa particular? } \\
\hline a) Empresa & b) Particular & c) Outro. Qual? \\
\hline
\end{tabular}

P.31. Sabe de algum vizinho deste quarteirão que tenha vendido ou mantenha conversações para vender sua propriedade?
a) $\mathrm{Sim}$
b) Não X

P.32. 0 preço desta propriedade, hoje comparado há 5 anos, você acredita que:
a) aumentou muito
b) aumentou algo $\mathrm{X}$
c) está igual
d) diminuiu algo
e) diminui muito

\begin{tabular}{|c|c|c|c|c|c|}
\hline \multicolumn{6}{|l|}{ P.33. Por que você pensa que isto acontece? } \\
\hline $\begin{array}{l}\text { a) Infraestrutura pública (pavimentação } \\
\text { de vias, pontos de ônibus, esgoto, etc.) }\end{array}$ & $\operatorname{Sim} X$ & Não & b) Comércio, restaurantes e serviços & $\begin{array}{l}\text { Sim } \\
\mathrm{X}\end{array}$ & Não \\
\hline c) Edifícios de apartamentos-quitinetes & $\operatorname{Sim} X$ & Não & d) Outro. Qual? ENTREGA DE ESCRIT & AS & \\
\hline
\end{tabular}

\section{Preferências Habitacionais Futuras (para proprietários residentes há mais de 5 anos)}

P.34. Pensando em seus planos de vida nos próximos cinco anos, com que frase se identifica mais?

\begin{tabular}{|l|l|}
\hline a) Não me interessa nada mudar de casa nem de bairro & $\mathrm{X}$ \\
\hline b) Me interessaria muito mudar de casa ou de bairro & \\
\hline c) Me interessa mas não tenho o dinheiro & \\
\hline d) Só me interessaria caso me ofereçam um bom preço por minha propriedade & \\
\hline e) Outro. Qual? & \\
\hline
\end{tabular}

\begin{tabular}{|l|l|}
\hline P.35. Se hoje você vendesse sua propriedade, por que valor acredita que seria? & $3.200 .000,00$ \\
(R\$)
\end{tabular}

P.36. Qual seria o valor máximo que gastaria em comprar ou alugar outra propriedade?
a) Comprar
b) Alugar
c) Valor(R $\$$ ) 0 


\begin{tabular}{|l|l|l|l|l|}
\hline \multicolumn{2}{|l}{ P.37. Em caso de comprar ou alugar, você preferiria? } \\
\hline a) & Casa & v/s & b) X & Apartamento \\
\hline a) X & Nova(o) & v/s & b) & Usada(o) \\
\hline a) & Isolada em lote & v/s & b) & Condomínio \\
\hline a) & Casa grande com quintal pequeno & v/s & b) & Casa pequena com quintal grande \\
\hline a) X & Apto. pequeno bem localizado & v/s & b) & Apto. grande em qualquer setor \\
\hline
\end{tabular}

P.38. Em caso de comprar ou alugar, que lugar preferiria para viver?

\begin{tabular}{|l|l|l|l|l|}
\hline $\begin{array}{l}\text { a) Na mesma Vila } \\
\text { Planalto X }\end{array}$ & b) Num setor perto & $\begin{array}{l}\text { c) Na mesma Região } \\
\text { Administrativa }\end{array}$ & $\begin{array}{l}\text { d) Qualquer Região } \\
\text { Administrativa }\end{array}$ & $\begin{array}{l}\text { e) Outro. Qual? } \\
\text { GOIANIA }\end{array}$ \\
\hline
\end{tabular}

\section{Percepção Do Bairro (para proprietários residentes há mais de 5 anos)}

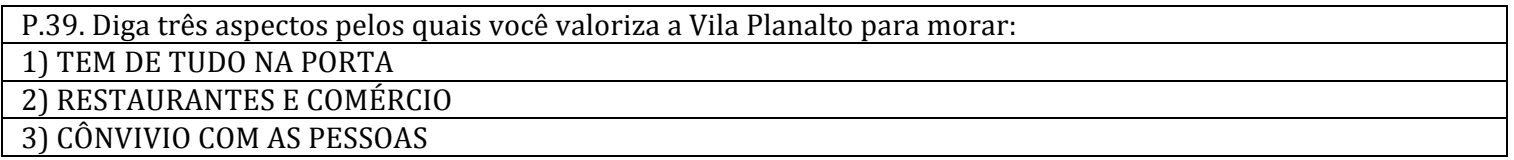

\begin{tabular}{|l|}
\hline P.40. Diga três aspectos que você considera negativos da Vila: \\
\hline 1) ADMINISTRADORES VAGABUNDO NAO OLHAM PARA A COMUNIDADE \\
\hline 2) SÓ VEM PARA BATER A PORTA EM ÉPOCA DE ELEIÇAO \\
\hline 3) NAO FAZEM NADA PELA VILA \\
\hline
\end{tabular}

\begin{tabular}{|c|c|c|c|c|c|c|}
\hline \multicolumn{2}{|r|}{$\begin{array}{l}\text { P.41. Em relação à Vila Planalto, avalie de } 1 \text { a } 5 \text {, onde } 5 \text { é o mais vantajoso e } 1 \text { é o } \\
\text { menos vantajoso: }\end{array}$} & \multirow[t]{2}{*}{1} & \multirow[t]{2}{*}{2} & \multirow[t]{2}{*}{3} & \multirow{2}{*}{\begin{tabular}{|l|}
4 \\
$X$ \\
\end{tabular}} & \multirow[t]{2}{*}{5} \\
\hline a) & Proximidade ao trabalho & & & & & \\
\hline b) & Escola para as crianças & $\mathrm{X}$ & & & & \\
\hline c) & É um bairro seguro & & & & & $\mathrm{X}$ \\
\hline d) & Tem bom transporte & & & & $\mathrm{X}$ & \\
\hline e) & Boa relação como os vizinhos & & & & & $\mathrm{X}$ \\
\hline f) & Tem parques e praças & & & & $\mathrm{X}$ & \\
\hline g) & Posto de Saúde & & & & & $\mathrm{X}$ \\
\hline h) & Comércio e supermercados & & & $\mathrm{X}$ & & \\
\hline i) & Casas-apartamentos baratos & & $\mathrm{X}$ & & & \\
\hline j) & Feira de frutas e legumes barata & $\mathrm{X}$ & & & & \\
\hline k) & Moram meus familiares, amigos, ou conterrâneos. & & & $\mathrm{X}$ & & \\
\hline
\end{tabular}

\begin{tabular}{|l|l|l|l|}
\hline P.42. Que novos serviços têm chegado ao bairro nos últimos 5 anos? & Sim & Não \\
\hline a) & Clínicas de saúde (medicina, odontologia, etc.) & & X \\
\hline b) & Academias & $\mathrm{X}$ & \\
\hline c) & Restaurantes & $\mathrm{X}$ & \\
\hline d) & Bares e Lanchonetes & $\mathrm{X}$ & \\
\hline e) & Quiosques de comida & & $\mathrm{X}$ \\
\hline f) & Salões de beleza & $\mathrm{X}$ & \\
\hline g) & Supermercados & $\mathrm{X}$ & \\
\hline h) & Lojas de comércio & & $\mathrm{X}$ \\
\hline i) & Casas de festas & & \\
\hline j) & Outro. Qual? & & \\
\hline
\end{tabular}

\begin{tabular}{|l|l|l|l|}
\hline P.43. Nos últimos cinco anos, que obras foram feitas no bairro? & Sim & Não \\
\hline a) & Iluminação de ruas e ruelas & & X \\
\hline b) & Melhoramentos de praças e largos & $\mathrm{X}$ & \\
\hline c) & Pavimentação de ruas e calçadas & $\mathrm{X}$ & \\
\hline d) & Sinalizações & & $\mathrm{X}$ \\
\hline e) & Semáforos & & $\mathrm{X}$ \\
\hline f) & Quebra molas & $\mathrm{X}$ & \\
\hline g) & Outra. Qual? & \\
\hline
\end{tabular}




\begin{tabular}{|l|l|l|l|}
\hline $\begin{array}{l}\text { P.44. Que impactos tem provocado as transformações dos últimos anos e a construção de } \\
\text { apartamentos e quitinetes? }\end{array}$ & Sim & Não \\
\hline a) & Sombra algumas horas & $\mathrm{X}$ & \\
\hline b) & Interrompe a vista & $\mathrm{X}$ & \\
\hline c) & Melhorou a iluminação do bairro & & $\mathrm{X}$ \\
\hline d) & Melhorou a segurança no bairro & & $\mathrm{X}$ \\
\hline e) & Aumentou o fluxo de veículos & $\mathrm{X}$ & \\
\hline f) & Aumento dos preços no comércio & $\mathrm{X}$ & \\
\hline g) & No percebi nenhum efeito direto & & $\mathrm{X}$ \\
\hline h) & Outro. Qual? AUMENTOU A VIZINHANÇA & \\
\hline
\end{tabular}

P.45. Qual qualificação de 1 a 5 você daria para a qualidade de vida no bairro antes da construção de 5 apartamentos/quitinetes?

P.46. Qual qualificação de 1 a 5 você daria para a qualidade de vida no bairro depois da construção de 2 apartamento/quitinetes? MUITA ESPECULAÇAO

P.47. O que você acha que pode acontecer neste bairro em alguns anos se continuar a construção de apartamentos e quitinetes ou de terceiros e quartos pavimentos?

a) Mudariam consideravelmente os moradores e as famílias da Vila

b) Existiram mudanças, mas pouco importantes

c) Continuará como agora

d) Outro. Qual? O PIONEIRO VAI VENDER

\begin{tabular}{|l|l|l|}
\hline Informação de contato: (se tiver interesse & Telefone: & Mail:
\end{tabular}

em continuar participando do estudo)

\section{Observações do Entrevistador}

P.48. Tipo de moradia:

\begin{tabular}{|l|l|l|l|}
\hline a) Casa & \multicolumn{1}{|c|}{ X } & b) Apartamento & \\
\hline c) Habitação em cômodo-cortiço & & d) Quitinete-estúdio & \\
\hline e) Flat & & f) Tenda ou barraca & \\
\hline g) Uso misto & & h) Outro. Qual? & \\
\hline
\end{tabular}

P.49. Tipo de via onde se localiza a residência:

a) Rua asfaltada

b) Calçada

c) Meio-fio

d) Iluminação pública

\begin{tabular}{|l|l|}
\hline Sim & Não \\
\hline$X$ & \\
\hline$X$ & \\
\hline$X$ & \\
\hline$X$ & \\
\hline
\end{tabular}

\begin{tabular}{|c|c|c|c|c|}
\hline \multicolumn{5}{|c|}{ 50. Aparência exterior do imóvel: } \\
\hline $\begin{array}{l}\text { a) Muito } \\
\text { deteriorado }\end{array}$ & b) Deteriorado & c) Regular & d) Bem cuidado & $\begin{array}{l}\text { e) Muito bem } \\
\text { cuidado X }\end{array}$ \\
\hline
\end{tabular}

\begin{tabular}{|l|l|l|l|l|}
\hline Esquema de localização (nome das ruas ao redor) \\
\hline & & & & \\
\hline & & & & \\
\hline & & & & \\
\hline & & & & \\
\hline & & & & \\
\hline
\end{tabular}




\begin{tabular}{|l|l|l|}
\hline \multicolumn{3}{|c|}{ Levantamento domiciliar para residentes da Vila Planalto 2015} \\
\hline № Folio: 005 & Nome do entrevistador: MATIAS & Data: 23/03/15 \\
\hline \hline Perguntas de filtro: & Condições a cumprir: \\
\hline 1. Mora gente nesta casa? & a) Domicílio particular permanentemente ocupado \\
\hline 2. Está presente o proprietário ou locatário? & b) Pode responder proprietário, locatário, cônjuge ou filho +18. \\
\hline 3. Há quanto tempo mora aqui? & c) Ocupar o domicílio há pelo menos 1 ano. \\
\hline
\end{tabular}

\begin{tabular}{|c|c|c|c|c|c|c|c|}
\hline $\begin{array}{c}\text { Acampamento } \\
\text { /Quarteirão }\end{array}$ & Nome da rua & № Lote & $\begin{array}{c}\text { № Casa- } \\
\text { Apto. }\end{array}$ & $\begin{array}{c}\text { Rua de } \\
\text { referência }\end{array}$ & $\begin{array}{c}\text { Proprie- } \\
\text { tário }\end{array}$ & $\begin{array}{c}\text { Aluguel } \\
\text { casa }\end{array}$ & $\begin{array}{c}\text { Aluguel } \\
\text { apto. }\end{array}$ \\
\hline TAMBORIL / B & RUA 1 & & 18 & & $\mathrm{X}$ & & \\
\hline
\end{tabular}

\section{PARTE I. Características do Domicílio}

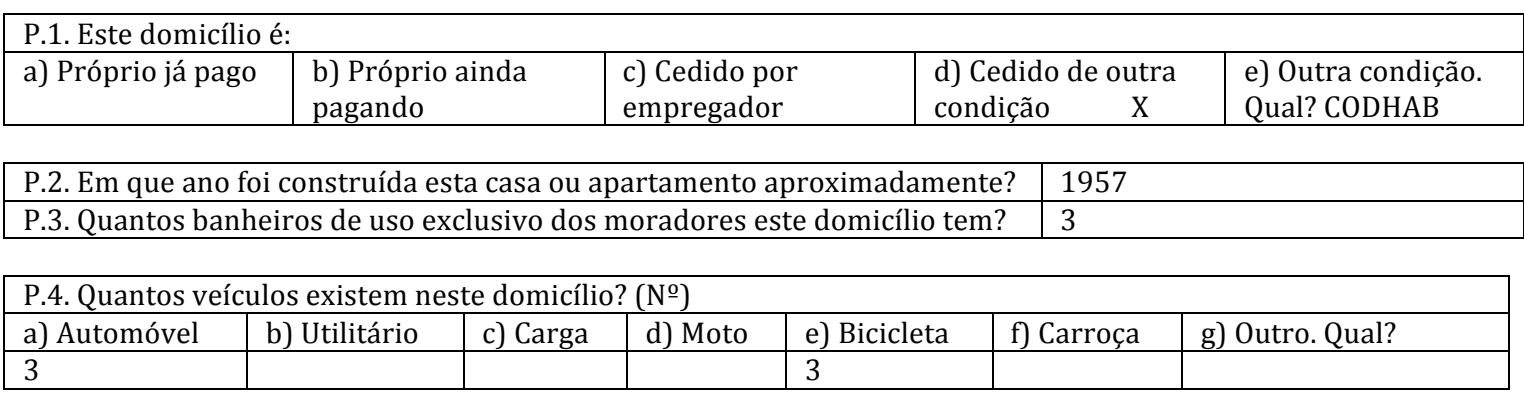

\begin{tabular}{|l|l|l|l|l|}
\hline \multicolumn{2}{|l|}{ P.5. Quantos serviços tem contratado? (№) } \\
\hline a) Internet & b) TV por assinatura & c) Assinatura jornais & d) Assinatura revistas & e) Outros. Qual? \\
\hline $\mathrm{X}$ & $\mathrm{X}$ & CORREIO BRA. & & \\
\hline
\end{tabular}

P.6. Tem algum empregado trabalhando na sua casa?
a) $\operatorname{Sim} X$
b) Não
c) Quantos? 1

\section{PARTE II. Caraterísticas dos Moradores}

\begin{tabular}{|l|l|}
\hline P.7. Há quantos anos o seu grupo familiar mora neste domicílio? (№) & 50 \\
\hline P.8. Há quantos anos o seu grupo familiar reside na Vila Planalto? (№) & 50 \\
\hline P.9. Há quantos anos reside no Distrito Federal? (№) & 50 \\
\hline P.10. Em que lugar morou antes de chegar na Vila? (Bairro/Município-RA/Estado) & GOIANIA \\
\hline
\end{tabular}

P.11. Listado de moradores: (incluir pessoa que responde)

\begin{tabular}{|c|c|c|c|c|c|c|c|}
\hline № & a) Nome & b) Sexo & c) Idade & $\begin{array}{l}\text { d) Parentesco } \\
\text { com responsável }\end{array}$ & $\begin{array}{l}\text { e) Lugar trabalho } \\
\text { ou estudo }\end{array}$ & $\begin{array}{l}\text { f) Nível de } \\
\text { escolaridade }\end{array}$ & $\begin{array}{l}\text { g) Situação } \\
\text { laboral atual }\end{array}$ \\
\hline 1 & RODOLFO & M & 78 & 1 & ADM.EMPRESA & 9 & 4 \\
\hline 2 & ISABEL & $\mathrm{F}$ & 75 & 2 & EM CASA & 7 & 6 \\
\hline 3 & VALERIA & $\mathrm{F}$ & 51 & 3 & PLANO PILOTO & 11 & 2 \\
\hline 4 & & & & & & & \\
\hline 5 & & & & & & & \\
\hline 6 & & & & & & & \\
\hline 7 & & & & & & & \\
\hline 8 & & & & & & & \\
\hline 9 & & & & & & & \\
\hline 10 & & & & & & & \\
\hline
\end{tabular}
b) Sexo ou gênero
M. Masculino
F. Feminino

\begin{tabular}{|l|l|l|}
\hline d) Parentesco com o responsável pelo domicílio \\
\hline Código resposta & Código resposta & Código resposta \\
\hline 1. Pessoa responsável & 2. Cônjuge ou companheira(o) & 3. Filha(o) dos responsáveis \\
\hline 4. Genro ou nora & 5. Pai, mãe, padrasto ou madrasta & 6. Sogra(o) \\
\hline 7. Neta(o) & 8. Bisneta(o) & 9. Irmã ou irmão \\
\hline 10. Avô ou Avó & 11. Outro parente & 12. Agregada(o) \\
\hline
\end{tabular}




\begin{tabular}{|l|l|l|}
\hline f) Nível de escolaridade & 2. Sabe ler e escrever & 3. Alfabetização de adultos \\
\hline 1. Não sabe ler e escrever & 5. Jardim I-II ou Pré-escolar & 6. Fundamental incompleto \\
\hline 4. Maternal e Creche & 8. Médio incompleto & 9. Médio completo \\
\hline 7. Fundamental completo & 11. Superior completo & 12. Especialização \\
\hline 10. Superior incompleto & 14. Doutorado & 15. Não sabe \\
\hline 13. Mestrado &
\end{tabular}

\begin{tabular}{|l|l|}
\hline g) Situação laboral atual $(+10$ anos $)$ \\
\hline 1. Sem atividade & 2. Com trabalho remunerado \\
\hline 3. Aposentado & 4. Aposentado trabalhando \\
\hline 5. Pensionista & 6. Trabalho do lar \\
\hline 7. Desempregado & 8. Estudante \\
\hline 9. Voluntário & 10. Menor de 10 anos \\
\hline
\end{tabular}

P.12. A sua cor ou raça é:
a) Branca $X$
b) Preta
c) Amarela
d) Parda
e) Indígena

\begin{tabular}{|l|l|l|l}
\hline P.13. Qual é o tempo total de deslocamento entre seu domicílio e suas atividades cotidianas? & 30 MINUTOS \\
\hline
\end{tabular}

\begin{tabular}{|l|l|l|l|l|l|l|l|}
\hline \multicolumn{2}{|l|}{ P.14. Qual é o modo de deslocamento entre seu domicílio e suas atividades cotidianas? } \\
\hline a) A pé & b) Bicicleta & c) Moto & d) Carro & e) Carona & f) Ônibus & g) Taxi & h) Outros. Qual? \\
\hline & & & X & & & & \\
\hline
\end{tabular}

P.15. Que lugar é o mais utilizado para o lazer?

\begin{tabular}{|l|l|}
\hline a) A própria residência & b) Espaços comuns (condomínios) \\
\hline c) Outras residências do bairro & d) Outras residências fora do bairro \\
\hline $\begin{array}{l}\text { e) Espaços públicos abertos no bairro (praças, } \\
\text { parques, bares de calçada) }\end{array}$ & f) Espaços públicos fora do bairro \\
\hline $\begin{array}{l}\text { g) Locais irrestritos fechados (restaurantes, cinemas, } \\
\text { teatro, shopping) }\end{array}$ & h) Locais de acesso restritos (clubes, associações) X \\
\hline i) Outro. Qual? BRASÍLIA MOTO NAUTICA & \\
\hline
\end{tabular}

P.16. Suas compras costumam ser realizadas dentro do bairro? Em alguma loja em particular?
a) $\operatorname{Sim}$
b) Não X
c) Qual? ATACADAO

\section{PARTE III. Grau de Instrução, Trabalho e Renda}

\begin{tabular}{|l|l|l|l|l|l|}
\hline P.17 Qual é sua ocupação atual? & b) Empregado com CT & & c) Empregado sem CT & \\
\hline a) Não trabalha & & e) Serviço público-militar & X & f) Autônomo & \\
\hline d) Temporário & & h) Estagiário & & i) Cargo comissionado & \\
\hline g) Empregador & k) Outro. Qual? \\
\hline j) Trabalho no remunerado & & \multicolumn{3}{l|}{} \\
\hline
\end{tabular}

\begin{tabular}{|l|l|l|}
\hline \multicolumn{3}{|l|}{ P.18. Algum integrante do domicílio recebe alguma ajuda ou bolsa (subsídio) por parte do Estado? } \\
\hline a) Sim & b) Não X & c) Qual? \\
\hline
\end{tabular}

\begin{tabular}{|l|l}
\hline P.20. Qual foi seu rendimento total do mês passado, incluindo salário e outras fontes de renda? (R\$) & $6.000,00$
\end{tabular}

$\begin{array}{ll}\text { P.21. Considerando todos os ingressos do lar (incluindo salários, bolsas, aposentadorias, alugueis e } & 6.000,00\end{array}$ outras rendas), qual foi o valor aproximado da renda familiar mensal no último mês? (R\$) 


\section{Situação Fundiária Atual}

\begin{tabular}{|l|l|l|l|l|}
\hline P.22. Que tipo documento de posse do imóvel possui? & e) Outro. Qual? \\
\hline $\begin{array}{l}\text { a) Não é } \\
\text { proprietário }\end{array}$ & $\begin{array}{l}\text { b) Concessão de uso } \\
\mathrm{X}\end{array}$ & $\begin{array}{l}\text { c) Contrato de } \\
\text { compra-venda }\end{array}$ & $\begin{array}{l}\text { d) Título de } \\
\text { domínio }\end{array}$ \\
\begin{tabular}{|l|l|l|l|}
\hline P.23. Como adquiriu o imóvel? & b) Recebeu do \\
a) Não é \\
proprietário
\end{tabular} & $\begin{array}{l}\text { c) Recebeu de } \\
\text { herança }\end{array}$ & $\begin{array}{l}\text { d) Comprou de } \\
\text { terceiros }\end{array}$ & e) Outro. Qual? \\
\hline
\end{tabular}

\begin{tabular}{|l|l|}
\hline P.24. Qual foi o preço aproximado que pagou por este imóvel? (R\$) & \\
\hline P.25. Se aluga. Qual é o valor aproximado do aluguel por este imóvel? (R\$) & \\
\hline
\end{tabular}

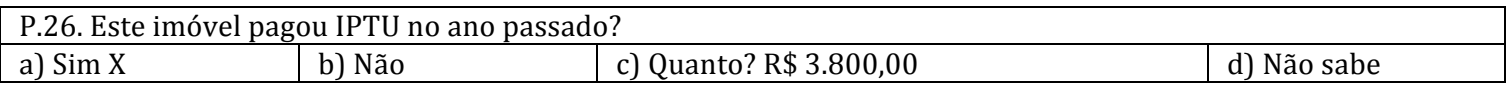

\section{Situação Imobiliária Atual (para proprietários residentes há mais de 5 anos)}

P.27. Nos últimos 12 meses têm sido publicados avisos ou cartazes para vender ou alugar esta propriedade?

\begin{tabular}{|c|c|c|}
\hline a) $\operatorname{Sim}$ & b) Não X & c) Que tipo? (casa, apartamento, quitinete, cômodo, loja) \\
\hline \multicolumn{3}{|c|}{$\begin{array}{l}\text { P.28. Nos últimos } 12 \text { meses tem recebido visitas de pessoas ou corretores de imóveis interessados em comprar } \\
\text { ou alugar esta propriedade? }\end{array}$} \\
\hline a) $\mathrm{Sim}$ & b) Não X & c) Quantos? \\
\hline \multicolumn{3}{|c|}{ P.29. Nos últimos 12 meses tem recebido alguma oferta concreta para comprar ou alugar esta propriedade? } \\
\hline a) $\mathrm{Sim}$ & b) Não & c) Que valor? \\
\hline \multicolumn{3}{|c|}{ P.30. De alguma empresa ou pessoa particular? } \\
\hline a) Empresa & b) Particular & c) Outro. Qual? \\
\hline
\end{tabular}

P.31. Sabe de algum vizinho deste quarteirão que tenha vendido ou mantenha conversações para vender sua propriedade?
a) Sim
$\mathrm{X}$
b) Não

P.32. 0 preço desta propriedade, hoje comparado há 5 anos, você acredita que:

\begin{tabular}{|l|l|l|l|l|}
\hline P.32. O preço desta propriedade, hoje comparado há 5 anos, você acredita que: \\
\hline $\begin{array}{l}\text { a) aumentou muito } \\
\text { X }\end{array}$ & b) aumentou algo & c) está igual & d) diminuiu algo & e) diminui muito \\
\hline
\end{tabular}

P.33. Por que você pensa que isto acontece?

\begin{tabular}{|l|l|l|l|l|}
\hline P.33. Por que você pensa que isto acontece? \\
\hline $\begin{array}{l}\text { a) Infraestrutura pública (pavimentação } \\
\text { de vias, pontos de ônibus, esgoto, etc.) }\end{array}$ & Sim & Não & b) Comércio, restaurantes e serviços & Sim \\
\hline c) Edifícios de apartamentos-quitinetes & Sim & Não & d) Outro. Qual? LOCALIZAÇAO ESTRATÉGICA \\
\hline
\end{tabular}

\section{Preferências Habitacionais Futuras (para proprietários residentes há mais de 5 anos)}

P.34. Pensando em seus planos de vida nos próximos cinco anos, com que frase se identifica mais?

\begin{tabular}{|c|c|}
\hline a) Não me interessa nada mudar de casa nem de bairro & $\mathrm{X}$ \\
\hline b) Me interessaria muito mudar de casa ou de bairro & \\
\hline c) Me interessa mas não tenho o dinheiro & \\
\hline d) Só me interessaria caso me ofereçam um bom preço por minha propriedade & \\
\hline e) Outro. Qual? & \\
\hline $\begin{array}{l}\text { P.35. Se hoje você vendesse sua propriedade, por que valor acredita que seria? } \\
(\mathrm{R} \$)\end{array}$ & $3.000 .000,00$ \\
\hline
\end{tabular}

P.36. Qual seria o valor máximo que gastaria em comprar ou alugar outra propriedade?

\begin{tabular}{|l|l|l|}
\hline a) Comprar & b) Alugar & c) Valor(R $\$$ ) 0 \\
\hline
\end{tabular}




\begin{tabular}{|l|l|l|l|l|}
\hline \multicolumn{5}{|l}{ P.37. Em caso de comprar ou alugar, você preferiria? } \\
\hline a) & Casa & v/s & b) & Apartamento \\
\hline a) & Nova(o) & v/s & b) & Usada(o) \\
\hline a) & Isolada em lote & v/s & b) & Condomínio \\
\hline a) & Casa grande com quintal pequeno & v/s & b) & Casa pequena com quintal grande \\
\hline a) & Apto. pequeno bem localizado & v/s & b) & Apto. grande em qualquer setor \\
\hline
\end{tabular}

P.38. Em caso de comprar ou alugar, que lugar preferiria para viver?

\begin{tabular}{|l|l|l|l|l|}
\hline $\begin{array}{l}\text { a) Na mesma Vila } \\
\text { Planalto }\end{array}$ & b) Num setor perto & $\begin{array}{l}\text { c) Na mesma Região } \\
\text { Administrativa }\end{array}$ & $\begin{array}{l}\text { d) Qualquer Região } \\
\text { Administrativa }\end{array}$ & $\begin{array}{l}\text { e) Outro. Qual? } \\
\text { GOIANIA }\end{array}$ \\
\hline
\end{tabular}

\section{Percepção Do Bairro (para proprietários residentes há mais de 5 anos)}
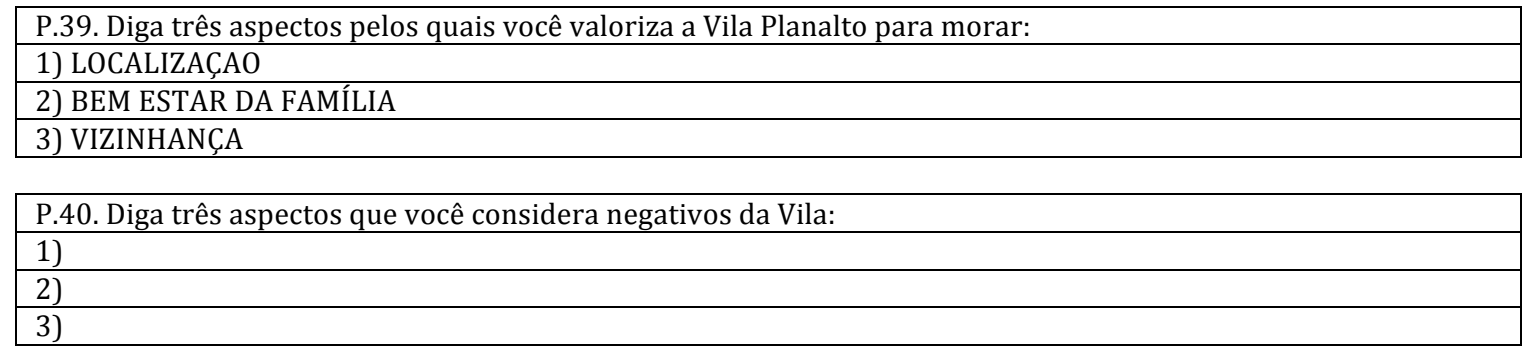

\begin{tabular}{|c|c|c|c|c|c|c|}
\hline \multicolumn{2}{|r|}{$\begin{array}{l}\text { P.41. Em relação à Vila Planalto, avalie de } 1 \text { a } 5 \text {, onde } 5 \text { é o mais vantajoso e } 1 \text { é o } \\
\text { menos vantajoso: }\end{array}$} & 1 & 2 & 3 & 4 & 5 \\
\hline a) & Proximidade ao trabalho & & & & & $\mathrm{X}$ \\
\hline b) & Escola para as crianças & & & & & $\mathrm{X}$ \\
\hline c) & É um bairro seguro & & & & & $\mathrm{X}$ \\
\hline d) & Tem bom transporte & & & & & $\mathrm{X}$ \\
\hline e) & Boa relação como os vizinhos & & & & & $\mathrm{X}$ \\
\hline f) & Tem parques e praças & & & & & $\mathrm{X}$ \\
\hline g) & Posto de Saúde & & & & & $\mathrm{X}$ \\
\hline h) & Comércio e supermercados & & & & & $\mathrm{X}$ \\
\hline i) & Casas-apartamentos baratos & & & & $\mathrm{X}$ & \\
\hline j) & Feira de frutas e legumes barata & & & & & $\mathrm{X}$ \\
\hline $\mathrm{k})$ & Moram meus familiares, amigos, ou conterrâneos. & & & & & $\mathrm{X}$ \\
\hline
\end{tabular}

\begin{tabular}{|l|l|l|l|}
\hline \multicolumn{2}{|l|}{ P.42. Que novos serviços têm chegado ao bairro nos últimos 5 anos? } & Sim & Não \\
\hline a) & Clínicas de saúde (medicina, odontologia, etc.) & $\mathrm{X}$ & \\
\hline b) & Academias & $\mathrm{X}$ & \\
\hline c) & Restaurantes & $\mathrm{X}$ & \\
\hline d) & Bares e Lanchonetes & $\mathrm{X}$ & \\
\hline e) & Quiosques de comida & $\mathrm{X}$ & \\
\hline f) & Salões de beleza & $\mathrm{X}$ & \\
\hline g) & Supermercados & $\mathrm{X}$ & \\
\hline h) & Lojas de comércio & $\mathrm{X}$ & \\
\hline i) & Casas de festas & & \\
\hline j) & Outro. Qual? CLUBE DE VIZINHANÇA DA VILA PLANALTO & & \\
\hline
\end{tabular}

\begin{tabular}{|l|l|l|l|}
\hline \multicolumn{2}{|l|}{ P.43. Nos últimos cinco anos, que obras foram feitas no bairro? } & Sim & Não \\
\hline a) & Iluminação de ruas e ruelas & & X \\
\hline b) & Melhoramentos de praças e largos & $\mathrm{X}$ & \\
\hline c) & Pavimentação de ruas e calçadas & $\mathrm{X}$ & \\
\hline d) & Sinalizações & $\mathrm{X}$ & \\
\hline e) & Semáforos & $\mathrm{X}$ & \\
\hline f) & Quebra molas & $\mathrm{X}$ & \\
\hline g) & Outra. Qual? & & \\
\hline
\end{tabular}




\begin{tabular}{|l|l|l|l|}
\hline $\begin{array}{l}\text { P.44. Que impactos tem provocado as transformações dos últimos anos e a construção de } \\
\text { apartamentos e quitinetes? }\end{array}$ & Sim & Não \\
\hline a) & Sombra algumas horas & $\mathrm{X}$ & \\
\hline b) & Interrompe a vista & $\mathrm{X}$ & \\
\hline c) & Melhorou a iluminação do bairro & $\mathrm{X}$ & \\
\hline d) & Melhorou a segurança no bairro & $\mathrm{X}$ & \\
\hline e) & Aumentou o fluxo de veículos & $\mathrm{X}$ & \\
\hline f) & Aumento dos preços no comércio & $\mathrm{X}$ & \\
\hline g) & No percebi nenhum efeito direto & & $\mathrm{X}$ \\
\hline h) & Outro. Qual? AUMENTOU A VIZINHANÇA & & \\
\hline
\end{tabular}

P.45. Qual qualificação de 1 a 5 você daria para a qualidade de vida no bairro antes da construção de apartamentos/quitinetes?

P.46. Qual qualificação de 1 a 5 você daria para a qualidade de vida no bairro depois da construção de 2 apartamento/quitinetes? MUITA ESPECULAÇAO

P.47. O que você acha que pode acontecer neste bairro em alguns anos se continuar a construção de apartamentos e quitinetes ou de terceiros e quartos pavimentos?

a) Mudariam consideravelmente os moradores e as famílias da Vila

b) Existiram mudanças, mas pouco importantes

c) Continuará como agora

d) Outro. Qual? O PIONEIRO VAI VENDER

\begin{tabular}{|l|l|l}
\hline Informação de contato: (se tiver interesse & Telefone: & Mail:
\end{tabular}

em continuar participando do estudo)

\section{Observações do Entrevistador}

\begin{tabular}{|l|l|l|l|}
\hline P.48. Tipo de moradia: & \multicolumn{1}{|l|}{ X } & b) Apartamento & \\
\hline a) Casa & & d) Quitinete-estúdio & \\
\hline c) Habitação em cômodo-cortiço & & f) Tenda ou barraca & \\
\hline e) Flat & & h) Outro. Qual? & \\
\hline g) Uso misto &
\end{tabular}

\begin{tabular}{|l|l|l|}
\hline P.49. Tipo de via onde se localiza a residência: & Sim & Não \\
\hline a) Rua asfaltada & $X$ & \\
\hline b) Calçada & $X$ & \\
\hline c) Meio-fio & $X$ & \\
\hline d) Iluminação pública & $X$ & \\
\hline
\end{tabular}

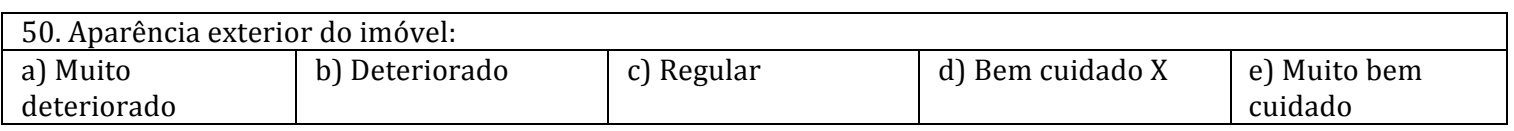

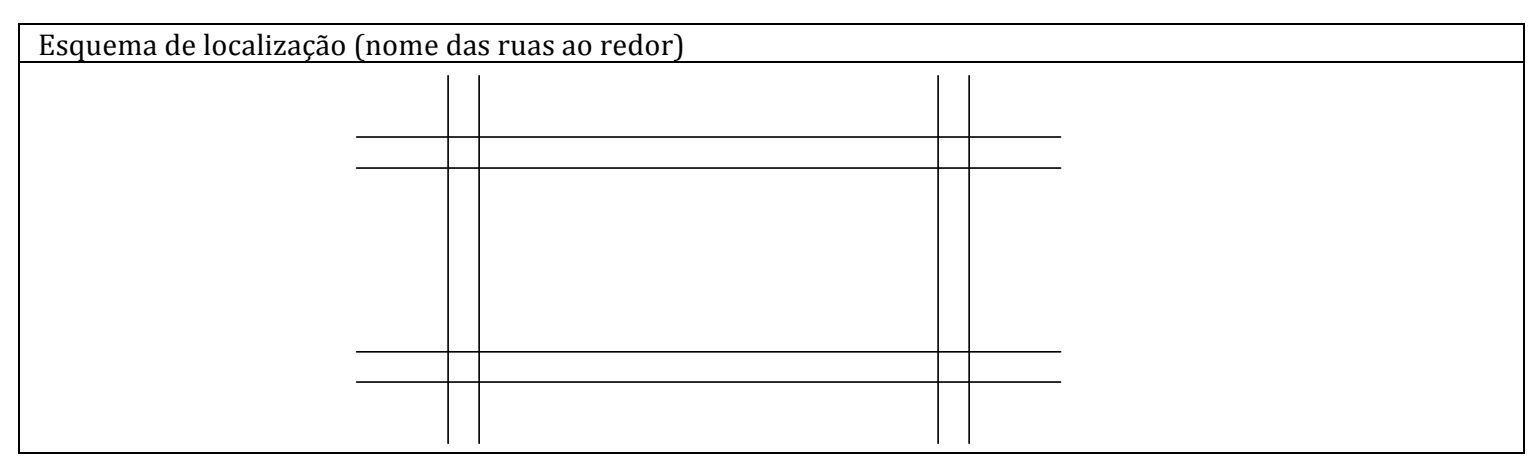




\section{Lista cronológica da legislação em relação a Vila Planalto.}

\begin{tabular}{|c|c|c|c|c|}
\hline $\mathbf{N}^{\mathbf{0}}$ & Legislação & Data & Descrição & Características gerais \\
\hline 1 & $\begin{array}{l}\text { Decreto } \quad \mathrm{N}^{\circ} \\
11.079\end{array}$ & $21 / 04 / 1988$ & $\begin{array}{lrr}\text { Dispõe } & \text { sobre } & \text { o } \\
\text { tombamento } & \text { da } & \text { Vila } \\
\text { Planalto. } & & \end{array}$ & $\begin{array}{l}\text { Decreta o conjunto Vila Planalto como patrimônio histórico } \\
\text { do DF. Destacando o caráter peculiar e bucólico. Devendo } \\
\text { ser preservadas: a mimetização com a paisagem, a área de } \\
\text { tutela non aedificandi, o traçado urbano original, identidade, } \\
\text { linguagem arquitetônica e os espaços de valor simbólico. } \\
\text { Considera crime a destruição, mutilação e alteração dessas } \\
\text { caraterísticas. }\end{array}$ \\
\hline 2 & $\begin{array}{l}\text { Decreto } \quad \mathrm{N}^{\circ} \\
11.080\end{array}$ & $21 / 04 / 1988$ & $\begin{array}{l}\text { Dispõe sobre critérios de } \\
\text { fixação da Vila Planalto }\end{array}$ & $\begin{array}{l}\text { Decreta a fixação da Vila Planalto, considerando a } \\
\text { preservação física e social. Destacando a importância da luta } \\
\text { dos moradores por preservar seu espaço de residência. Os } \\
\text { critérios são: 1) ter domicilio há } 5 \text { anos; 2) Estar no } \\
\text { levantamento socioeconômico de } 1986 \text { (SHIS); 3) Não ser } \\
\text { cessionário, proprietário ou proeminente comprador de outra } \\
\text { residência no DF. Cria o GEAP para implementar o } \\
\text { processo. }\end{array}$ \\
\hline 3 & $\begin{array}{l}\text { Decreto } \quad \mathrm{N}^{\mathrm{o}} \\
11.104\end{array}$ & $12 / 05 / 1988$ & $\begin{array}{l}\text { Dá nova redação ao inciso } \\
\text { VII do art. } 2^{\mathrm{a}} \text { do Decreto } \\
\mathrm{N}^{\mathrm{o}} 11.079\end{array}$ & $\begin{array}{l}\text { Muda a redação, que considerava apenas a restauração de } \\
\text { unidades em ruinas, para permitir a construção de novas } \\
\text { unidade imobiliárias em áreas internas integrando os } \\
\text { acampamentos. }\end{array}$ \\
\hline 4 & $\begin{array}{l}\text { Decreto } \quad \mathrm{N}^{\circ} \\
11.114\end{array}$ & $25 / 05 / 1988$ & $\begin{array}{l}\text { Dispõe sobre alteração do } \\
3^{\circ} \text { artigo do Decreto } \\
\mathrm{N}^{\mathrm{o}} 11.080\end{array}$ & Prorroga por 15 dias o prazo do decreto. \\
\hline 5 & $\begin{array}{l}\text { Decreto } \quad \mathrm{N}^{\circ} \\
11.149\end{array}$ & $23 / 06 / 1988$ & $\begin{array}{l}\text { Dispõe sobre as atribuições } \\
\text { e competências do Grupo } \\
\text { Executivo para } \\
\text { Assentamento }\end{array}$ & $\begin{array}{l}\text { Decreta a composição do GEAP que será escolhida pelo } \\
\text { Governador e integrada por } 5 \text { representantes do Poder } \\
\text { Executivo, } 1 \text { da TERRACAP, } 1 \text { do DePHA, } 3 \text { do Conselho } \\
\text { Comunitário da Vila Planalto. }\end{array}$ \\
\hline 6 & $\begin{array}{l}\text { Decreto } \quad \mathrm{N}^{\circ} \\
11.155\end{array}$ & $29 / 06 / 1988$ & $\begin{array}{l}\text { Dispõe sobre alteração do } \\
\text { artigo } 7^{\circ} \text { do Decreto } \mathrm{N}^{\circ} \\
11.080\end{array}$ & Altera os critérios de fixação da Vila Planalto. \\
\hline 7 & $\begin{array}{ll}\text { Decreto } & \mathrm{N}^{\circ} \\
11.196 & \\
\end{array}$ & $11 / 08 / 1988$ & $\begin{array}{l}\text { Designa membros para } \\
\text { compor o GEAP }\end{array}$ & $\begin{array}{l}\text { Muda os } 5 \text { integrantes do GEAP que representam ao } \\
\text { Executivo. }\end{array}$ \\
\hline 8 & $\begin{array}{l}\text { Decreto } \quad \mathrm{N}^{\circ} \\
11.311\end{array}$ & $25 / 11 / 1988$ & $\begin{array}{l}\text { Designa membros para } \\
\text { compor o GEAP }\end{array}$ & $\begin{array}{l}\text { Muda os } 3 \text { integrante do GEAP que representam ao } \\
\text { Conselho Comunitário. }\end{array}$ \\
\hline 9 & $\begin{array}{ll}\text { Decreto } & \mathrm{N}^{\circ} \\
11.312 & \\
\end{array}$ & $25 / 11 / 1988$ & $\begin{array}{l}\text { Dispõe sobre a composição } \\
\text { do GEAP }\end{array}$ & $\begin{array}{l}\text { Designa o arquiteto Olavo Thadeu como coordenador do } \\
\text { GEAP. }\end{array}$ \\
\hline 10 & $\begin{array}{l}\text { Decreto } \quad \mathrm{N}^{\circ} \\
12.246\end{array}$ & $05 / 03 / 1990$ & $\begin{array}{l}\text { Dispõe sobre material de } \\
\text { construção a ser empregado } \\
\text { no Conjunto da Vila } \\
\text { Planalto }\end{array}$ & $\begin{array}{l}\text { Decreta o uso de madeira nas restaurações, acréscimos ou } \\
\text { novas edificações. Admite uso de alvenaria apenas em áreas } \\
\text { húmidas (não em fachadas aparentes) e na base do muro } \\
\text { perimetral (até } 30 \mathrm{~cm} \text {. de altura). }\end{array}$ \\
\hline 11 & $\begin{array}{l}\text { Decreto } \quad \mathrm{N}^{\mathrm{o}} \\
12.247\end{array}$ & $05 / 03 / 1990$ & $\begin{array}{l}\text { Aprova o regulamento para } \\
\text { a regularização das } \\
\text { unidades imobiliárias do } \\
\text { conjunto da Vila Planalto. }\end{array}$ & $\begin{array}{l}\text { Regulamento: 1)Morador cadastrado pela SHIS (1986/87) } \\
\text { deve residir por 5 anos, mínimo. 2)Documento } \\
\text { comprovatório fornecido pela TERRACAP, CEB, ou } \\
\text { CAESB. 3)Cabe a GEAP a aprovação. 4)Regularização } \\
\text { imobiliária por Contrato de Concessão de Uso de } 25 \text { anos } \\
\text { prorrogável. 5)Pagamento de Taxa de ocupação (50\% } \\
\text { desconto para renda familiar menor o igual a } 3 \mathrm{SM}) \text {. } \\
\text { 6)Cumprimento das NGB. }\end{array}$ \\
\hline 12 & $\begin{array}{l}\text { Decreto } \quad \mathrm{N}^{\circ} \\
12.578\end{array}$ & $09 / 08 / 1990$ & $\begin{array}{l}\text { Altera o artigo } 2^{\circ} \text { do } \\
\text { Decreto } \mathrm{N}^{\circ} 11.149\end{array}$ & $\begin{array}{l}\text { Diminui o numero de membros do GEAP para } 9 \text { e designa } \\
\text { seus integrantes. }\end{array}$ \\
\hline 13 & $\begin{array}{l}\text { NGB } \\
163,164,165 / \\
90\end{array}$ & 1990 & $\begin{array}{l}\text { Dispõe sobre as normas de } \\
\text { gabarito e os usos } \\
\text { permitidos na Vila Planalto }\end{array}$ & \\
\hline 14 & $\begin{array}{l}\text { Decreto } \quad \mathrm{N}^{\circ} \\
13.184\end{array}$ & $15 / 05 / 1991$ & $\begin{array}{l}\text { Altera o inciso I do } \\
\text { parágrafo único do artigo } \\
1^{\circ} \text { do Decreto } \mathrm{N}^{\circ} 12.246\end{array}$ & $\begin{array}{l}\text { Altera o material de construção a ser empregado no conjunto } \\
\text { da vila planalto. Permitindo uso de alvenaria nas áreas } \\
\text { internas das unidades habitacionais, desde } \\
\text { que não se localizem nas fachadas aparentes. }\end{array}$ \\
\hline 15 & $\begin{array}{ll}\text { Decreto } & \mathrm{N}^{\circ} \\
13.326\end{array}$ & $18 / 07 / 1991$ & $\begin{array}{l}\text { Altera o art. } 9^{\circ} \text { do Decreto } \\
\mathrm{N}^{\circ} 11.149()\end{array}$ & $\begin{array}{l}\text { Modifica a composição do GEAP incorporando um } \\
\text { coordenador adjunto. }\end{array}$ \\
\hline 16 & $\begin{array}{ll}\text { Decreto } & \mathrm{N}^{\circ} \\
13.369 & \\
\end{array}$ & $09 / 08 / 1991$ & Revoga Decreto $\mathrm{N}^{\circ} 13.326$ & Elimina a modificação à composição do GEAP. \\
\hline 17 & NGB 58/91 & 1991 & $\begin{array}{l}\text { Dispõe sobre as normas de } \\
\text { gabarito e os usos } \\
\text { permitidos na Av. Pacheco } \\
\text { Fernandes na Vila Planalto }\end{array}$ & \\
\hline 18 & $\begin{array}{ll}\text { Decreto } & \mathrm{N}^{\circ} \\
13.751 & \end{array}$ & $29 / 01 / 1992$ & $\begin{array}{l}\text { Dispõe sobre a necessidade } \\
\text { uniformizar os critérios de } \\
\text { habilitação de candidatos à } \\
\text { moradia no DF }\end{array}$ & $\begin{array}{l}\text { Decreta a adoção das normas do Regulamento do decreto } \\
\mathrm{N}^{\circ} 10.056 \text { e começam a reger para o processo de fixação da } \\
\text { Vila Planalto. Permite que proprietários de outras unidades } \\
\text { imobiliárias possam receber a concessão de uso na Vila. }\end{array}$ \\
\hline
\end{tabular}




\begin{tabular}{|c|c|c|c|c|}
\hline 19 & $\begin{array}{ll}\text { Decreto } & \mathrm{N}^{\circ} \\
13.899 & \\
\end{array}$ & $14 / 04 / 1992$ & $\begin{array}{l}\text { Prorroga a vigência do } \\
\text { Decreto } \mathrm{N}^{\circ} 12.247\end{array}$ & $\begin{array}{l}\text { Mais } 90 \text { dias de vigência ao regulamento de Regularização } \\
\text { das Unidades Imobiliárias. }\end{array}$ \\
\hline 20 & Lei $\mathrm{N}^{\circ} 271$ & $29 / 05 / 1992$ & $\begin{array}{l}\text { Autoriza o Poder Executivo } \\
\text { a fixar moradores pioneiros } \\
\text { da Vila Planalto }\end{array}$ & $\begin{array}{l}\text { Autoriza ao Poder Executivo a fixar os moradores Pioneiros } \\
\text { da Vila Planalto segundo requisitos do decreto } N^{\circ} 11.080 \text {. } \\
\text { Incorpora à fixação } 248 \text { famílias de filhos de pioneiros e } \\
\text { moradores que sempre residiram no local e não foram } \\
\text { cadastrados no levantamento realizado em } 1986 / 87 \text { SHIS. } \\
\text { Autor: Fernando Naves (PPB). }\end{array}$ \\
\hline 21 & $\begin{array}{ll}\text { Decreto } & \mathrm{N}^{0} \\
14.053 & \end{array}$ & $21 / 07 / 1992$ & $\begin{array}{l}\text { Mantém a composição do } \\
\text { GEAP }\end{array}$ & $\begin{array}{l}\text { Além de manter os representantes do GEAP prorroga até } \\
21 / 01 / 1993 \text { o prazo para fixação. Da à Administração } \\
\text { Regional do Plano Piloto a fiscalização das NGB. }\end{array}$ \\
\hline 22 & $\begin{array}{l}\text { Decreto } \quad \mathrm{N}^{\circ} \\
14.455\end{array}$ & $07 / 12 / 1992$ & $\begin{array}{l}\text { Renova disposição do } \\
\text { Decreto } \mathrm{N}^{\circ} 11.149\end{array}$ & $\begin{array}{l}\text { Renova o mandato dos membros do Conselho Comunitário } \\
\text { da Vila Planalto até } 21 / 10 / 1993 \text {. }\end{array}$ \\
\hline 23 & $\begin{array}{ll}\text { Decreto } & \mathrm{N}^{\circ} \\
14.586 & \end{array}$ & $21 / 01 / 1993$ & $\begin{array}{l}\text { Prorroga prazo do Decreto } \\
\mathrm{N}^{\circ} 11.080\end{array}$ & Prorrogado até 31 de janeiro de 1993. \\
\hline 24 & $\begin{array}{ll}\text { Decreto } & \mathrm{N}^{\circ} \\
14.663 & \end{array}$ & $05 / 04 / 1993$ & $\begin{array}{l}\text { Dispõe sobre a extinção do } \\
\text { GEAP }\end{array}$ & $\begin{array}{l}\text { Elimina o GEAP e entrega à Administração Regional de } \\
\text { Brasília (RA-1) a responsabilidade pela Vila Planalto, em } \\
\text { infraestrutura urbana, ações relativas à preservação e } \\
\text { parcelamento urbano. Processos relativos à fixação passam a } \\
\text { ser julgadas pela SHIS. }\end{array}$ \\
\hline 25 & $\begin{array}{ll}\text { Decreto } & \mathrm{N}^{\circ} \\
15.542 & \end{array}$ & $29 / 03 / 1994$ & $\begin{array}{l}\text { Prorroga o prazo para a } \\
\text { conclusão dos atos de que } \\
\text { trata o artigo } 1^{\circ} \text { do Decreto } \\
\mathrm{N}^{\circ} 15.370\end{array}$ & $\begin{array}{l}\text { Dá mais } 60 \text { dias o prazo para a SHIS julgar os processo } \\
\text { relativa à fixação da Vila Planalto ainda pendentes. }\end{array}$ \\
\hline 26 & $\begin{array}{ll}\text { Decreto } & \mathrm{N}^{\circ} \\
15.692 & \end{array}$ & $01 / 06 / 1994$ & $\begin{array}{l}\text { Prorroga o prazo para a } \\
\text { conclusão dos atos de que } \\
\text { trata o artigo } 1^{\circ} \text { do Decreto } \\
\mathrm{N}^{\circ} 15.542\end{array}$ & Outros 60 dias para julgar processo relativos à fixação. \\
\hline 27 & $\begin{array}{ll}\text { Decreto } & \mathrm{N}^{\circ} \\
15.817 & \end{array}$ & $05 / 08 / 1994$ & $\begin{array}{l}\text { Prorroga o prazo para a } \\
\text { conclusão dos atos de que } \\
\text { trata o artigo } 1^{\circ} \text { do Decreto } \\
\mathrm{N}^{\circ} 15.542\end{array}$ & Mais 60 dias para a conclusão da fixação. \\
\hline 28 & $\begin{array}{ll}\text { Decreto } & \mathrm{N}^{\circ} \\
16.226 & \end{array}$ & $28 / 12 / 1994$ & $\begin{array}{l}\text { Aprova o projeto referente } \\
\text { ao conjunto tombado da } \\
\text { Vila Planalto. Memorial } \\
\text { descritivo MDE-90/90, } \\
\text { plantas URB-90/90 e nas } \\
\text { NGB 90/90, 163-164- } \\
\text { 165/90. Segundo princípios } \\
\text { apresentados pelo GT- } \\
\text { Brasília de } 04 / 1987 \text {. }\end{array}$ & $\begin{array}{l}\text { Memorial destaca a forma interiorizada e a vegetação } \\
\text { exuberante. A malha urbana se caracteriza pelas diferenças } \\
\text { entre os acampamentos e a estrutura viária tem sua própria } \\
\text { hierarquização. Reconhece uma relação entre o tamanho do } \\
\text { imóvel e o nível de renda. Dinâmica urbana favorecida pela } \\
\text { diversidade de lotes, usos e pela relação direta do espaço } \\
\text { privado com o público. Classifica três categorias: } \\
\text { 1)Edificações de Preservação Rigorosa, 2)Edificações de } \\
\text { interesse histórico, 3)Edificações remanescentes. Determina } \\
\text { afastamento mínimo (1,5m), taxa de máx. de ocupação (30- } \\
25 \%), \mathrm{N}^{\circ} \text { pavimentos (1), altura }(4,5 \mathrm{~m})\end{array}$ \\
\hline 29 & $\begin{array}{l}\text { Lei } \mathrm{N}^{\circ} \\
1.060 / 1996\end{array}$ & $30 / 04 / 1996$ & $\begin{array}{l}\text { Dispõe sobre a concessão } \\
\text { de título de transferência de } \\
\text { posse e domínio pelo GDF, } \\
\text { na Vila Planalto. }\end{array}$ & $\begin{array}{l}\text { Tem direito à aquisição das unidades: 1)moradores } \\
\text { cadastrados pela SHIS em } 1986 \text { e } 1987 ; 2 \text { ) moradores que } \\
\text { receberam lotes por transferência e inclusões, formalizadas } \\
\text { GEAP entre } 1989 \text { e 1994; 3) filhos de pioneiros, de acordo } \\
\text { com a Lei No271/1992; 4) moradores de } 7 \text { unidades do } \\
\text { acampamento EBE. A concessão será por termo de } \\
\text { compromisso de compra e venda, com cláusula de fixação de } \\
\text { prazo de seis anos para construção e de proibição da } \\
\text { transferência do imóvel antes do cumprimento de todas as } \\
\text { obrigações contratuais. Faculta ao beneficiário a concessão } \\
\text { do direito real de uso, com opção pela compra, a qualquer } \\
\text { tempo. Autor: Luiz Estevão (PP/PMDB)) e Marcos Arruda } \\
\text { (PRTB). } \\
\text { Declarada Inconstitucional pelo TJDFT. }\end{array}$ \\
\hline 30 & Lei $\mathrm{N}^{\circ} 1.231$ & $21 / 10 / 1996$ & $\begin{array}{l}\text { Altera normas de } \\
\text { edificação dos lotes que } \\
\text { menciona, situados na Vila } \\
\text { Planalto }\end{array}$ & $\begin{array}{l}\text { As novas NGB valem para os usos residencial-comercial, } \\
\text { misto e institucional. Permite: construção de subsolo, } \\
\text { utilização de materiais metálicos, telhas de cerâmica, cerco } \\
\text { de máx. } 2 \mathrm{~m} \text {. de altura. Autores: Marco Arruda (PRTB) e } \\
\text { Luiz Estevão (PP/PMDB). }\end{array}$ \\
\hline 31 & Lei $\mathrm{N}^{\circ} 1.744$ & $09 / 09 / 1997$ & $\begin{array}{l}\text { Dispõe sobre a remissão } \\
\text { das multas relativas a } \\
\text { infrações ao Código de } \\
\text { Obras e Edificações de } \\
\text { Brasília na Vila Planalto }\end{array}$ & $\begin{array}{l}\text { Concede um perdão para as multas incidentes sobre os } \\
\text { imóveis que infringiram o Código de Obras. Autor: Tadeu } \\
\text { Filippelli (PMDB). }\end{array}$ \\
\hline 32 & $\begin{array}{l}\text { Lei } \mathrm{N}^{\circ} \\
1.742 / 1997\end{array}$ & $23 / 10 / 1997$ & $\begin{array}{l}\text { Autoriza a companhia } \\
\text { imobiliária de Brasília } \\
\text { (TERRACAP) a alienar } \\
\text { lotes residenciais em favor } \\
\text { das famílias residentes no } \\
\text { Anexo III do Brasília } \\
\text { Palace Hotel e adjacências. }\end{array}$ & $\begin{array}{l}\text { São beneficiárias famílias participantes da pesquisa } \\
\text { socioeconômica realizada em 11/1995 pelo núcleo da } \\
\text { circunscrição da Vila Planalto em conjunto com a Divisão } \\
\text { Regional de Desenvolvimento Social da Região } \\
\text { Administrativa de Brasília, pelo Instituto de } \\
\text { Desenvolvimento Habitacional do Distrito Federal (IDHAB). } \\
\text { Autor: Rodrigo Rollemberg (PSB). }\end{array}$ \\
\hline 33 & $\begin{array}{ll}\text { Decreto } & \mathrm{N}^{\circ} \\
19.082 & \\
\end{array}$ & $11 / 03 / 1998$ & $\begin{array}{l}\text { Aprova Projeto Urbanístico } \\
\text { na RA-I de Brasília }\end{array}$ & $\begin{array}{l}\text { Aprova o projeto urbanístico de parcelamento nas normas } \\
\text { 90/90 de } 1994\end{array}$ \\
\hline
\end{tabular}




\begin{tabular}{|c|c|c|c|c|}
\hline 34 & Lei No 1.933 & $05 / 05 / 1998$ & $\begin{array}{lrr}\text { Cria o Setor } & \text { de } \\
\text { Microempresas da } \text { Vila } \\
\text { Planalto na RA-I }\end{array}$ & $\begin{array}{l}\text { O Setor de Microempresas da Vila Planalto será definida } \\
\text { pelo Poder Executivo no prazo de noventa dias, realizando: } \\
\text { audiência pública, estudo de impacto ambiental e, seguindo } \\
\text { as diretrizes do PDOT e regras de tombamento do conjunto. } \\
\text { Autor: Marcos Arruda (PRTB) }\end{array}$ \\
\hline 35 & Lei N $^{\circ} 2.040$ & $28 / 07 / 1998$ & $\begin{array}{l}\text { Dispõe sobre a criação da } \\
\text { Casa da Cultura da Vila } \\
\text { Planalto na RA-I }\end{array}$ & $\begin{array}{l}\text { Cria a Casa da Cultura destinada ao uso institucional, } \\
\text { devendo ser edificada na Área Especial 7, Rua 3, } \\
\text { Acampamento Tamboril. A construção deve manter a } \\
\text { tipologia original descrito no tombamento. } \\
\text { Autor: Tadeu Filippelli (PMDB) }\end{array}$ \\
\hline 36 & $\begin{array}{l}\text { Lei } 2.384 / 1999 \\
\mathrm{~N}^{\mathrm{o}}\end{array}$ & $09 / 03 / 1999$ & $\begin{array}{l}\text { Cria no GDF a } \\
\text { subministração regional da } \\
\text { Vila Planalto }\end{array}$ & $\begin{array}{l}\text { O Núcleo da Circunscrição Administrativa da Vila Planalto } \\
\text { passa a denominar-se Sub-administração Regional da Vila } \\
\text { Planalto. Autor: Poder Executivo }\end{array}$ \\
\hline 37 & $\begin{array}{ll}\text { Decreto } & \mathrm{N}^{\mathrm{o}} \\
29.652 & \end{array}$ & $28 / 10 / 2008$ & $\begin{array}{l}\text { Cria Grupo de Trabalho } \\
\text { para elaborar um plano de } \\
\text { ação referente à Vila } \\
\text { Planalto. }\end{array}$ & $\begin{array}{l}\text { O GT é composto por: SEDUMA-DF (3); Coordenadoria das } \\
\text { Cidades da SEG-DF (1); AGEFIS (1); SEC-DF (1); } \\
\text { Administração Regional de Brasília (1); Subsecretaria de } \\
\text { Defesa do Solo e da Água da SESP-DF; TERRACAP; } \\
\text { Companhia de Saneamento Ambiental do DF; CEB; } \\
\text { BRASILIATUR. }\end{array}$ \\
\hline 38 & $\begin{array}{ll}\text { Decreto } & \mathrm{N}^{\circ} \\
31.064 & \end{array}$ & $23 / 11 / 2009$ & $\begin{array}{lr}\text { Cria o Grupo } & \text { Executivo } \\
\text { responsável } & \text { pela } \\
\text { implantação do Plano de } \\
\text { Ação para a Vila Planalto. }\end{array}$ & $\begin{array}{l}\text { O Grupo Executivo tem a atribuição de implantar e } \\
\text { coordenar a regularização proposta pelo Grupo de Trabalho } \\
\text { segundo o Decreto No29.652/2008. O Grupo Executivo é } \\
\text { composto por: TERRACAP; SEG-DF; SEDUMA-DF; } \\
\text { DePHA da SEC-DF; SUDESA da SSP-DF; AGEFIS; } \\
\text { Administração Regional de Brasília; BRASILIATUR. }\end{array}$ \\
\hline 39 & Lei $\mathrm{N}^{0} 5.135$ & $12 / 07 / 2013$ & $\begin{array}{l}\text { Autoriza ao Poder } \\
\text { Executivo de alienar as } \\
\text { unidade imobiliárias na } \\
\text { Vila Planalto }\end{array}$ & $\begin{array}{l}\text { Projeto do GDF que se autoriza a alienar as unidades } \\
\text { imobiliárias localizadas dentro da poligonal de tombamento } \\
\text { e no acampamento EBE. Por doação (para fixados), venda } \\
\text { direta, (para ocupantes) licitação (ocupantes ou outros). }\end{array}$ \\
\hline
\end{tabular}




\section{Lista cronológica dos projetos de lei em relação a Vila Planalto.}

\begin{tabular}{|c|c|c|c|c|}
\hline $\mathbf{N}^{\mathbf{0}}$ & Legislação & Data & Descrição & Características gerais \\
\hline 1 & $\begin{array}{ll}\mathrm{PL} & \mathrm{N}^{\circ} \\
339 / 1992 & \end{array}$ & $28 / 02 / 1992$ & $\begin{array}{l}\text { Autoriza o poder executivo a fixar } \\
\text { moradores pioneiros da Vila Planalto }\end{array}$ & $\begin{array}{l}\text { Autor: Fernando Naves (PPB). } \\
\text { Situação: Promulgado. }\end{array}$ \\
\hline 2 & $\begin{array}{l}\mathrm{PL} \\
1.299 / 1994\end{array}$ & $15 / 03 / 1994$ & $\begin{array}{l}\text { Institui o direito à escritura definitiva } \\
\text { dos lotes semi-urbanizados da Vila } \\
\text { Planalto aos seus legítimos } \\
\text { concessionários. }\end{array}$ & $\begin{array}{l}\text { Autor: Tadeu Roriz (PPB) } \\
\text { Situação: Arquivado }\end{array}$ \\
\hline 3 & $\begin{array}{ll}\mathrm{PL} & \mathrm{N}^{\circ} \\
427 / 1995 & \end{array}$ & $06 / 06 / 1995$ & $\begin{array}{l}\text { Dispõe sobre a concessão de título de } \\
\text { domínio pelo GDF, na Vila Planalto. }\end{array}$ & $\begin{array}{l}\text { Autor: Luiz Estevão (PP/PMDB)* (mandato } \\
\text { cassado em 2000) e Marco Arruda (PRTB). } \\
\text { Situação: Promulgada. }\end{array}$ \\
\hline 4 & $\begin{array}{l}\mathrm{PL} \mathrm{N}^{\mathrm{o}} \\
1.064 / 1995\end{array}$ & $15 / 12 / 1995$ & $\begin{array}{l}\text { Autoriza a TERRACAP alienar lotes } \\
\text { residenciais a ocupantes do Anexo III } \\
\text { do Brasília Palace Hotel e adjacências. }\end{array}$ & $\begin{array}{l}\text { Beneficia as famílias participantes da pesquisa } \\
\text { socioeconômica realizada em novembro de } 1995 \\
\text { pelo núcleo da circunscrição da Vila Planalto. } \\
\text { Autor: Rodrigo Rollemberg (PSB). } \\
\text { Situação: Promulgada. }\end{array}$ \\
\hline 6 & $\begin{array}{l}\mathrm{PL} \\
1.188 / 1996\end{array}$ & $28 / 02 / 1996$ & $\begin{array}{l}\text { Dispõe sobre a criação de áreas para } \\
\text { instalação das Associações de } \\
\text { Moradores nas quadras residenciais do } \\
\text { Plano Piloto e na Vila Planalto. }\end{array}$ & $\begin{array}{l}\text { Autor: Marcos Arruda (PRTB) } \\
\text { Situação: Arquivado }\end{array}$ \\
\hline 7 & $\begin{array}{l}\mathrm{PL} \\
1.494 / 1996\end{array}$ & $18 / 04 / 1996$ & $\begin{array}{l}\text { Autoriza o Poder Executivo a criar a } \\
\text { Sub-Administração Regional da Vila } \\
\text { Planalto }\end{array}$ & $\begin{array}{l}\text { Autor: César Lacerda (PSDB) } \\
\text { Situação: Arquivado. }\end{array}$ \\
\hline 8 & $\begin{array}{l}\mathrm{PL} \\
1.776 / 1996\end{array}$ & $17 / 06 / 1996$ & $\begin{array}{l}\text { Reserva área para atender filhos de } \\
\text { pioneiros da Vila Planalto. }\end{array}$ & $\begin{array}{l}\text { Autores: Luiz Estevão (PP/PMDB) e Marcos } \\
\text { Arruda (PRTB). } \\
\text { Situação: Arquivado }\end{array}$ \\
\hline 9 & $\begin{array}{l}\mathrm{PL} \\
1.887 / 1996\end{array}$ & $01 / 08 / 1996$ & $\begin{array}{l}\text { Dispõe sobre o registro imobiliário dos } \\
\text { lotes da Vila Planalto. }\end{array}$ & $\begin{array}{l}\text { Autor: Tadeu Filippelli (PMDB) } \\
\text { Situação: Arquivado }\end{array}$ \\
\hline 13 & $\begin{array}{l}\mathrm{PL} \\
2.318 / 1996\end{array}$ & $17 / 10 / 1996$ & $\begin{array}{l}\text { Autoriza o GDF destinar } 70 \% \text { das áreas } \\
\text { reservadas para comercio como } \\
\text { prioritárias para empresários residentes } \\
\text { da Vila Planalto }\end{array}$ & $\begin{array}{l}\text { Programa de Desenvolvimento Econômico do } \\
\text { DF (PRODECON) } \\
\text { Autor: Tadeu Filippelli (PMDB) } \\
\text { Situação: Arquivado }\end{array}$ \\
\hline 14 & $\begin{array}{ll}\mathrm{PLC} & \mathrm{N}^{\circ} \\
650 / 1998 & \\
\end{array}$ & 1988 & $\begin{array}{l}\text { Permite a construção do segundo } \\
\text { pavimento na Vila Planalto }\end{array}$ & $\begin{array}{l}\text { Autor: Tadeu Filippelli. } \\
\text { Situação: Arquivado. }\end{array}$ \\
\hline 15 & $\begin{array}{ll}\text { PLC } & \mathrm{N}^{\circ} \\
411 / 1999 & \end{array}$ & $02 / 11 / 1999$ & $\begin{array}{l}\text { Determina a destinação de uso } \\
\text { institucional para atividade culto na } \\
\text { Vila Planalto. }\end{array}$ & $\begin{array}{l}\text { Prevê o levantamento e identificação das igrejas } \\
\text { atuando há mais de } 10 \text { ano na Vila Planalto para } \\
\text { ser destinatárias de lotes. Autor: Wasny de } \\
\text { Roure. Situação: Arquivado. }\end{array}$ \\
\hline 16 & $\begin{array}{ll}\text { PLC } & N^{\circ} \\
848 / 2000 & \end{array}$ & $21 / 11 / 2000$ & $\begin{array}{l}\text { Dispõe sobre a alteração de destinação } \\
\text { da área na Vila Planalto }\end{array}$ & $\begin{array}{l}\text { Área do Acampamento Pacheco Fernandes, da } \\
\text { passaria a ser destinada ao uso institucional, } \\
\text { atividade culto. Autor: José Rajão (PMDB). } \\
\text { Situação: arquivada. }\end{array}$ \\
\hline 17 & $\begin{array}{ll}\text { PLC } & N^{\circ} \\
893 / 2000 & \end{array}$ & $18 / 12 / 2000$ & $\begin{array}{l}\text { Dispõe sobre a desafetação de área } \\
\text { pública de uso comum do povo, na Vila } \\
\text { Planalto. }\end{array}$ & $\begin{array}{l}\text { Desafeta a área localizada na Rua } 7, \\
\text { Acampamento Pacheco Fernandes. A área } \\
\text { desafetada é destinada a atividades religiosas } \\
\text { especificamente para a construção da Paróquia } \\
\text { Nossa Senhora do Rosário de Pompéia. Autor: } \\
\text { Daniel Marques (PMDB). } \\
\text { Situação: Arquivado. }\end{array}$ \\
\hline
\end{tabular}




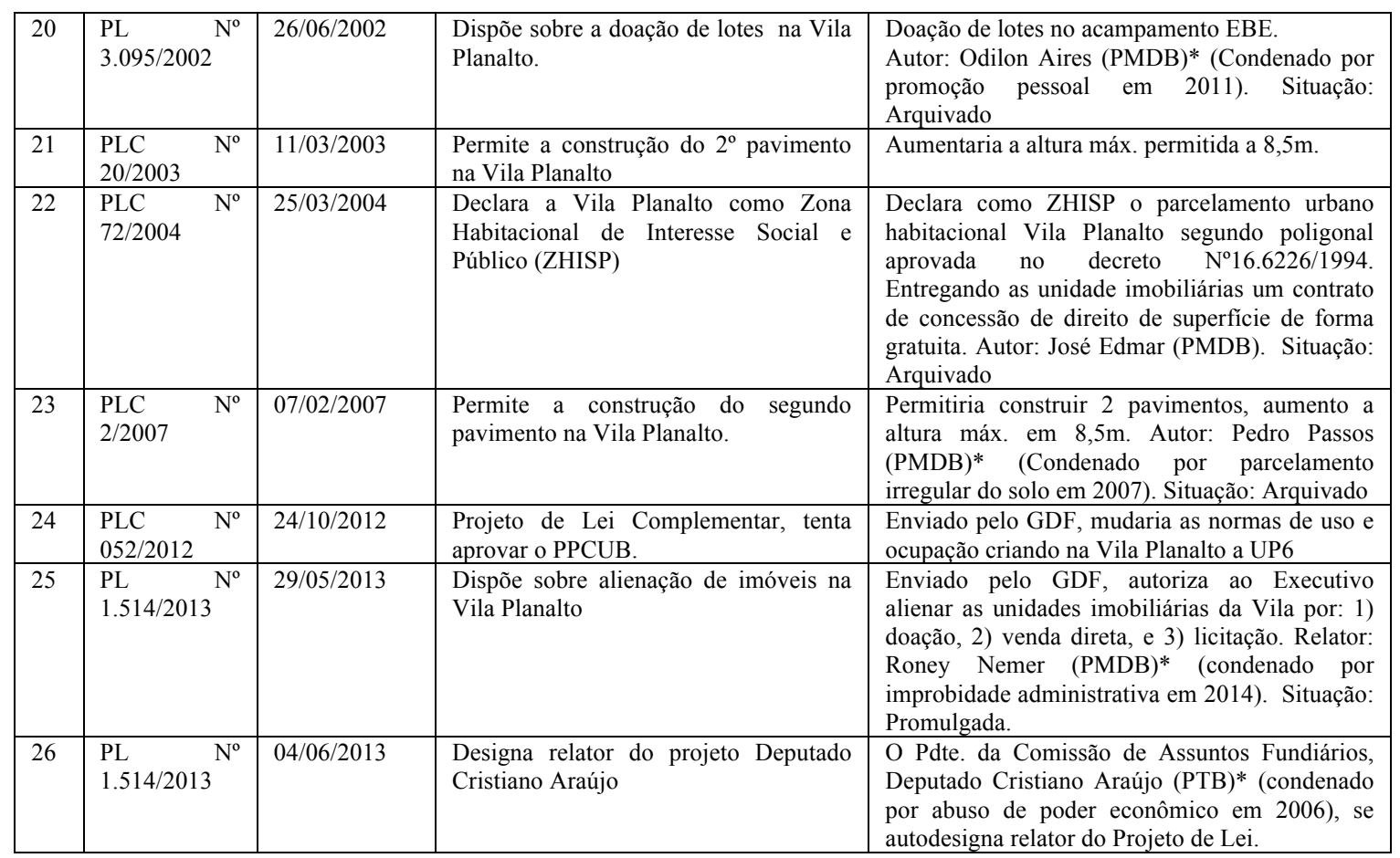




\section{Lista cronológica dos processos jurídicos e documentos legais em relação a Vila Planalto.}

\begin{tabular}{|c|c|c|c|c|}
\hline $\mathbf{N}^{\mathbf{0}}$ & Acórdão & Data & Descrição & Características gerais \\
\hline 1 & $\begin{array}{l}\text { Acórdão } \mathrm{N}^{\circ} \\
127170\end{array}$ & $27 / 04 / 2000$ & $\begin{array}{l}\text { Apelação cível. A TERRACAP } \\
\text { ajuizou morador de Vila pedindo a } \\
\text { demolição de muro de alvenaria em } \\
\text { desacordo com a normativa }\end{array}$ & $\begin{array}{l}\text { Resolve que a empresa carece de legitimidade para } \\
\text { ação demolitória já que sua competência se restringe } \\
\text { às concessões de uso, com qual não há } \\
\text { descumprimento. (casal, Rua dos Engenheiro, Ac. } \\
\text { Pacheco Fernandes). }\end{array}$ \\
\hline 2 & $\begin{array}{l}\text { Acórdão } \mathrm{N}^{\circ} \\
137107\end{array}$ & $27 / 11 / 2000$ & $\begin{array}{l}\text { Apelação Cível e Remessa de } \\
\text { Ofício. GDF solicita reintegração de } \\
\text { posse de dois lotes na Vila Planalto. } \\
\text { O GDF Alega que invadiram parte } \\
\text { dos lotes vizinhos e possuem mais } \\
\text { de dois imóveis no DF. }\end{array}$ & $\begin{array}{l}\text { Reconhece que o lote aumentou mas assegura a } \\
\text { posse do imóvel dos moradores nos termos } \\
\text { originais, sem abranger a área dos lotes } 22 \text { e } 25 \text {. } \\
\text { Nega provimento de reintegração de posse (Av. JK, } \\
\text { Ac. Rabelo, Casa } 22 \text {. }\end{array}$ \\
\hline 3 & $\begin{array}{l}\text { Acórdão } \mathrm{N}^{\circ} \\
137108\end{array}$ & $09 / 05 / 2001$ & $\begin{array}{l}\text { Ação Rescisória. Demandante } \\
\text { permutou seu lote com outra } \\
\text { moradora na Vila Planalto pagando } \\
\text { R } \$ 5 \text { mil de diferença e construí uma } \\
\text { casa. Demanda à filha da pessoa } \\
\text { com quem permutou. }\end{array}$ & $\begin{array}{l}\text { A demandada, que adquiriu o lote de sua mãe e } \\
\text { nunca morou no local, desconhece a permuta } \\
\text { havendo ganhado em uma ação anterior na justiça } \\
\text { falsificando provas. Se determina que a demandante } \\
\text { seja reintegrada na posse do imóvel. }\end{array}$ \\
\hline 4 & $\begin{array}{l}\text { Acordão } \mathrm{N}^{\circ} \\
157992\end{array}$ & $20 / 06 / 2002$ & $\begin{array}{l}\text { Agravo de Instrumento. Se nega } \\
\text { provimento a pedido suspensão de } \\
\text { reintegração de posse. }\end{array}$ & $\begin{array}{l}\text { Se negou a solicitude do ocupante irregular do lote } \\
\text { quem pedia a suspensão de reintegração alegando } \\
\text { haver edificado. Se reconhece a posse a quem tem a } \\
\text { concessão de uso da GEAP. (Rua 4, lote } 19 \text {, Ac. } \\
\text { Pacheco F.) }\end{array}$ \\
\hline 5 & $\begin{array}{l}\text { Acordão } \mathrm{N}^{\circ} \\
171612\end{array}$ & $17 / 03 / 2003$ & $\begin{array}{l}\text { Agravo de Instrumento. Morador do } \\
\text { Setor de Chácaras solicita } \\
\text { suspensão de liminar para demolir } \\
\text { seu imóvel. }\end{array}$ & $\begin{array}{l}\text { Agravante alega as terras ser uma herança. A justiça } \\
\text { nega provimento para conter a devastação da área } \\
\text { (Chácara 13). }\end{array}$ \\
\hline 6 & $\begin{array}{l}\text { Acordão } \mathrm{N}^{\circ} \\
216834\end{array}$ & $04 / 04 / 2005$ & $\begin{array}{l}\text { Apelação Cível e Remessa de } \\
\text { Ofício. GDF apela contra ocupantes } \\
\text { do Setor de Chácaras. Apelados } \\
\text { alegam morar há } 42 \text { anos no local } \\
\text { sendo notificados para demolir suas } \\
\text { casas. }\end{array}$ & $\begin{array}{l}\text { Parcialmente provido. Se concede a proteção } \\
\text { possesiva em favor dos imóveis já edificados e não } \\
\text { das obras em construção. Justiça reconhece } \\
\text { jurisprudência que tolera construções em áreas } \\
\text { publicas por falta de fiscalização. Declara que terras } \\
\text { propriedade da TERRACAP são bens dominicais e } \\
\text { não publicas, podendo ser desafetadas. }\end{array}$ \\
\hline 7 & $\begin{array}{l}\text { Acórdão } \mathrm{N}^{\circ} \\
221296\end{array}$ & $19 / 05 / 2005$ & $\begin{array}{l}\text { Apelação Cível. Processo anulatório } \\
\text { de ato administrativo de } \\
\text { reintegração de posso. }\end{array}$ & $\begin{array}{l}\text { Apelo improvido para pedido de reintegração de } \\
\text { posse da TERRACAP contra residente do Ac. } \\
\text { Rabelo (desde 1974). O decreto } \mathrm{N}^{\circ} 11.080 \text { que } \\
\text { estabelecia que um dos requisitos para a fixação dos } \\
\text { moradores era não ser ou não ter sido cessionário, } \\
\text { promitente comprador de unidade residencial no } \\
\text { DF, foi revogado pelo decreto } \mathrm{N}^{\circ} 13.751 / 92 . \\
\text { Portanto, ter sido proprietário de dois imóveis não } \\
\text { constitui impedimento para a seleção do seu nome. }\end{array}$ \\
\hline 8 & $\begin{array}{l}\text { Acórdão } \mathrm{N}^{\circ} \\
242989 \\
\text { ADI } \\
2005.00 .2 .00 \\
2473-2\end{array}$ & $14 / 02 / 2006$ & $\begin{array}{l}\text { ADIN contra Lei Distrital } \\
\mathrm{N}^{0} 1.060 / 1996 \text { que prevê alienação } \\
\text { de bens públicos na Vila Planalto }\end{array}$ & $\begin{array}{l}\text { O TJDFT julgo vício de iniciativa, } \\
\text { inconstitucionalidade formal e material, já que } \\
\text { aliena bens públicos sem o necessário procedimento } \\
\text { licitatório, privilegiando ilegalmente particulares em } \\
\text { detrimento de toda a população do DF. }\end{array}$ \\
\hline 9 & $\begin{array}{l}\text { Acórdão } \mathrm{N}^{\circ} \\
251593\end{array}$ & $21 / 06 / 2006$ & $\begin{array}{l}\text { Apelação Cível } \begin{array}{l}\text { Cautelar } \\
\text { exibição de documentos. }\end{array} \\
\text { de }\end{array}$ & $\begin{array}{l}\text { Extinção da causa, sem julgamento de mérito. } \\
\text { Moradores pediam recurso para não apresentar } \\
\text { documentos exigidos para fixação. }\end{array}$ \\
\hline 10 & $\begin{array}{l}\text { Acórdão } \mathrm{N}^{\circ} \\
308486\end{array}$ & $04 / 06 / 2008$ & $\begin{array}{l}\text { Apelação } \quad \text { Cível. } \quad \text { Julga } \\
\text { inexigibilidade das multas relativa à } \\
\text { infração NGB na Vila Planalto. }\end{array}$ & $\begin{array}{l}\text { Ratifica a remissão, pela Lei Distrital } \mathrm{N}^{\circ} 1.744 / 97, \\
\text { sobre as multas a imóveis localizados na Vila } \\
\text { Planalto relativas a infração ao Código de Obras e } \\
\text { Edificações de Brasília. }\end{array}$ \\
\hline 11 & $\begin{array}{l}\text { Acórdão } \mathrm{N}^{\circ} \\
313316\end{array}$ & $30 / 06 / 2008$ & $\begin{array}{l}\text { Apelação Cível. Nega apelação da } \\
\text { TERRACAP para cancelar } \\
\text { concessão de uso de filha de } \\
\text { pioneiro da Vila Planalto }\end{array}$ & $\begin{array}{l}\text { Ratifica a o direito à ocupação do imóvel na Vila } \\
\text { Planalto apesar de ter recebido uma concessão de } \\
\text { uso em Agua Claras. }\end{array}$ \\
\hline 12 & $\begin{array}{l}\text { Acórdão } \mathrm{N}^{\circ} \\
460430\end{array}$ & $27 / 10 / 2010$ & $\begin{array}{l}\text { Apelação Cível. Legitima o } \\
\text { cumprimento dos requisitos para } \\
\text { fixação de filho de pioneiro. }\end{array}$ & $\begin{array}{l}\text { Se condena ao DF a providencias o assentamento do } \\
\text { demandante, filho de pioneiro, em lote da Vila } \\
\text { Planalto. }\end{array}$ \\
\hline 13 & $\begin{array}{l}\text { Acórdão } \mathrm{N}^{\circ} \\
464990\end{array}$ & $17 / 11 / 2010$ & $\begin{array}{l}\text { Apelação Cível. Nega apelação de } \\
\text { filho de pioneiro da Vila que } \\
\text { recebeu lote em Agua Claras }\end{array}$ & $\begin{array}{l}\text { Mantem a sentença a favor da TERRACAP para } \\
\text { cancelar contrato de Concessão de Uso a filho de } \\
\text { pioneiro que cedeu seu direito de ocupação a } \\
\text { terceiro. }\end{array}$ \\
\hline 14 & $\begin{array}{l}\text { Documento } \\
\mathrm{N}^{\circ} \quad 103- \\
000.168\end{array}$ & 2011 & $\begin{array}{l}\text { Regularização dos lotes e alteração } \\
\text { do gabarito, e inclusão do setor } \\
\text { como área de interesse social. }\end{array}$ & $\begin{array}{l}\text { A Associação de Moradores da Vila Planalto } \\
\text { (AMVP) solicita a regularização fundiária e a } \\
\text { inclusão como área habitacional de interesse social } \\
\text { no PDOT. }\end{array}$ \\
\hline
\end{tabular}




\begin{tabular}{|c|c|c|c|c|}
\hline 15 & $\begin{array}{l}\text { Documento } \\
\mathrm{N}^{\mathrm{o}} \quad 103- \\
000.185\end{array}$ & 2011 & $\begin{array}{l}\text { Regularização dos lotes e alteração } \\
\text { do gabarito, e inclusão do setor } \\
\text { como área de interesse social. }\end{array}$ & $\begin{array}{l}\text { A Comissão Pró-Regularização Definitiva dos Lotes } \\
\text { da Vila Planalto solicita a regularização fundiária } \\
\text { com entrega das escrituras definitivas. }\end{array}$ \\
\hline 16 & $\begin{array}{l}\text { Documento } \\
\mathrm{N}^{\mathrm{o}} \quad 103- \\
000.188\end{array}$ & 2011 & $\begin{array}{l}\text { Regularização de áreas ocupadas } \\
\text { por famílias no Setor de Chácara da } \\
\text { Vila Planalto. }\end{array}$ & $\begin{array}{l}\text { A Associação dos Produtores da Vila Planalto } \\
\text { solicita a legalização da situação do setor de } \\
\text { Chácaras. }\end{array}$ \\
\hline 17 & $\begin{array}{l}\text { Acórdão } \quad \mathrm{N}^{\mathrm{o}} \\
583208\end{array}$ & $25 / 04 / 2012$ & $\begin{array}{l}\text { Apelação Cível. Nega provimento à } \\
\text { TERRACAP para licitar lote cedido } \\
\text { em Aguas Claras a filho de pioneiro } \\
\text { da Vila Planalto. }\end{array}$ & $\begin{array}{l}\text { Obrigada a TERRACAP a fazer contrato de } \\
\text { concessão de uso sobre imóvel para filho de } \\
\text { pioneiro que recebeu lote em Aguas Claras. }\end{array}$ \\
\hline 18 & $\begin{array}{l}\text { Acórdão } \quad \mathrm{N}^{\mathrm{o}} \\
587165\end{array}$ & $09 / 05 / 2012$ & $\begin{array}{l}\text { Apelação Cível. Nega apelação de } \\
\text { morador da Vila Planalto que pedia } \\
\text { outro imóvel. }\end{array}$ & $\begin{array}{l}\text { Nega provimento a morador do Ac. Pacheco } \\
\text { Fernandes que solicitava indemnização e um novo } \\
\text { lote por tiver o seu ocupada irregularmente por } \\
\text { vizinhos. }\end{array}$ \\
\hline 19 & $\begin{array}{l}\text { Acórdão } \mathrm{N}^{\mathrm{o}} \\
649905\end{array}$ & $30 / 01 / 2013$ & $\begin{array}{l}\text { Agravo de Instrumento. Anula ato } \\
\text { administrativo com ordem de } \\
\text { demolição de construção na Vila } \\
\text { Planalto. }\end{array}$ & $\begin{array}{l}\text { Determina que a AGEFIS se abstenha de demolir } \\
\text { construção localizada na Rua Nova, Lote } 40 \text { devido } \\
\text { ao avance das obras, mas impede continuidade ou } \\
\text { ocupação. A obra é responsabilidade de um } \\
\text { empreendedor que adquiriu o imóvel em } 2001 \text { e } \\
\text { tentaria destinar o imóvel para locação de quitinetes. } \\
\text { Custo da obra de } \mathrm{R} \$ 600 \text { mil. }\end{array}$ \\
\hline 20 & $\begin{array}{l}\text { Acórdão } \mathrm{N}^{\mathrm{o}} \\
680486\end{array}$ & $23 / 05 / 2013$ & $\begin{array}{l}\text { Agravo de Instrumento. Nega } \\
\text { provimento de MPDFT que tenta } \\
\text { impedir novas edificações na Vila } \\
\text { Planalto. }\end{array}$ & $\begin{array}{l}\text { O MPDFT alega que por ser área tombada as } \\
\text { irregularidades das ocupações no local causam dano } \\
\text { ao patrimônio requerendo interdição das obras. O } \\
\text { tribunal julgou os prejuízos genéricos e sem } \\
\text { comprovação suficiente. }\end{array}$ \\
\hline 21 & $\begin{array}{l}\text { Acórdão } \mathrm{N}^{\mathrm{o}} \\
688363\end{array}$ & $24 / 06 / 2013$ & $\begin{array}{l}\text { Embargos Infringentes Cíveis. } \\
\text { Reconhece concessão de direito real } \\
\text { de uso a residente da Vila Planalto }\end{array}$ & $\begin{array}{l}\text { Nega pedido da TERRACAP. Assegura a posse do } \\
\text { recorrente sobre o imóvel situado na Rua do } \\
\text { Alojamento Lote } 05 \text {, Acampamento Rabelo. }\end{array}$ \\
\hline 22 & $\begin{array}{l}\text { Acordão } \mathrm{N}^{\mathrm{o}} \\
700319\end{array}$ & $07 / 08 / 2013$ & $\begin{array}{l}\text { Agravo de Instrumento. Nega } \\
\text { recurso para evitar suspensão de } \\
\text { construção de edificação na Vila } \\
\text { Planalto. Ação promovida por } \\
\text { vizinho da obra alegando perda de } \\
\text { privacidade. }\end{array}$ & $\begin{array}{l}\text { Determina suspensão de qualquer obra e ocupação } \\
\text { na Rua } 02 \text {, Casa } 25 \text {, Acampamento Rabelo, onde se } \\
\text { constrói um prédio de } 2 \text { pavimentos destinado a } \\
\text { apartamento de lojas comerciais, sob pena de multa } \\
\text { diária no valor de } R \$ 1.000 \text {. }\end{array}$ \\
\hline 23 & $\begin{array}{l}\text { Acordão } N^{\circ} \\
760282\end{array}$ & $12 / 02 / 2014$ & $\begin{array}{l}\text { Ação Civil Pública. Nega apelação } \\
\text { do GDF contra TERRACAP. }\end{array}$ & $\begin{array}{l}\text { Nega pedido do GDF que recorre contra ação do } \\
\text { MPDFT que o obriga a apresentar cronograma para } \\
\text { revitalização do Conjunto Fazendinha na Vila } \\
\text { Planalto. }\end{array}$ \\
\hline 24 & $\begin{array}{l}\text { Acordão } \mathrm{N}^{\mathrm{o}} \\
769325\end{array}$ & $12 / 03 / 2014$ & $\begin{array}{l}\text { Apelação Cível. Nega provimento } \\
\text { contra ação do ASPV contra o GDF } \\
\text { solicitando regularização das } \\
\text { ocupações na Vila Planalto. }\end{array}$ & $\begin{array}{l}\text { Decreta improcedente pedido da Associação dos } \\
\text { Produtores da Vila Planalto (ASPV) solicitando a } \\
\text { regularização das ocupações clandestinas de seus } \\
\text { associados em área pública (Setor de Chácaras) da } \\
\text { Vila Planalto. }\end{array}$ \\
\hline 25 & $\begin{array}{l}\text { Acórdão } \mathrm{N}^{\circ} \\
811018 \\
\text { ADI } \\
2013.00 .2 \\
017328-8\end{array}$ & $24 / 06 / 2014$ & 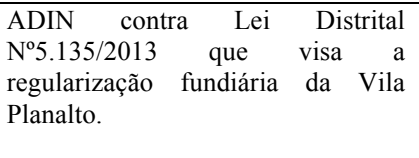 & $\begin{array}{l}\text { A ADI é julgada improcedente declarando a lei } \\
\text { formalmente constitucional. Permite a sem reparos } \\
\text { venda direta ou a doação de imóveis a ocupante dos } \\
\text { lotes objeto de regularização da Vila Planalto. }\end{array}$ \\
\hline
\end{tabular}




\section{Transcrições de entrevistas}

Entrevista 1: Duas irmãs funcionárias públicas, moradoras antigas. Praça Nelson Corso, feriado à tarde.

1. Você mora na Vila Planalto? Há quantos anos?

Há 25 anos e 19 anos

2. Onde você morou anteriormente?

Sou Cearense vim de Fortaleza direto para cá. Eu também sou de Fortaleza, mas do interior.

3. Você é proprietária, aluga ou mora com algum familiar?

Moramos no mesmo lote, esse lote foi cedido para resolver até hoje que não foi resolvido.

4. Além da sua casa, qual é o lugar que você mais frequenta dentro da Vila?

Aqui nesta vila, ah o Armazém do Geraldo para fazer compras. Tudo dia de manha e de tarde para fazer compras. E na Igreja também, católica, na Igrejinha, vamos pra missa, fui à missa hoje já voltei.

5. Tem alguma loja ou bar (armazém, padaria, lanchonete, etc.) dentro do bairro aonde você vá com frequência?

Não eu não gosto, só no Armazém do Geraldo pra fazer compras. Aqui é pra comprar as coisas do dia a dia, pra comprar pão, fruta, coisinha pouca, mesmo.

6. Como é seu cotidiano, seu dia a dia? Você poderia descrever as atividades que realiza durante um dia normal de segunda a sexta feira? Como é seu itinerário?

Meu dia é trabalhar no Ministério da Cidade, entro lá $1 \mathrm{hr}$ da tarde saio de lá $7 \mathrm{hrs}$ da noite, chegou a casa faço uma janta, e essa a vida, depois dentro de casa.

Eu trabalho aqui na Vila Planalto mesmo, trabalho em uma academia, aqui pertinho, vou a pé, em 5 ou 10 minutinhos estou lá. Chegou em casa depois pra fazer comida pro marido e os filhos, né.

7. E os dias domingos? Que você costuma fazer?

Vou a missa mesmo, às vezes vou no conjunto (Shopping Conjunto Nacional) dar uma volta.

8. A que lugares você gosta ir de passeio ou para se divertir, dentro ou fora da Vila?

E gente fica mais em casa, não sou muito de sair não. A gente não bebe não gosto muito e bagunça sabe. Às vezes vou lá na Água Mineral, quando não vou pro Clube né, o Clube Alexandrino, bem pertinho da vila.

9. Que é o que você mais gosta e ou que menos gosta da Vila Planalto?

Muito bar, muito bêbado, muita bagunça isso é ruim, vai muita gente. Nós mesmos lá em casa às vezes não dá nem pra dormir, moro com um bar justo em frente. E isso tem muito tempo já.

O melhor é que é pertinho de tudo né, isso é bom, pertinho de todo mundo.

10. Como é sua relação como os vizinhos?

Temos amigos, mas tem alguns que perturbam também, por causa da bebida, que liga o som alto, vai fazer o que.

11. Que pensa em relação a como era a Vila quando você chegou como ela é agora, e como você a imagina no futuro?

Ah... Mudou muito, aqui só era tudo barraquinho de madeira, tudo era barro, não tinha, nossa, não tinha casona assim, essas casas enormes ai. Tal vez há uns 15 anos atrás que mudou, mas foi pra melhor, melhorou mais o lugar. E só que está muito perigoso por causa das drogas né.

O futuro eu vejo bem, vai melhorar agora na Copa aqui, os restaurantes daqui vai lotar, sempre lota, precisa de mais banco aqui, mais banco porque tudo aqui é na rodoviária, pra lá.

12. Você está sabendo sobre o processo de regularização fundiária (entrega dos lotes)? Você pensa que quando recebam os títulos de domínios dos lotes podem acontecer mudanças na Vila ou com os residentes?

Sim, pros que tem lote aqui. É justo entregarem a documentação pras pessoas. Já venderam muito lote aqui, né, bastante, talvez ainda vá vender mais. Eu acho que não, vai ficar mais valorizado, mais ainda do que já é. As pessoas que estão aqui há tantos anos eles merecem receber toda a documentação, eles merecem mesmo.

Entrevista 2: Francisca Ferreira Araujo, Presidenta de a Associação Renascer dos Pioneiros da Vila Planalto, véspera de carnaval na sede da associação.

1. Você mora na Vila Planalto? Há quantos anos?

Moro aqui há muito tempo, há 52 anos mais o menos.

2. Onde você morou anteriormente?

Eu vim do Piauí, eu vim pra Taguatinga e depois fui pra Vila Amauri. Quando desapareceu, nós viemos para Vila Planalto.

3. Você é proprietária, aluga ou mora com algum familiar?

Eu moro num acampamento, Rua 1 casa 9, acampamento Pacheco Fernandes.

4. Além da sua casa, qual é o lugar que você mais frequenta dentro da Vila?

A Igreja Católica e a associação que sou presidente daqui, dos idosos. 
5. Tem alguma loja ou bar (armazém, padaria, lanchonete, etc.) dentro do bairro aonde você vá com frequência?

Ah... Eu sempre vou ao Geraldo. Porque eu conheci o Geraldo desde rapaz, toda a vida ele teve o armazém pra vender pra gente. Como é conhecido há muitos anos, desde 1957.

6. Como é seu cotidiano, seu dia a dia? Você poderia descrever as atividades que realiza durante um dia normal de segunda a sexta feira? Como é seu itinerário?

Ah, meu dia a dia é o seguinte: eu trabalhei muitos anos como costureira, trabalhei já para universidade, trabalhei para o GDF e agora fico mais em casa, porque eu tive um filho excepcional e ele precisa muito de meu apoio, e como não tenho ninguém, eu sou viúva né, então fiquei a disposição dele. Ai fico mais em casa durante a semana.

7. E os dias domingos? Que você costuma fazer?

Os dias domingos vou passear, vou pra igreja, saio pra passear com ele. Eu vou a missa as 8 hrs da manha, não gosto ir a noite que é muito obscuro.

8. A que lugares você gosta ir de passeio ou para se divertir, dentro ou fora da Vila?

Vou, vou pros pagodes a beber, vou lá onde tiver. Asa Norte..., onde tiver as batucas a gente vai.

9. Que é o que você mais gosta e ou que menos gosta da Vila Planalto?

O que eu gosto é de morar aqui, que é muito bom, maravilhoso, a primeira cidade aonde eu cheguei foi aqui, adora a Vila Planalto. Não tem essas coisas assim não, tudo daqui eu gosto.

10. Como é sua relação como os vizinhos?

É ótima, tenho uns vizinhos maravilhosos. Não frequento casa de vizinho, é mais aqui. Gosto de todos os vizinhos, mas não sou muito de andar em suas casas não, nem eles na minha.

11. Que pensa em relação a como era a Vila quando você chegou como ela é agora, e como você a imagina no futuro?

Quando eu cheguei era parado, não tinha muita coisa, era tudo funcionário, pião, que eles chamam. Ai fim de semana, a gente ia pra fazer os forrós nos acampamentos. Mas agora pra época que eu cheguei está melhor, já tem tudo, já tem diversão pras pessoas sair.

12. Você está sabendo sobre o processo de regularização fundiária (entrega dos lotes)? Você pensa que quando recebam os títulos de domínios dos lotes podem acontecer mudanças na Vila ou com os residentes?

Ai, sim tomara que entreguem né, nós estamos esperando. Vamos ver, é necessário. Nós temos só o provisório, já tá vencido há 25 anos. Eu acho que não vai mudar muito não, porque muitos pioneiros não existem mais, tem poucos pioneiros, mas filhos e netos de pioneiros têm. Muito filho, neto, bisnetos, mas eu não sei, de aqui pra lá. Muitos já venderam muitos... Agora o meu eu não vendo, é o lugar onde morei toda minha vida e é bem perto, antigamente morava na rua da caixa d'água. Tem muita gente vinda de fora, desde uns 30 anos ou 40 anos, que chegou muita gente. Mudou muito, já tem esgoto.

Entrevista 3: Novo residente, diplomata de intercambio do Moçambique. Feriado de carnaval, no bar Quiosque da Catarina (frente à Praça Nelson Corso).

1. Você mora na Vila Planalto? Há quantos anos?

Eu moro há poucos dias.

2. Onde você morou anteriormente?

Morava na Asa Sul, aqui é uma zona mais accessível em termos de dinheiro, e é um bairro mais vivo mais acolhedor, na Asa Sul as pessoas são... Cada um vive a sua vida na Asa Sul. Aqui as pessoas são mais próximas. Eu morava na SQS 111.

3. Você é proprietária, aluga ou mora com algum familiar?

Estou alugando um apartamento, uma kitchenette. Vim porque conheci um companheiro da faculdade que mora aqui.

4. Além da sua casa, qual é o lugar que você mais frequenta dentro da Vila?

Deram-me algumas indicações outros companheiros de Moçambique e já frequentava, mas nenhum lugar específico.

5. Como é seu cotidiano, seu dia a dia? Você poderia descrever as atividades que realiza durante um dia normal de segunda a sexta feira? Como é seu itinerário?

Meu dia a dia é como eu posso dizer, é da casa pra escola e da escola pra casa, do Itamaraty pra cá. Na Asa Sul todo dia pra mim era igual, enquanto aqui é do sereno. Estou aqui bebendo conversando com o pessoal, tem muito respeito. Não digo que lá na Asa Sul não é assim, só que lá cada um fica no seu canto, talvez por ser uma zona de pessoas que tem muito poder econômico. Mas já achei esse lugar maravilhoso.

6. E os dias domingos? Que você costuma fazer?

Pra mim é um dia também especial, que aproveito pra fazer... Organizar as coisas que não consigo organizar durante a semana. Sexta é sábado é mais de ir pra rua, domingo fico mais em casa. 
Entrevista 4: Novo residente, diplomata de intercambio de São Tomé e Príncipe, feriado de carnaval, bar Quiosque da Catarina (frente à Praça Nelson Corso).

1. Você mora na Vila Planalto? Há quantos anos?

Moro na Vila há um mês e três semanas.

2. Onde você morou anteriormente?

Eu sou de São Tomé e Príncipe, são duas pequenas ilhas perto do continente africano. Eu vim cá pra um intercambio, sou diplomata no meu país e vim cá pra um intercambio. Quando cheguei passei uns dias em Águas Claras, é bem diferente, pela comunicação social é bem diferente, não tem nada a ver.

3. Você é proprietária, aluga ou mora com algum familiar?

Dentro do acordo que fizemos com o Brasil na vinda, era que nós temos que encontrar nossa residência, caberá a nós encontrar um espaço onde residir, e um colega que cá vivia há uns anos, me conseguiu vir pra Vila Planalto, que ele diz que é uma comunidade de famílias, uma zona calma e tudo isso. Foi por isso que eu vim, encontrei uma residência, onde eu tenho um preço de aluguel moderado para mim e resolvi ficar. Alugamos o espaço.

4. Além da sua casa, qual é o lugar que você mais frequenta dentro da Vila?

Dentro da vila particularmente acostumo ir ao Mercado do Geraldo, alguns becos ai para beber umas cervejinhas, particularmente é isso, porque eu não conheço as pessoas nem nada. Vou à farmácia, coisas do dia a dia.

5. Tem alguma loja ou bar (armazém, padaria, lanchonete, etc.) dentro do bairro aonde você vá com frequência?

Eu vou ao Geraldo porque para mim é a referencia na Vila Planalto.

6. Como é seu cotidiano, seu dia a dia? Você poderia descrever as atividades que realiza durante um dia normal de segunda a sexta feira? Como é seu itinerário?

Meu dia a dia particularmente, e feito no Rio Branco no instituto, tenho aula lá umas 9hrs, saio de casa umas $8 \mathrm{hr}$. E regresso muitas vezes aproximadamente as $8 \mathrm{hr}$ da noite. Saio por ai para encontrar algo por ai perto, chegou em casa a tomar um banho, vejo a televisão e dormir. Pra o trabalho vou de ônibus, vou de taxi, isso varia. Circular a minha via principal é esta ai, por aqui na praça.

7. E os dias domingos? Que você costuma fazer?

Os dias domingos particularmente antes de conhecer essa mulher aqui pela qual me apaixonei, meu dia era feito dentro de casa, não saia. Agora esta vindo o colega e a gente sai, vou pra casa dela, o ficamos por aqui a beber umas cervejinhas. Mas hoje é o primeiro dia que a gente se senta tanto tempo.

8. A que lugares você gosta ir de passeio ou para se divertir, dentro ou fora da Vila?

A diversão pra mim é mais feita da base de sentar com eles a beber uma cerveja.

9. Como é sua relação como os vizinhos?

Não me faça pergunta difícil, mas eu vou lhe dizer, a minha opinião particular é que... Acho que as pessoas são um pouco conservadoras. Mas onde eu vivo, tem umas 12 habitações, conheço quase toda a vizinhança, mas não temos uma relação muito chegada e mais uma relação de cumprimento, de bom dia, boa noite, coisas pontuais. Na Vila com quem tenho uma relação mais chegada é com o dono do edifício onde eu estou. Fora dele tem um senhor que trabalha no Rio Branco e faz o café ai pra nós, são as únicas pessoas que conheço da vila. Fora disso não conheço ninguém.

10. Que pensa em relação a como era a Vila quando você chegou como ela é agora, e como você a imagina no futuro?

Com toda realidade e franqueza, eu sou um apreciador nato da televisão da comunicação social, ver a realidade do país com a questão do indicie de criminalidade e todo isso e com aquilo que eu vejo, comparado com a realidade de cá na Vila Planalto e um lugar espetacular, lugar de família, calmo, posso sair, circulo quando chego das aulas as 8-9 da noite, nunca me passou nada e espero não me passe nada. Mais pra mim em comparação com as outras zonas de Brasília ou de outras grandes cidades de Brasil, pra mim é um lugar de referencia e até que eu tava a comentar com o colega, assim que eu chegar em São Tomé e Príncipe, anualmente vem diplomatas de meu pais fazer intercambio, vou recomendar este bairro, sempre recomendar. Pra mim e isso, mas tem a ver com minha filosofia de vida. Essa questão de tranquilidade, paz, poder sentar um dia beber uma cervejinha ai, é muito bom. Estou gostando muito da Vila Planalto, é um paraíso pra mim. 
Entrevista 5: Residente antiga, aposentada, sentada na praça na saída da Igreja Nossa Senhora da Pompeia.

1. Você mora na Vila Planalto? Há quantos anos?

Moro aqui há 32 anos. No acampamento Rabelo.

2. Onde você morou anteriormente?

Eu morava em Taguatinga.

3. Você é proprietária, aluga ou mora com algum familiar?

Sou proprietária.

4. Além da sua casa, qual é o lugar que você mais frequenta dentro da Vila?

Aqui a Igreja, o posto de saúde, o colégio.

5. Tem alguma loja ou bar (armazém, padaria, lanchonete, etc.) dentro do bairro aonde você vá com frequência?

Tem sim, o Armazém do Geraldo. Vou lá porque eu gosto, conheço lá há muito tempo e lá é bom de fazer compras. É um encontro de amigos, o pessoal se encontra lá, principalmente do dia 10 ao dia 15 e quando se encontram os pioneiros mesmo.

6. Como é seu cotidiano, seu dia a dia? Você poderia descrever as atividades que realiza durante um dia normal de segunda a sexta feira? Como é seu itinerário?

Agora eu sou aposentada, de manha faço caminhada, faço academia, e minha vida e essa. Faço tudo aqui dentro da Vila.

7. E os dias domingos? Que você costuma fazer?

Dias domingos vou à casa dos filhos, passear onde os filhos. Tem uma que mora aqui e outra mora fora daqui, mora no Goiás.

8. A que lugares você gosta ir de passeio ou para se divertir, dentro ou fora da Vila?

Gosto muito de ir ao Teatro Nacional, gosto muito do teatro.

9. Que é o que você mais gosta e ou que menos gosta da Vila Planalto?

Olha praticamente gosto de tudo, é um lugar muito bom a Vila Planalto. O que eu menos gosto e da violência, violência assim sobre drogas, coisa assim que eu não gosto. Se não fosse isso seria um lugar excelente. Às vezes vejo algumas coisas que a gente fica um pouco triste, né, que não gostaria de ver.

10. Como é sua relação como os vizinhos?

Graças a deus é boa. Brasília não como uma cidade do interior, a vida é muito corrida. Mas me dou bem com todos.

11. Que pensa em relação a como era a Vila quando você chegou como ela é agora, e como você a imagina no futuro?

Mudou muito, pra melhor. A Ilha do Lago (condomínio de luxo na beira do Lago Paranoá), uma cidade nova, lugares muito bacana, esses hotéis novos na beira do lago, quero dizer que evolui bastante, né. Aqui dentro já mudou bastante, muita gente já foi embora, as pessoas nova pra mim é tudo gente bacana, mas a vida deles é um pouco diferente porque a vida deles é muito corrida né.

12. Você está sabendo sobre o processo de regularização fundiária (entrega dos lotes)? Você pensa que quando recebam os títulos de domínios dos lotes podem acontecer mudanças na Vila ou com os residentes?

Eu vejo o povo falar, mas diretamente nunca participei de nenhuma reunião, é meu esposo que vai. Acho que vai trazer mudanças pra melhor, com os documentos fica muito melhor. Já venderam muito e continua vendendo, não para de vender não, mas é pra melhor né, porque valoriza mais os imóveis. Fica bem melhor, fica mais caro como se disse, muita gente vende e vai embora, mas eu já não penso de vender o meu não, eu gosto muito daqui.

Entrevista 6: Filho de pioneiro, carroceiro. Na saída do Armazém do Geraldo.

1. Você mora na Vila Planalto? Há quantos anos?

Eu mora há 30. Sou filho de pioneiro. Mora na Rua 2, DFL.

2. Onde você morou anteriormente?

Morava na Nacional, Setor de embaixadas, bem ali, onde é o setor de embaixadas norte.

3. Você é proprietária, aluga ou mora com algum familiar?

Mora na minha mãe, ela que é a dona. Mas eu sou casado e mora do lado com minha esposa. Tenho uma casa do lado.

4. Além da sua casa, qual é o lugar que você mais frequenta dentro da Vila?

Aqui dentro da vila, o mercado mesmo, aqui no Geraldo mesmo.

5. Tem alguma loja ou bar (armazém, padaria, lanchonete, etc.) dentro do bairro aonde você vá com frequência?

Eu venho aqui, porque aqui as coisas são mais arrumadas. Compro há muito tempo aqui. 
6. Como é seu cotidiano, seu dia a dia? Você poderia descrever as atividades que realiza durante um dia normal de segunda a sexta feira? Como é seu itinerário?

Eu trabalho sou carroceiro. Trabalho com retirada de entulho aqui.

7. E os dias domingos? Que você costuma fazer?

Vou ao clube, vou na Torre. Vou ao clube Alexandrino.

8. A que lugares você gosta ir de passeio ou para se divertir, dentro ou fora da Vila?

Gosto de Caldas Novas.

9. Que é o que você mais gosta e ou que menos gosta da Vila Planalto?

Dar uma corrida, fazer umas corridas aqui, e fazer malhação ali no circuito. Não gosto do Setor de Chácaras, porque só tem pilantra lá. Eu queria fazer uma vaia lá na época e eles não deixaram, levar meu cavalo. Eles invadem lá, e ai a gente tentou fazer um negócio e eles se meteu no meio ai não deixou. Alguns tem dinheiro e alguns não, a maioria é invadido, compraram lá, o cara que morou há muito tempo já vendeu.

10. Como é sua relação como os vizinhos?

Beleza tem amigos aqui, bem conhecidos aqui. Tem mais um irmão que mora lá embaixo.

11. Que pensa em relação a como era a Vila quando você chegou como ela é agora, e como você a imagina no futuro?

Quando eu cheguei naquela época era melhor do que hoje. Quando eu cheguei era só barraco, o pessoal não tinha nada, só diversão e os amigos. Hoje já ta diferente a vila, hoje tá muita criminalidade, o pessoal mata muito, o droga acabou com essa vila. A Vila mudou demais, a vila era boa, agora a vila está perigosa, antes era tranquilo. Muitos aqui venderam o lote, muito mesmo, mas quem chegou é tranquilo, morador é tranquilo. Não comparte muitos com os mais antigos, não.

12. Você está sabendo sobre o processo de regularização fundiária (entrega dos lotes)? Você pensa que quando recebam os títulos de domínios dos lotes podem acontecer mudanças na Vila ou com os residentes?

Só promessa, isso ai já vem prometendo há vários anos. Falaram que ia dar, que isso aqui. Acho que vai começar a vender, claro. Porque o pessoal vai vender ainda mais caro, já vende caro, né, ai com escritura já estou vendo, mais caro ainda, vai dar. Pode piorar o bairro, vai ter gente que vai comprar e pode aparecer gente que não conhecer. Pode mudar porque se todo mundo vender, já não vai ser mais a Vila Planalto, só morador novo.

Entrevista 7: Funcionário do Armazém do Geraldo no mesmo armazém.

1. Você mora na Vila Planalto? Há quantos anos?

Há uns 10 anos. Moro n acampamento Rabelo.

2. Onde você morou anteriormente?

Morava no Piauí, vim direto pra vila.

3. Você é proprietária, aluga ou mora com algum familiar?

Mora de aluguel com alguns familiares, em uma casinha.

4. Além da sua casa, qual é o lugar que você mais frequenta dentro da Vila?

O Armazém do Geraldo, o mercado. Eu trabalho aqui há 8 anos.

5. Tem alguma loja ou bar (armazém, padaria, lanchonete, etc.) dentro do bairro aonde você vá com frequência?

A maioria das compras eu faço aqui também.

6. Como é seu cotidiano, seu dia a dia? Você poderia descrever as atividades que realiza durante um dia normal de segunda a sexta feira? Como é seu itinerário?

Casa, armazém, armazém, casa só. Aqui à noite às vezes saio, tomas uma, às vezes uma cervejinha geladinha.

7. E os dias domingos? Que você costuma fazer?

Domingo, já saio, vou pra algumas cidades do entorno, vou pro Paranoá, essas coisas assim, jogar um futebolzinho e isso.

8. A que lugares você gosta ir de passeio ou para se divertir, dentro ou fora da Vila?

Eu prefiro dentro da vila, porque aqui é mais tranquilo. Também o Lago Paranoá, vou na orla.

9. Que é o que você mais gosta e ou que menos gosta da Vila Planalto?

10. Como é sua relação como os vizinhos?

É ótima, minha família inteira mora aqui também, em outro lote.

11. Que pensa em relação a como era a Vila quando você chegou como ela é agora, e como você a imagina no futuro?

Já mudou muito, o exemplo melhor é essa praçinha ai, já reformou já, quando cheguei aqui nem isso tinha direito. Deu uma melhoria também, em alguns lugares. Aqui melhorou um bocado já. Agora as pessoas já mudou muito! Foram embora muitas pessoas já. De aqui há uns 10 anos que saíram muita gente, 
principalmente nesses últimos 2 anos que tem aparecido mais gente nova aqui. Acho que tudo é normal, também a cidade ajuda a ter uma convivência ainda assim.

12. Você está sabendo sobre o processo de regularização fundiária (entrega dos lotes)? Você pensa que quando recebam os títulos de domínios dos lotes podem acontecer mudanças na Vila ou com os residentes?

A gente já ouve muito falar, só que... Que vão entregar que vão entregar. Nos últimos anos tem falado mais, mas até agora acho difícil sair. Eu creio que as pessoas vão começar a vender, e acho que não vai ser melhor não, acho que vai ser pra pior. Se houver mudança aqui, se algum liberar mesmo, todo mundo comenta muito, se chegar liberar é mais fácil os grandes usar muitas pessoas e comprar aqui e formar um condomínio. Exemplo Águas Lindas, foi um dos lugares que mais mudou, receberam as escrituras e o pessoal grande começou a comprar e mal hoje em dia é só prédio. Aqui também eu temo muito de acontecer isso.

Entrevista 8: Novo residente, estudante e funcionário do Armazém do Geraldo, no armazém.

1. Você mora na Vila Planalto? Há quantos anos?

Um mês.

2. Onde você morou anteriormente?

Em Fortaleza, vim diretamente pra Vila. Estudava lá e fui convocado para trabalhar na Copa (mundial de futebol) em Brasília né, ai eu vim pra cá. Tem um tio por aqui. Mas eu sou de aqui, nasci aqui, só que minha famílias é Cearense, por isso eu fui pra lá.

3. Você é proprietária, aluga ou mora com algum familiar?

Eu moro sozinho, estou alugando uma suíte que tem três espaços, um banheiro, um quarto e a sala de estar. Na Rua 5.

4. Tem alguma loja ou bar (armazém, padaria, lanchonete, etc.) dentro do bairro aonde você vá com frequência?

Aqui no Armazém de Geraldo. Porque eu gosto, aqui você tem variedades, variedades tanto de produtos como de preços também. Tem o barzinho "praças" e o Piauí.

5. Como é seu cotidiano, seu dia a dia? Você poderia descrever as atividades que realiza durante um dia normal de segunda a sexta feira? Como é seu itinerário?

Movimentadísimo, porque já começou o treinamento da Copa, ai eu trabalho, saio $2 \mathrm{hrs}$ da tarde, vou em casa, praticamente fico em casa $1 \mathrm{hr}$ de 3 as 4, pego um ônibus e vou pra faculdade. Da faculdade vou pro treinamento da Copa, ai às vezes chegou $1 \mathrm{hr}$ da manha, meia noite, por ai, isso é de Segunda a Sexta, Sábado não vou pra faculdade ai fico mais em casa, mas também faço os trabalhos em casa.

6. E os dias domingos? Que você costuma fazer?

Domingo eu procuro sair, durante a semana já tenho a semana muito movimentada, então ou Sábado ou Domingo eu procuro sair, dou uma caminhada ou ler um livro, sair com os amigos, ir pra uma balada.

7. A que lugares você gosta ir de passeio ou para se divertir, dentro ou fora da Vila?

A Esplanada sou apaixonado pela Esplanada dos Ministérios, pra tirar foto pra passear, fazer piquenique, pra sair, caminhar também.

8. Que é o que você mais gosta e ou que menos gosta da Vila Planalto?

As pessoas, as pessoas são muito bem educadas, as pessoas são hospitaleiras, atenciosas. E também você aqui faz amizade rapidinho. É diferente de outros lugares de Brasília, de Fortaleza, as pessoas não falam com você, não falam bom dia, nem boa noite. Aqui não as pessoas falam com você, conversam com você, brincam com você, então até às vezes eu estranho. O que eu menos gosto, é muito parado, não tem muito movimento, não tem uma pista de skate, não tem uma dança, entendeu, é muito parado.

9. Você está sabendo sobre o processo de regularização fundiária (entrega dos lotes)? Você pensa que quando recebam os títulos de domínios dos lotes podem acontecer mudanças na Vila ou com os residentes?

Já ouvi falar, mas estou por fora do assunto. Acredito que deve trazer mais uma organização pra vila, porque as pessoas vão ficar com o documento, ai vai trazer mais organização pra vila, pras pessoas que moram aqui, pessoas que viram a vila nascer, acredito que vai trazer organização e segurança também.

Entrevista 9: Morador antigo, funcionário de uma farmácia na Vila. Em uma rua próxima à Praça da Rabelo.

1. Você mora na Vila Planalto? Há quantos anos?

Há 38 anos. Cheguei em 1976.

2. Onde você morou anteriormente?

No Nordeste, Ceará. Vim diretamente pra vila, vim com meus avos.

3. Você é proprietária, aluga ou mora com algum familiar?

Moro sozinho, sou agregado à empresa em que eu trabalho.

4. Além da sua casa, qual é o lugar que você mais frequenta dentro da Vila?

Só a igreja católica, os armazém pra fazer as compras e minha casa de volta. 
5. Tem alguma loja ou bar (armazém, padaria, lanchonete, etc.) dentro do bairro aonde você vá com frequência?

Armazém do Geraldo o armazém MM. Vou no Geraldo, pelo tempo, quando estou com pressa vou lá que é mais rápido, quando tenho menos tempo vou no outro.

6. Como é seu cotidiano, seu dia a dia? Você poderia descrever as atividades que realiza durante um dia normal de segunda a sexta feira? Como é seu itinerário?

Sempre trabalho pra minha casa.

7. E os dias domingos? Que você costuma fazer?

Os domingos estou de plantão no serviço e a noite vou na igreja.

8. A que lugares você gosta ir de passeio ou para se divertir, dentro ou fora da Vila?

Sempre no Shopping do Conjunto Nacional

9. Como é sua relação como os vizinhos?

São todos meus amigos, todos beleza, todo bacana.

10. Que pensa em relação a como era a Vila quando você chegou como ela é agora, e como você a imagina no futuro?

Mudou muito né, mudou muito. Antigamente era só barraco de madeira, telhado de Zinco, matagal, sem asfalto, estrada de chão, hoje esta mudando tudo, organizando tudo. Ta vindo muita gente de fora. Essas pessoas que estão vindo de fora a maioria tá comprando lote daqueles que ganharam, pioneiros que não tiveram condições de construir estão vendendo e estão saído fora e os que compraram estão construindo. Eles tem uma renda maior, vem porque é perto do centro.

11. Você está sabendo sobre o processo de regularização fundiária (entrega dos lotes)? Você pensa que quando recebam os títulos de domínios dos lotes podem acontecer mudanças na Vila ou com os residentes?

Só promessas, por enquanto só promessa, essa promessa tem já há uns 30 anos essa promessa. Provável que não traga mudanças. Talvez as pessoas vendam, faz sentido pra quem está aqui há muito tempo, pra que vendeu, e quem comprou já esta sendo proprietário, quando sair a escritura vão querer um valor a mais, vai valorizar mais.

Entrevista 10: Funcionário público, na rua perto da Praça da Rabelo.

1. Você mora na Vila Planalto? Há quantos anos?

15 anos.

2. Onde você morou anteriormente?

$\mathrm{Na} 403$ Sul. Quando vim morar na vila, a vila ainda era uma cidade pequena, mas o menos uma vila de barracos de madeira e também muito tranquila, as pessoas deixavam suas roupas penduradas na varanda, ficavam sentadas nas calçadas... Era uma cidade do interior, mas no centro da capital.

3. Você é proprietária, aluga ou mora com algum familiar?

Sou proprietário.

4. Além da sua casa, qual é o lugar que você mais frequenta dentro da Vila?

Os restaurantes, Sertão e Mac que é de um amigo meu, e também é mais amplo mais aberto, olhando para o lago. O Fogão de Pedras e o Fogo de Lenha lá encimam, tem vários aqui que eu frequento.

5. Tem alguma loja ou bar (armazém, padaria, lanchonete, etc.) dentro do bairro aonde você vá com frequência?

De construção aqui na Pecol, o Armazém do Geraldo, que mais pratico e mais perto de casa aqui né.

6. Como é seu cotidiano, seu dia a dia? Você poderia descrever as atividades que realiza durante um dia normal de segunda a sexta feira? Como é seu itinerário?

No trabalho, trabalho na Advocacia Geral da União e sou jornalista, trabalho no Jornal de Brasília. Vou de carro.

7. E os dias domingos? Que você costuma fazer?

Vou para o Clube e escrever, escrevo minhas colunas da Revista Evidencia.

8. Que é o que você mais gosta e ou que menos gosta da Vila Planalto?

O que mais gosto e o lazer, né. Das coisas que mais gosto é escrever, que faz parte de meu cotidiano. A vila me dá tranquilidade pra escrever, porque é uma cidade ainda relativamente sem muito barulho e ma dá essa tranquilidade pra escrever, minha mira pro Lago e também tem essa visão que é muito boa, a cidade tem aumentado muito, mas ainda tem essa tranquilidade.

9. Que pensa em relação a como era a Vila quando você chegou como ela é agora, e como você a imagina no futuro?

Não, o que eu tenho visto é o seguinte: a cidade, ela não pode crescer né, expandir as fronteiras, mas mudou, mudou muito, mudou radicalmente, era barraco de madeira, as casas eram de madeira, porque isto aqui era das construtoras, Pacheco Fernandes, Tamboril, Rabelo e DFL. E mudou rapidamente, em questão de 4 a 5 anos a cidade se transformou, hoje,... Ela se transformou para melhor, ficou mais bonito. As pessoas que 
estão vindo morar, são pessoas boas que estão vindo morar aqui, tem um padrão de vida melhor, mas alguns que ainda tem ai, que tem casinhas ou barracosinhos nos fundos que alugam pra pessoas que estão vindo de fora, das cidades satélites e quando chega aqui eles ainda praticam roubo, essas pequenas coisas, fazem da cidade um ponto para roubar. Mas de aqui mesmo, da vila, não existe pessoas que tenham grande marginalidade, são pessoas que vem de fora. Agora as pessoas que tem comprado aqui, que tem beneficiado a vila são muito boas, foi pra melhor e a vila tá bem melhor.

10. Você está sabendo sobre o processo de regularização fundiária (entrega dos lotes)? Você pensa que quando recebam os títulos de domínios dos lotes podem acontecer mudanças na Vila ou com os residentes?

Estou, mas já passou já se passaram muitos programas desse tipo e nenhum na verdade foi levado avante. Já cansei de entregar documentação de presenciar o povo lá... Olha daqui a 15 dias saem as escrituras, mas até hoje não saíram. Eu já dei meu documento lá da minha casa, nossos amigos daqui também já deram... Sai hoje, sai amanha, sai daqui a um ano, mas até agora nada. Quando sair se sair, ainda será para a pessoa pagar, e eu que paguei pelo terreno, vou ter que pagar de novo. A gente espera que seja realmente um pagamento de forma fundiária mesmo, só do solo e com valores que a gente possa arcar a pagar, porque a Terracap cobra o metro de terra muito caro aqui, nessa situação aqui no Plano Piloto e os moradores já compraram, já pagaram então os acordos que foram feito nos documentos é que a gente vai pagar só o valor fundiário um pouco menor e que será financiado de aqui a 40, 60 meses de acordo com cada um.

$\mathrm{Eu}$ acho que não vai vender muita gente não, até porque quem tá aqui veio para morar num lugar melhor, a gente gosta de aqui e alguns que venderem, senão venderam ainda, são pessoas que não tem condições mesmo de fazer, seriam moradores mais antigos, alguns que ainda tem algum fundinho, coisa ai, mas não acredito que isso vai virar uma imobiliária, uma especulação não. Agora, evidentemente que os valores devem aumentar, porque com os documentos normalmente aumenta. Pelo que eu tenho visto as pessoas não estão muito preocupadas com as escrituras não. Se você põe uma placa em uma casa dessas pra vender, asseguro que ela será vendida pelo preço que o cara pede. As pessoas não querem nem saber se tem escritura, o que elas querem é comodidade, a posição estratégica, não tem engarrafamento aqui como no plano, aqui é melhor que a 405 Sul ou a 406 Norte onde já tem muito mais fluxos de engarrafamento, aqui a gente ainda consegue comodidade pra rodoviária, setor de trabalho Sul, Norte, sem muito percalço dos engarrafamentos. 


\section{Pesquisa etnográfica na Vila Planalto.}

\section{Quinta-feira 23 de Outubro de 2014.}

A ideia inicial era realizar uma caminhada aleatória pelo bairro, mas lembrei de um lote em construção com um grande buraco (que tinha visto no sábado anterior), presumivelmente para a construção de estacionamentos subterrâneos, fato que seria inédito no bairro. Decidi ir olhar o lote de novo, para tirar fotos, conversar com os encarregados da obra e saber qual era o projeto para esse lugar.

Sai de casa às $11.30 \mathrm{~h}$, fui caminhando pela Rua 1 até o Conjunto Fazendinha que fica em frente ao lote em questão. Ao chegar na esquina do lote, me deparei com uma cena que chamou minha atenção. $\mathrm{Na}$ casa ao lado da construção estavam agentes da Policia Civil-Segurança Pública interditando a obra porque as paredes laterais da escavação começaram a desabar por causa das chuvas do dia anterior, provocando a caída de um muro do vizinho. As chuvas e a falta de medidas de mitigação da obra, gerou insegurança nos moradores, fato pelo qual foi acionada a segurança pública.

Observei a situação a distância e sentei num ponto de ônibus, na calçada em frente às casas e aguardei enquanto as pessoas da obra, os vizinhos afetados e a guarda civil conversavam sobre a situação. Tirei algumas fotos e fiquei conversando com um senhor que estava sentado do meu lado sobre os motivos para a guarda civil estar ai. Ao mesmo tempo em que a guarda civil interditava a obra, os operários e maquinaria pesada (retro escavadora) continuavam trabalhando no lote como se nada acontecesse.

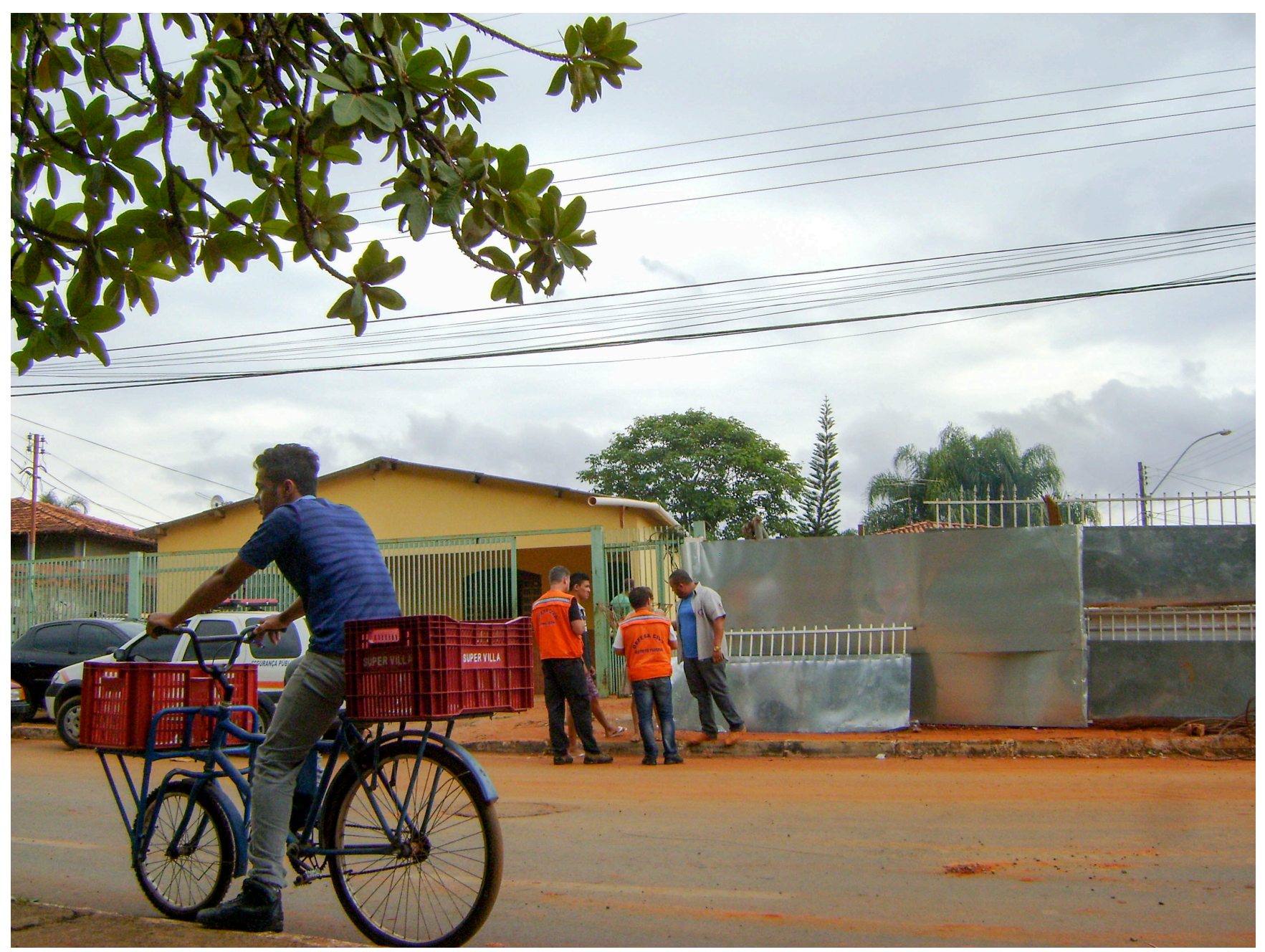


Com o tempo mais vizinhos começaram a se aproximar do lugar, curiosos pelas presença da policia e ficavam no limite do lote observando a grande escavação. Aproveitei para me aproximar e tirar fotos mais de perto. Um rapaz que morava na casa afetada percebeu que estava tirando fotos e me perguntou de onde era, eu lhe comentei que era estudante e que estava pesquisando sobre o bairro quando me encontrei com aquela situação e perguntei o que acontecia. Ele me comentou que tinham acionado a Policia Civil devido a um derrube de um muro da casa deles. Perguntei se podia tirar fotos, ele falou que sim e que se quiser podia entrar no quintal e tirar fotos desde dentro. Logo disso, falei com a mãe do rapaz e gravei uma entrevista com ela, que me contou mais detalhes do ocorrido. Ela mencionou que moravam 13 pessoas no lote, na casa principal morava sua mãe, Dona Francisca, e na casa dos fundos morava ela e sua família. Ela comentou que a empresa GNT (responsável pela obra) tinha conversado com eles antes de começar os trabalhos, e que tinham autorizado a demolir o muro divisório do lote, já que a empresa se comprometeu a reconstruir com uma melhor qualidade e altura. Ela negou ter recebido dinheiro algum como compensação. Quando perguntei se a obra trazia algum beneficio para eles, ela diz que sim, que valorizaria o lote deles por morar do lado de um prédio, que seria só de 2 andares e que teria estacionamento no subsolo, mas desconhecia o projeto.

A família dela tinha chegado há 24 anos na Vila Planalto, e que o dono do lote vizinho tinha morrido e os filhos decidiram vender. Ela diz não conhecer pessoalmente a nova dona, mas que parecia que ela morava nos Estados Unidos. Apesar do desgosto provocado pela obra, ela confiava em que a construtora GNT consertaria o dano, estabilizaria o terreno e que logo continuariam com a obra. Continue conversando informalmente como o marido da senhora, mas quando chegou a Dona Francisca me apresentei e perguntei se podia fazer umas perguntas, ela falou que sim, mas quando perguntei se podia registrar a entrevista, falou que se estavam queimando suas panelas, saiu correndo e fechou a porta da casa. O senhor que estava ali, levantou os ombros sem saber o que fazer, eu pedi desculpa falei que não queria perturbar e me despedi, saí do quintal e foi para a rua, tentar conversar com alguém da empresa. 


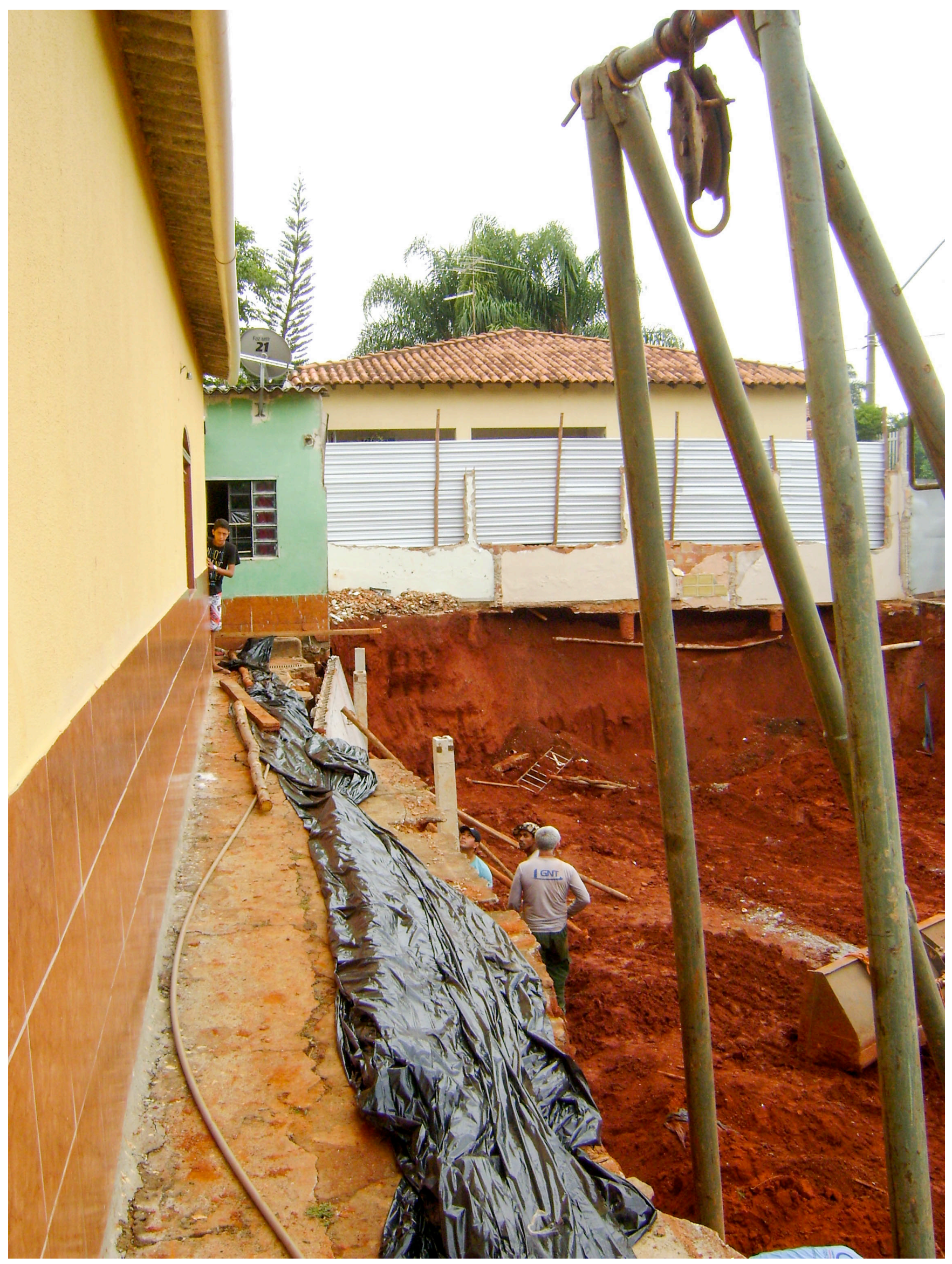


Os funcionários não quiseram dar informação e falaram para esperar o engenheiro que viria às $15 \mathrm{~h}$. Os funcionário da Defesa Civil, disseram que o engenheiro deles encontraria com o engenheiro da empresa, e que a obra poderia continuar sem problema depois de estabilizar o terreno e construírem as contenções laterais.

Voltei ás $15 \mathrm{~h}$ para entrevistar o engenheiro mas ele nunca apareceu.

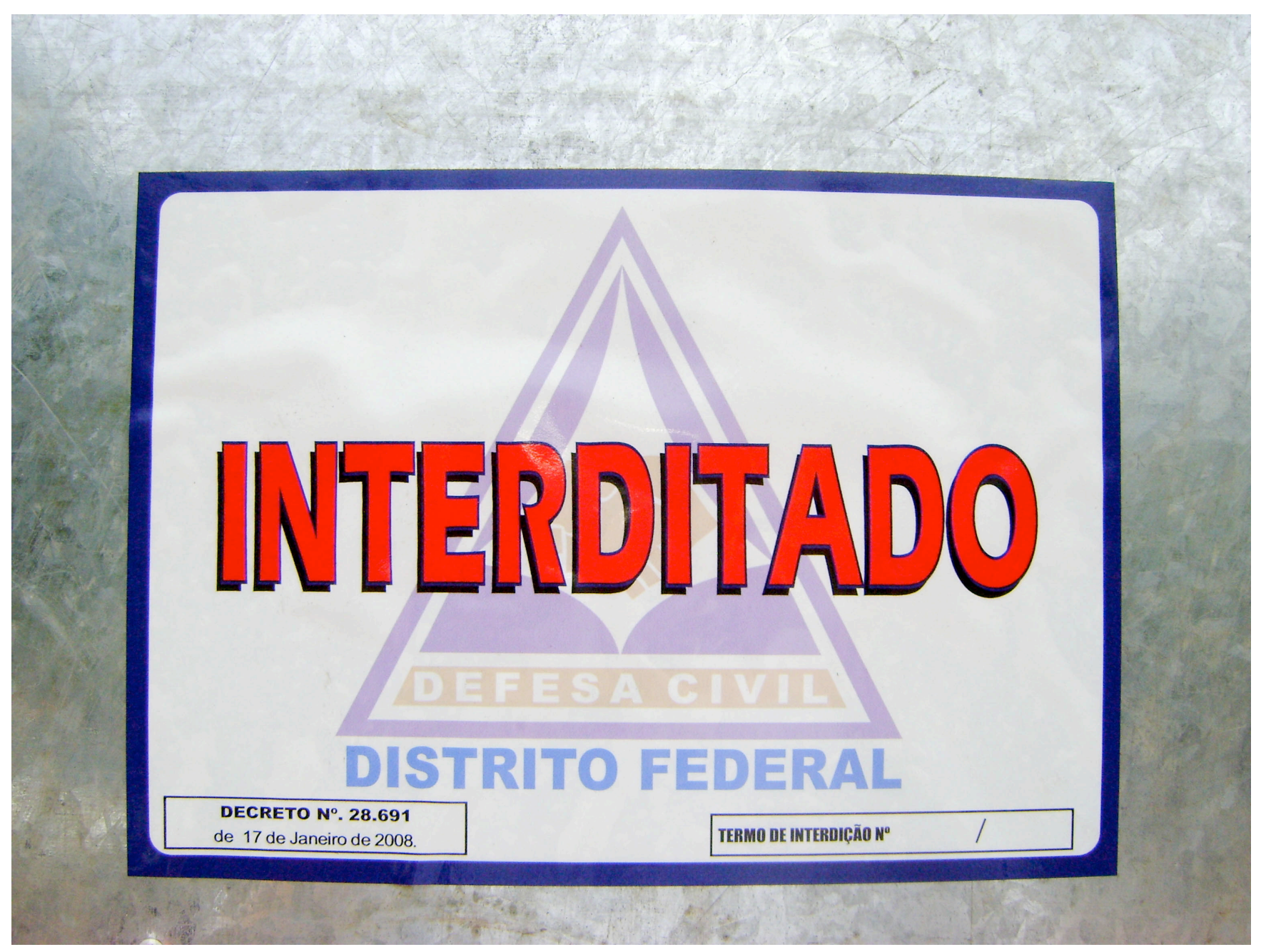




\section{Transcrição entrevista a Francessi, filha de dona Francisca, moradora da casa afetada.}

- $\quad$ A senhora mora aqui?

Sim, moro nos fundos.

Há quantos anos?

Desde 24 anos.

- $\quad$ É a casa de sua mãe?

Isso, é a casa da minha mãe.

Quando começou a obra aqui do lado?

Olha, deve ter uns quatro ou cinco meses.

E quando começou a dar problema para vcs?

Na verdade foi só agora, por causa dessa chuva. Mas qualquer problemas eles vão atrais. Quando houve esse problema ai, deixou a gente muito preocupada porque o pilar de lá do fundo ficou fora.

- $\quad$ Vcs sentiram a parede cair?

Não, não, o que caiu foi o muro, de lá do lado da minha parede.

A empresa, quando começaram a obra, falaram com vcs?

Falou, conversaram.

A senhora conhece o projeto?

Não o projeto eles não apresentou, conversamos de boca.

- $\quad$ Mas, eles vão construir o que?

Eles vão fazer um prédio, ali vai ter uma garagem subterrânea.

E de quantos andares vai ser o prédio?

Ah, se não me engano vai ser de 2 andares só, o primeiro e o segundo.

- $\quad$ A senhora se incomoda de ter prédio do lado?

Não, não me incomodo não.

Mas agora gerou um prejuízo?

É, mas é assim, qualquer coisa eles falaram que eles que arcam. Eu me preocupo com a gente né, que vai arcar são eles.

Quantas pessoas moram na casa?

Moram 7 pessoas lá no fundo, que é eu com meus filhos e meu marido, e aqui mora minha mãe com meus irmãos, são 13 pessoas em total.

- $\quad$ E sua mãe mora aqui a quanto tempo?

O mesmo tempo que eu, chegamos aqui há 24 anos.

- $\quad$ Vc acha que pode trazer algum beneficio a construção do prédio?

Eh..., eu creio assim, que vai ficar mais valorizado, com o prédio deles ai, aqui vai ficar bem valorizado. 
- $\quad$ Vc acha que isso é bom pra vcs?

É ótimo. Vai ficar mais valorizado nosso lote aqui.

- $\quad$ Isso porque vcs tem intenção de vender o lote ou a casa?

Futuramente minha mãe fala, mas na verdade agora não.

- $\quad$ Mas ela quer sair do bairro?

Agora agora não. Ela fala que vende mas na verdade vai terminar nem vendendo. Que na verdade eles estão dando a escritura né. Aqui não é bem legalizado assim. Tá começando a entregar, tem muitas pessoas que tem já a escritura na mão, porque estão entregando por etapa. Ai sim que vai ficar mais valorizado.

- $\quad$ E vcs como filhos, venderiam o lote no futuro?

Ah... ai com os irmãos tem que combinar né.

E vc que mora aqui, gostaria de ficar?

Eu não quero sair de aqui não na verdade. Costumei aqui.

- $\quad$ Vc se incomoda de que a obra continue? Vc se sente segura?

Não, pode continuar. Eles arrumando ai, vai dar segurança pra gente. O engenheiro está vindo ai, vai dar a palavra final. Que na verdade minha não intrincou nem nada, o problema foi lá nos fundos.

- $\quad$ Ves acionaram a Defesa Civil?

Foi. Sim, diretamente lá.

Que existia aqui do lado antes?

Tinha uma casa, igual a nossa aqui, mesmo modelo. Ai na verdade é que a moça que morava com a vizinha faleceu e os filhos venderam né. Era uma casa na frente e um barraco nos fundos, igual aqui.

- $\quad$ E os filhos?

Ficaram por aqui mesmo, porque cada um já tinha sua casa. Eram dois irmãos, venderam e cada um ficou com sua parte, pronto. Mas moram por aqui, eles tem as casas deles.

- $\quad$ E vc sabe quem comprou o lote?

Na verdade, eu só sei assim, a dona mesmo não conheço, conheço o irmão dela. Ele que cuida, ele não mora na Vila não. Na verdade, ela não mora aqui na Vila não, ela mora nos Estados Unidos.

- $\quad$ O limite do lote chegava aonde?

Chegava aqui nessa grade até a parede.

- $\quad$ Vc se assusta de ver o terreno assim?

Me assustei foi no dia da chuva, o dia da chuva aqui oh, as telhas caíram, derrubou o muro de lá desabou. Eu falei, meu deus, a parede vai cair com a gente toda aqui. E a chuva não foi nem tão forte assim viu.

E aquele cano de agua, eles que fizeram de novo a instalação?

É sim. 